Fall 1972

\title{
1972 Miracle Yearbook
}

\section{Cedarville College}

Follow this and additional works at: https://digitalcommons.cedarville.edu/yearbooks

Part of the Higher Education Commons, Organizational Communication Commons, and the Public Relations and Advertising Commons

\section{Recommended Citation}

Cedarville College, "1972 Miracle Yearbook" (1972). Yearbooks. 4.

https://digitalcommons.cedarville.edu/yearbooks/4

This Book is brought to you for free and open access by DigitalCommons@Cedarville, a service of the Centennial Library. It has been accepted for inclusion in Yearbooks by an authorized administrator of DigitalCommons@Cedarville. For more information, please contact digitalcommons@cedarville.edu. 



\section{,}





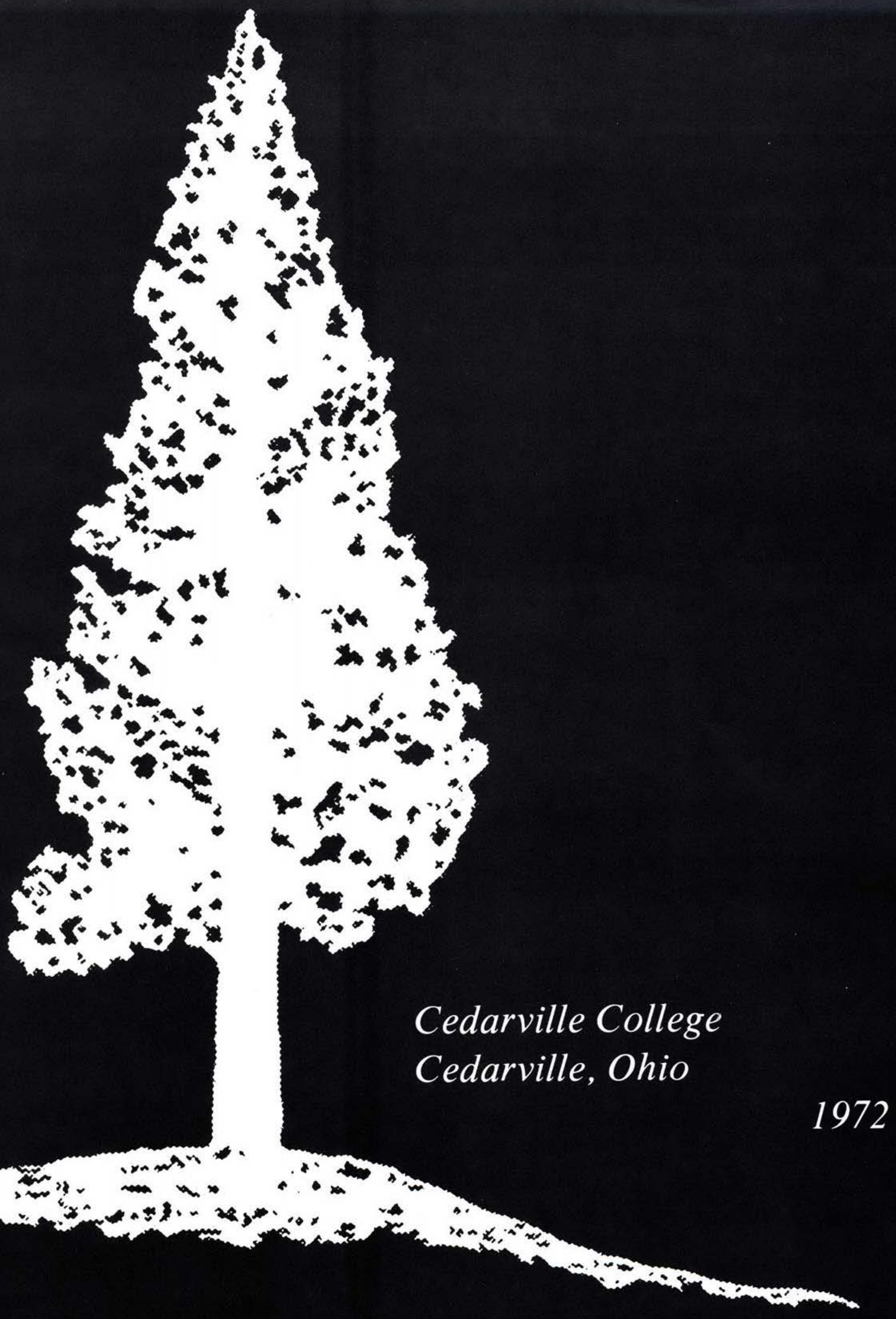


$>$

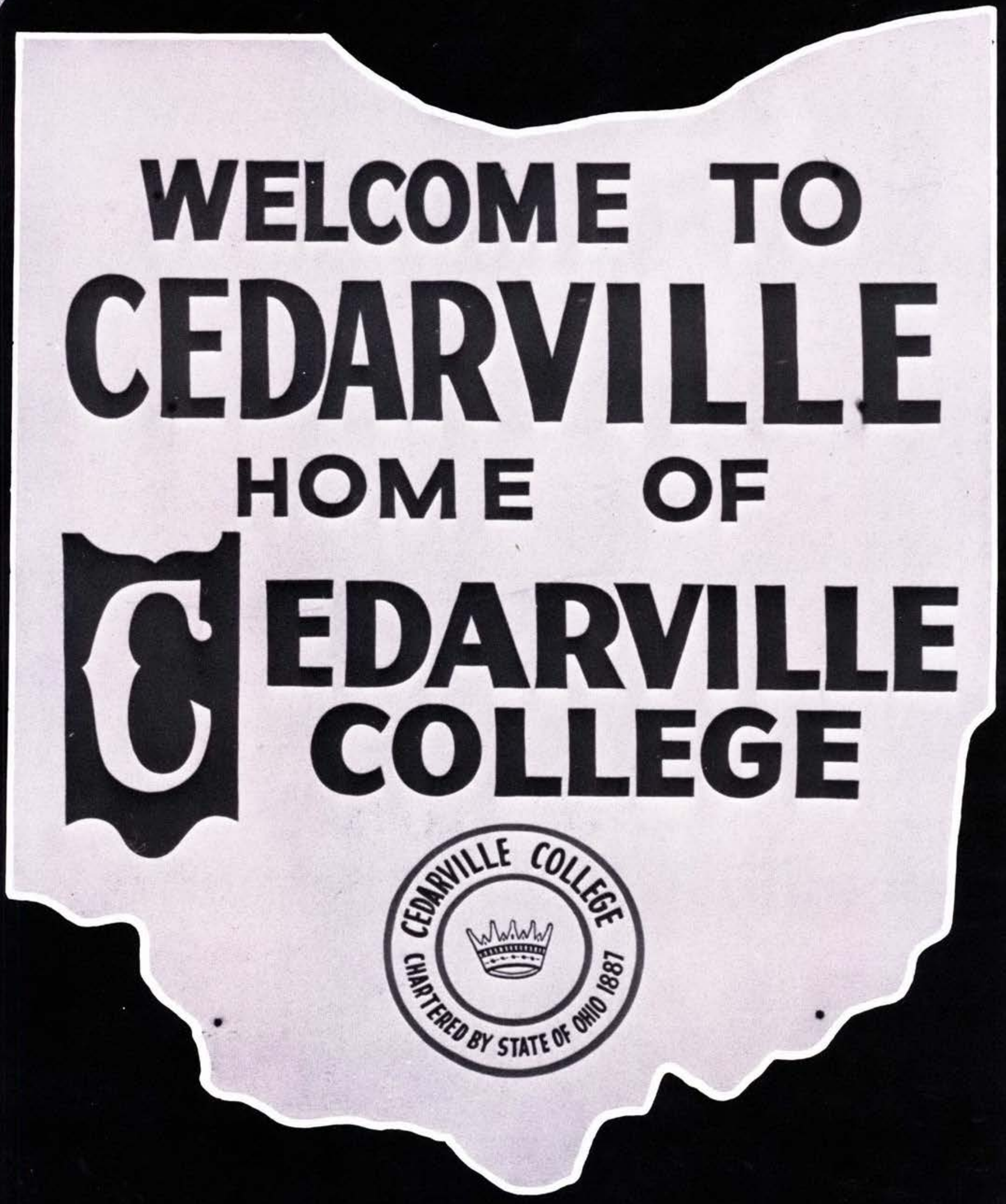




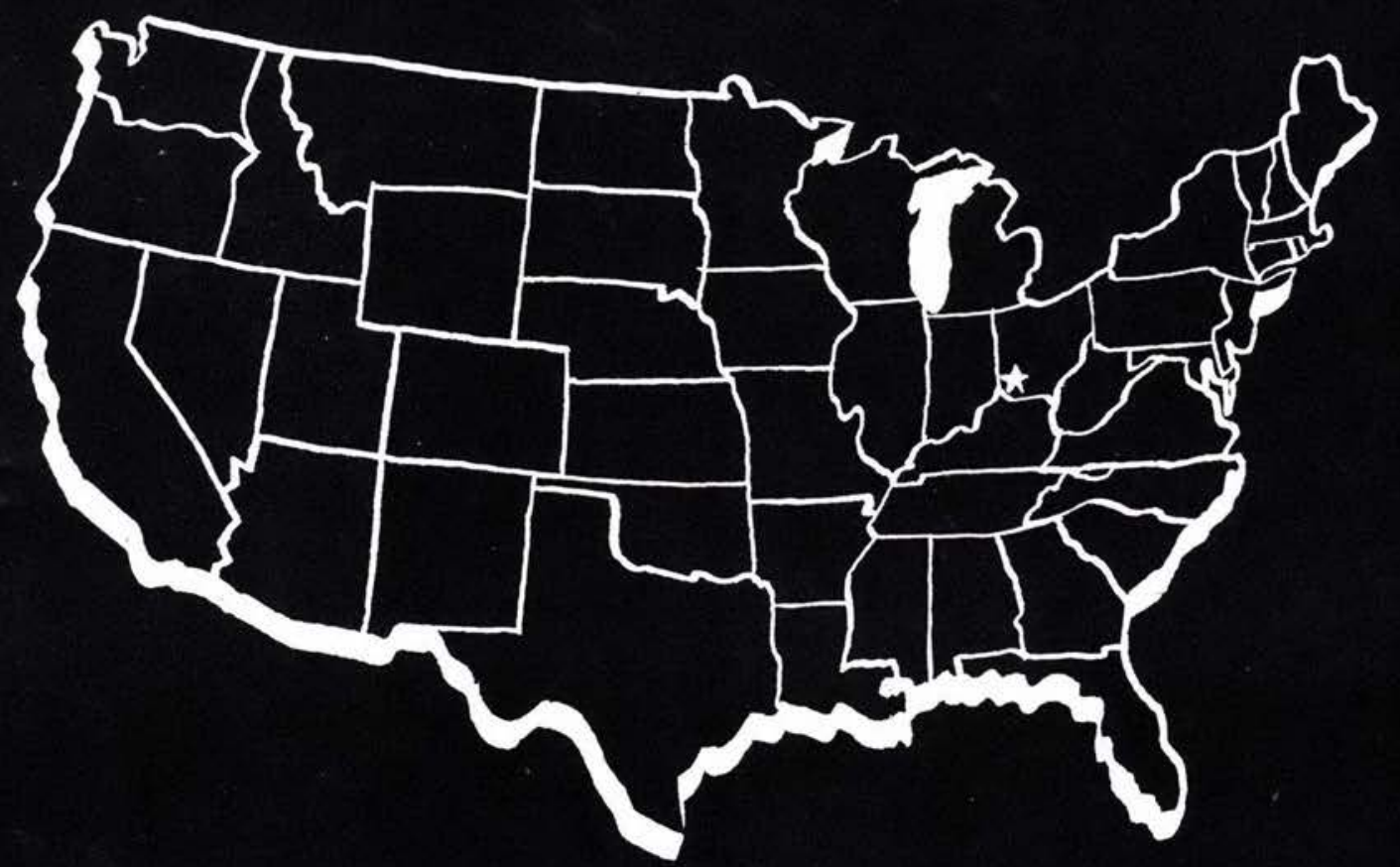

From across the country,

And around the world,

Come together 1000 people

To one place - Cedarville.

Each has set his own goals,

His own aspirations,

His own ideas for the future.

It is the first big step

At becoming an individual.

He has left his home,

His parents, his friends.

All these people have one

Common thing which binds them close together -

A faith in a loving, living God.

Each represents some

Different attitude or concept of Him,

But all share the same truth.

For nine months they strive

To live, work, and play in harmony,

Seeking in all to give glory

To the One who guides.

1972 was a gift from Him -

This book and the things it contains

Are the story of that year.

It shall remain as a memorial

To that year and to us.

For as we scan these pages,

We'll remember

And always thank Him for such a

place as this 

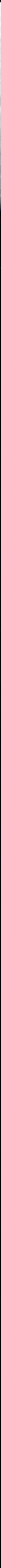

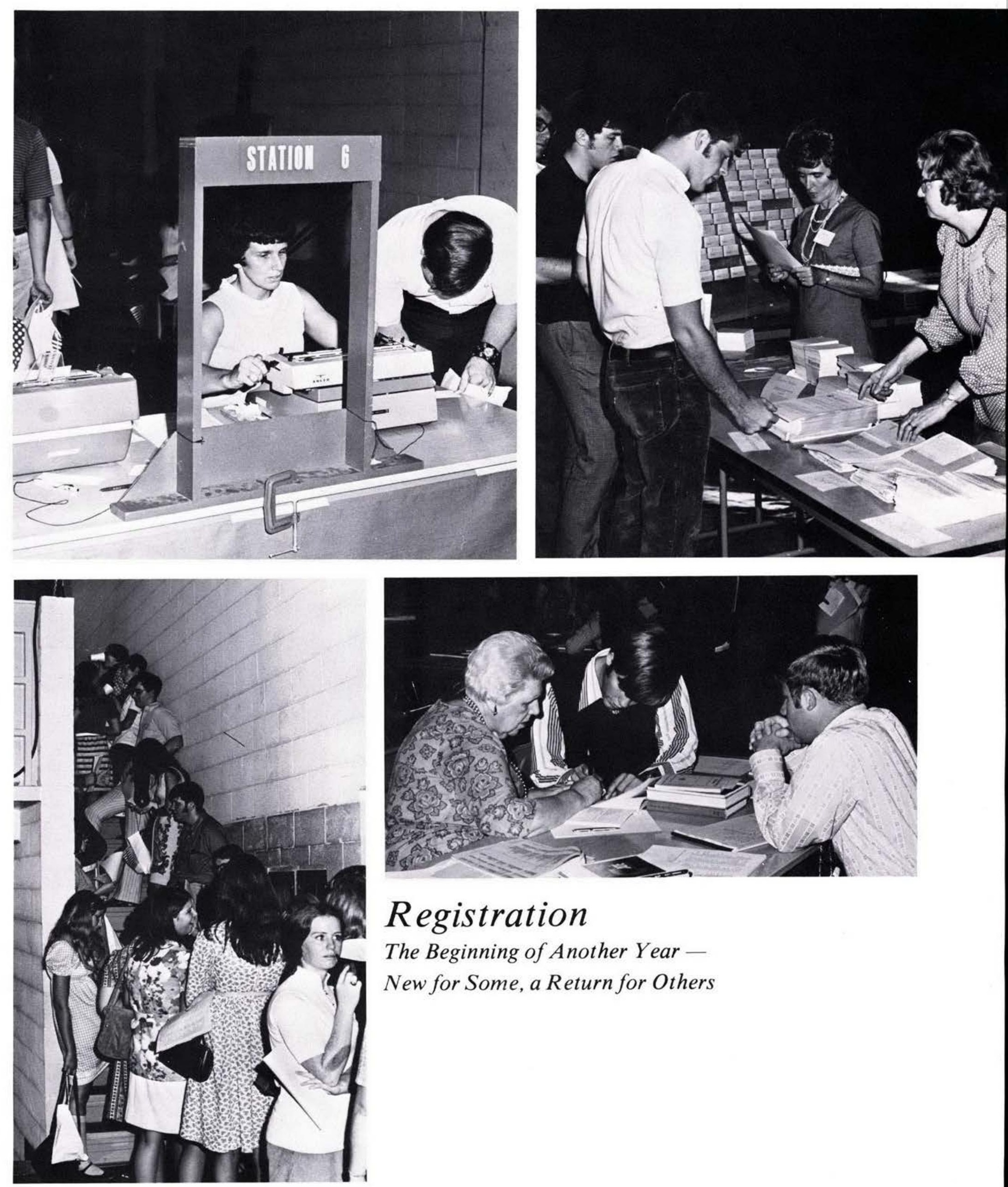

\section{Registration}

The Beginning of Another Year-

New for Some, a Return for Others 
Freshman Nightmare
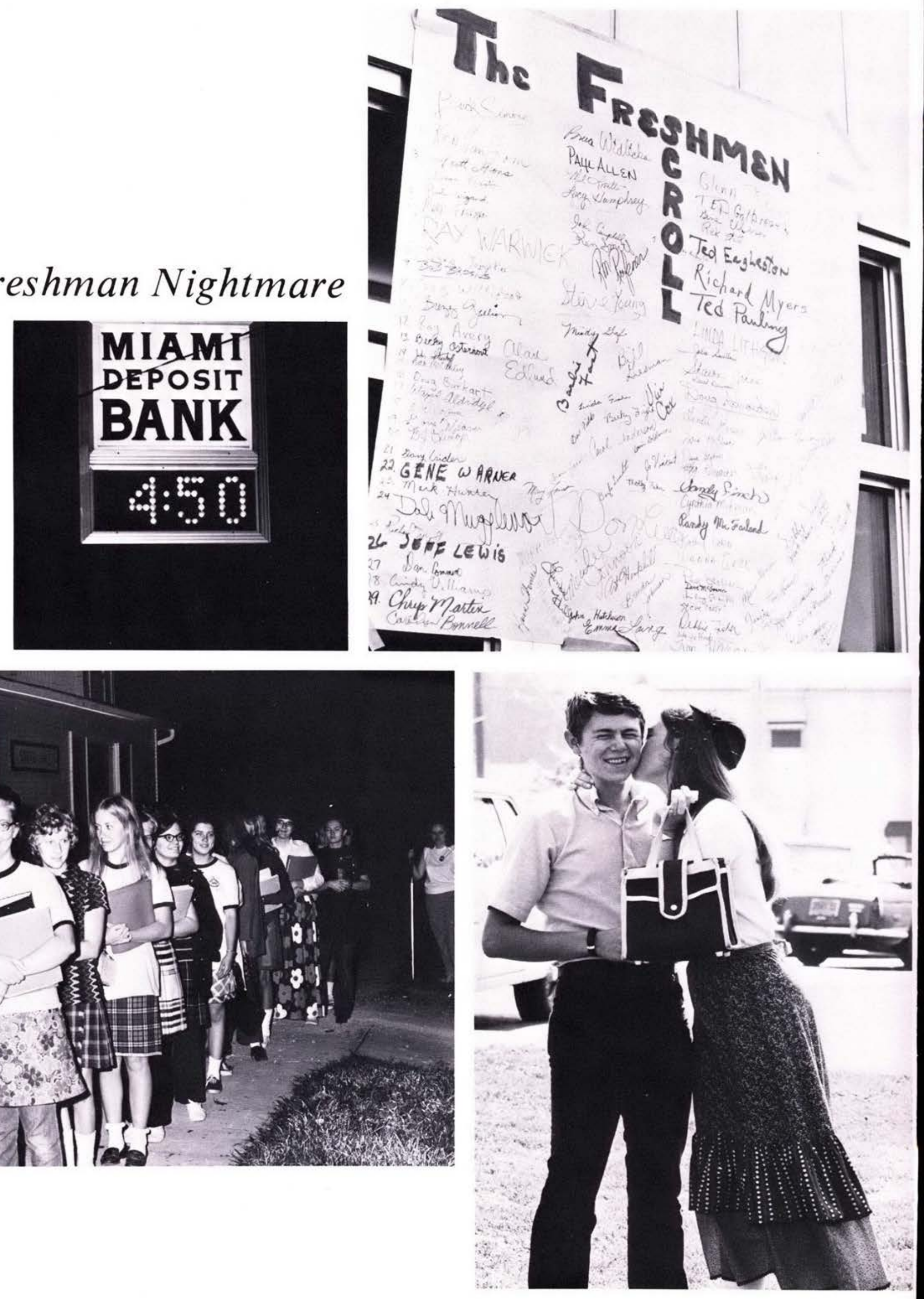
1.

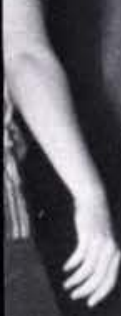

$(4)$

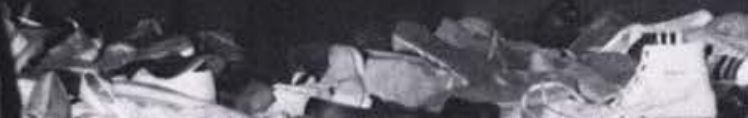

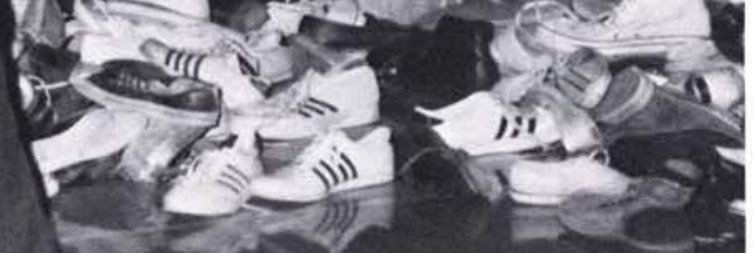
$\operatorname{Lis}^{\circ}$
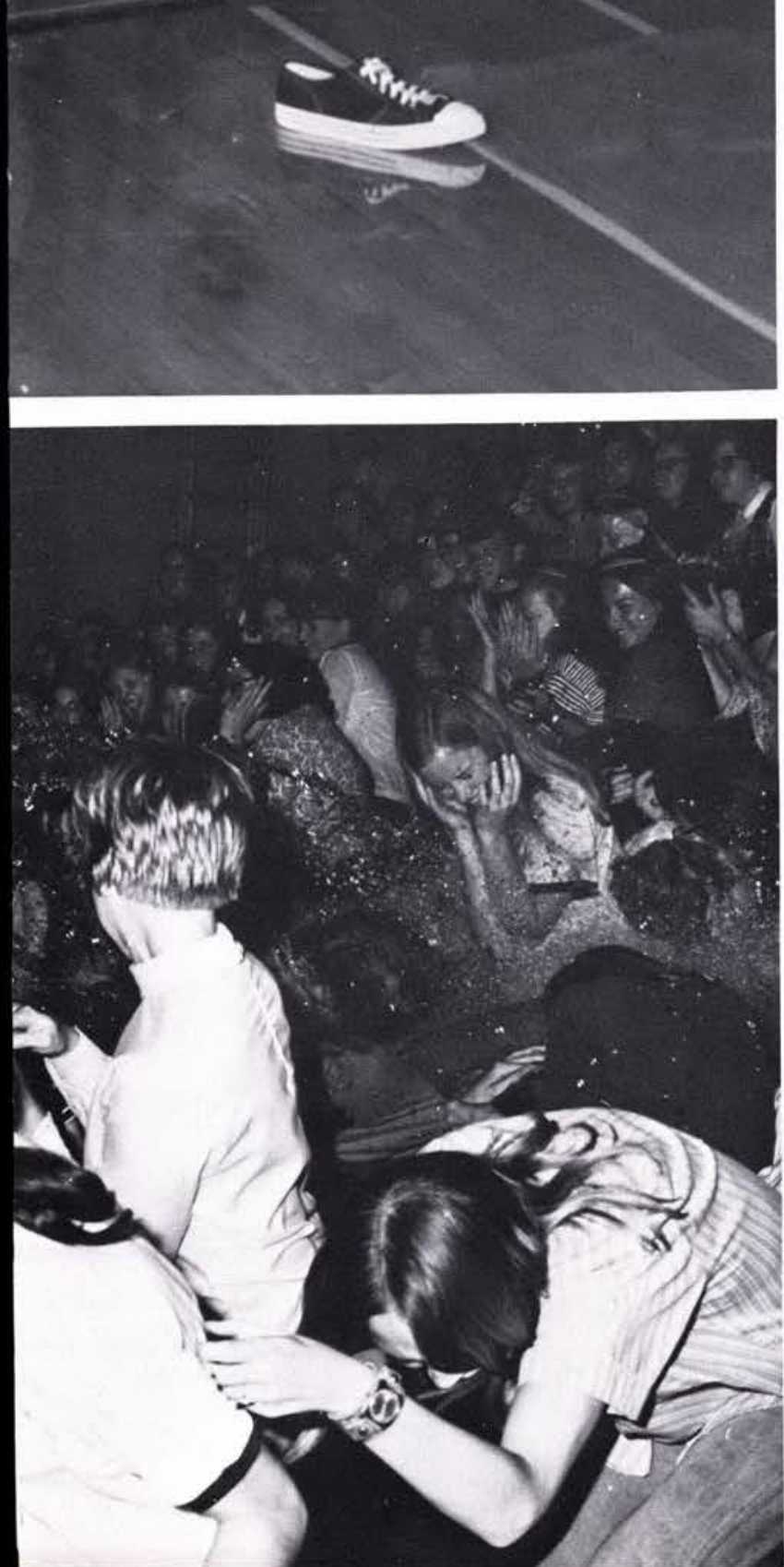
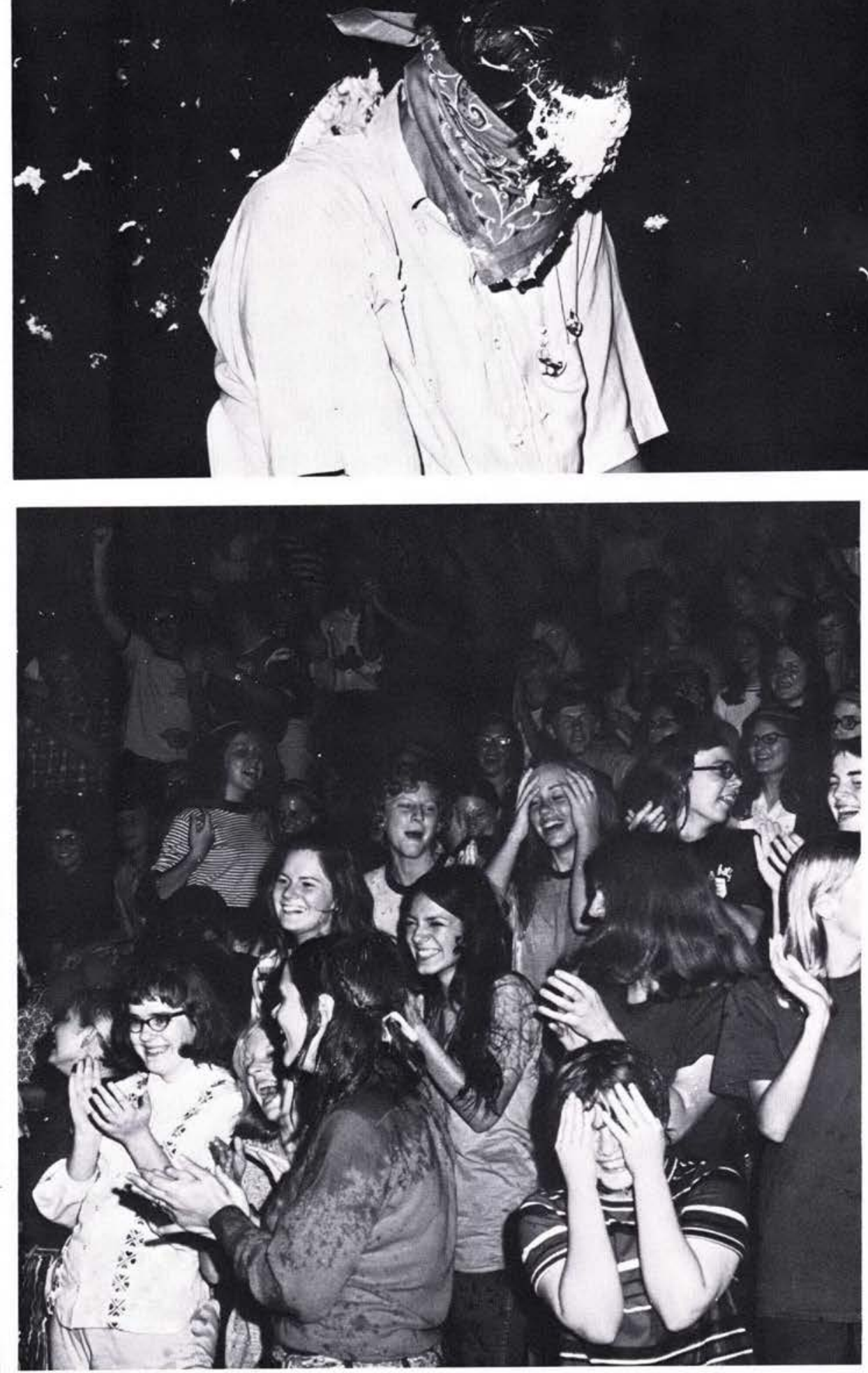

wet and wild ... 

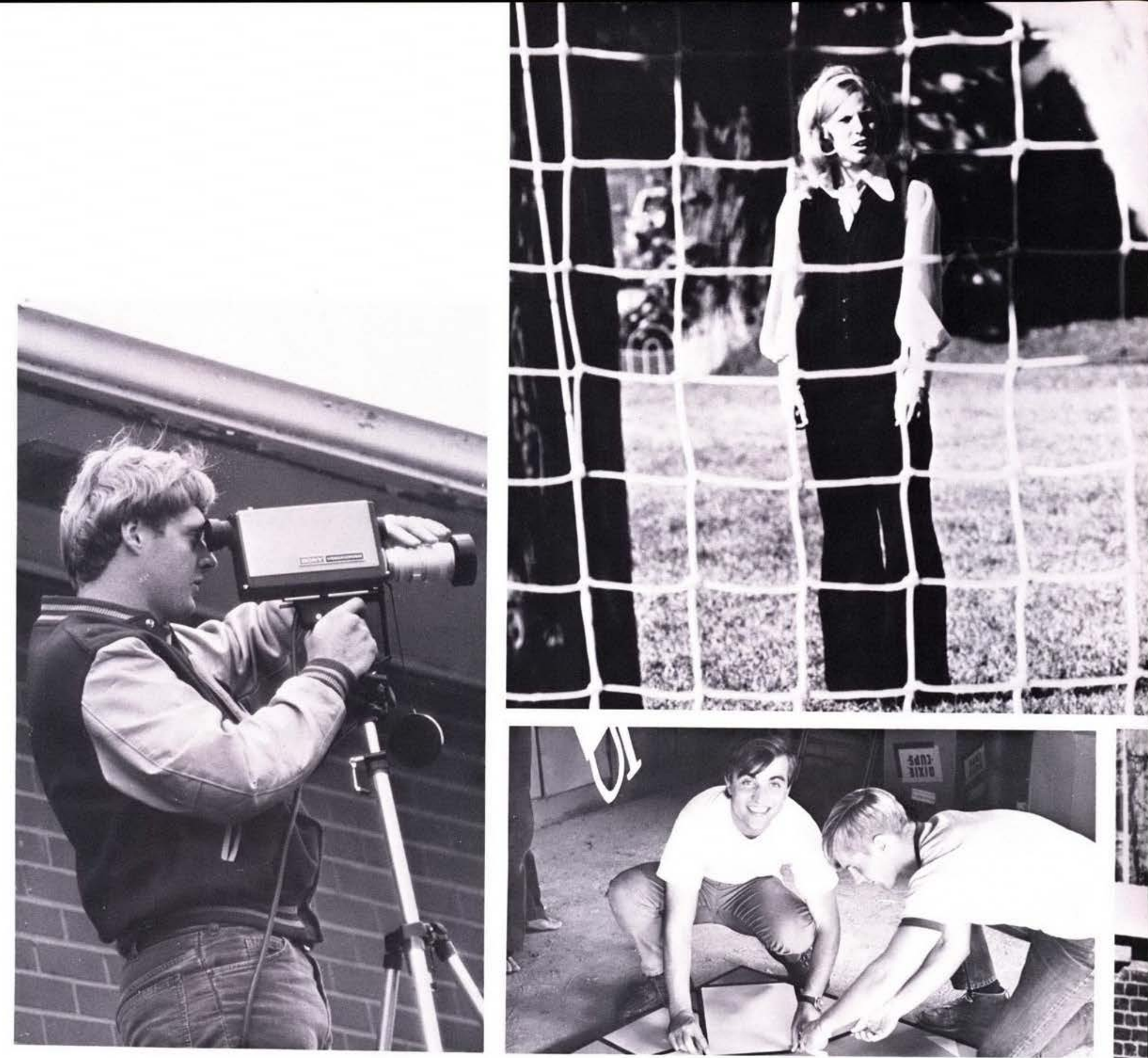

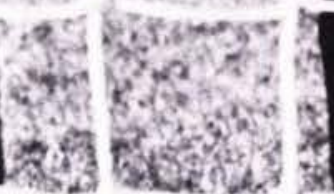
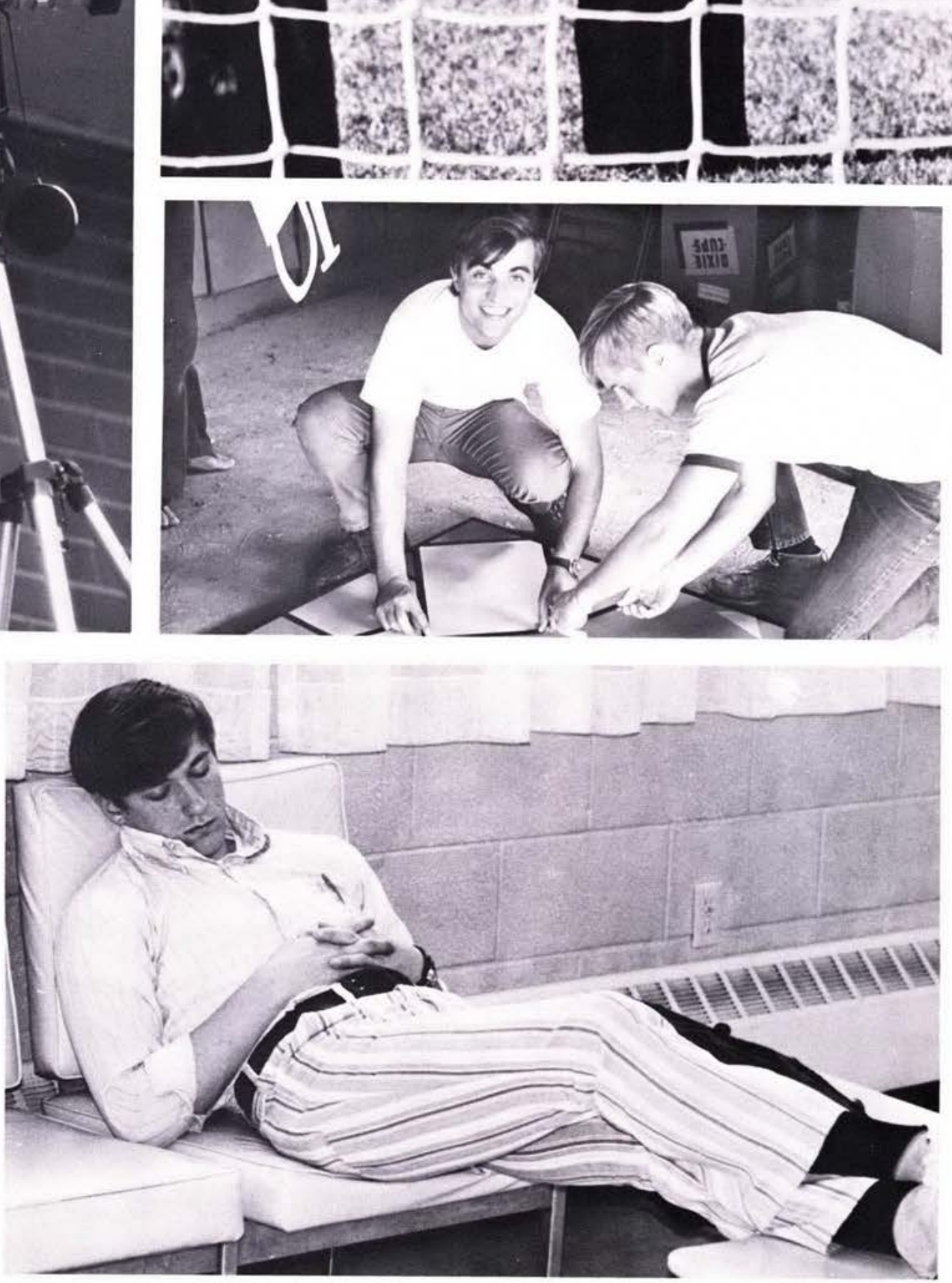


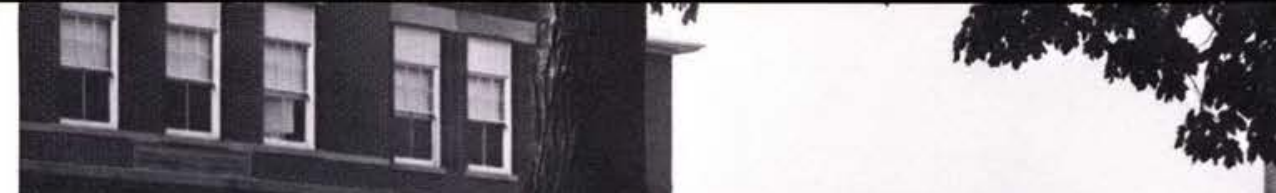



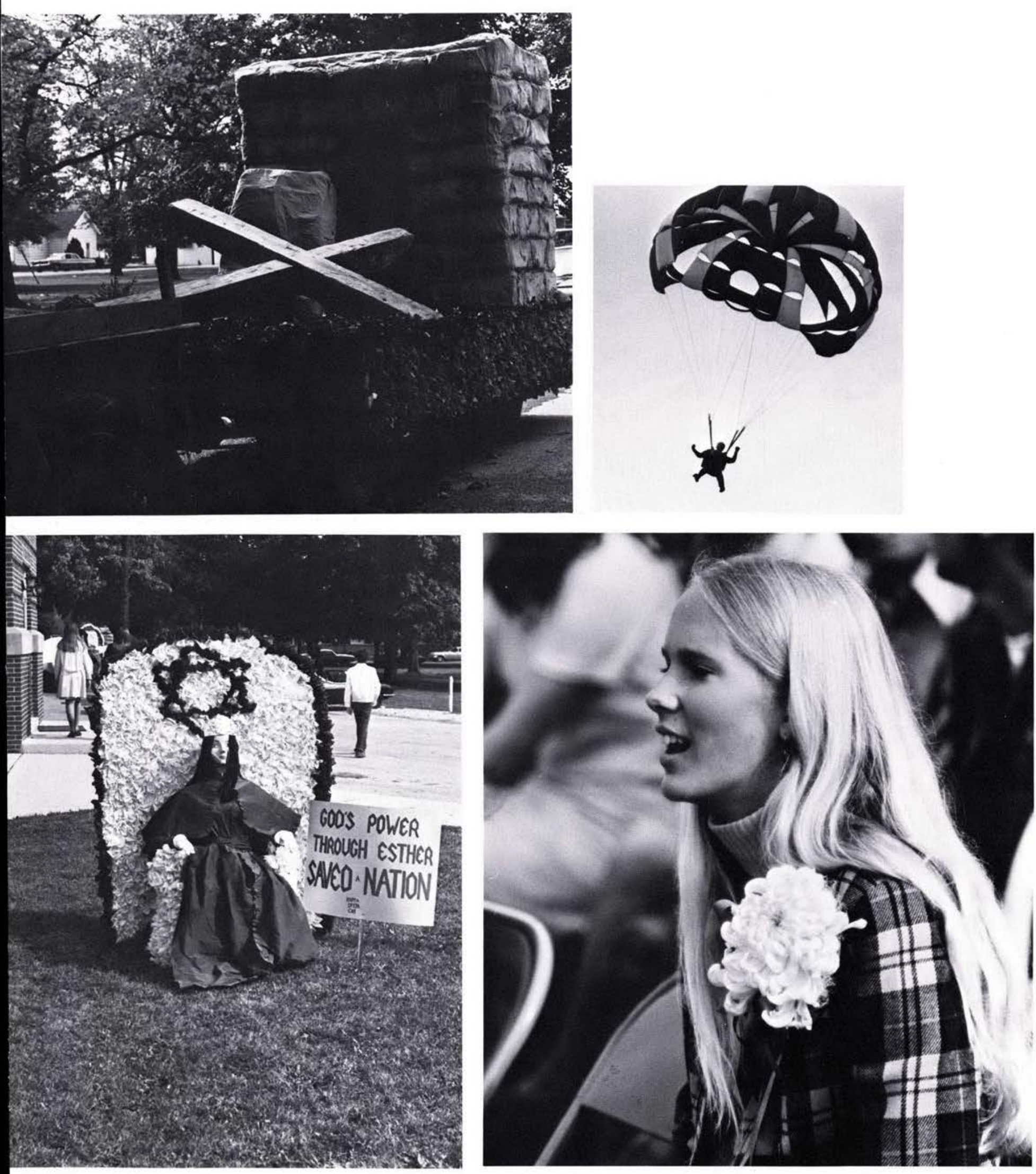

Showing forth the power of God ... challenge to give our all for the glory of God ... a soccer game we'll never forget - a big win over Cincinnati ... a soccer ball brought down by a parachute ... we crowned a new queen ... they all wore mums ... a first-time visit to the campus for some ... a return to memories for many alumni ... it was really - OUR WEEKEND. 

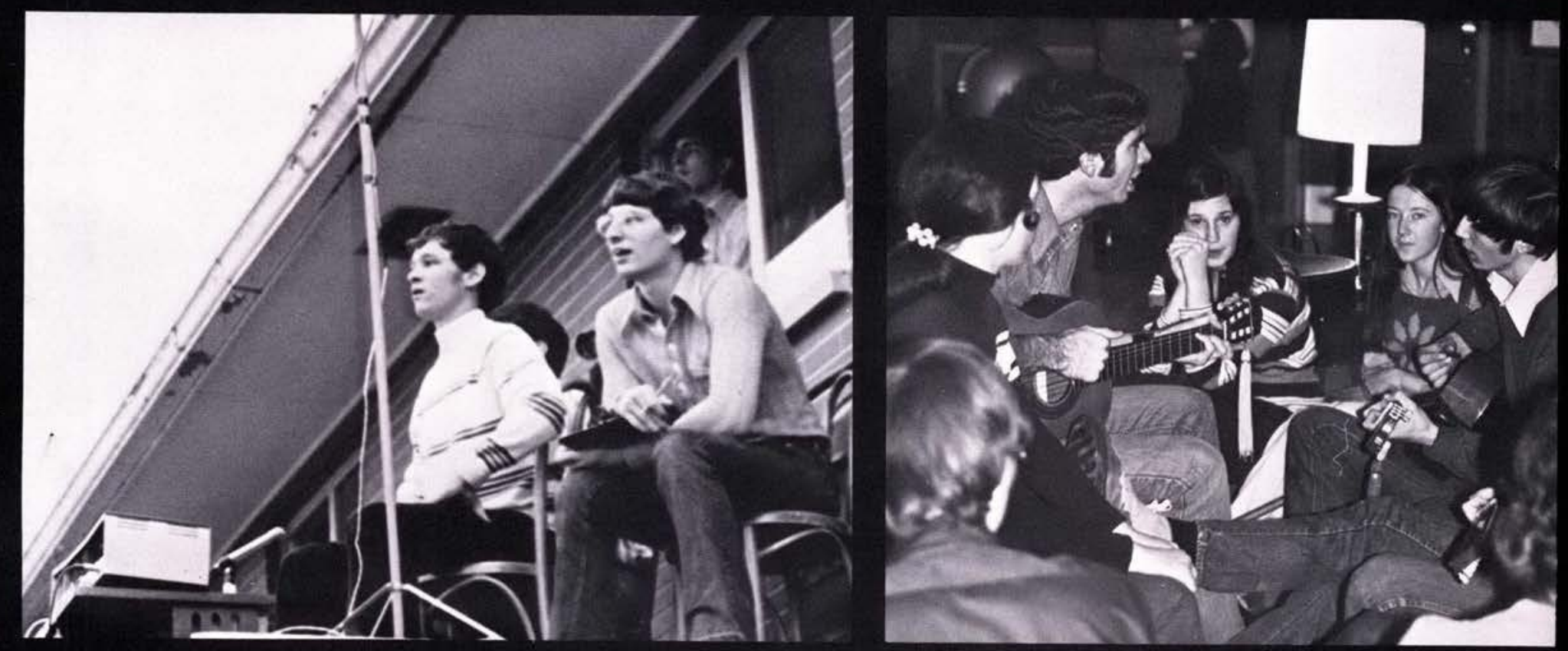

Everyday People Like... . 

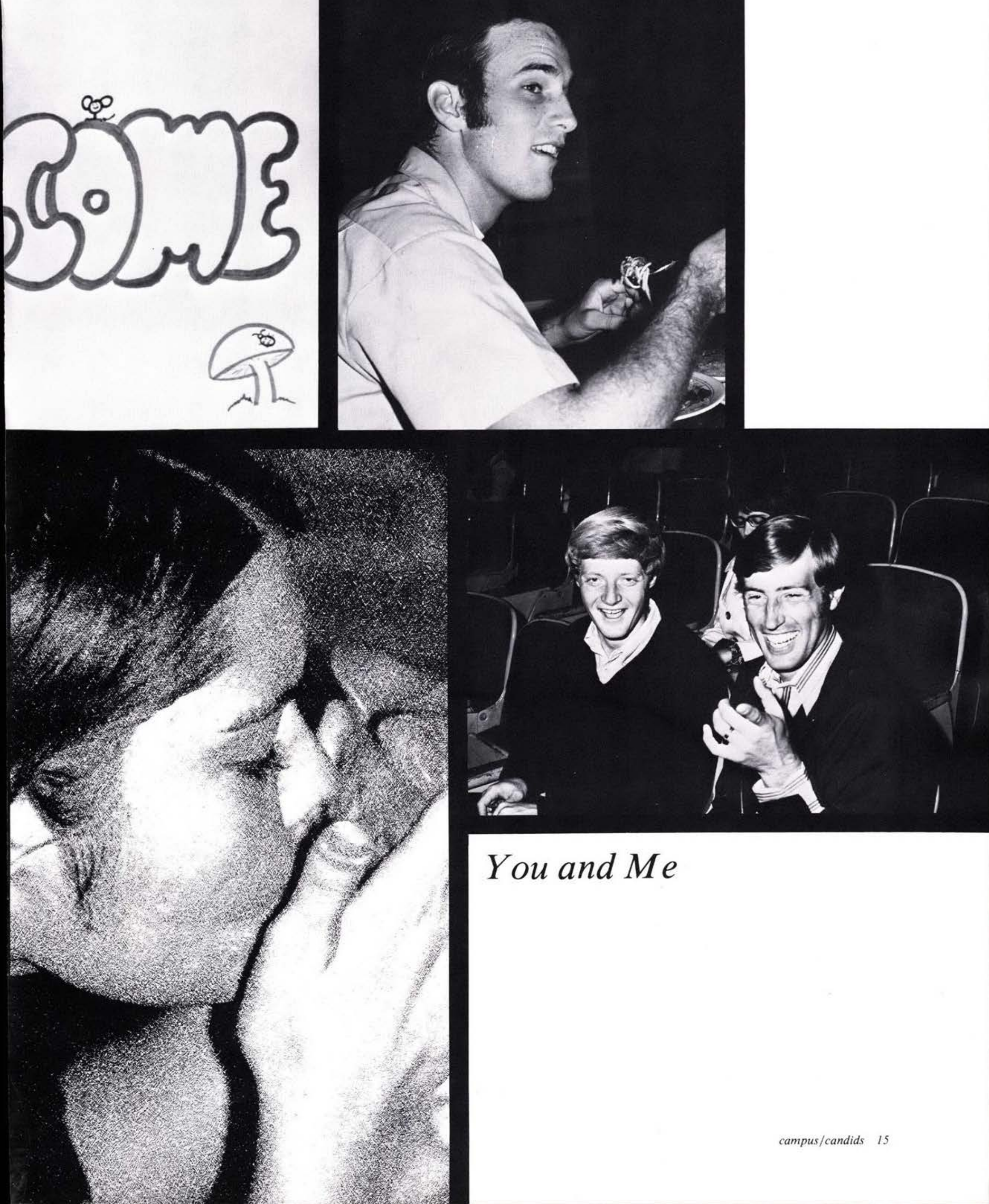

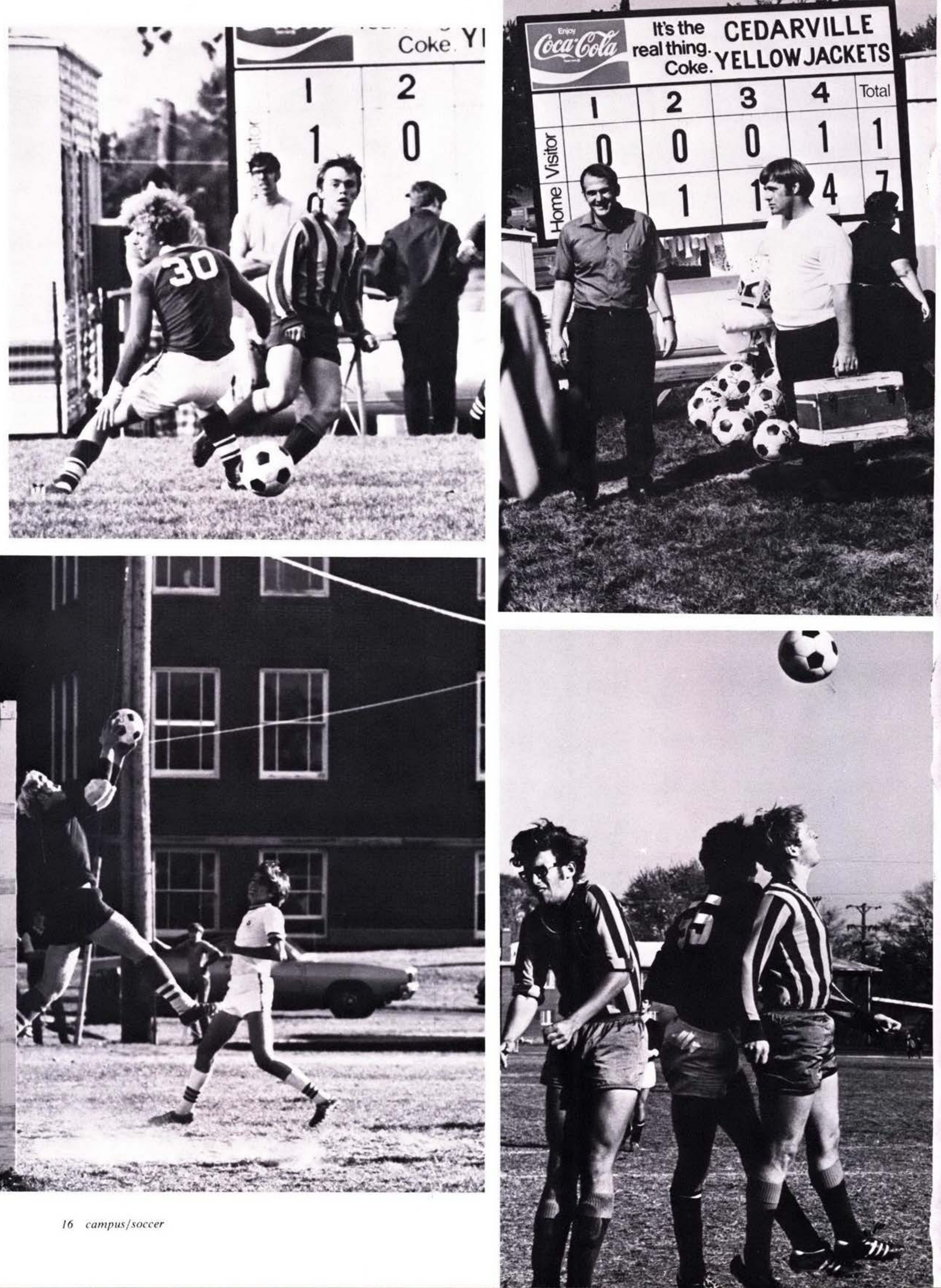


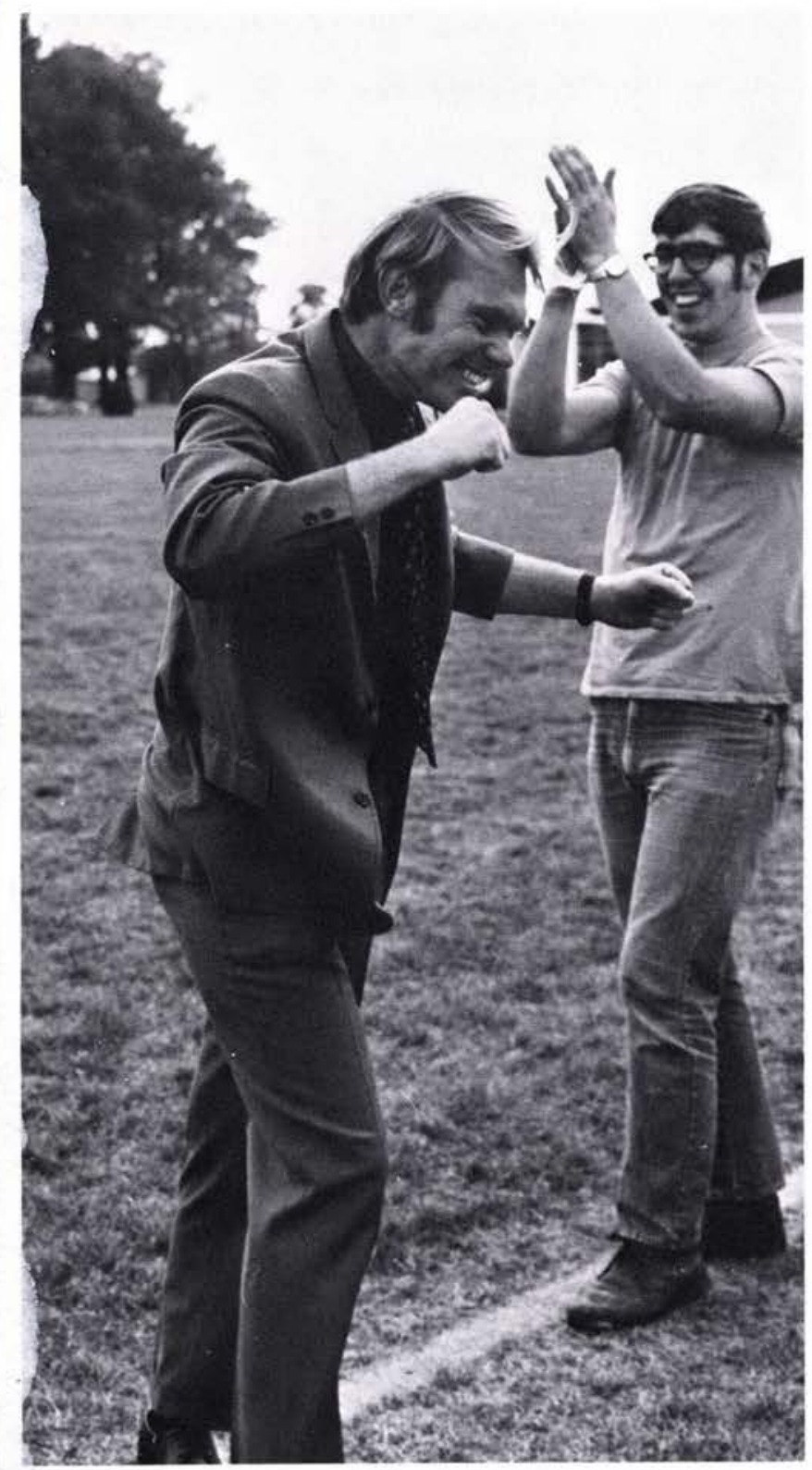

\section{SOCCER it's a winner}
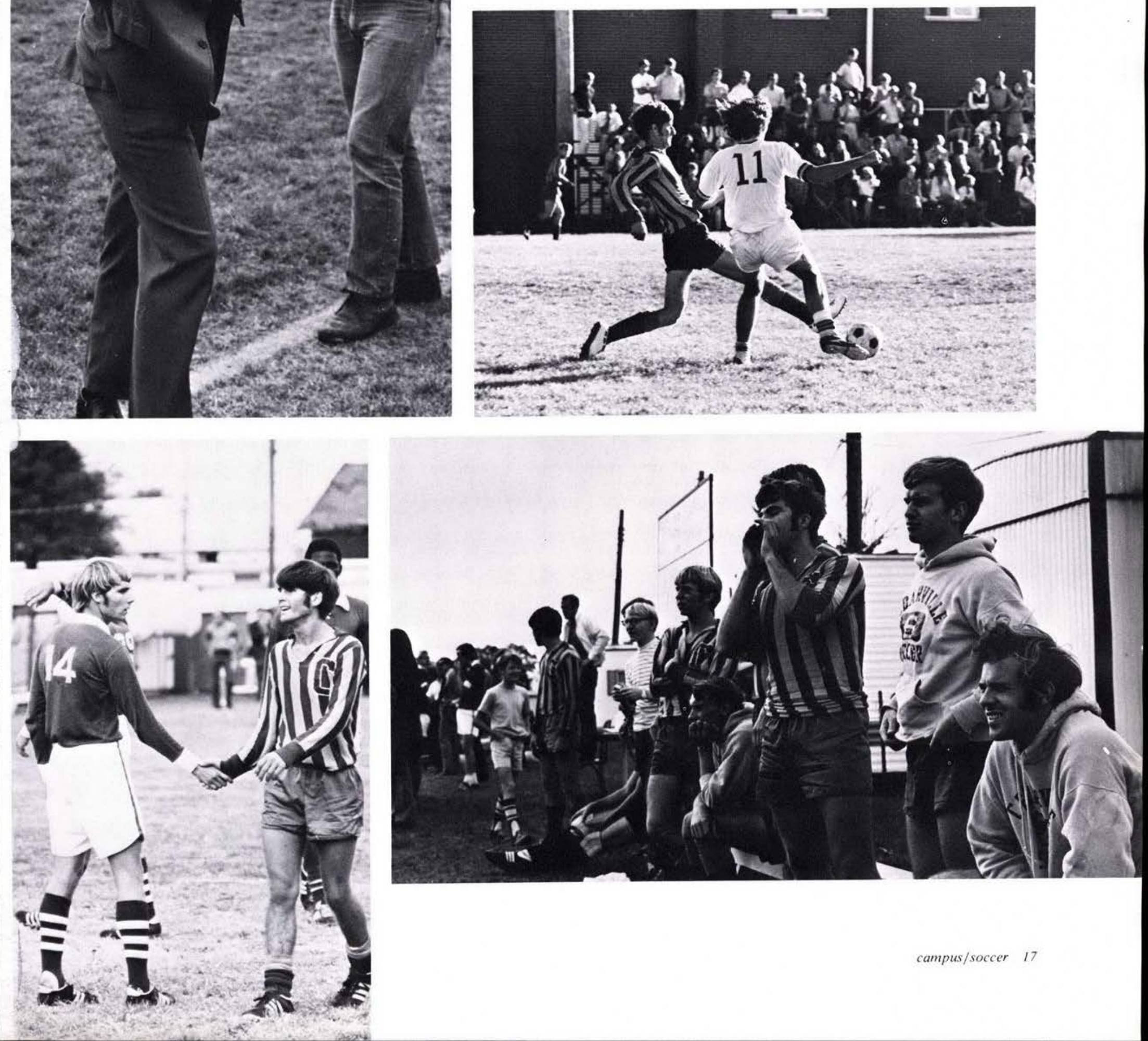


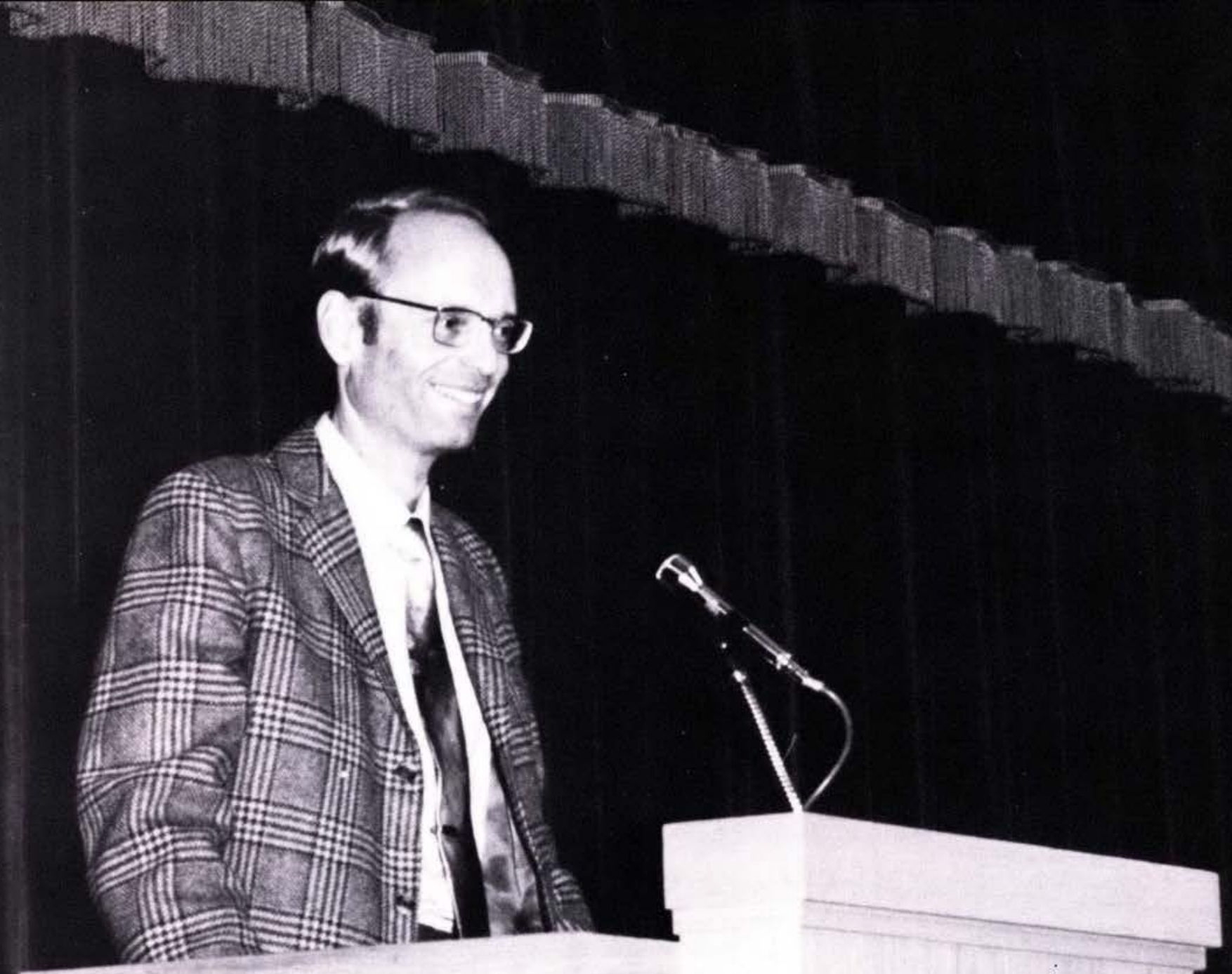




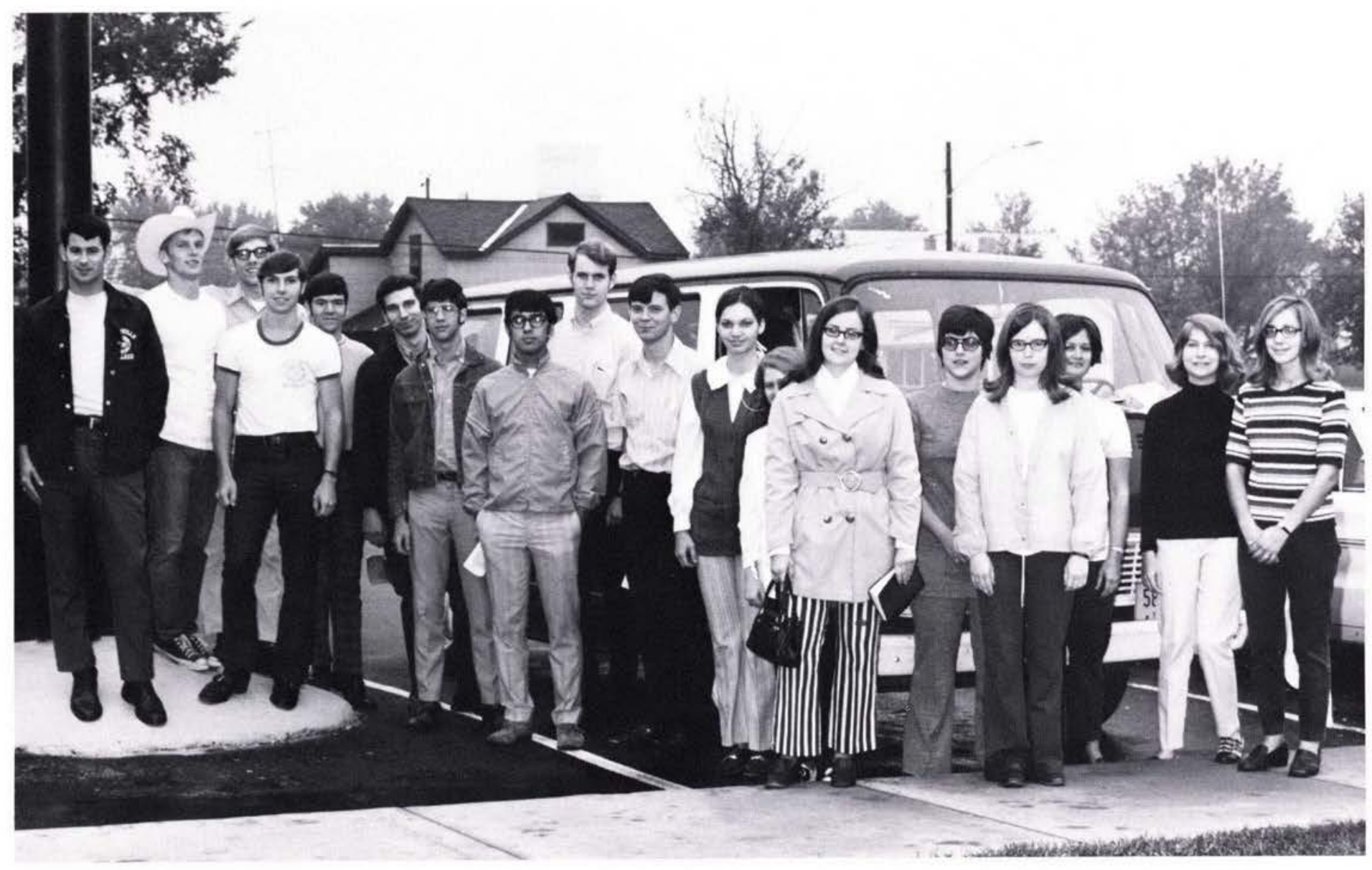

Stan Seevers, Lyle Miller, Tom Seidler, Kevin Holden, Dennis Twigg, Dan Thompson, Terry Holly, Al Konya, Paul Radcliff, Sharon Gallogly, Sue Seldon, Linda Wilms, Merla Hammack, Bernice Penegor, Priscilla Russell, Suzanne Hale, Sharon Gazdik.

\section{Swordbearers - Fall Tour}

18 people in two vans for two weeks...

They traveled east to New York and Pennsylvania,

A journey of 1,200 miles

They visited 10 churches -

Conducting seminars on the Establishment,

Evangelism, Drugs, and Sex and Dating

Gospel magic highlighted their talents .

And God blessed in the sowing of the seed. 

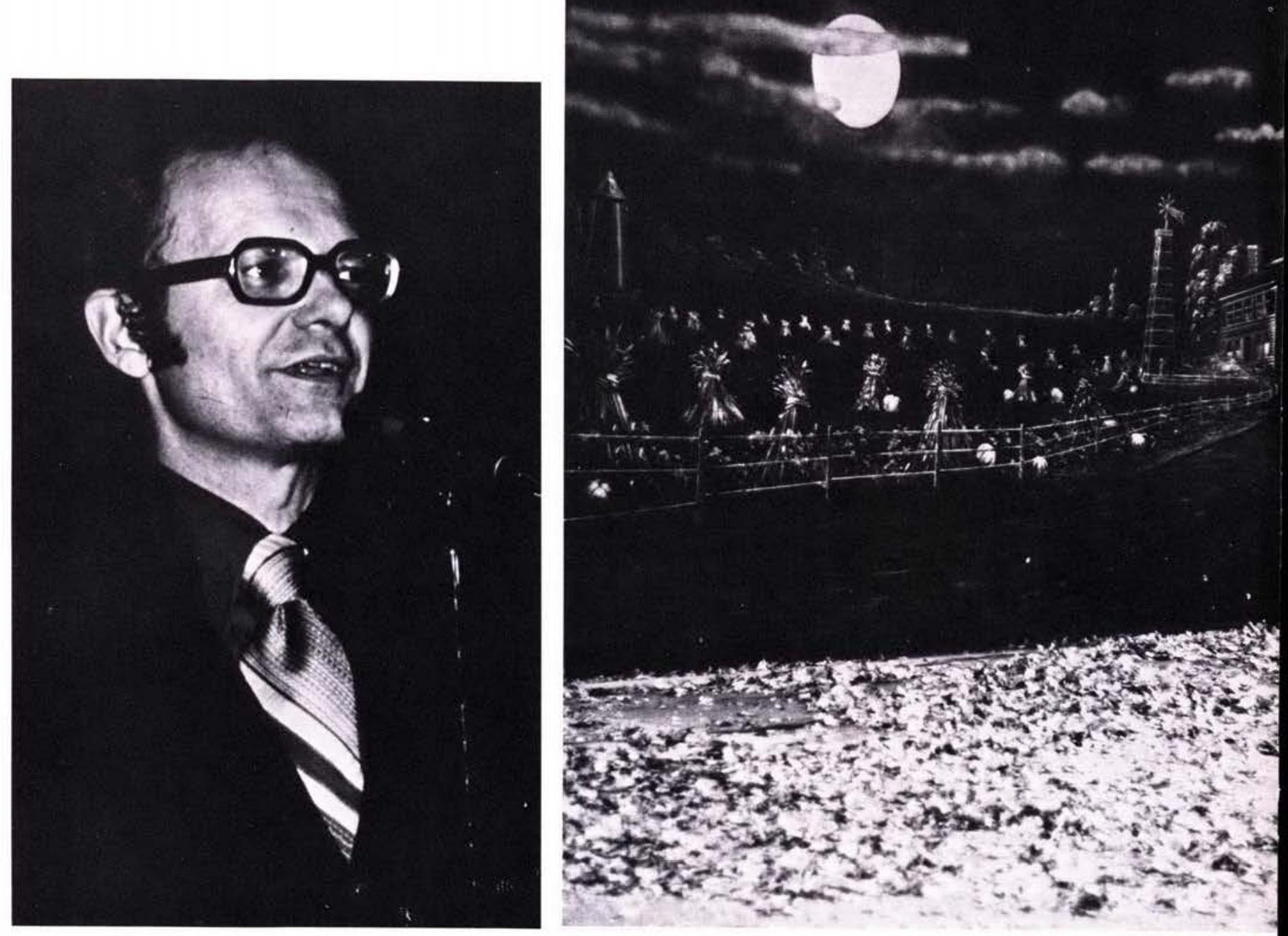

Harvest of Harmonies Bales of hay,

Pumpkins, wagons, Harmony in fours Talking trombones, The AX Sweetheart, Jokes and laughter Smiles and fun,

A grand finale for a beautiful season.

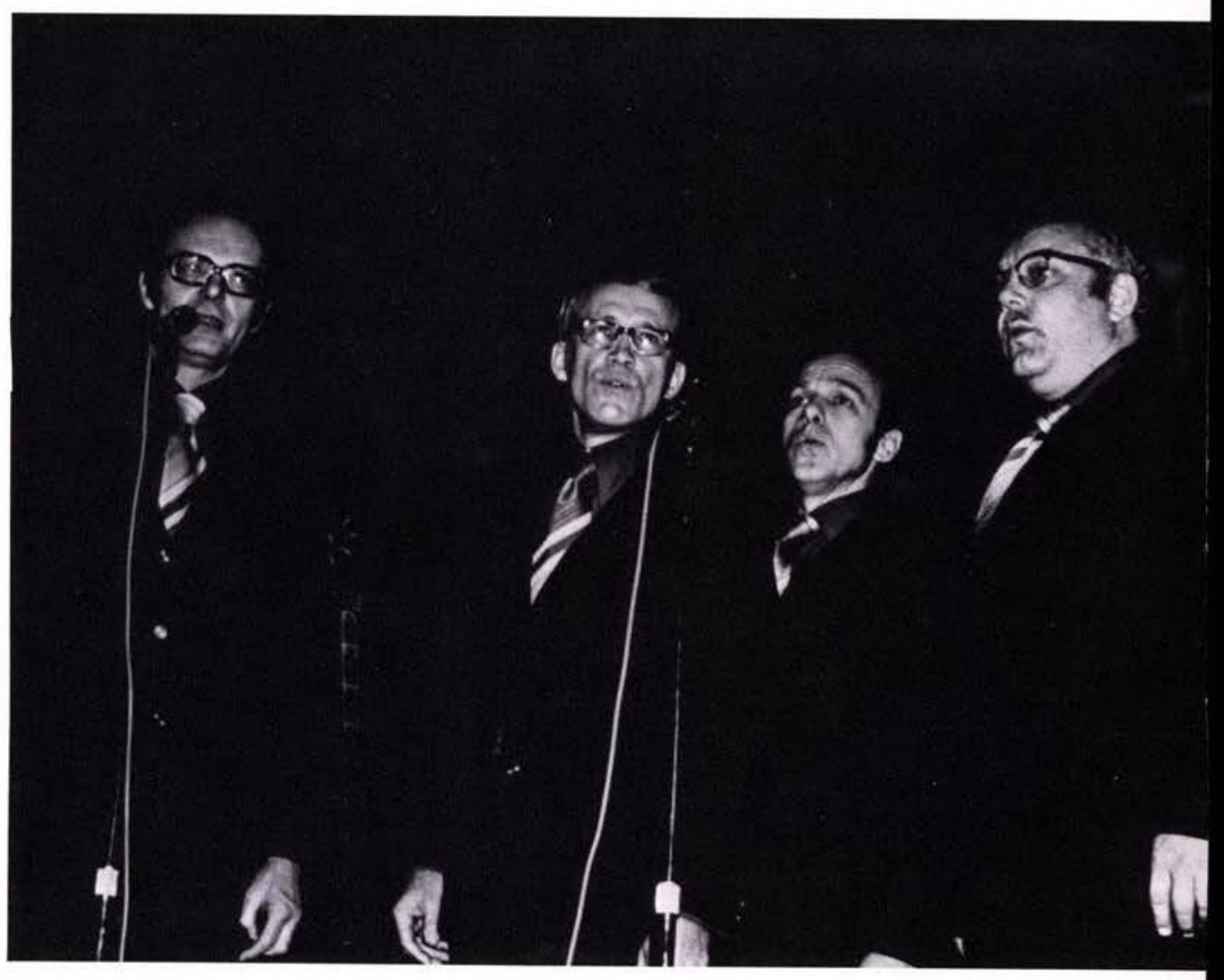




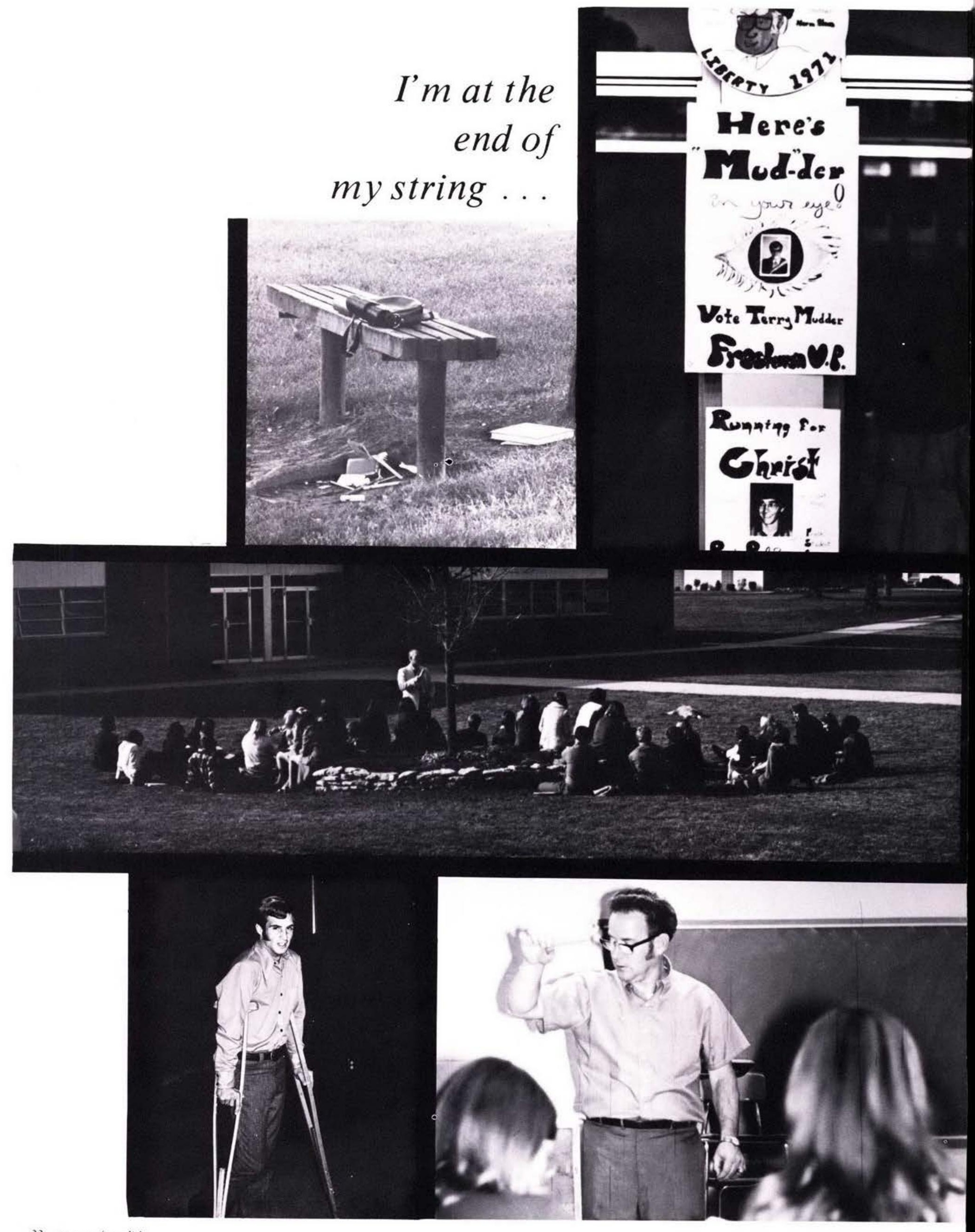



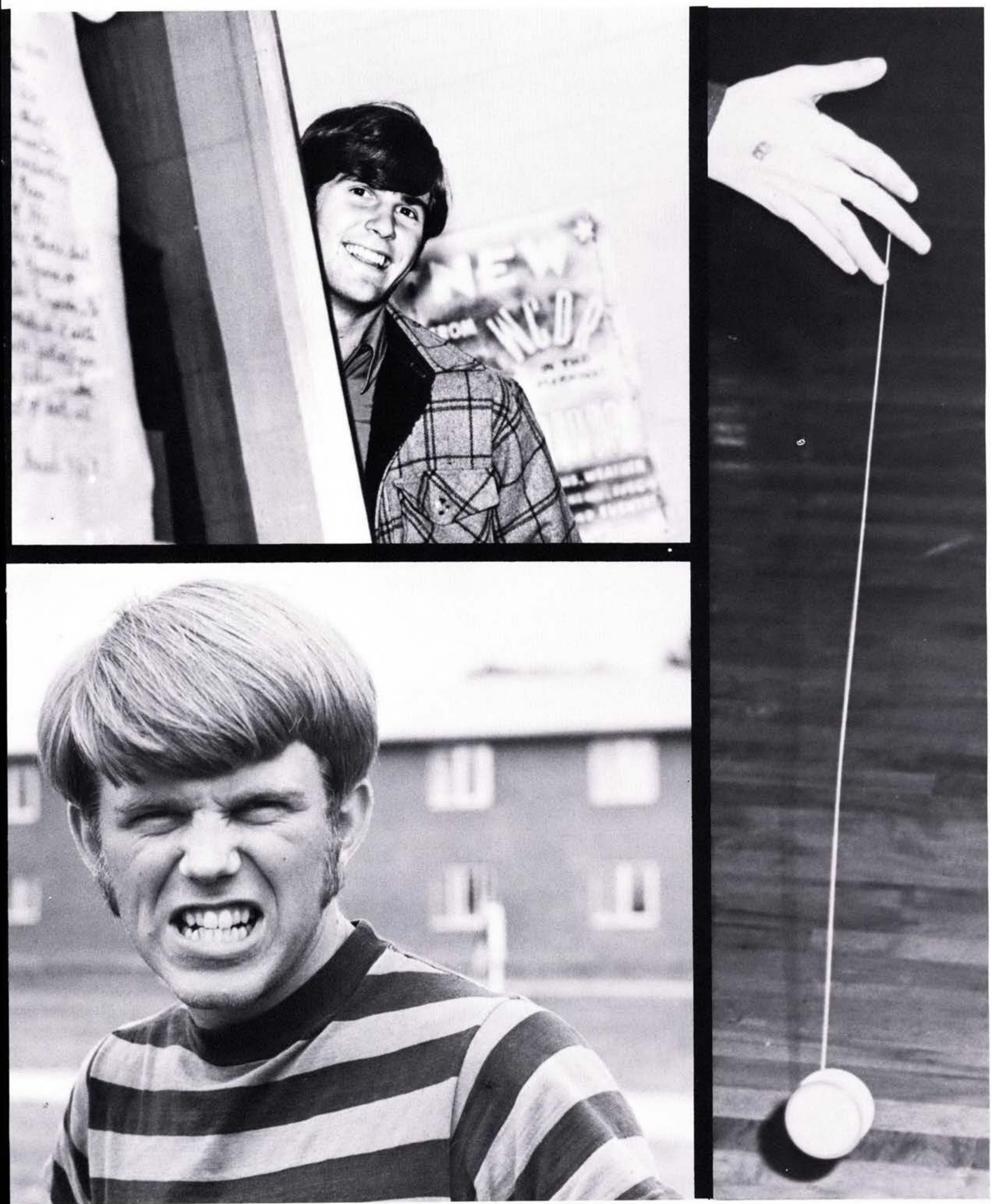

campus/candids 23 


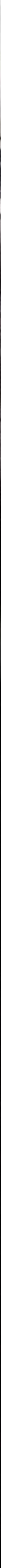

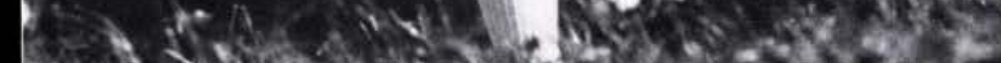

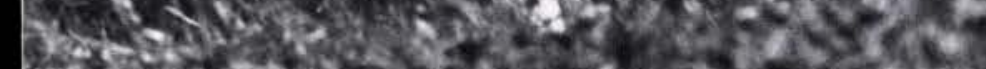

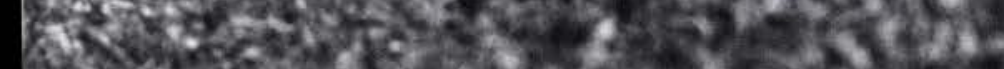



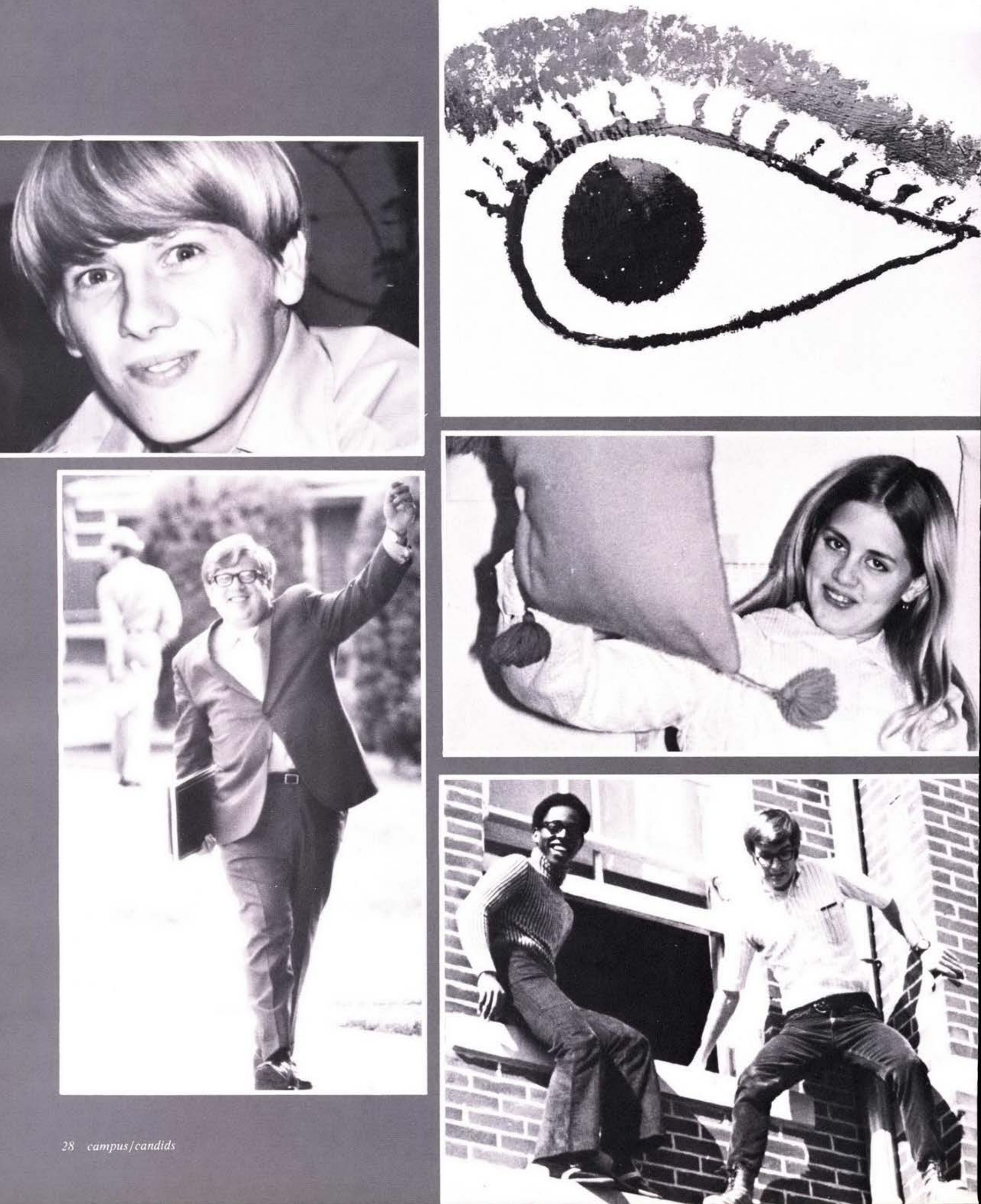

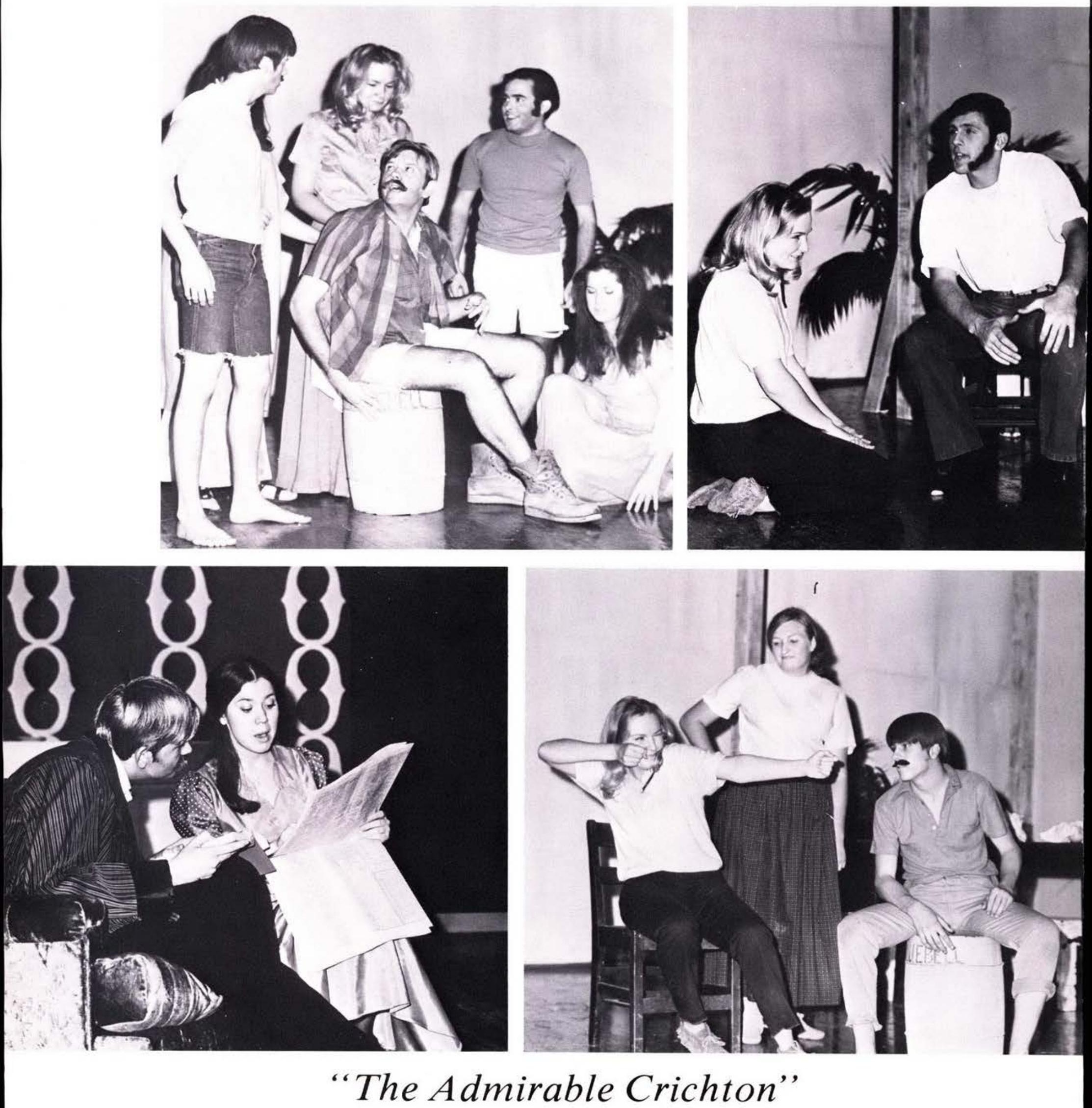

"The Admirable Crichton" 


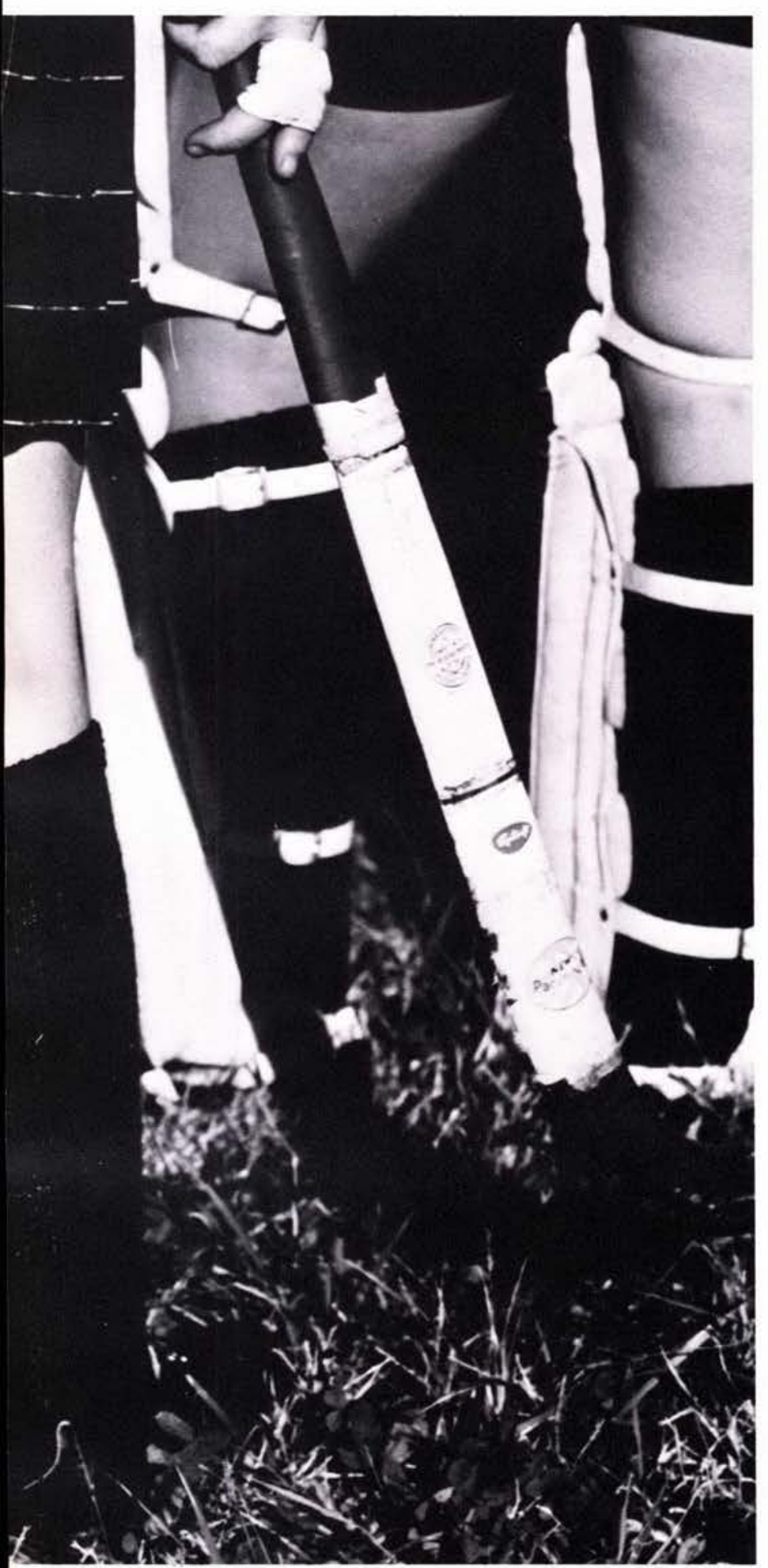

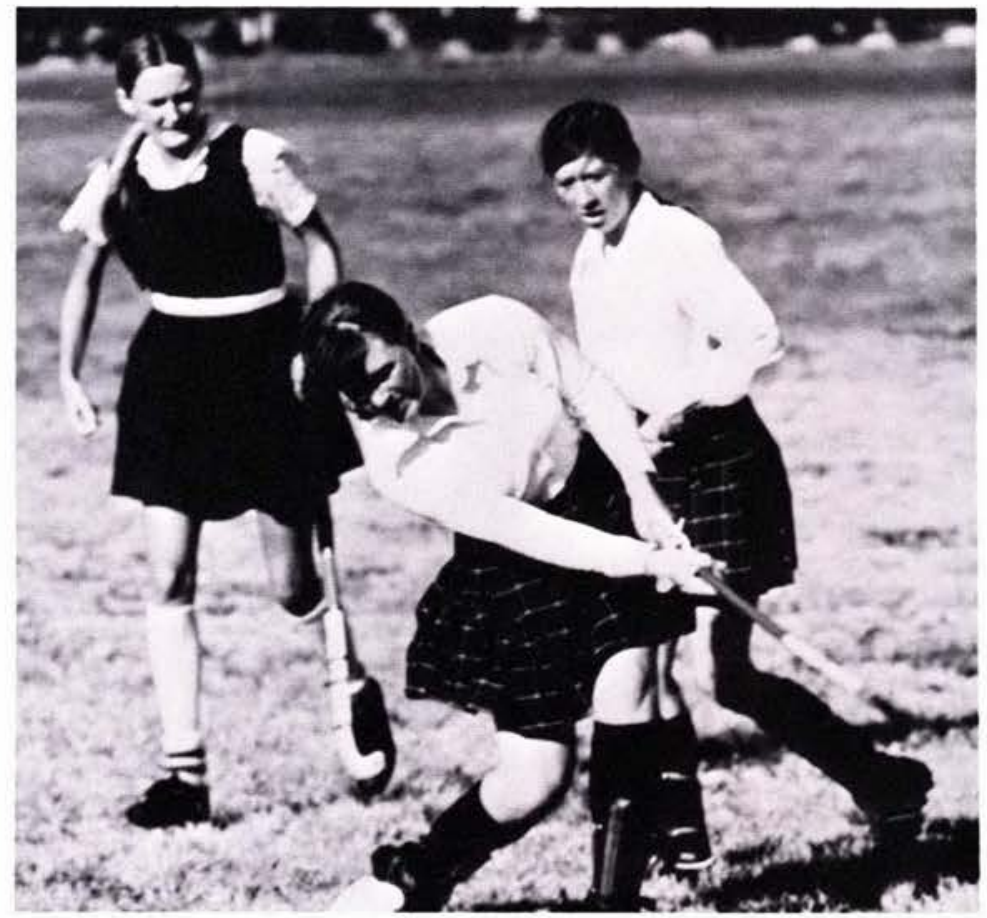

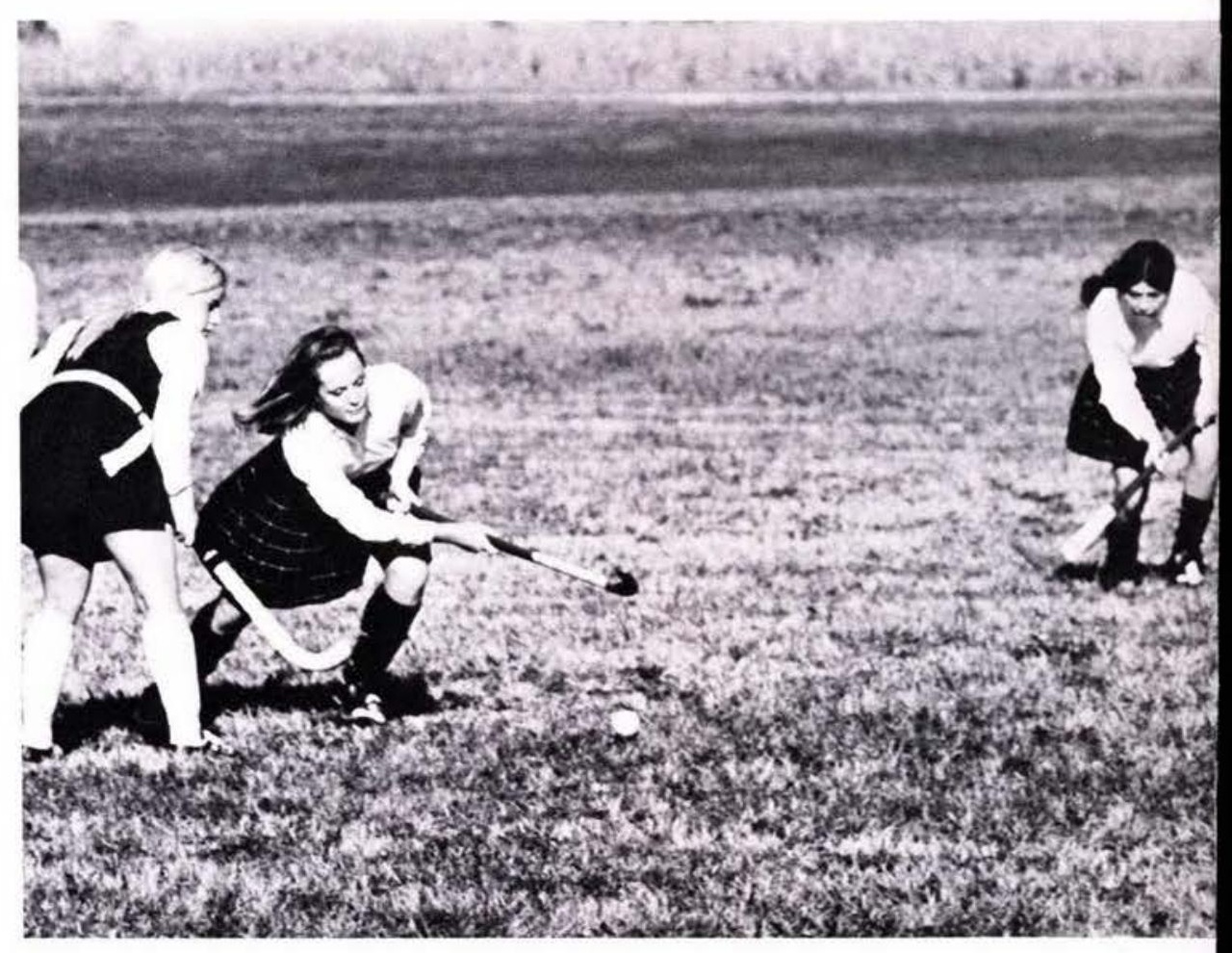

Happiness is . . . 


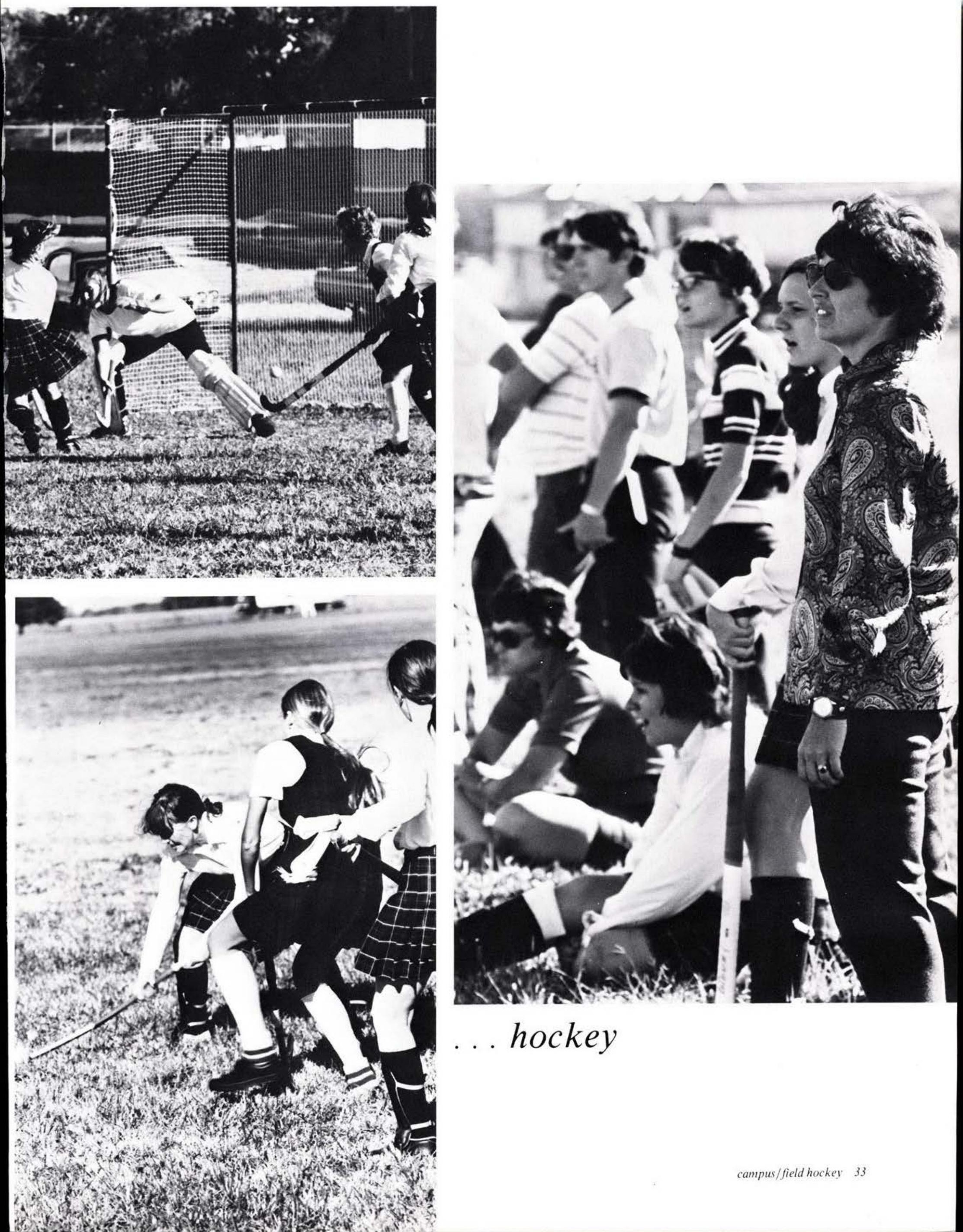



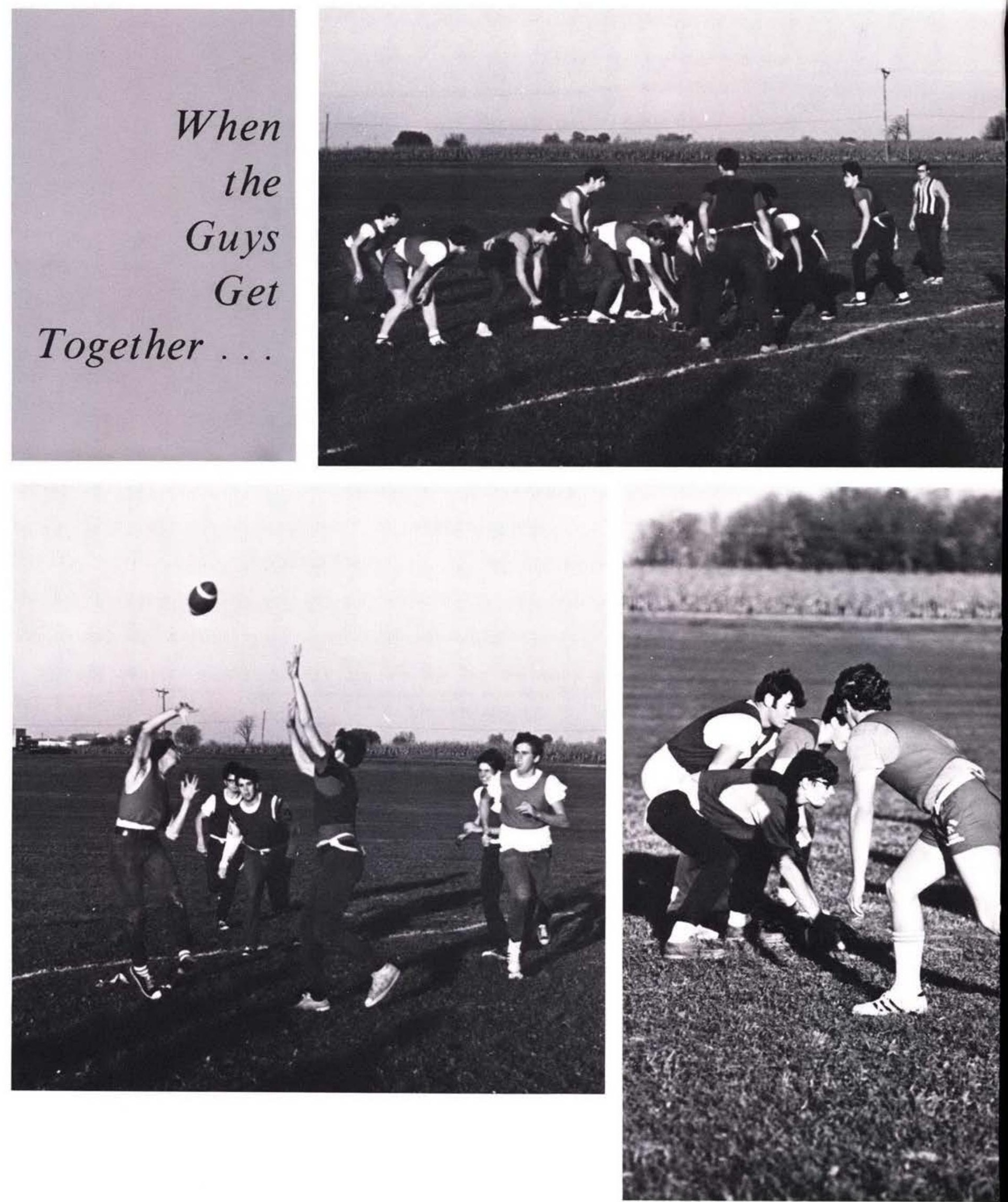

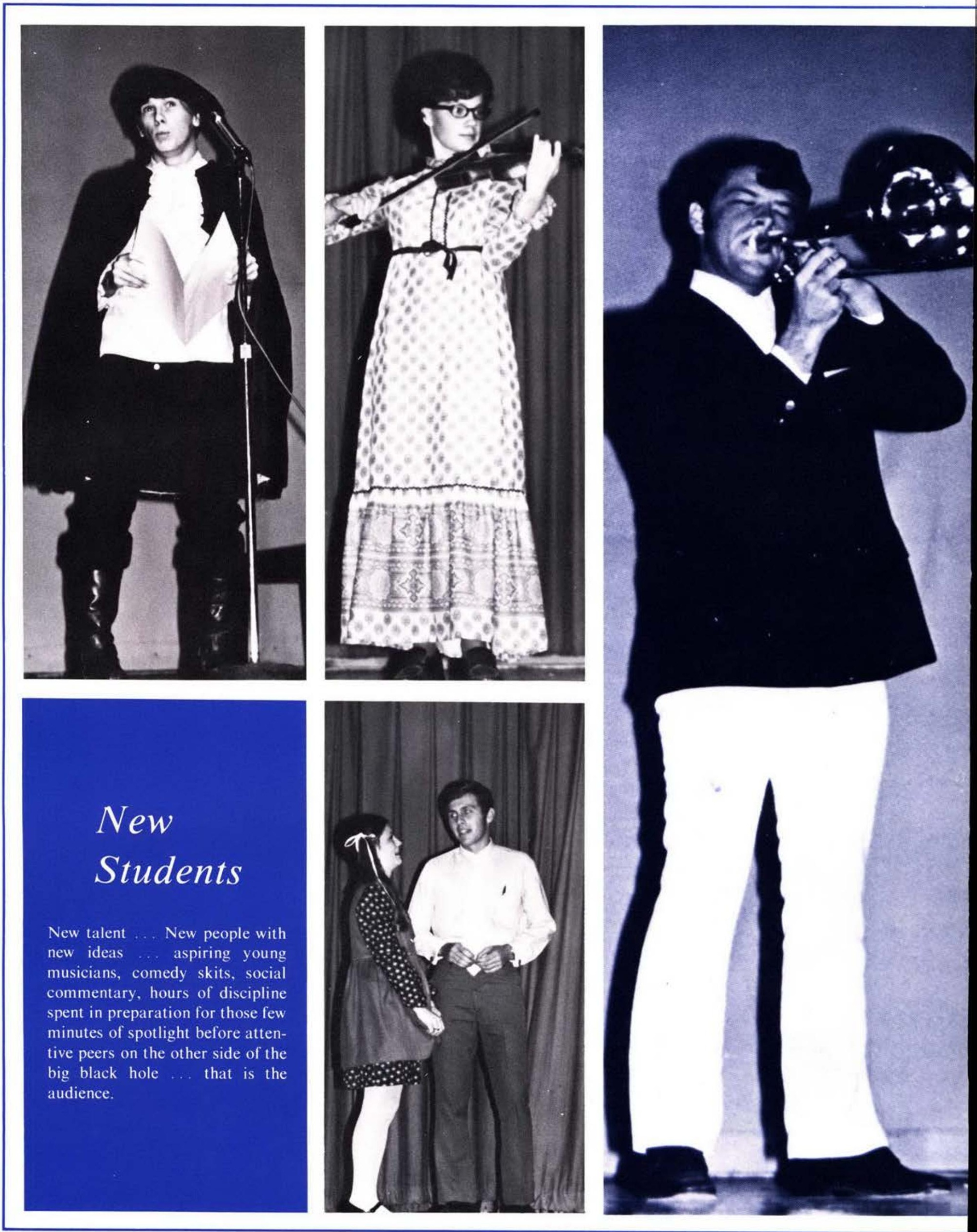

New talent ... New people with new ideas .... aspiring young musicians, comedy skits, social commentary, hours of discipline spent in preparation for those few minutes of spotlight before attentive peers on the other side of the big black hole .... that is the audience.

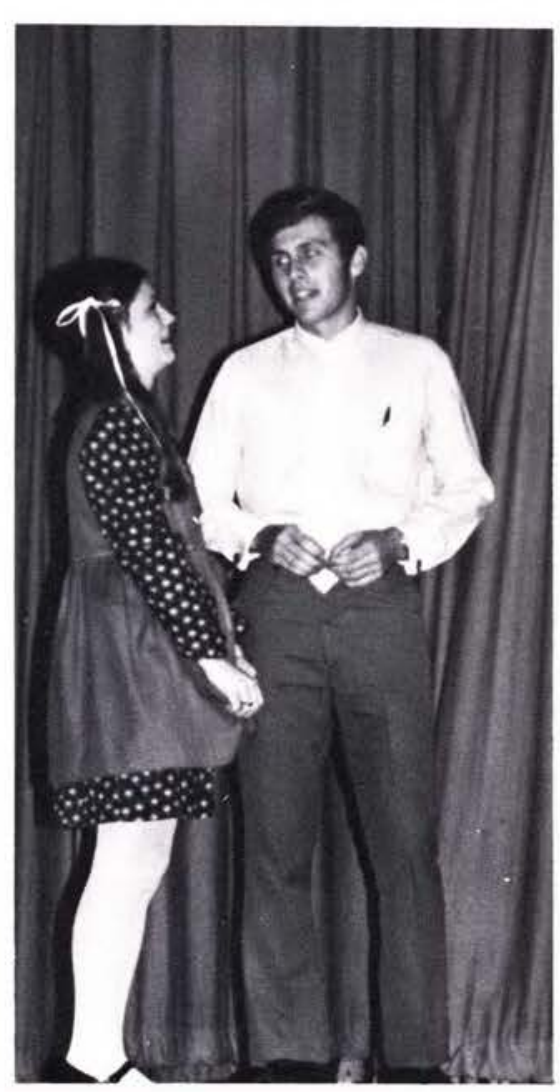



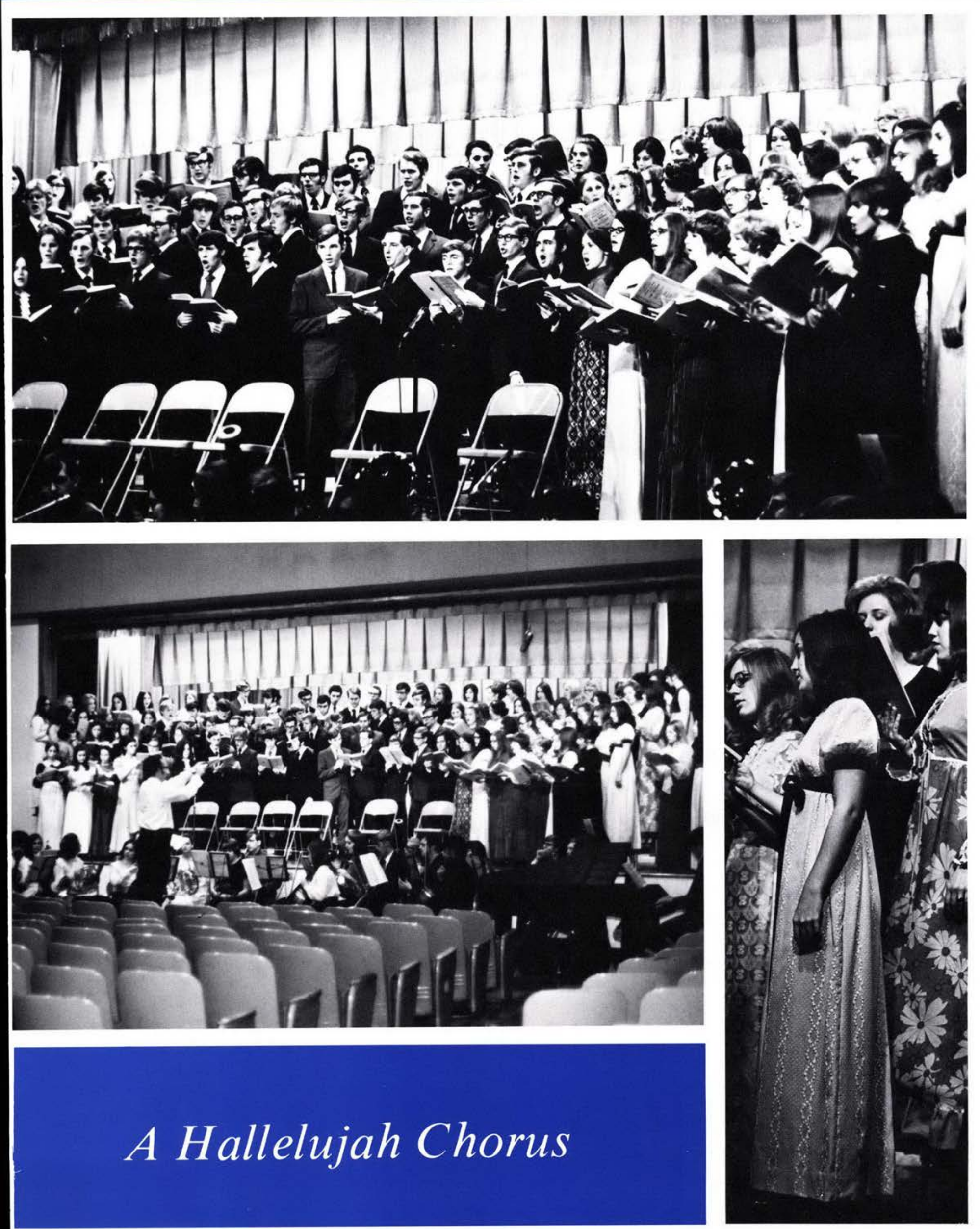

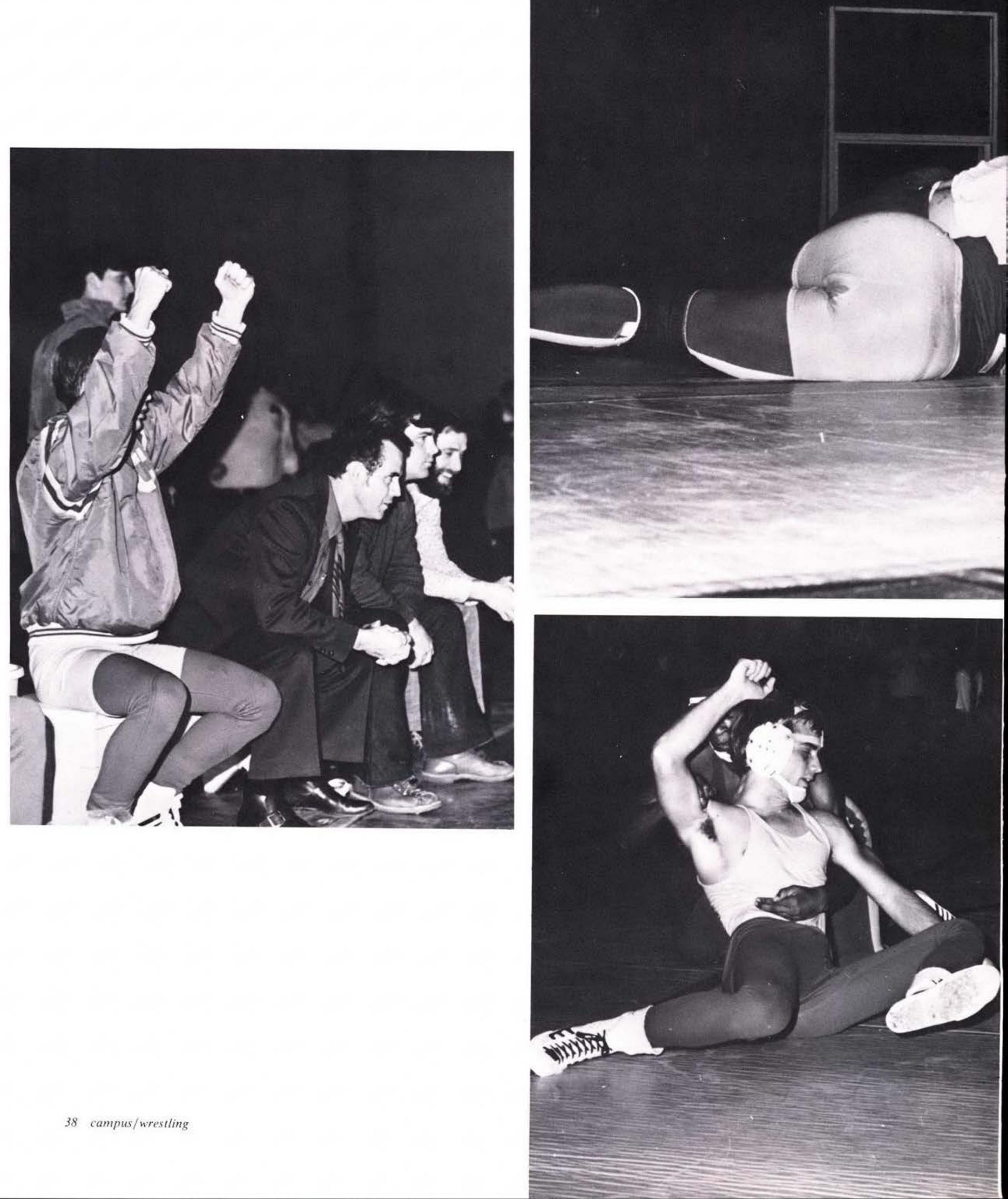

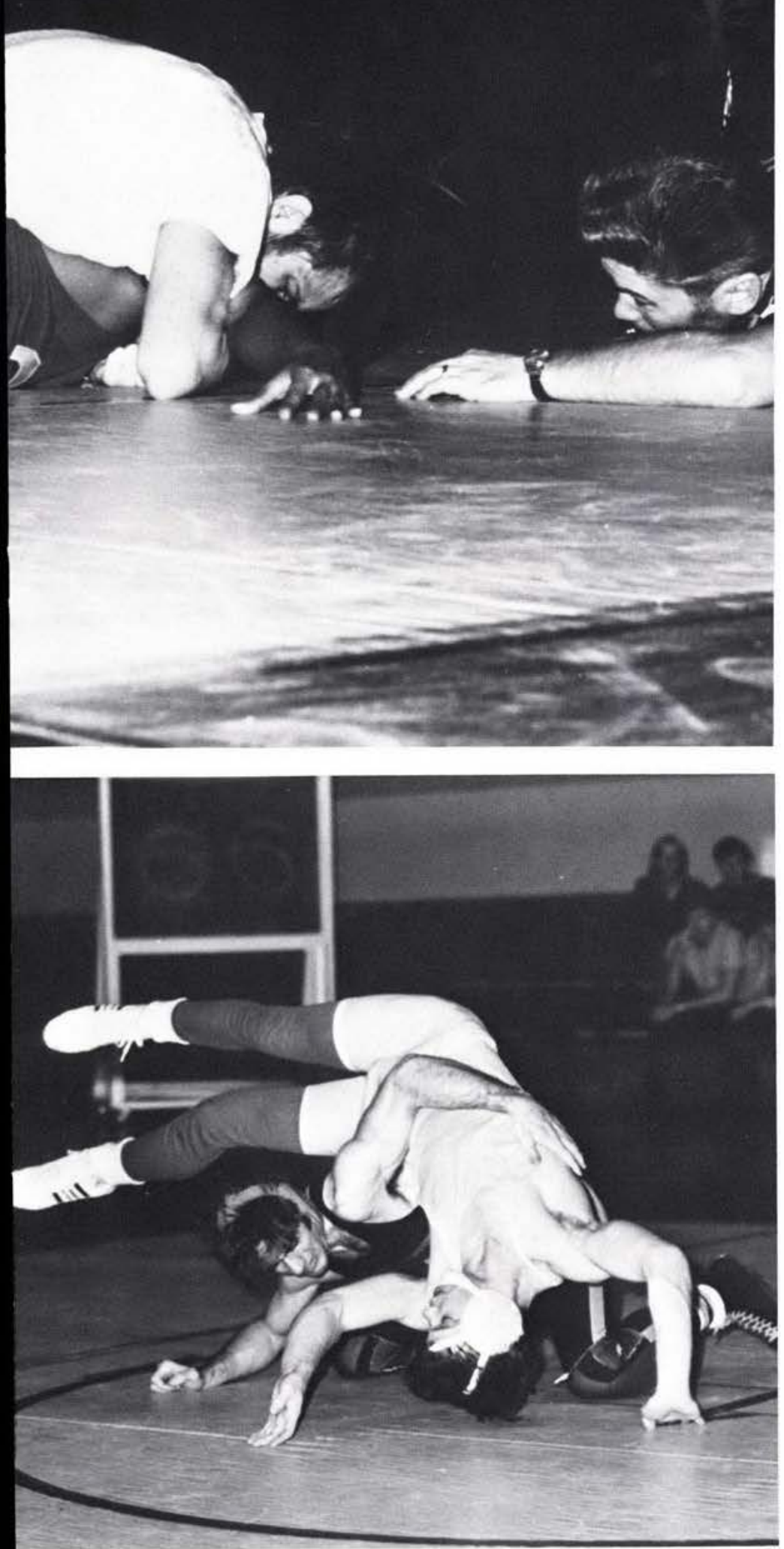

8 중y
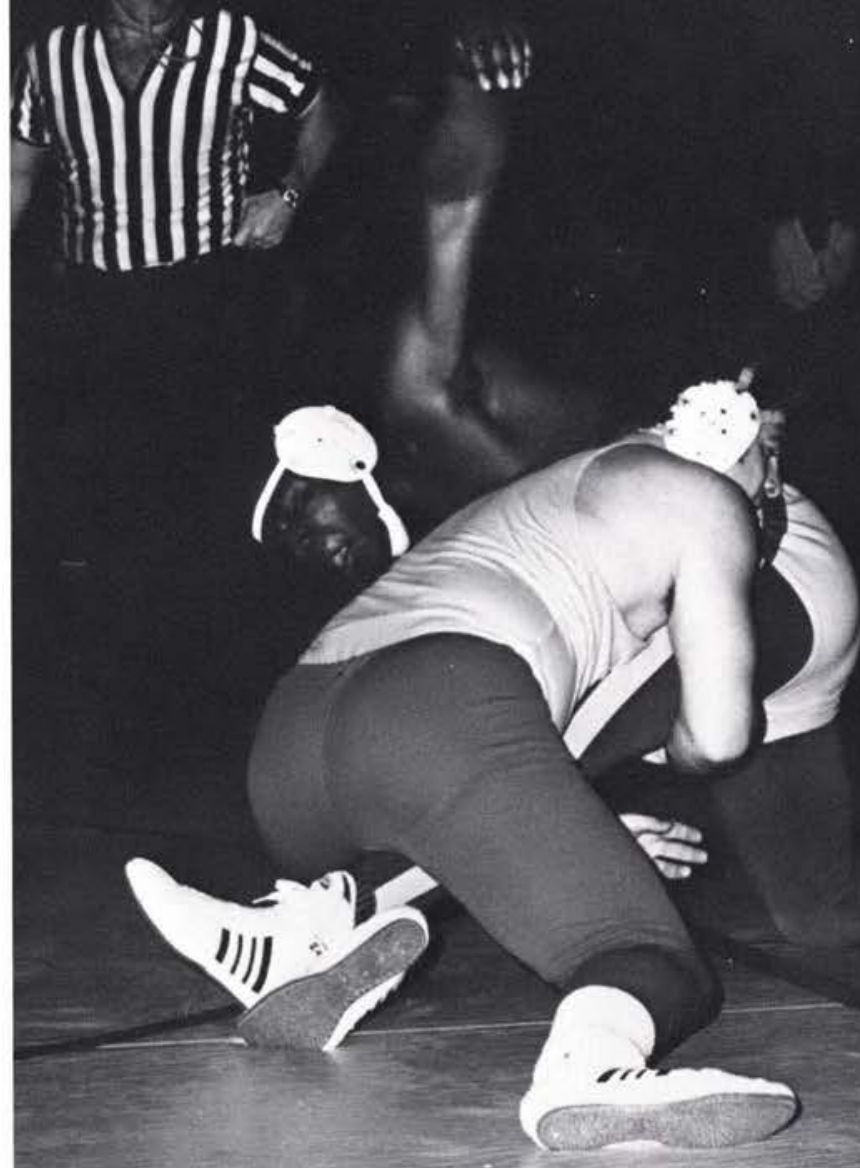

A young team

Two month's preparation

Fundamentals and basics

Two hours a night

Anticipation of another season

Pulling for a teammate

Shouting encouragement

A gym in GS 26

oh, for a room for the wrestling mats 

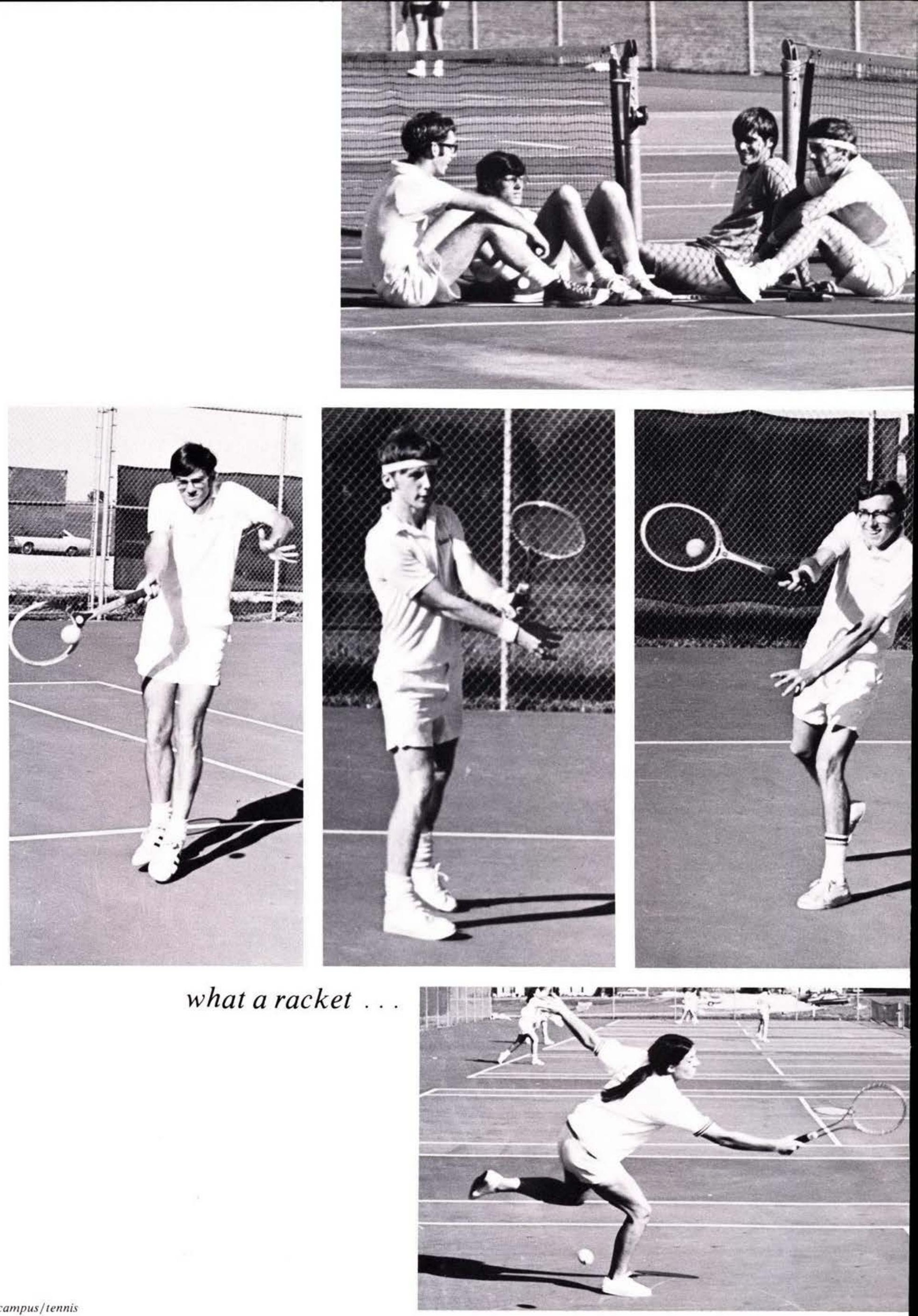

And it came to pass.

Early in the morning toward the last day of the quarter.

There arose a great multitude smiting the books and wailing

And there was much weeping and gnashing of teeth.

For the day of judgment was at hand.

And they were sore afraid, for they had left undone

Those things which they ought to have done

And there was no help for it.

And there were many abiding in the dorm

Who had kept watch over their books by night,

But it availed them naught.
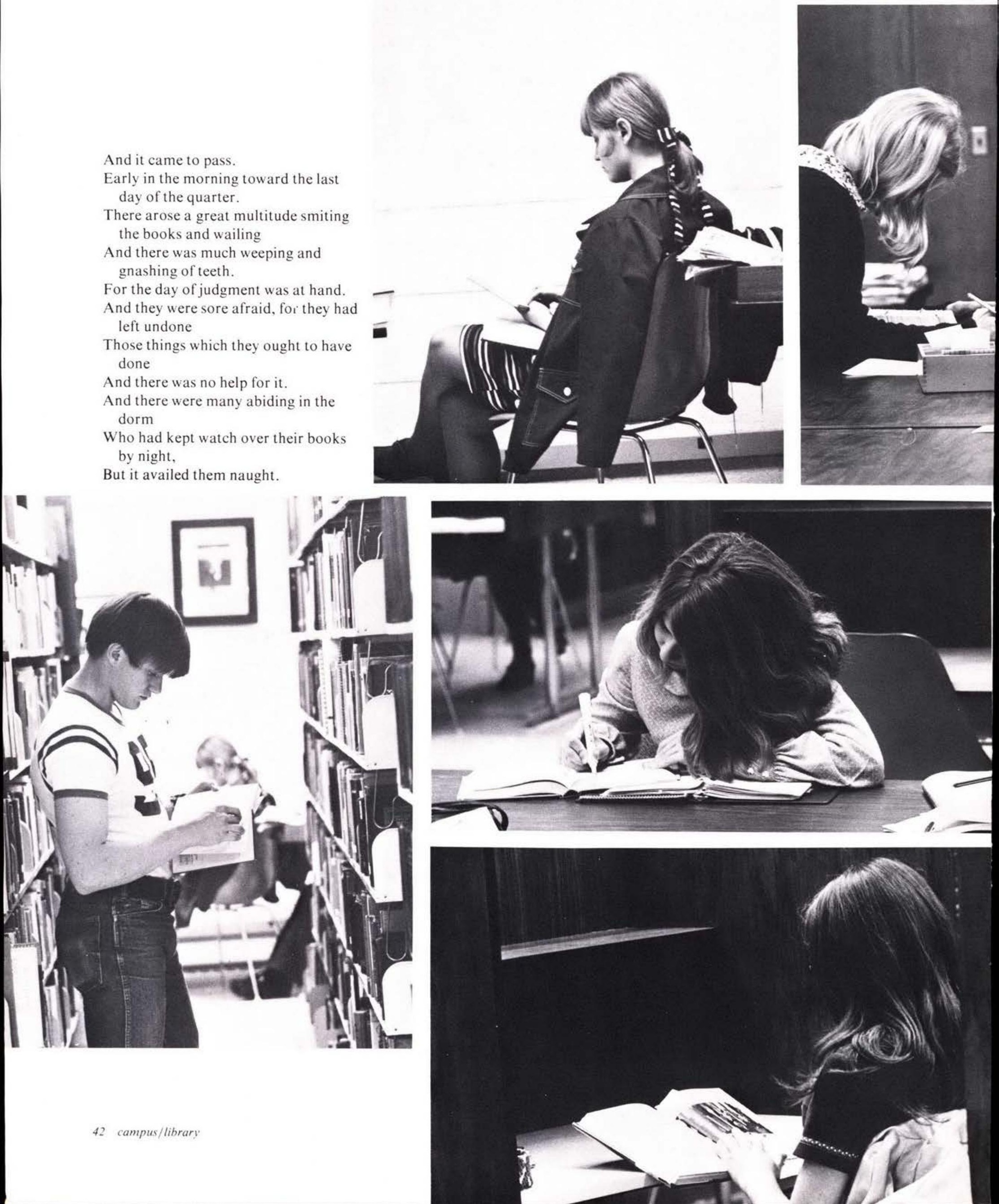

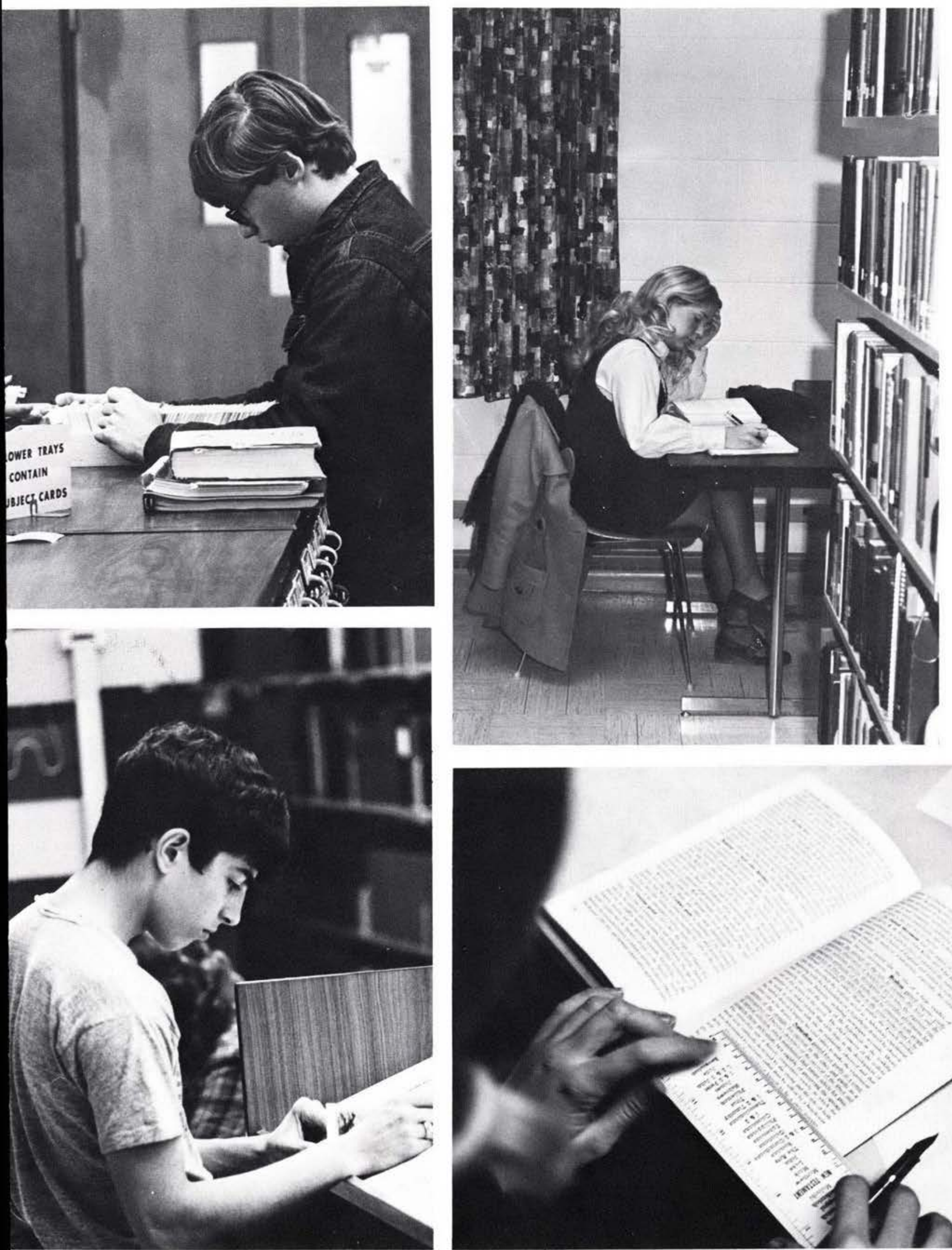

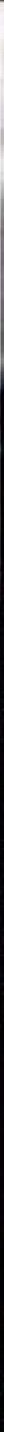

But some there were who rose peacefully, For they had prepared themselves the way And made straight paths of knowledge

And these were known as wise burners of the midnight oil

And to others they were known as "curve raisers." And the multitude rose and ate a hearty breakfast. And they came unto the appointed place And their hearts were heavy within them.

And they had come to pass, but some to pass out.

And some of them

Repented to their riotous living and bemoaned their fate, But they had not a prayer

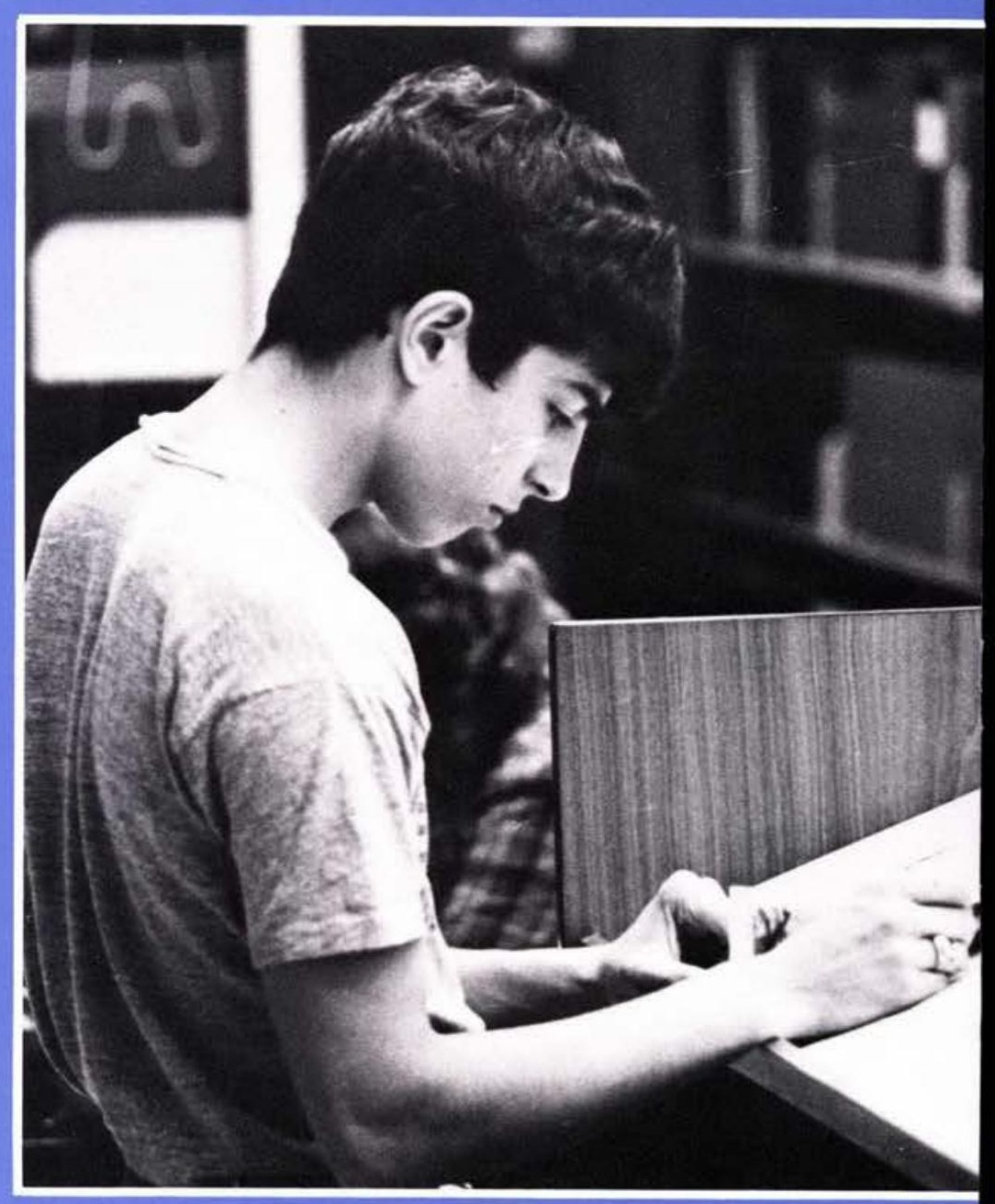



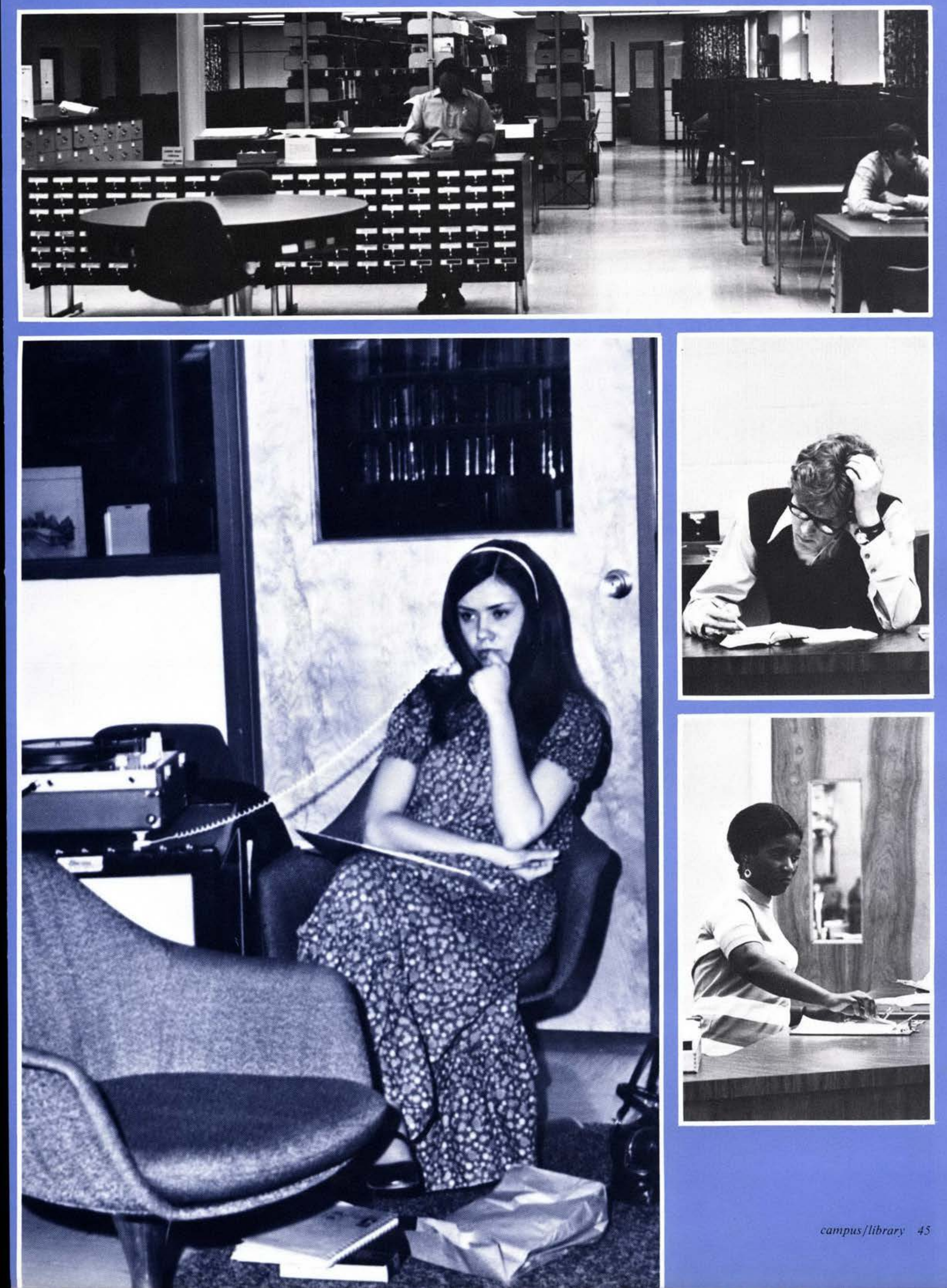


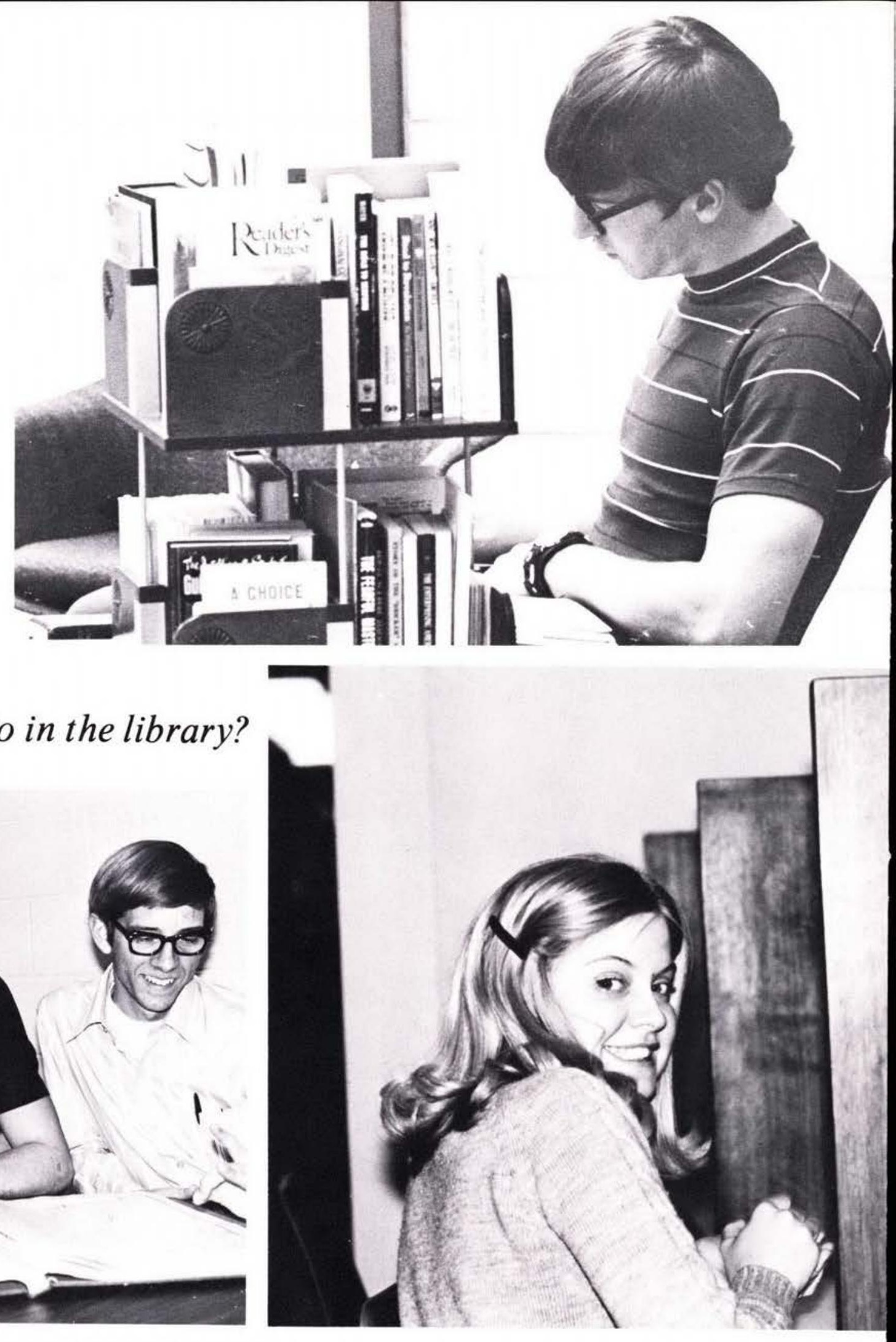

And at the last hour there come among them

One known as the instructor; and they feared exceedingly.

He was of the diabolical smile,

And passed papers among them and went his way.

And many and varied were the answers that were given,

For some of his teachings had fallen among fertile minds.

Others had fallen among the fallows, while others had fallen flat.

And some there were who wrote for one hour, others for two;

But some turned away sorrowful,

And many of these offered a little bull

In hopes of pacifying the instructor.

And these were the ones who had not a prayer,

And when they finished they gathered up their belongings.

And went their way quietly, each in his own direction,

And each vowing unto himself in this manner;

"I shall not pass this way again." 


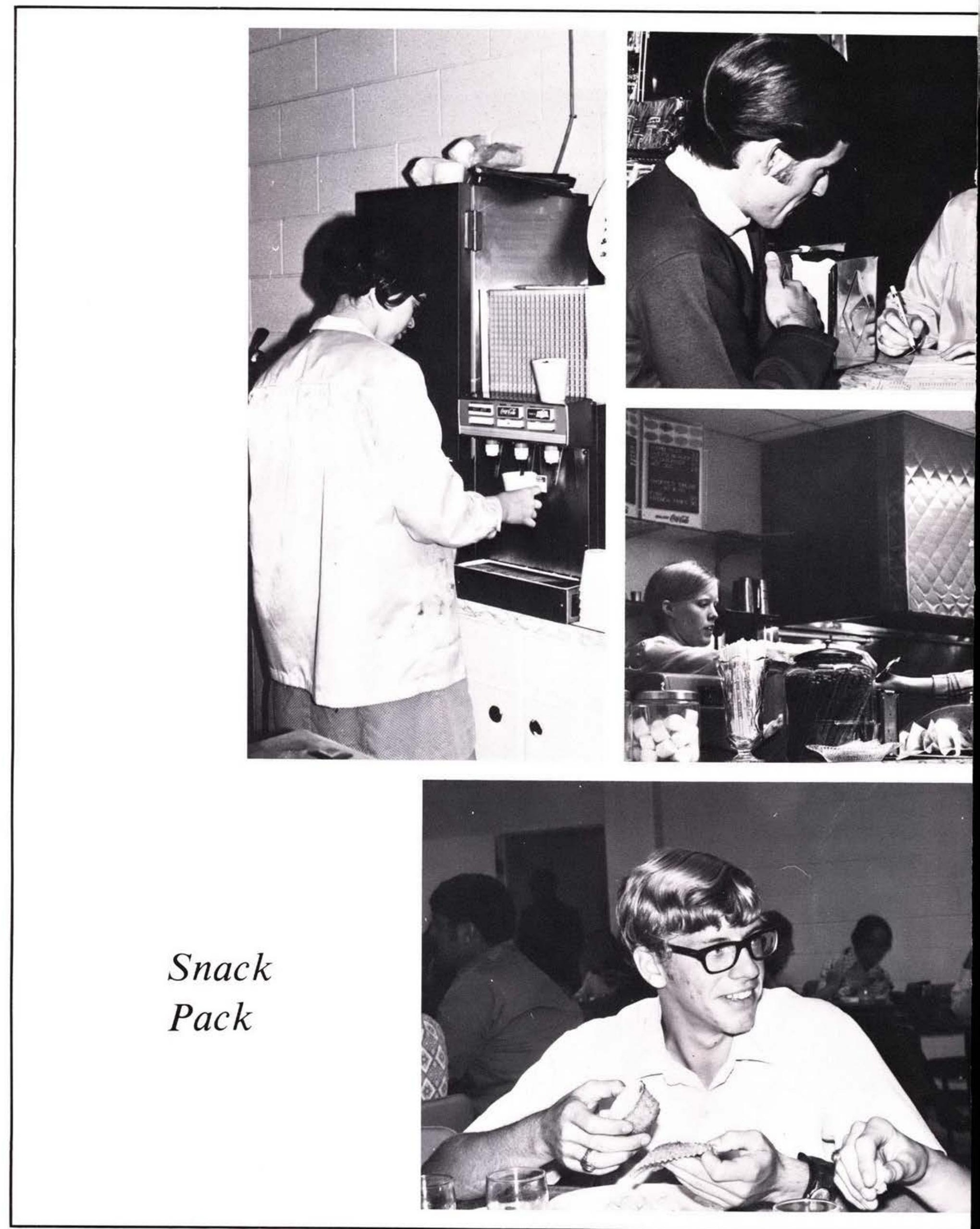



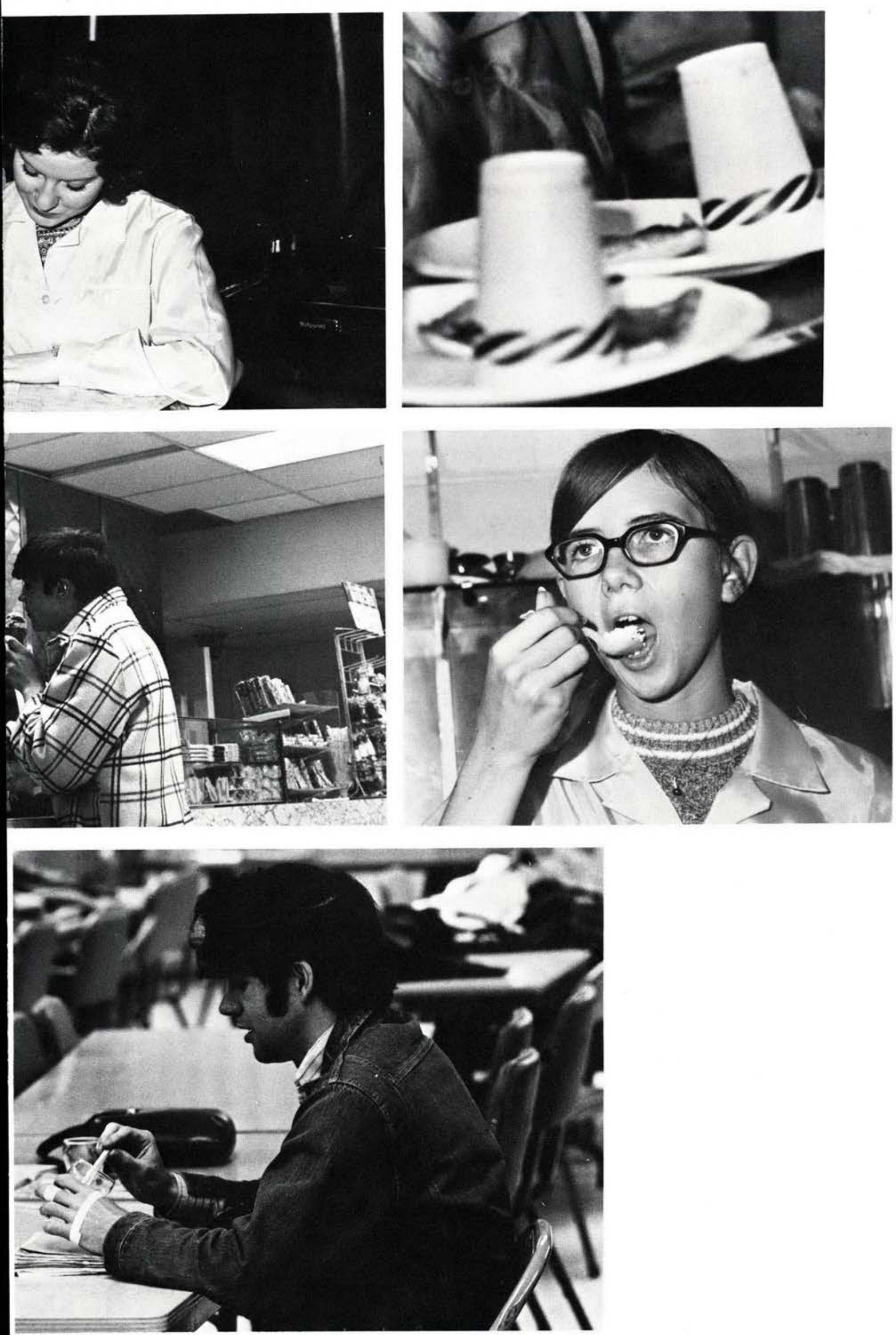
JACKETS GOT

THAT POW'R

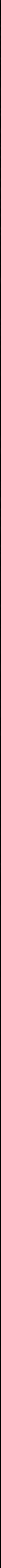




\section{$U G H !$}

\section{IIEN}

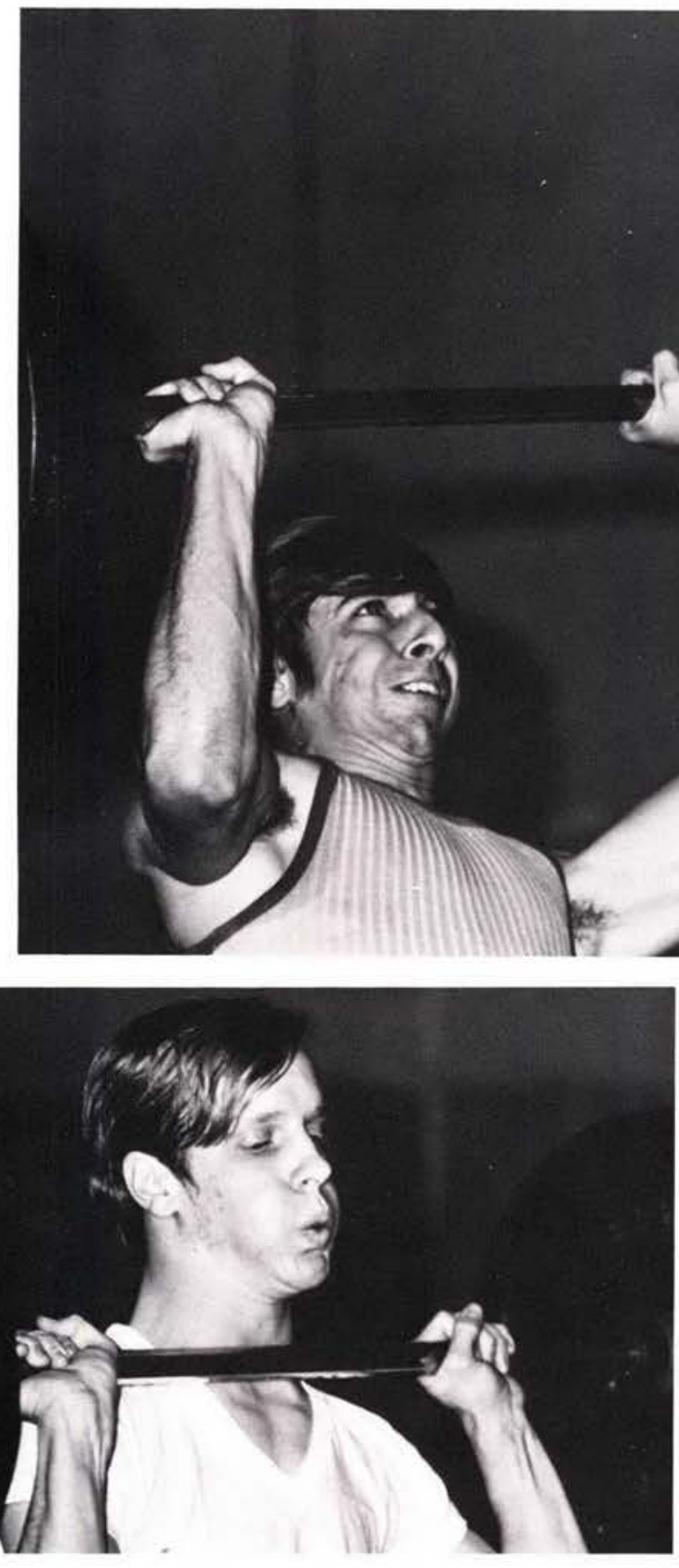

52 campus/candids

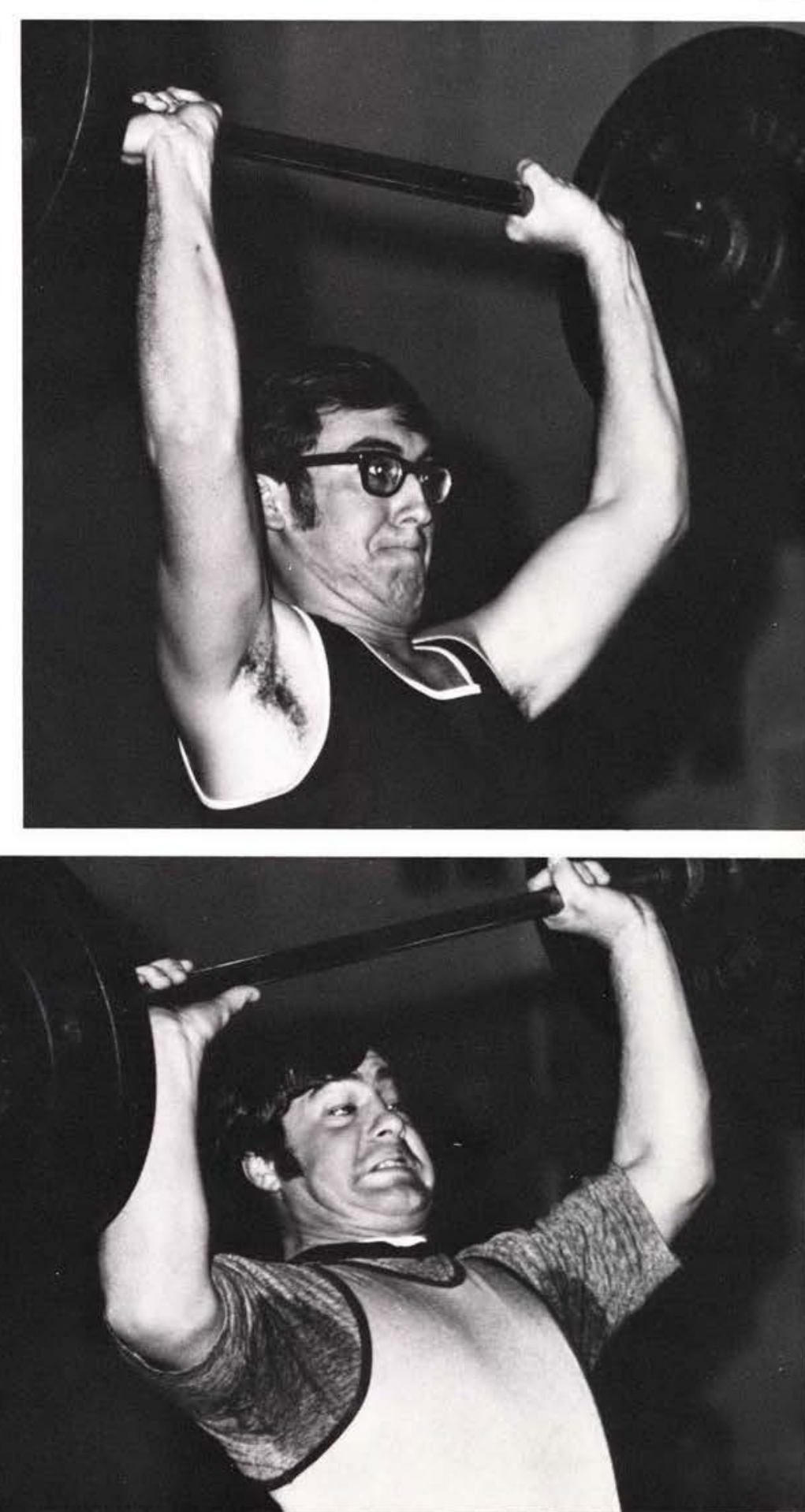



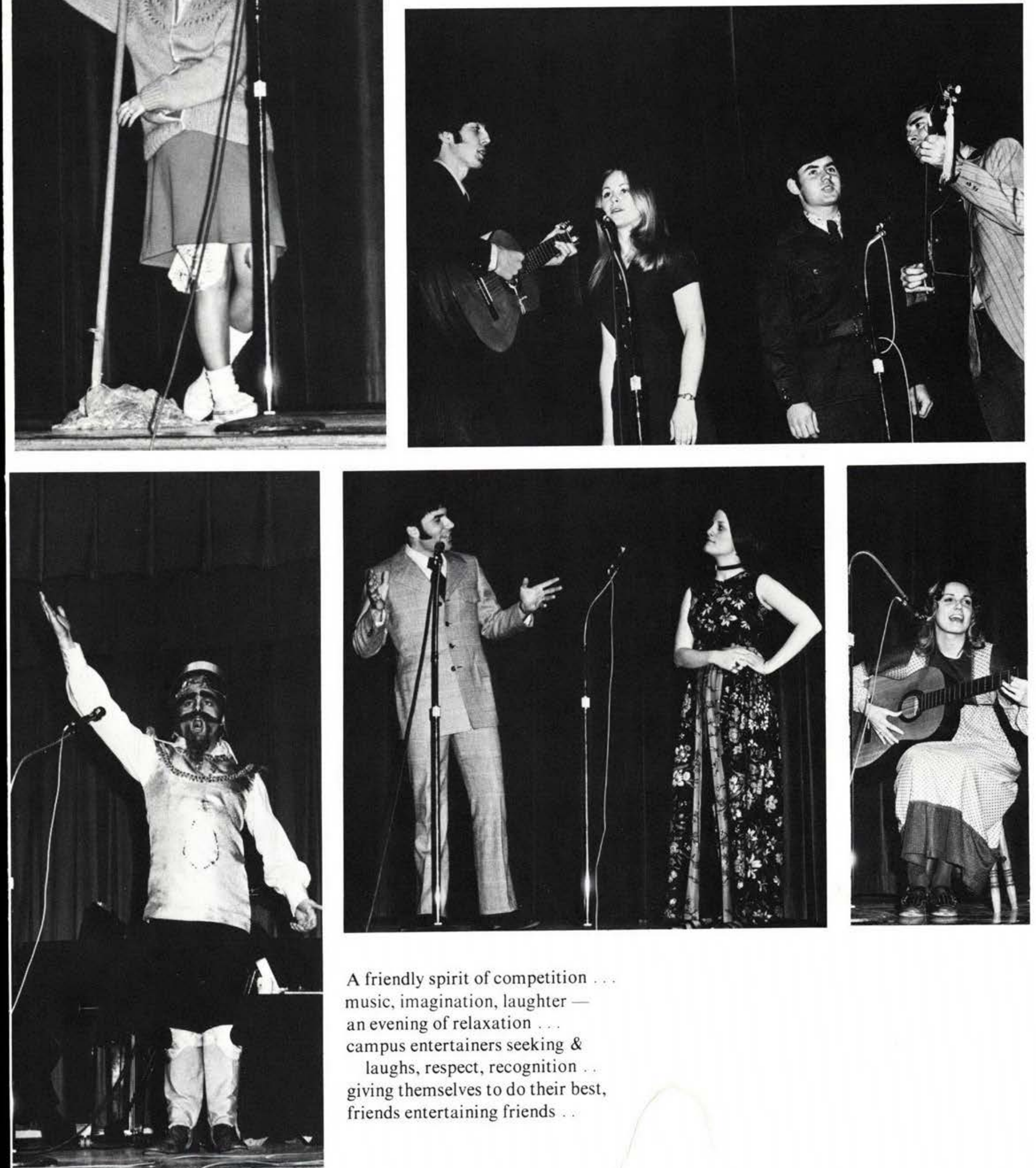

A friendly spirit of competition music, imagination, laughter an evening of relaxation ...

campus entertainers seeking \&

laughs, respect, recognition

giving themselves to do their best,

friends entertaining friends 


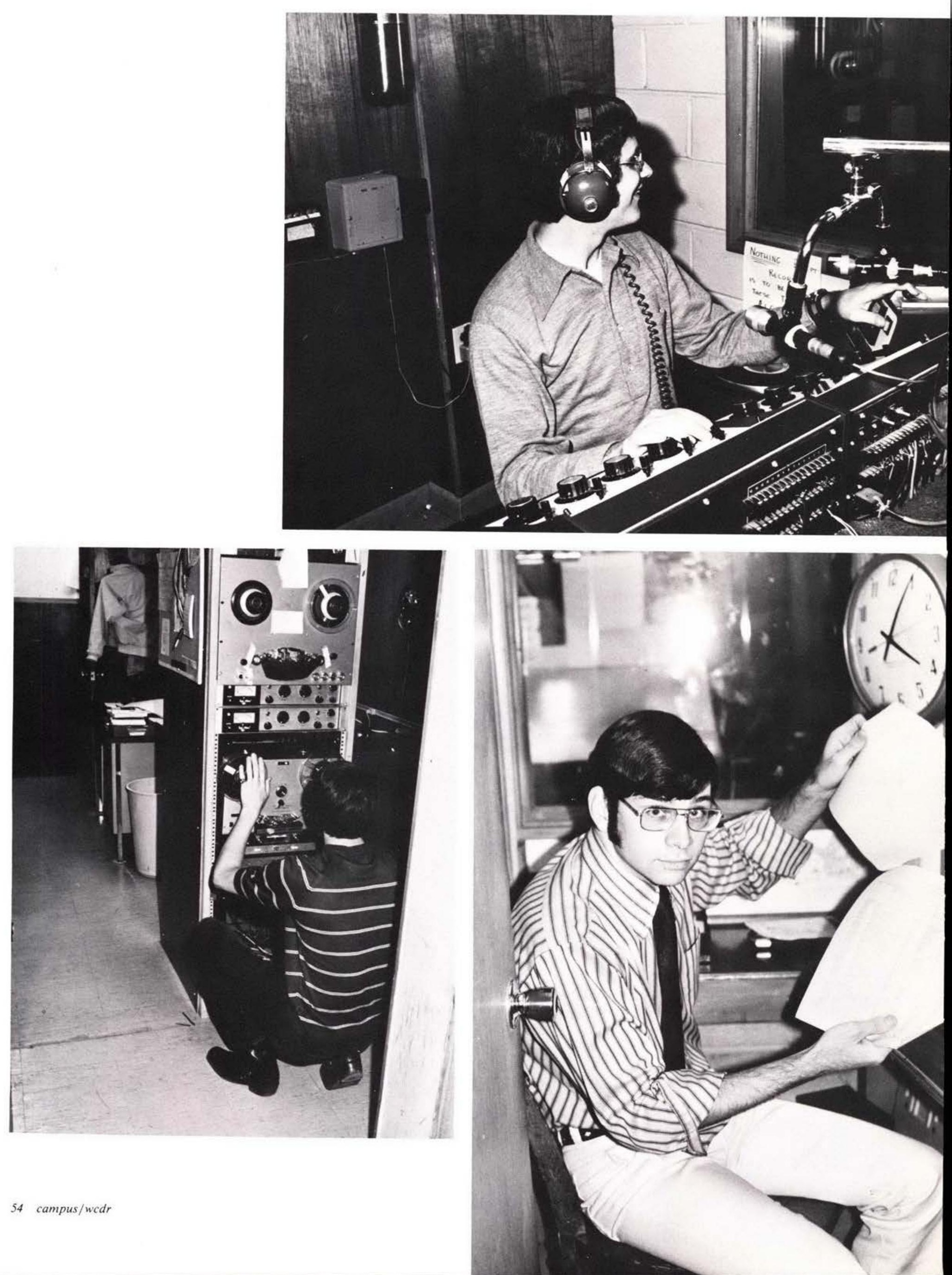


pick'n 'em up and put'n 'em down ...
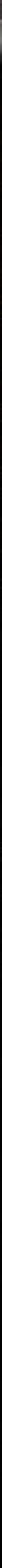

a cold-rainy day, but spirits were high ... students en masse - a goal that must achieved .... a route to follow pausing to rest or fix a shoe .... some with a fourlegged friend, some in wheel chairs - they all came looks of wonder and amazement as we passed by, a call of, "What are you protesting?" and one left the ranks to share our Christ ... dampened spirits by lunch time - and some left, but $60 \mathrm{kept}$ on and reached the end - triumphant in their goal ...16 miles ... but the fellowship was great that's enough to walk for ... but $\$ 40,000$ came and our legs earned money for projects of the student body .... another example of our unity in One - Christ

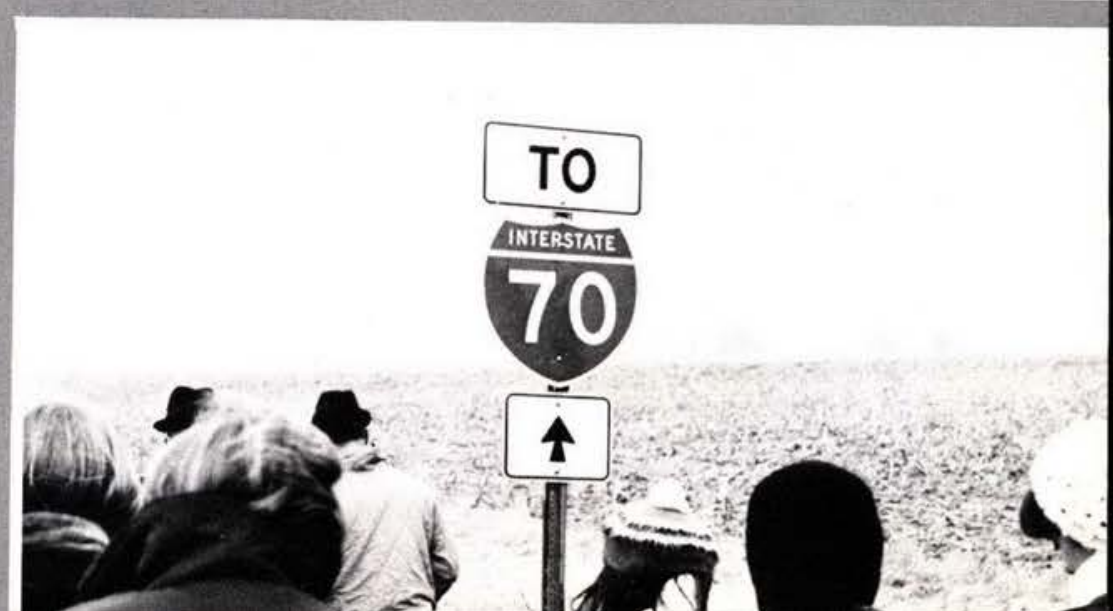




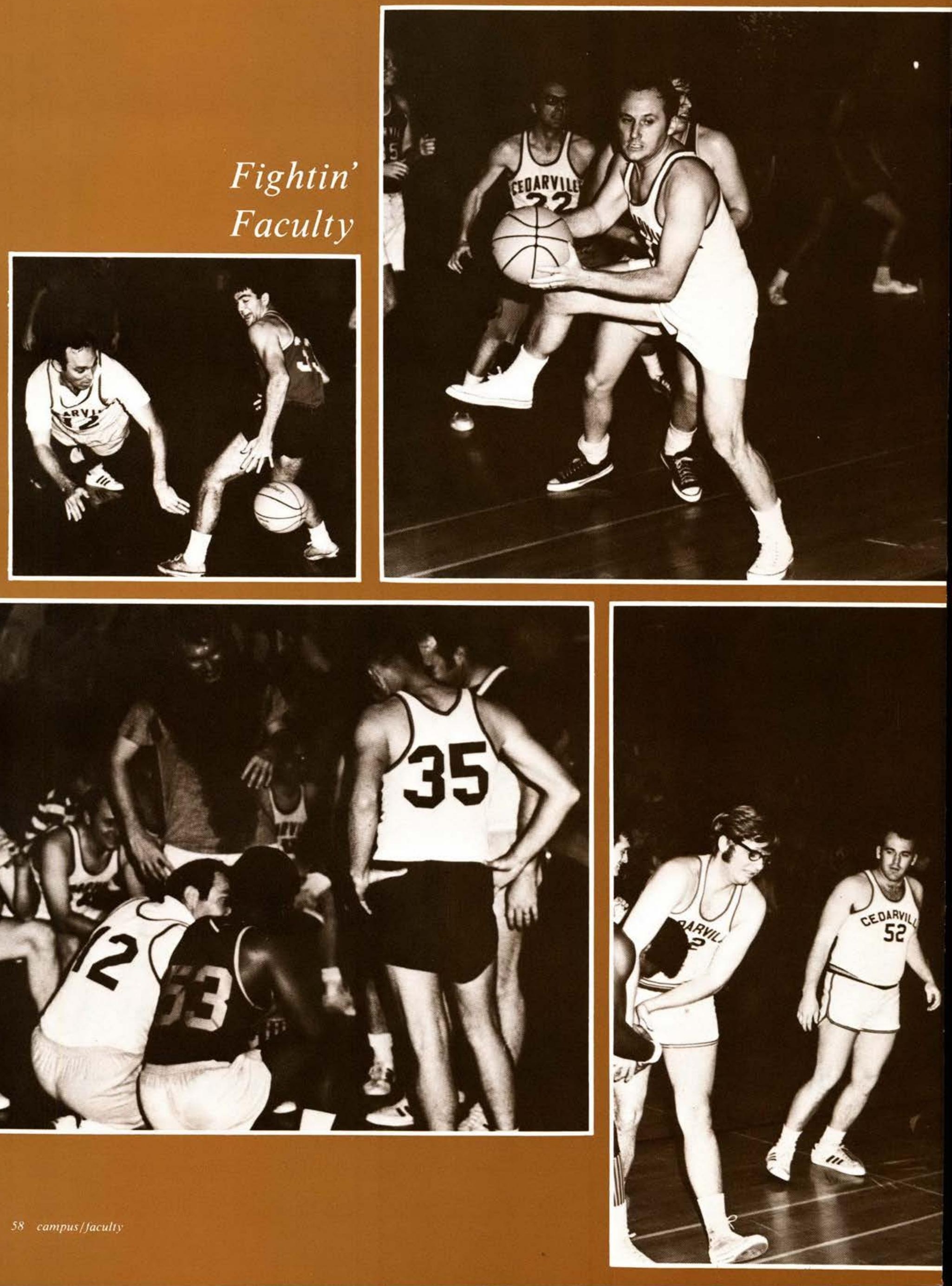




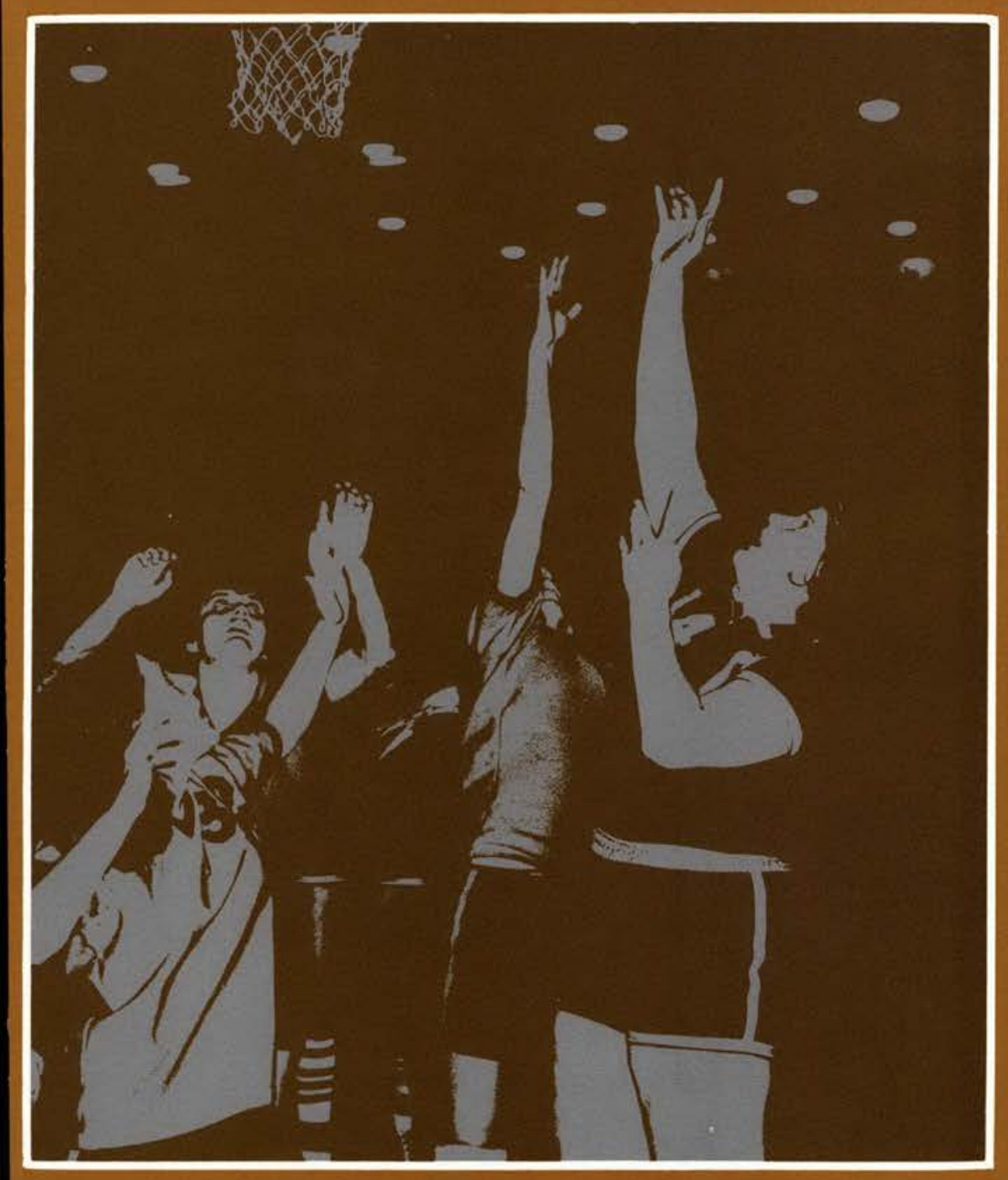

State Champs at work
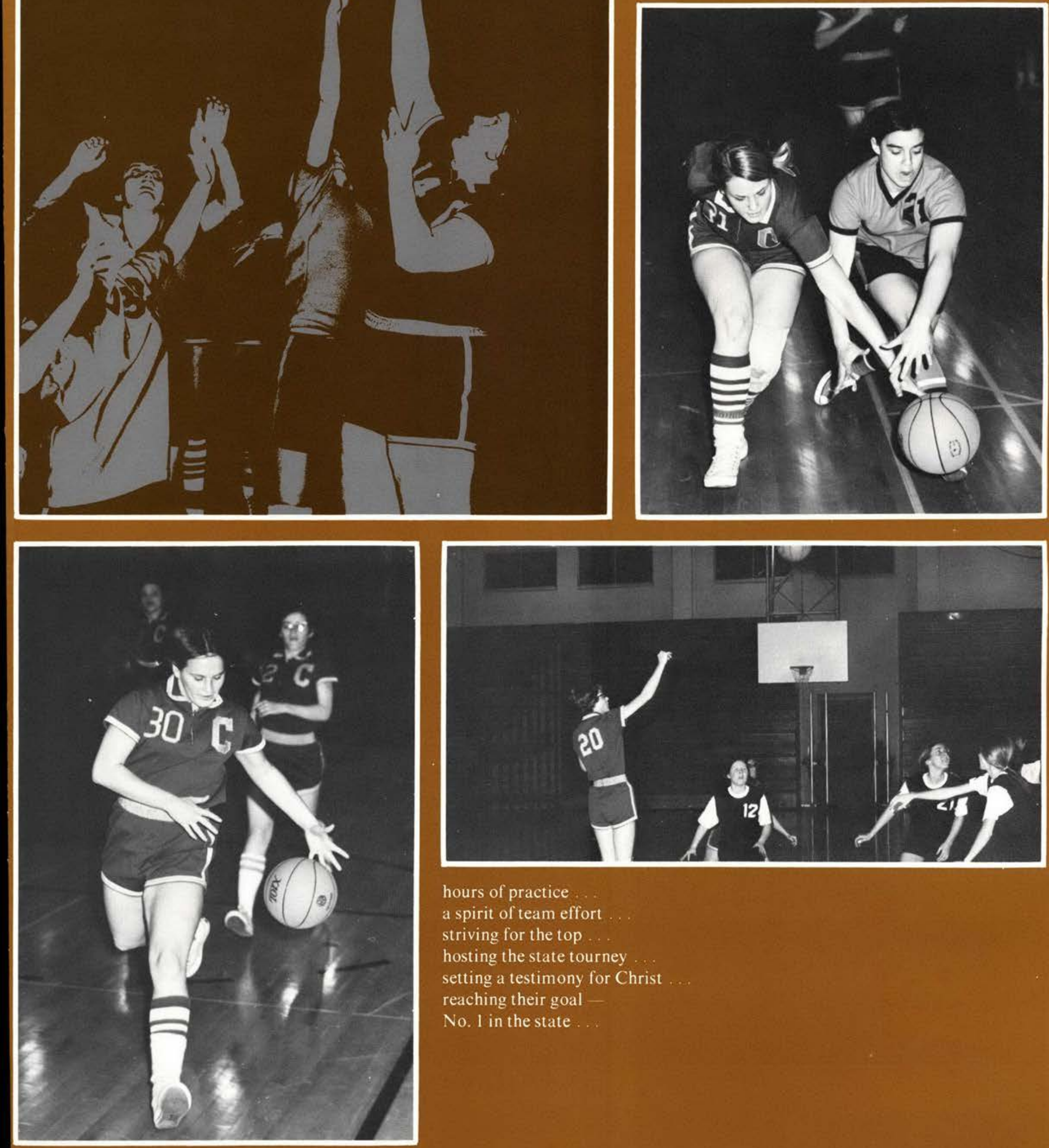

hours of practice

a spirit of team effort

striving for the top

hosting the state tourney

setting a testimony for Christ

reaching their goal -

No. 1 in the state 

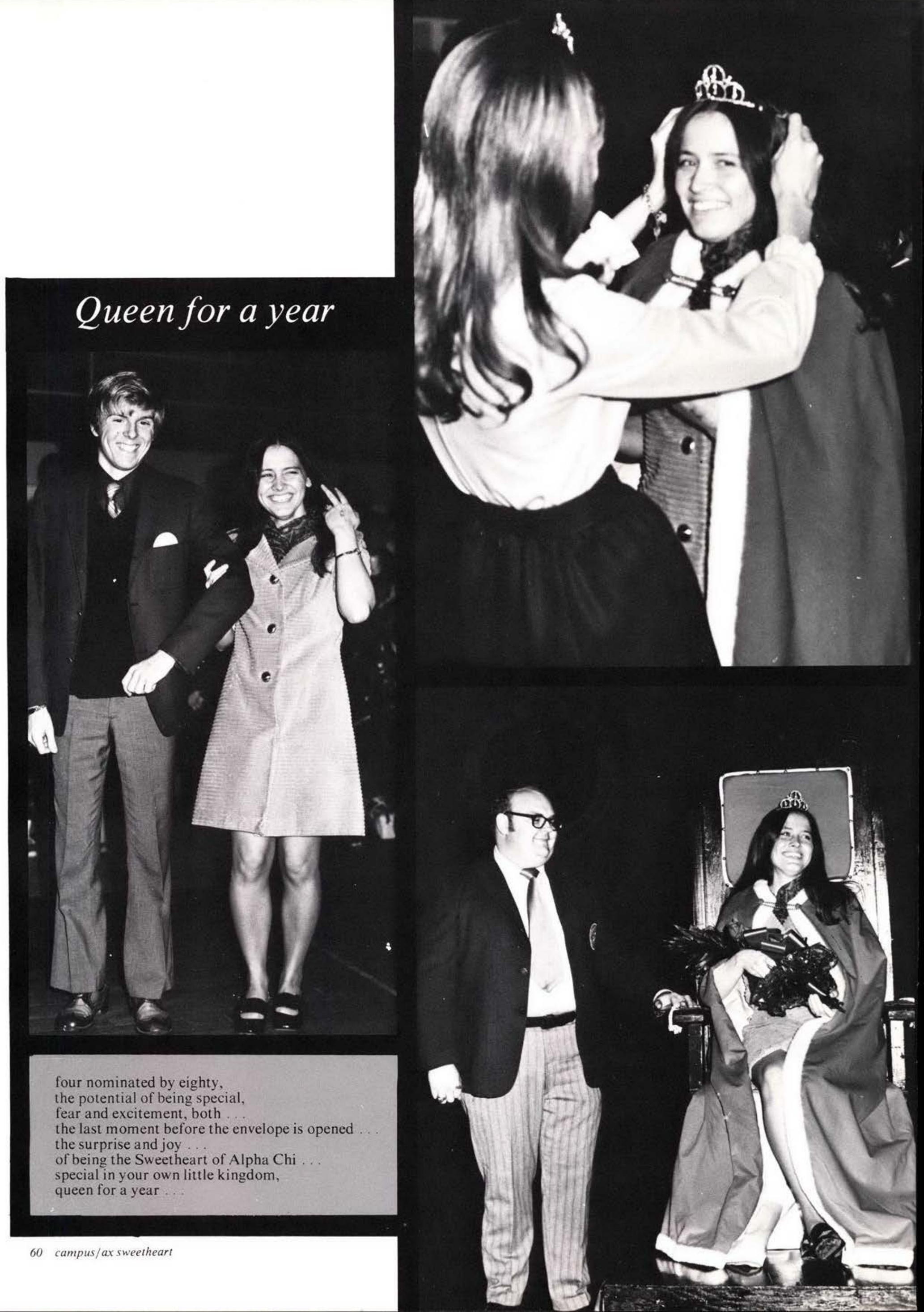


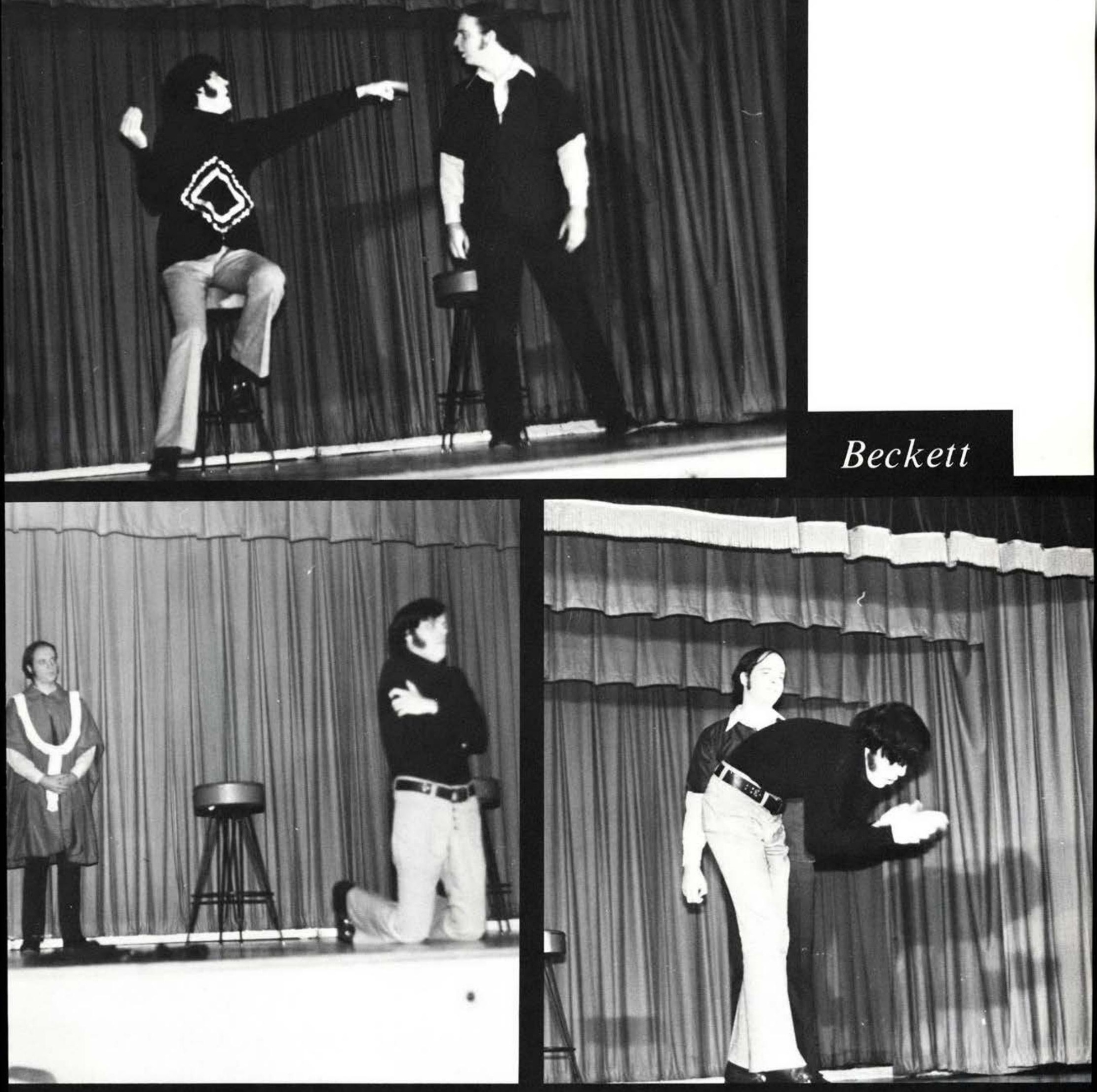


Osh Kosh B'gosh
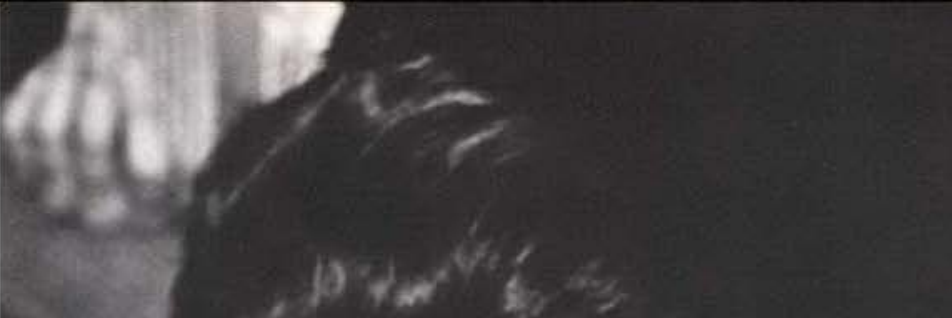

8
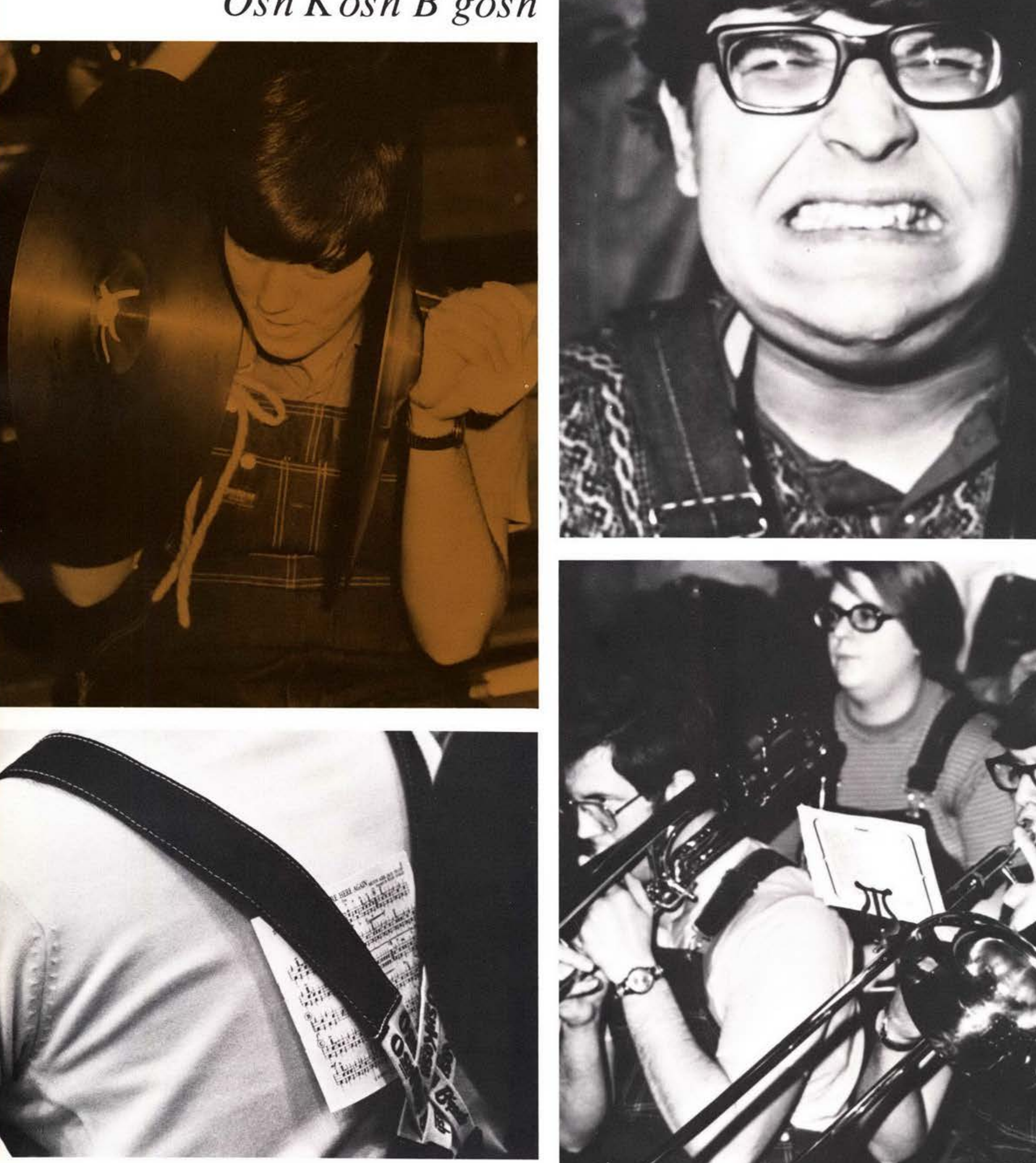

ic)
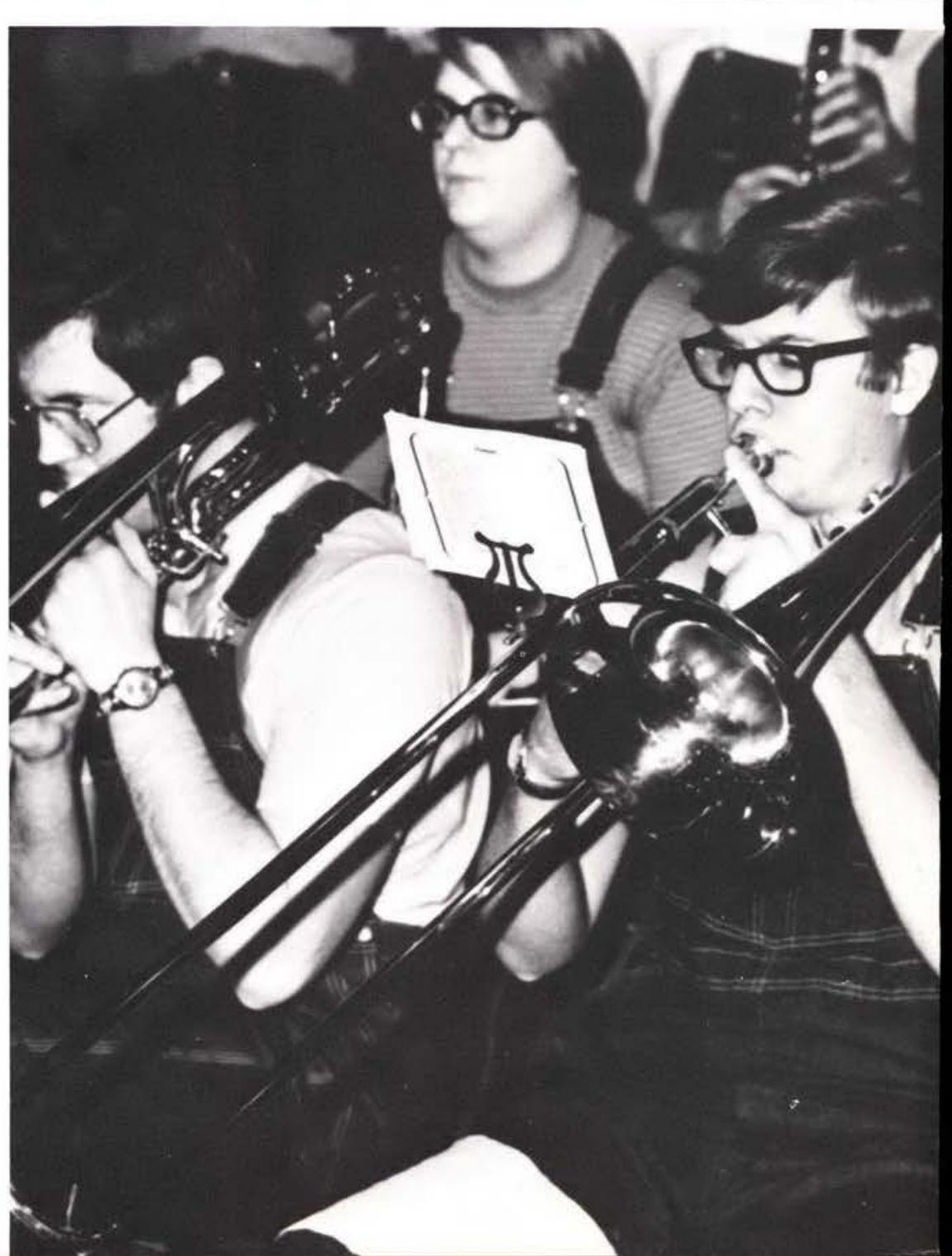


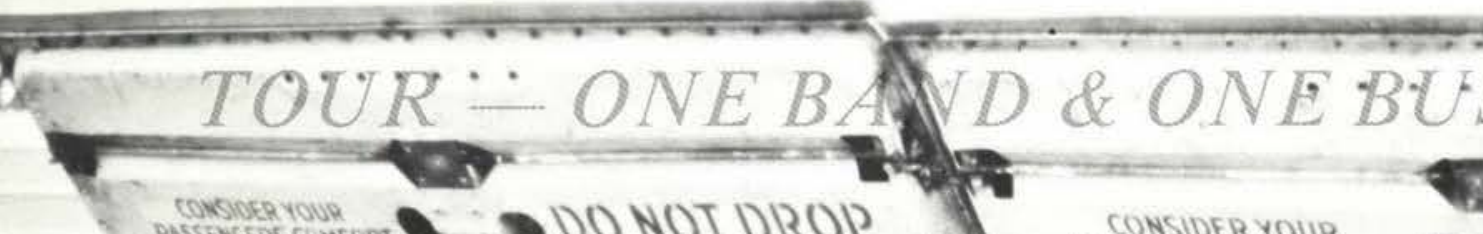

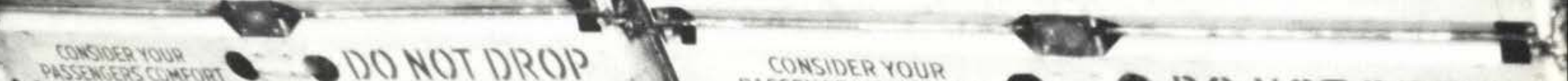
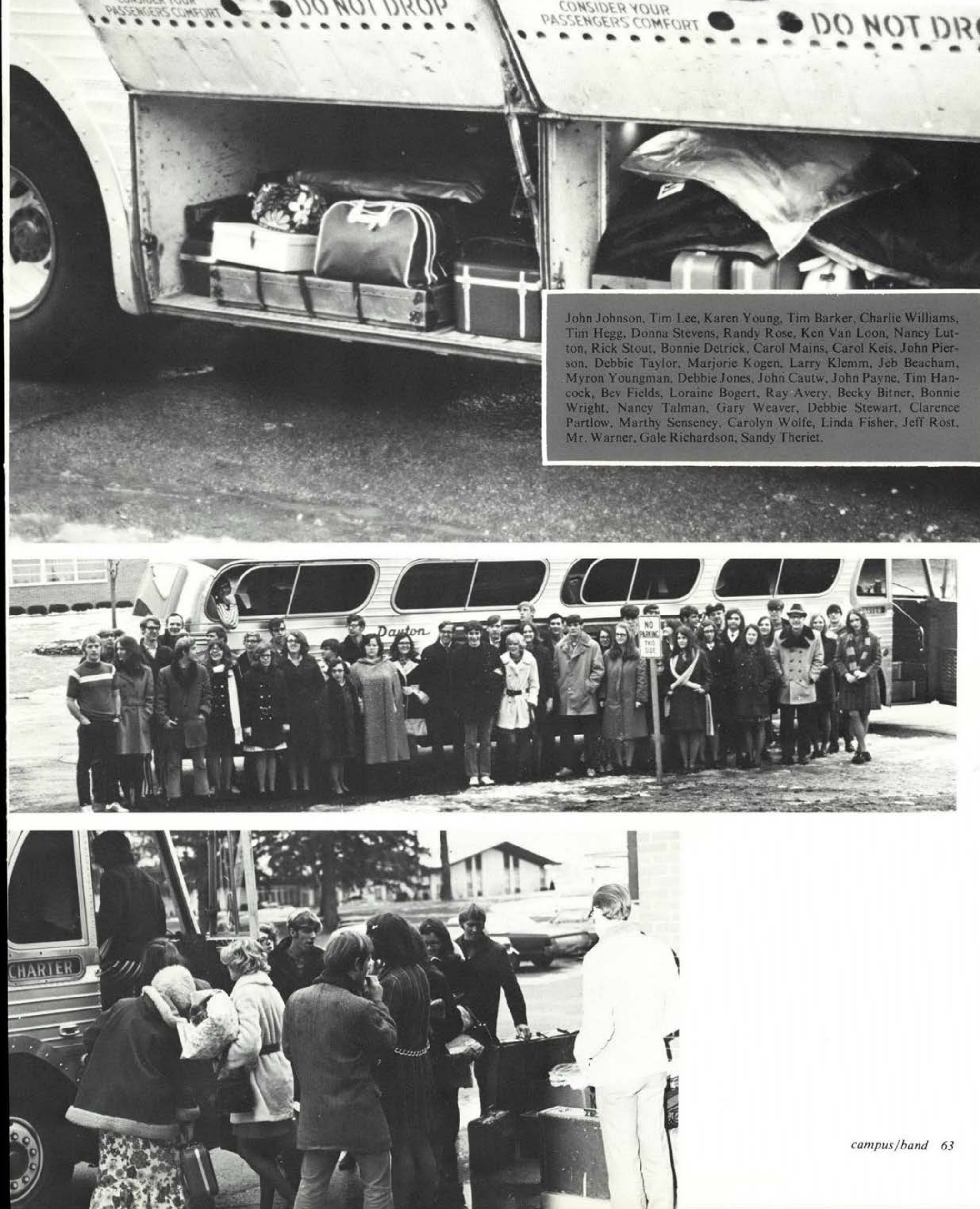

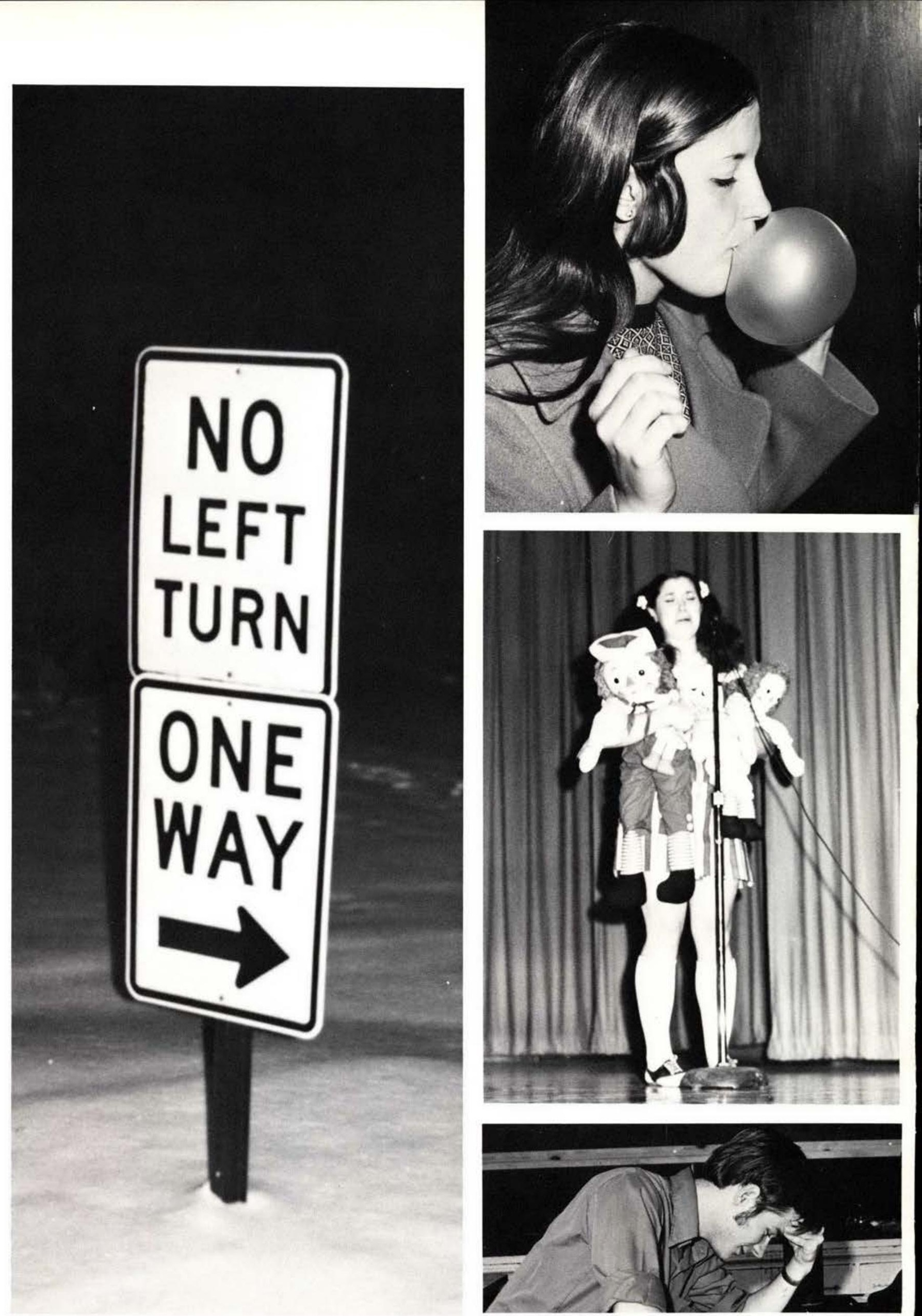

when college pressures get too much 

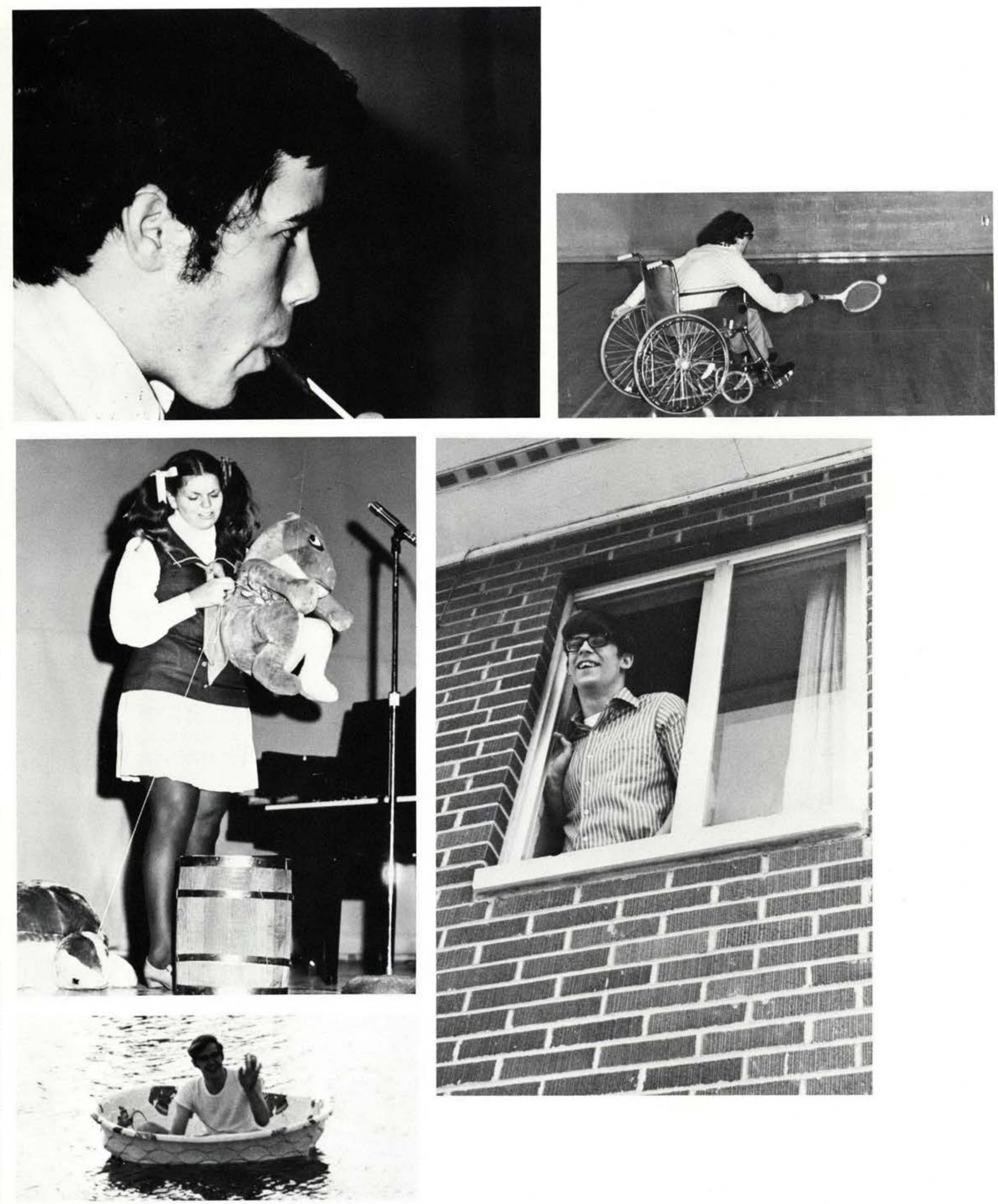

. . just . . 


\section{Beach Evangelism}

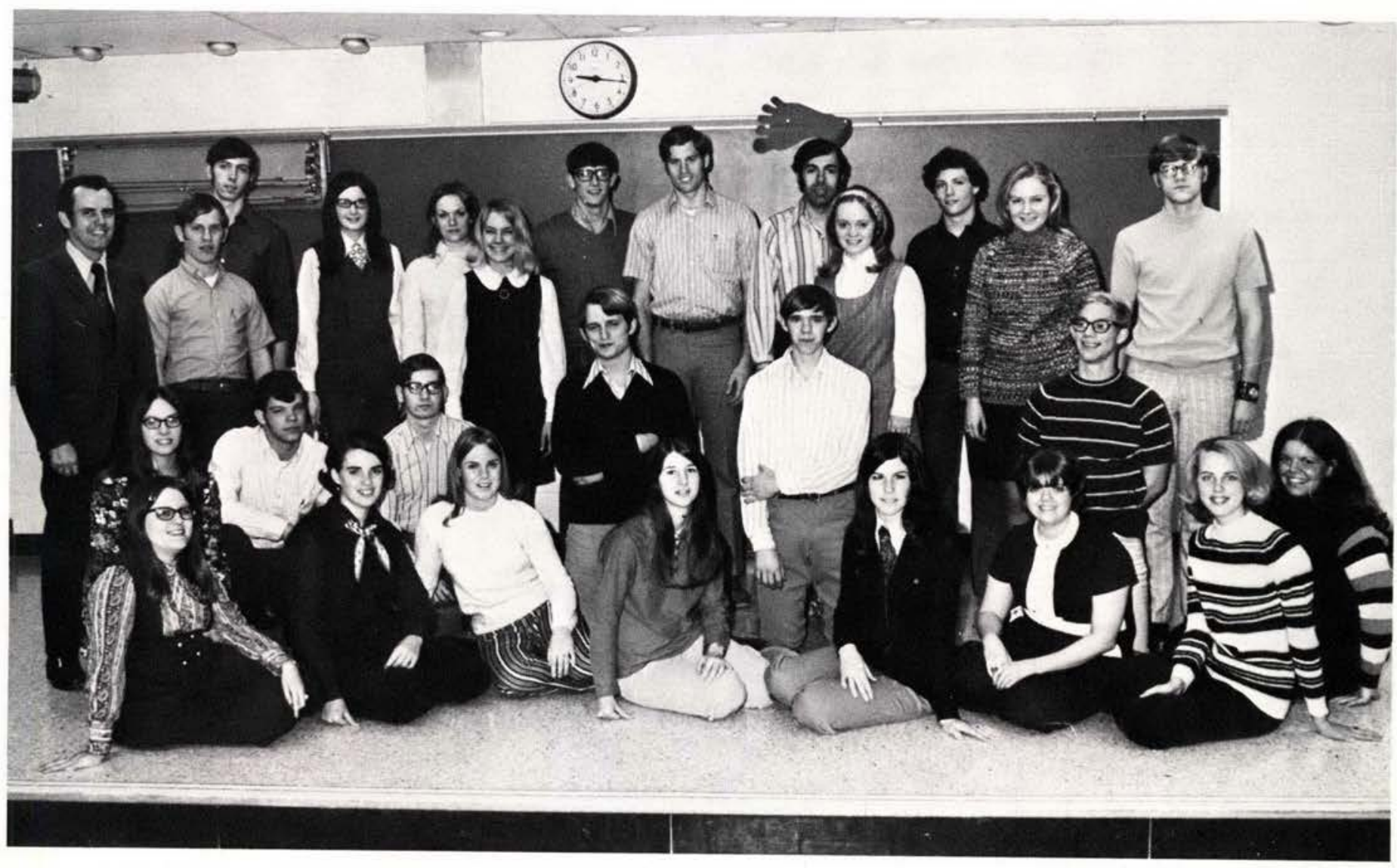

Row I: Joyce Self, Debbie Davis, Kathy Burkhart, Joyce Mohler, Yvonne Cope, Ellen Young, Becky Anderson: Row 2: Sherlyn Hansen, Bob Bvcraft. Dale Fogle, Dale Schilling, Randy Rose, Ken Van Loon, Becky Kimble: Row 3: Pastor Green, Jake Tipton, Marquitta Kittner. Sue Moore. Janet Long, Terry Mudder: Row 4: Harry Phillips, Marion Scharmenn, Shirley Rocher, Rich McGee, Terry Clap, John Perierra, Alan Dunn.

Thousands of people decorated the beach ...

College kids from across the states enjoying the sun and sea ...

Others there - existing ...

A handful of concerned people ready and willing to share their Lord

A goal for beach evangelism. 


\section{MISSIONARY CONFERENCE}
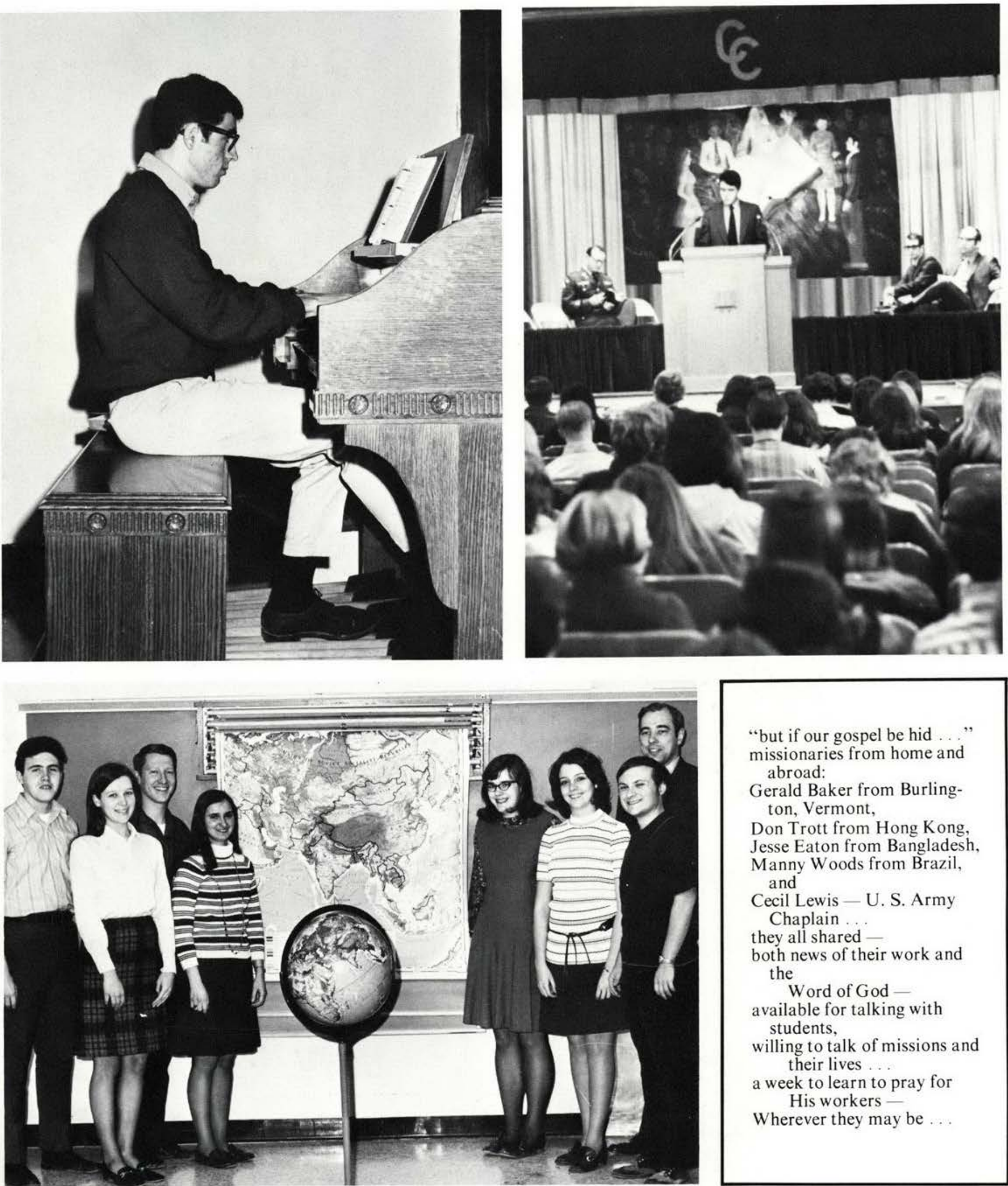

"but if our gospel be hid ..." missionaries from home and abroad:

Gerald Baker from Burlington, Vermont,

Don Trott from Hong Kong, Jesse Eaton from Bangladesh, Manny Woods from Brazil, and

Cecil Lewis - U. S. Army Chaplain

they all shared -

both news of their work and the Word of God available for talking with students,

willing to talk of missions and their lives

a week to learn to pray for His workers -

Wherever they may be 


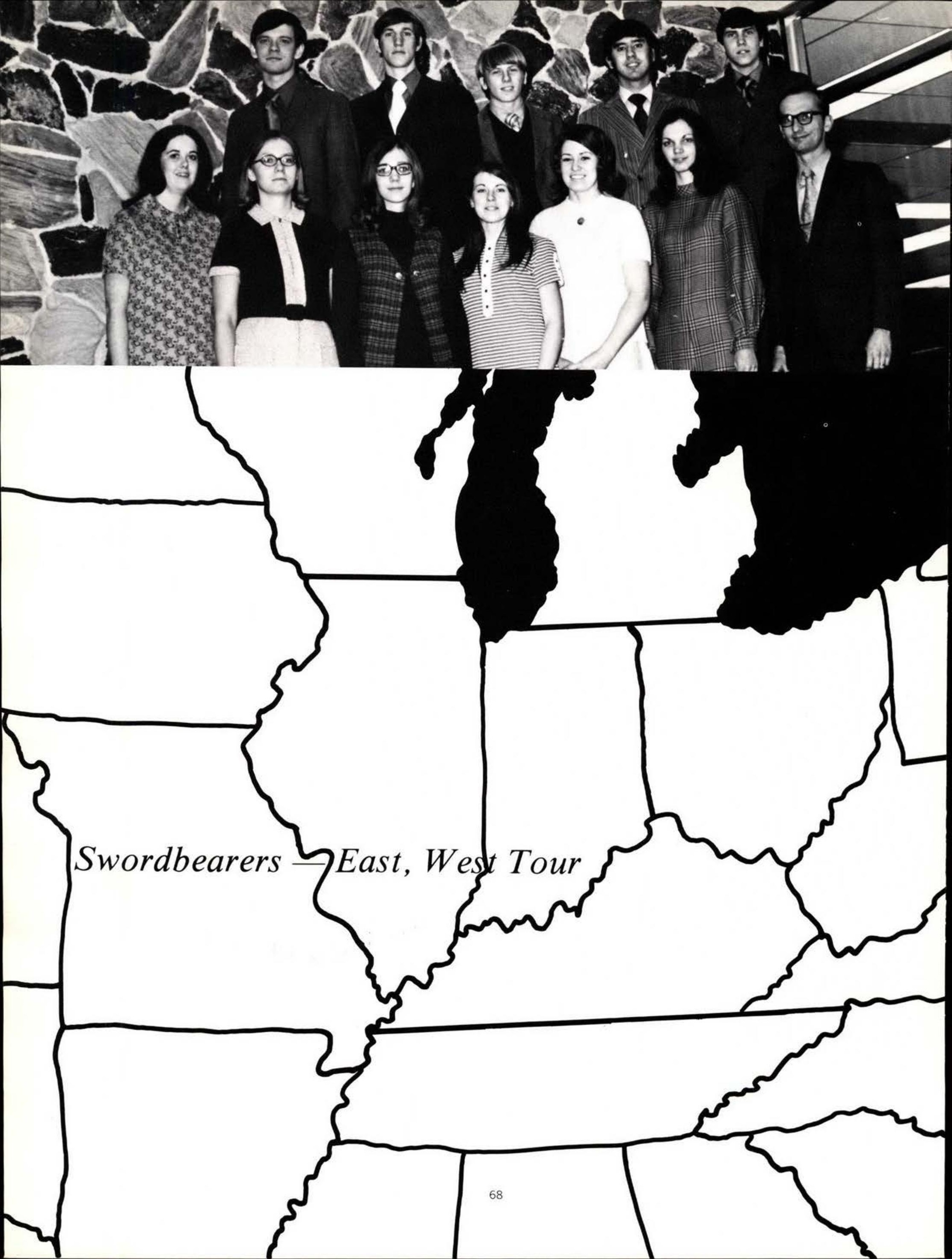


Row 1: Barb Fiest, Pat

Riley, Sharon Gazdik,

Kathy Strawn, Becky Lamb, Sharon Gillogly,

Henry Phillips; Row 2: Paul Radcliffe, Bill Tobias, Larry Strawn, Al Konya, John Bratcher.
Serving the Savior they went forth singing songs and giving testimony to those seeking salvation; spreading the Word on spring vacation SWORDBEARERS WEST
Row 1: Carol Bierbaum, Becky Canine, Lyle Miller; Row 2 Stan Seevers, Pete Lillback Suzanne Hale, Debbie Sue Jones, Row 3: Merla Hammack. Bruce Klett; Row 4: Sue Selden, Dennis Twigg. Dan Thompson. traveling 1500 miles

sharing Christ with churches in discussions,

in presentations,

\section{in music,}

and for little people -

a puppet stage and Mertz

Snetz,

a testimony left in homes

a love in many hearts

new friends found and lost,

twelve in a van -

who learned to appreciate each other and God

a wonderful way to spend

spring

vacation

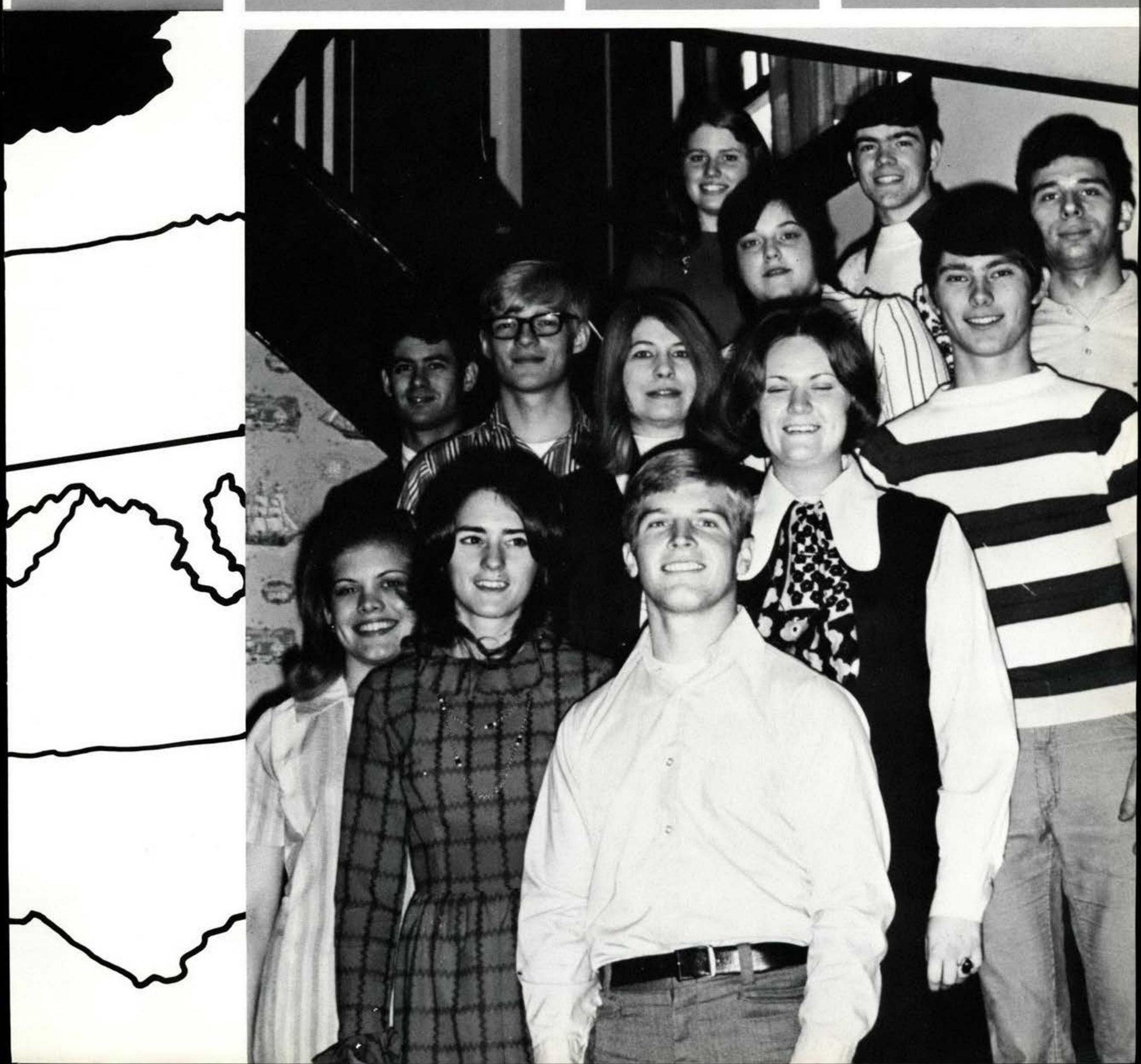


9 o'clock and 10 o'clock
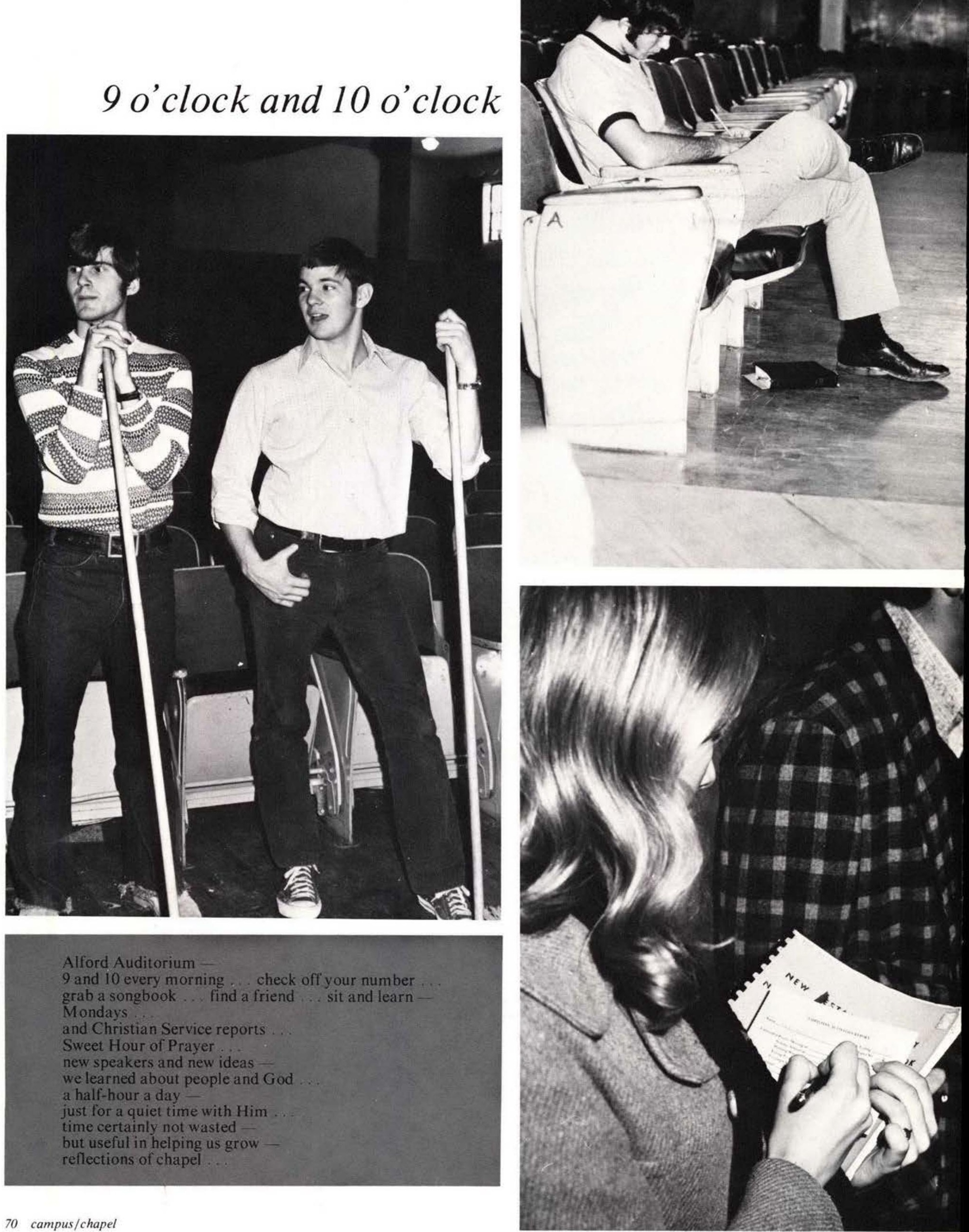

Alford Auditorium -

9 and 10 every morning ... check off your number grab a songbook .... find a friend ... sit and learn

Mondays

and Christian Service reports

Sweet Hour of Prayer

new speakers and new ideas

welearned about people and God

a half-hour a day

just for a quiet time with Him

time certainly not wasted

but useful in helping us grow -

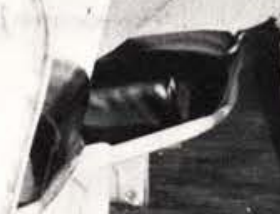



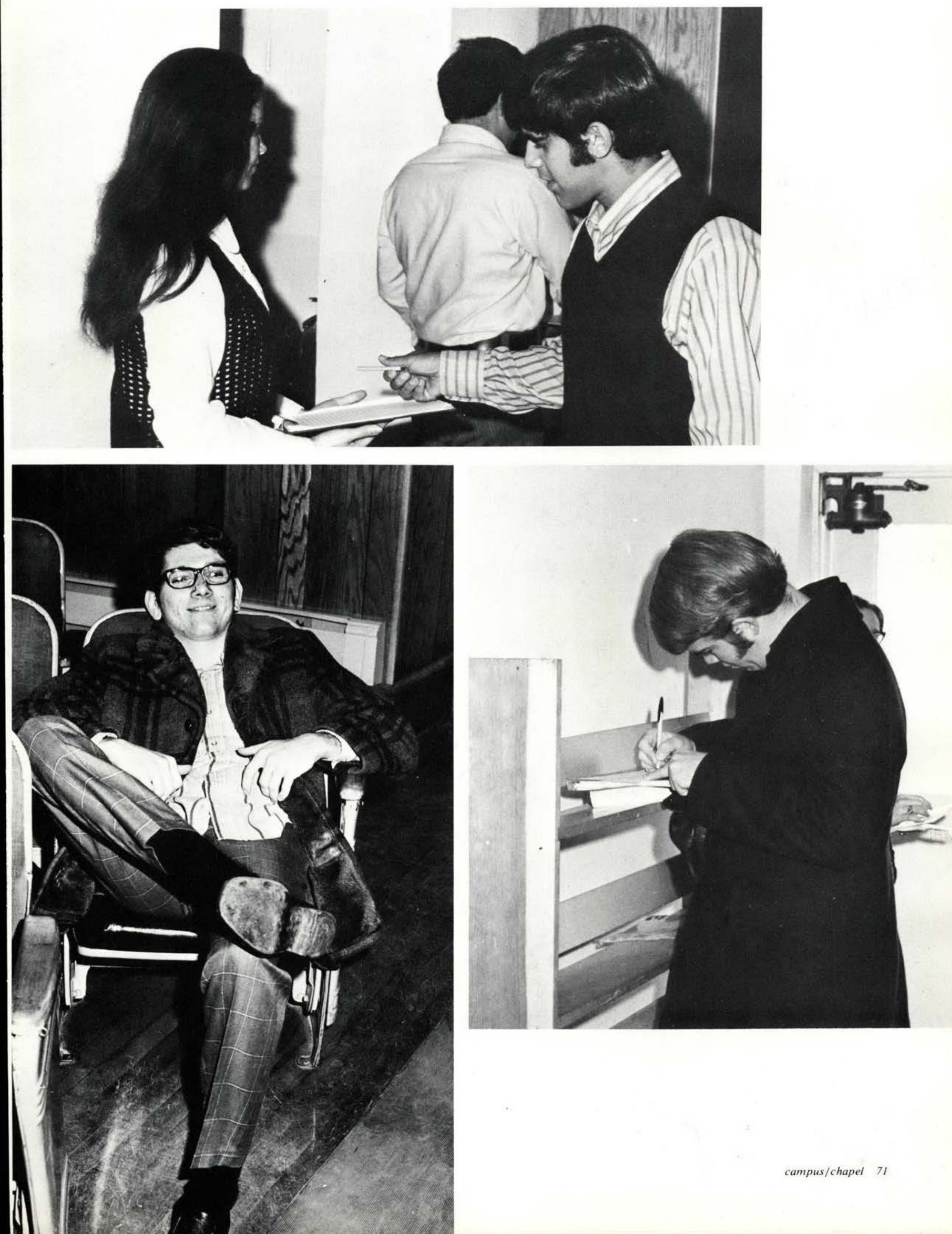
Dr. Charles C. Ryrie

Dallas Theological Seminary

Dr. Clifford Johnson

Academic Dean

Mr. Kenneth St. Clair

Business Mgr

Mr. Lee C. Turner

Director of Development
Mr. Donald Rickard

Dean of Students

Rev. Joseph Stowell

Southgate Baptist Church

Springfield, Ohio

Rev. Donald Sewell

Emmanuel Baptist Church

Toldeo, Ohio

Rev. John Teeters

Emmanuel Baptist Church

Xenia, Ohio

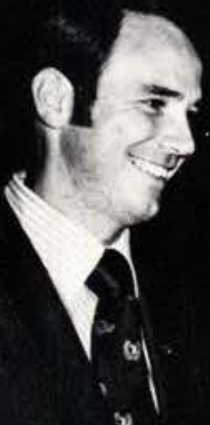

5)

5

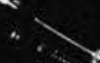

, 1

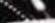
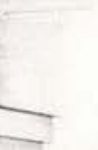

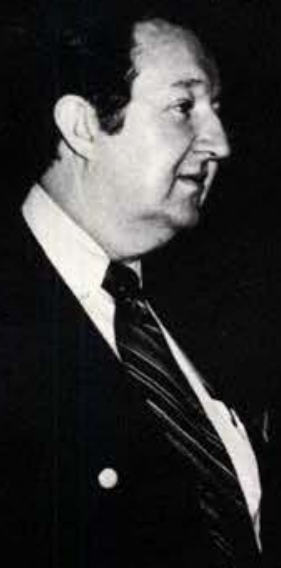

$\theta$

$\checkmark$

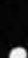
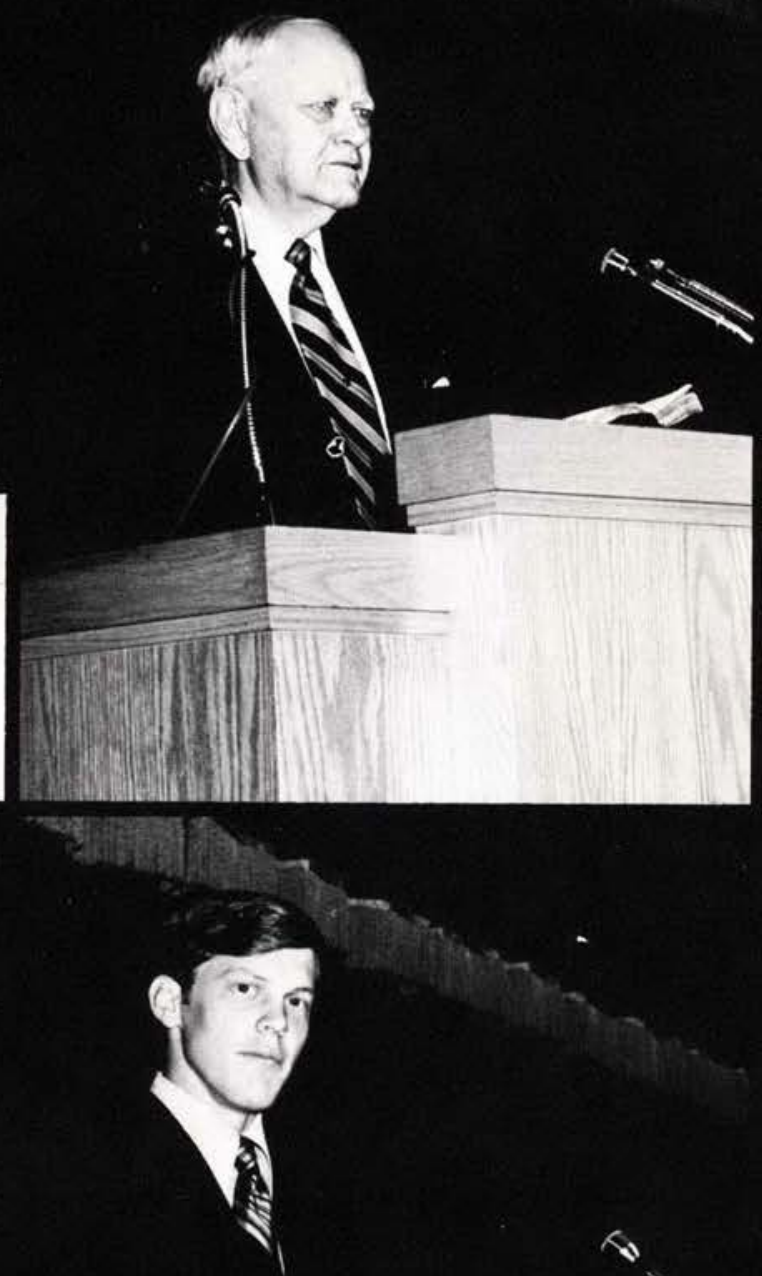

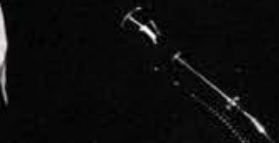

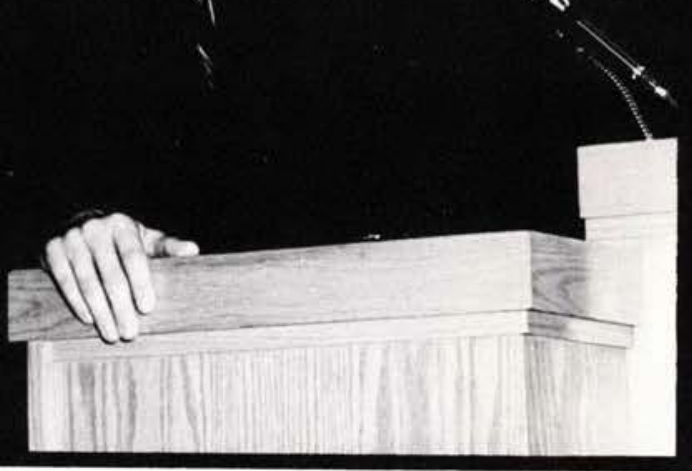

Mr. R. Stanley Tam

States Smelting and Refining Corp. Lima, Ohio

Mr. Owen F. Lower

Bible Christian Union in Europe

Rev. William Carter

New Harmony Baptist Church

Caldwell, Ohio

Rev. Arwyn Reish

Berean Baptist Church

Portage, Michigan
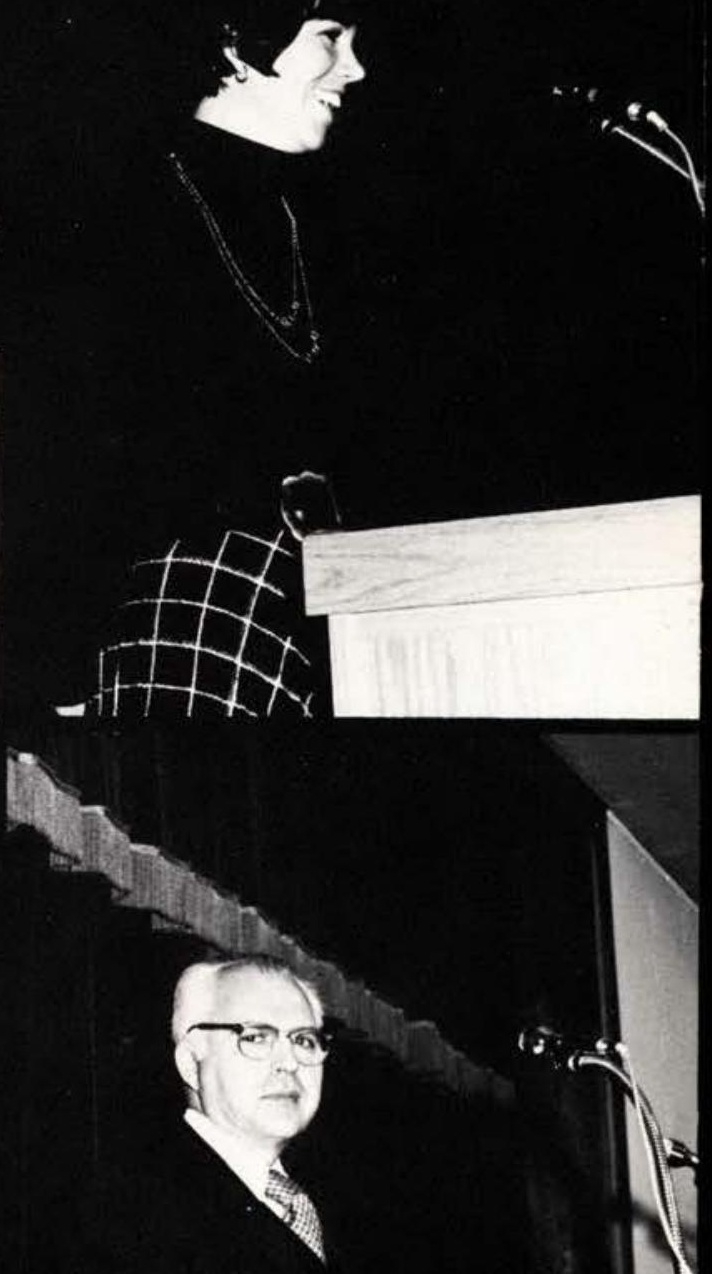

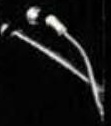

.

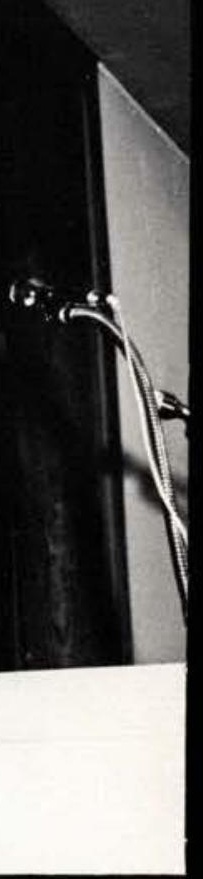

Rev. John Polson

Calvary Baptist Church

Highland, Indiana

Rev. Gerald Fleming

Dayton Baptist Temple

Dayton, Ohio

Rev. Norman Vernon

Napier Parkview Baptist Church

Benton Harbor, Michigan

Evangelist Freddy Gage

Dr. W. Thomas Younger

Immanuel Baptist Church

Fort Wayne, Indiana 
Rev. Nile Fisher

Emmanuel Baptist Church

Dayton, Ohio

Evangelist Dusty Rhodes

Rev. Kenneth Andrus

Blessed Hope Baptist Church

Springfield, Ohio

Rev, Sam Canine

Grace Baptist Church

Lima, Ohio

Rev. Carl R. Stephenson,

County Line Baptist Church

Dayton, Ohio

Rev, Larry Engle

Grace Baptist Church

Toledo, Ohio

Rev. Donald Tyler

Bethesda Baptist Church

Brownsburg, Indiana

Dr. James T. Jeremiah

President

Mr. Donald Moffat

Editor Ohio Independent Baptist
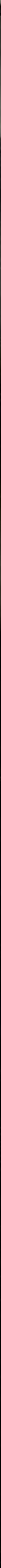

Dr. Mitchell Seidler

Norwood Baptist Church

Cincinnati, Ohio

Chaplain Robert I. Brown

Lebanon Correctional Institute

Lebanon, Ohio

Rev. Richard Durham

President, Baptist Bible Seminary

and Institute, Manilla

Dr. John G. Balyo

Cedar Hill Baptist Church

Cleveland Heights, Ohio
Rev. William Fusco

Baptist Mid-Missions

Dr. Robert T. Ketcham

Chicago, Illinois

Rev. Kenneth Good

North Olmsted Baptist Church

North Olmsted, Ohio

Dr. Allen Monroe

Professor of Social Science 
Mr. James Grier

Associate Professor Philosophy

Rev, King A. Butler

Bible Baptist Church

Kalamazoo, Michigan

Dr. Richard W. Bolander

General Motors Institute

Flint, Michigan

Rev. Marvin Troyer

Glen Park Baptist Church

Gary, Indiana
Mrs. Peggy Bush

Singer

Bellfontaine, Ohio

Rev. James Paige

Bible Baptist Church

Newark, Ohio

Rev. Hermann J Austel, Dean

Los Angeles Baptist Seminary

Newhall, California

Rev. Roy Clark

Bethleham Baptist Church

Cleveland, Ohio
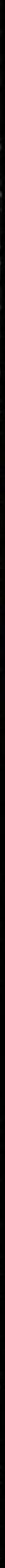

Rev. Harold Amstutz

Assoc. of Baptists for

World Evangelism, Inc.

Cherry Hill, New Jersey

Dr. G. Douglas Young, Pres.

Amer. Inst. of Holy Land Studies

Israel

Western Baptist Bible College Choir

Salem, Oregon

Rev. Lloyd Morris

Riverdale Baptist Church

Flint, Michigan
Rev, Lynn Rogers

Northfield Baptist Church

Northfield, Ohio

Mr. James Frantz

Principal Keifer Jr. H.S

Springfield, Ohio

Dr. John Whitcom

Grace Theological Seminary

Winona Lake, Indiana

Mr. Paul Bubar

Word of Life

Schroon Lake, New York 
Mr. Ward Harris

Missionary from Africa

Dr. G. Beauchamp Vick

Temple Baptist Church

Detroit, Michigan

Akron Baptist Temple

Mr. Rousas John Rushdoony

Akron, Ohio

Christian Philosopher

Rev. Milo Thompson Canago Park, California

Fellowship, New York $\quad$ Rev. David L. Moore

Mr. James Butcher, Attorney

Kokomo, Indiana

Rev. Guy E. King, Gen. Dir.

Rev. David L. Moore

Walnut Ridge Baptist Church

Waterloo, Iowa

Rev. David T. Jeremiah

Blackhawk Baptist Church

Hiawatha Baptist Missions

Fort Wayne, Indiana
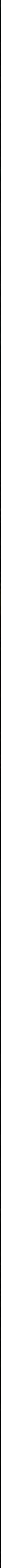

Evangelist Paul Dixon

Cedarville, Ohio

Congressman Clarence J. Brown

7th Ohio District

Rev. Richard Blumenstock

Bible Baptist Church

Huntington, Indian

Mr. Gordon Wimer

Missionary Republic of Chad

Baptist Mid-Missions

Dr. N. A. Wiens

Grand Rapids Baptist Seminary

Grand Rapids, Michigan
Rev Walter L. Banks

Bible Baptist Church

Cleveland, Ohio

Mr. James P. MacLean III

Archer, Greiner, Hunter \& Read

Camden, New Jersey

Dr. Monroe Parker

Evangelist

Decatur, Alabama

Mr. Dave Fidler

Missionary Memorial Christian

Hospital, East Pakistan

Rev. Robert Shelton

First Baptist Church

Pontiac, Michigan 


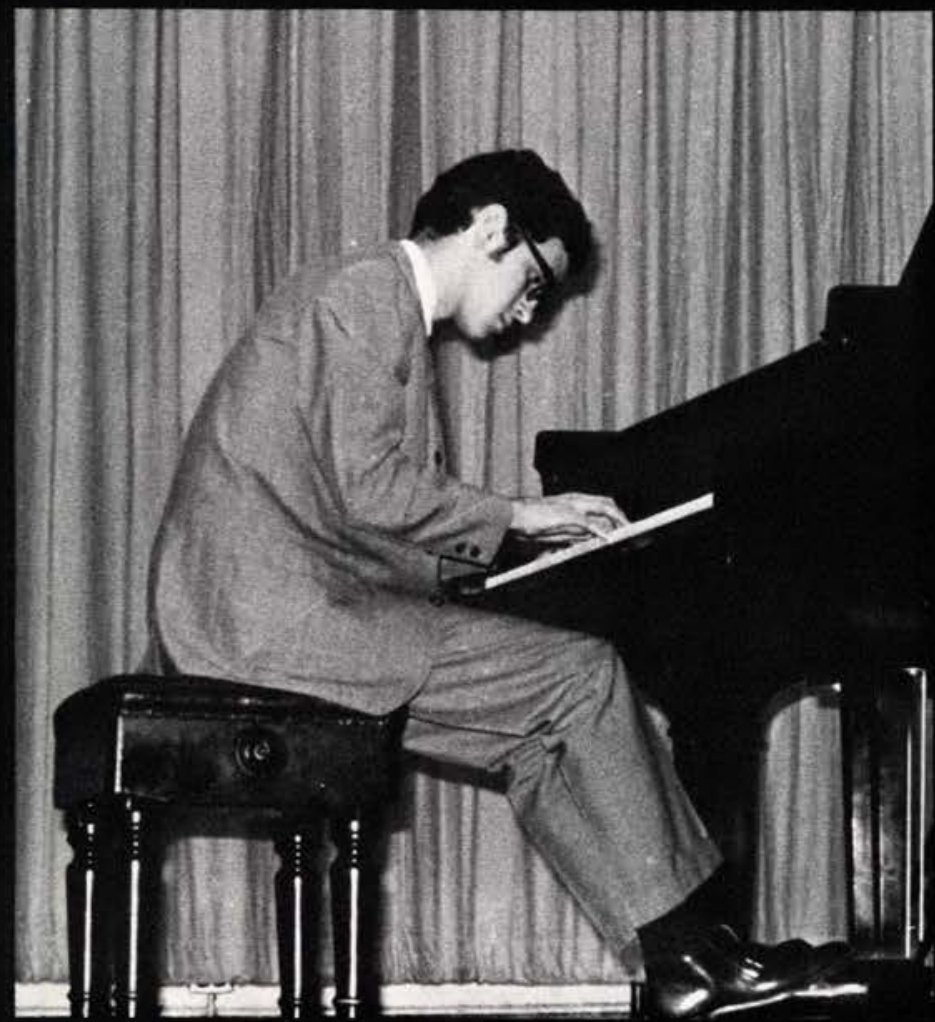

How's it going, Jim?

You sure had us worried there for a while. Everybody was having such a good time and suddenly .... you disappeared. Why did He let you do it? Didn't He know how much talent you had? Didn't He know that with a little maturing you could have given forty or fifty years of marvelous service as a Christian musician? You'll never be a college graduate, a husband, a father, a professional musician or a missionary. Last Saturday was wrong! It should have been one of the rest of us who's had a little more chance at life! Somebody goofed! What on earth is your 21 year old body doing in a jungle grave? It's downright cruel of Him, Jim!

Wait a minute, friends!

Just hang loose and listen to me for a minute! There's no sense in getting all up-tight about something you don't understand. I don't even know where to begin. It's all so great here! You know how great I thought Quito was! Well, don't get your feelings hurt friends, but Quito is nowhere! Wait till you get a load of the organ. It's absolutely out of sight! Five manuals and a thousand feet of solid gold pipes! The sound is glorious ... I can't begin to describe it. You feel it as much as you hear it. I was going to be humble and not tell you who got the job of organist - but I can't resist. You don't believe me? Well, it was quite a rough audition. Bach and Handel were both on the committee, but I absolutely wowed them. Just imagine, unlimited practice time on an organ like this.

One more thing ... you were worried about fulfillment! Well, you can stop any time. We've been in rehersal ever since I got here for a wedding to end all weddings. Full orchestra, chorus, and of course, organ, in perfect harmony with perfect balance. There aren't any spectators here - for everybody in the wedding party in one way or another.

I guess the greatest thing that's happened since getting here has been my chance to meet the Groom. You can't imagine all the glory and all the attendants waiting on Him in the throne room! When I stepped in. everybody was singing and bowing. and every eye was directed towards the Groom on His throne. That was overwhelming enough in itself. but I couldn't believe it when He stood up, walked slowly through all those millions of people, and walked straight up to me at the back of the room. He shook my hand, just as if I were a long lost friend, and said, "You've done a good and faithful job. Welcome home, my son."

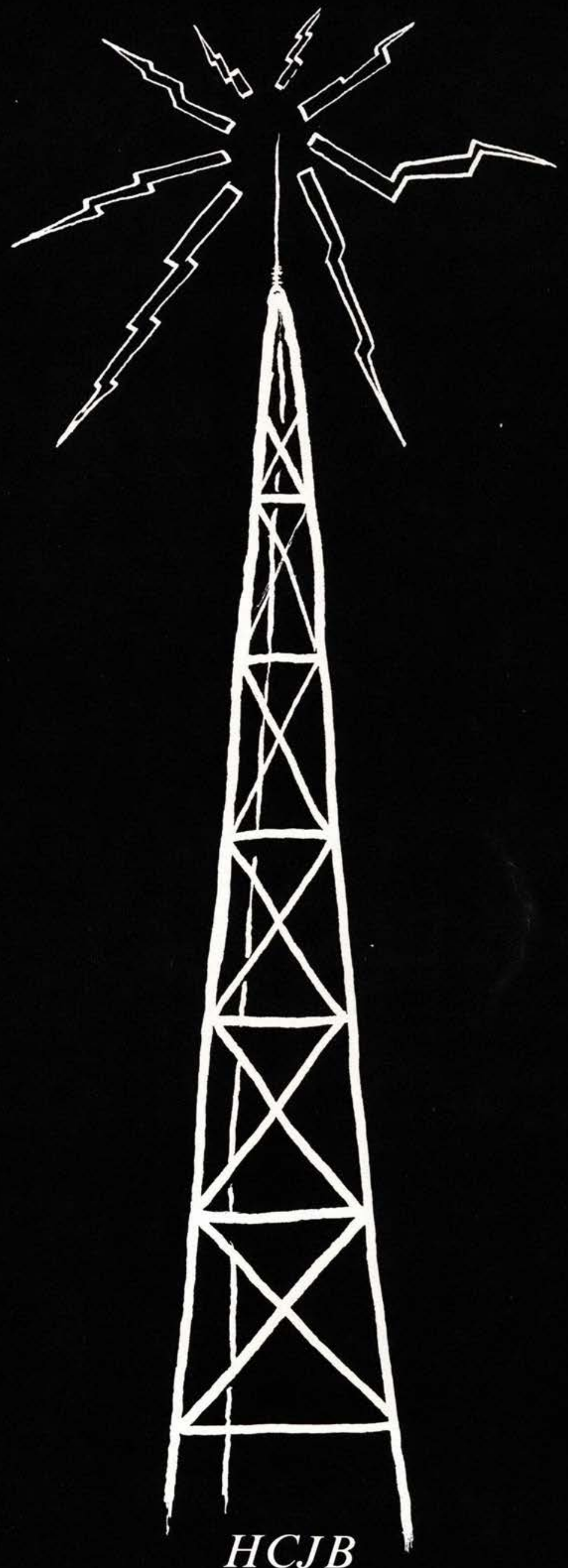




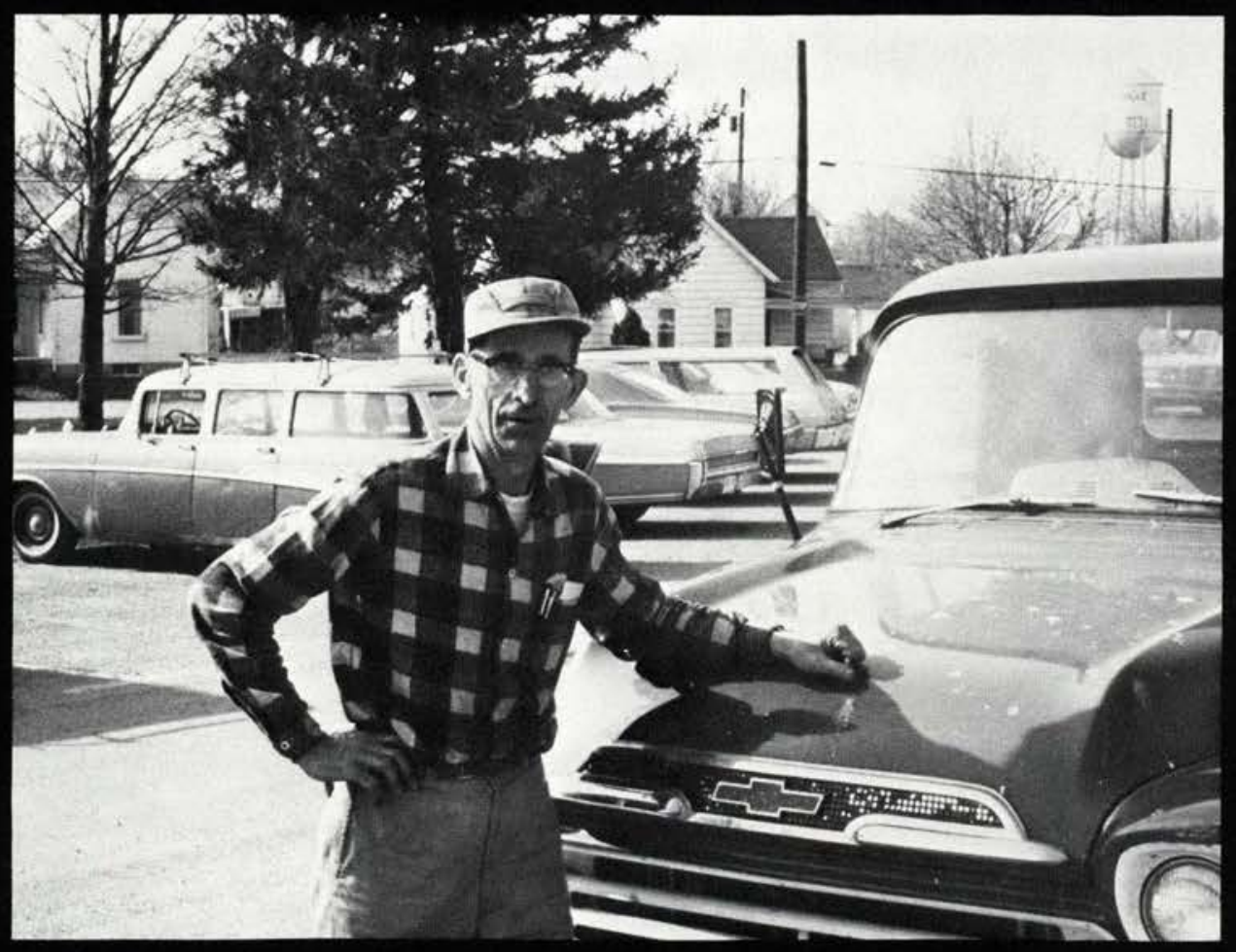

"Faithful in that which is least faithful also in much

A man with a talent from God

to love little things:

antiques, flowers, a small school.

his humor

That was "Pop":

faithful in the tasks

the Lord gave him

a hard worker,

a man of unusual determination,

a mechanic, carpenter, plumber

and electrician all-in-one

That was "Pop!"

Known as school maintainance man.

Campus friend, devoted husband,

more

Pop was a faithful man of God

in his church

head usher at Grace Baptist.

a man who strove to do all

"decently and in order."

An individualist.

one who got things done,

one concerned to work

the school's physical plant,

or donate hours of overtime.

to open a building in early morning hours,

to relight a furnace,

to repair a motor

That was "Pop"

A man who was always a tease,

always in a hurry,

said to have

a "Crusty" exterior but

a "soft-hearted" interior.

A Resident Advisor

at Harriman Hall

One who accepted a

challenge and loved it

That was "Pop".

greatly missed,

but happily present

with the Lord!

"Thou hast been faithful

over a few things,

I will make thee ruler

over many things 


\section{A Tribute To \\ JoAnne Buschmann}
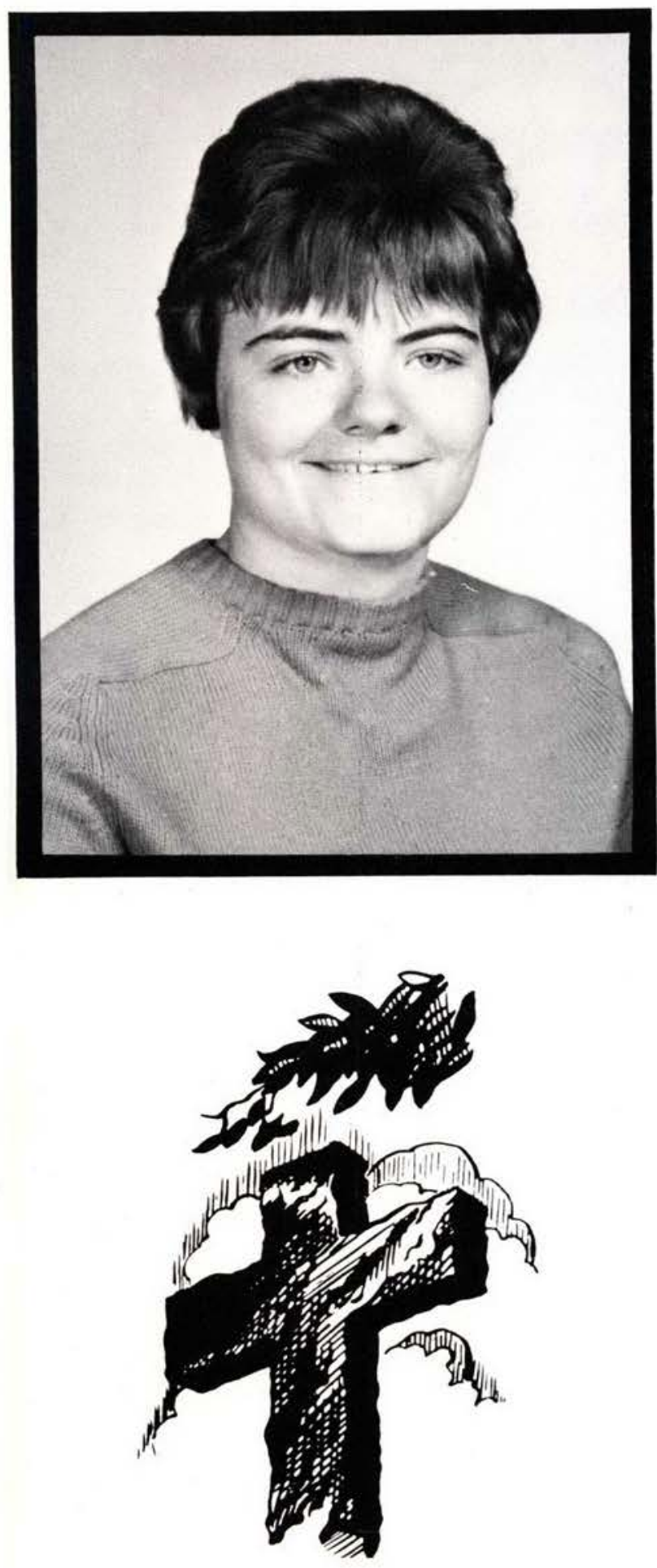

JoAnn Buschmann ...

lived with us for 3 years preparing herself to serve the

Lord in Germany ...

she stood for what she thought was right,

and helped anyone she could ...

she was a real friend

who stuck close by when

things got rough

and laid all problems at the feet of Christ

those who knew her well -

also knew her special Friend

and shared many burdens with Him and with Jo . .

her desire for life can be found in an old hymn that says -

"Let us labor for the Master from the dawn till setting sun,

Let us talk of all His wondrous love and care;

Then when all of life is over, and our work on earth is done,

And the roll is called up yonder,

I'll be there ..."

and Jowould wish to us all -

"When I must leave you for a little while,

Please do not grieve and shed wild tears

But start out bravely with a gallant smile;

Fill each waking hour in useful ways,

Reach out your hand in comfort and in cheer

And I in turn will comfort you and hold you near;

And never, never be afraid to die,

For I am waiting for you in the sky!' 


\section{David Price}

quiet and unboasting

he walked with us here .

never showing discouragement -

always showing Christ ..

constantly seeking to share his Savior,

his "Shepherd of Love",

with anyone who would listen

concerned that he knew God's will for his life

applying Philippians 3:14 to himself a pledge he and his parents had made

long ago .

saying to his Shepherd -

"You sought and found me, -

Placed around me -

Strong arms that carried me home,

No foe can harm me or alarm me -

Never again will I roam

Shepherd of love,

Savior and Lord and Guide,

Shepherd of love,

Forever I'll stay by Your side ...."

we cannot comprehend God's ways -

but Isaiah $57: 1-2$ says

"The good men perish; the godly die before their time and no one seems to care or wonder why. No one seems to realize that God is taking them away from evil days ahead. For the godly who die shall rest in peace."

There are no "accidents" in God's purposes; the STOPS of a good man are ordered as well as his STEPS.

\section{This page given in \\ memory to}

\section{J. David Price, Jr.}
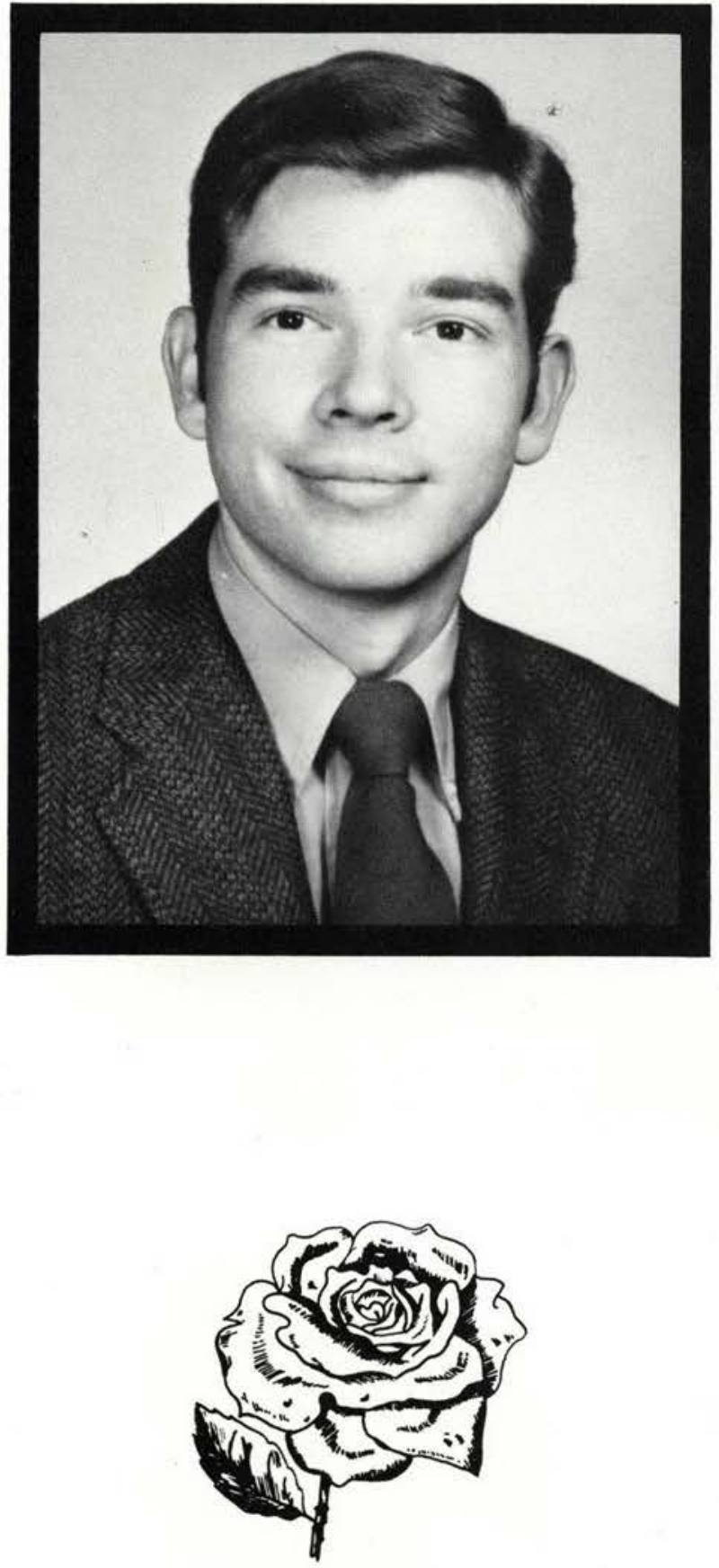


\section{Sword bearers - Summer tour}
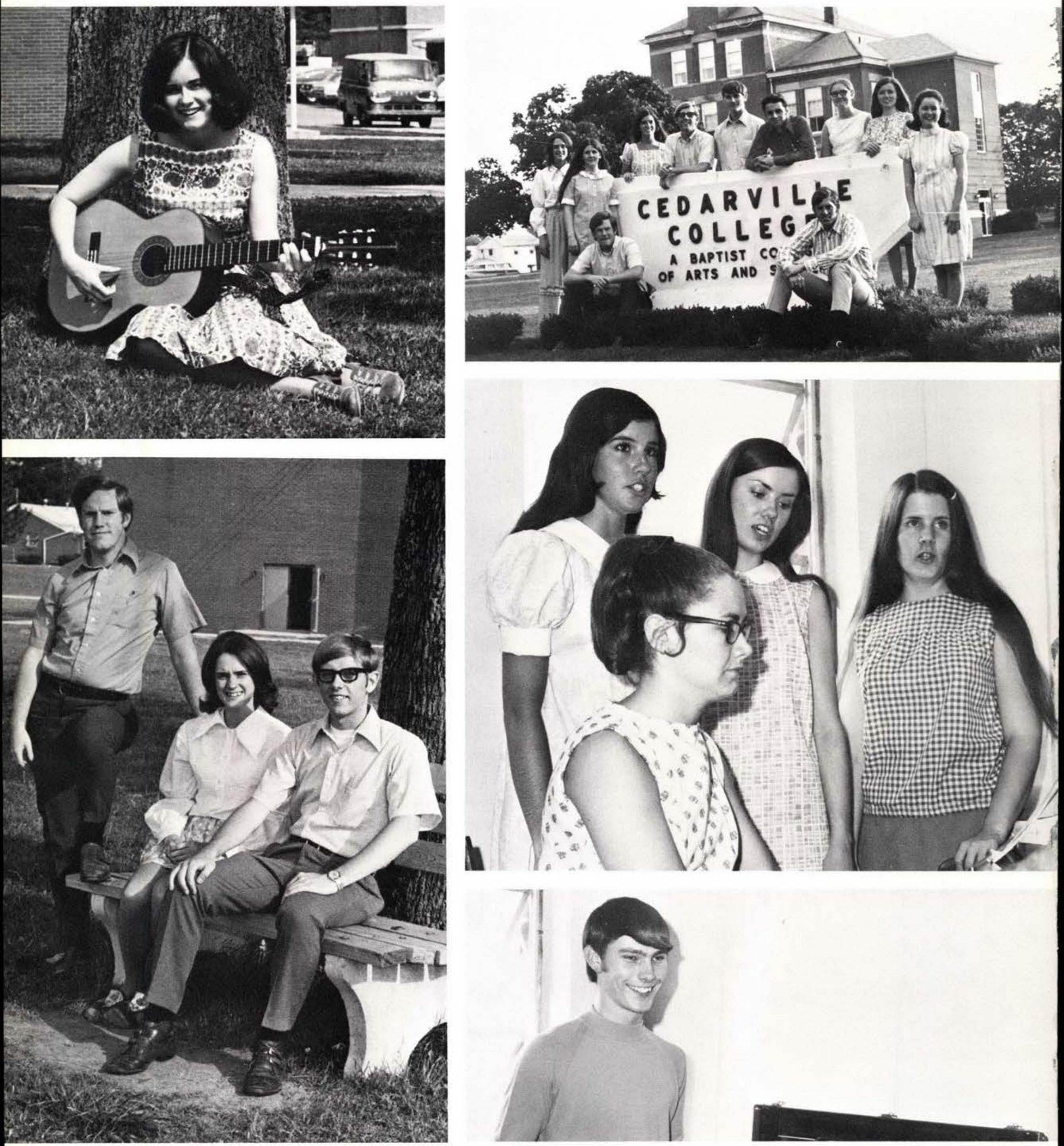

COLLEGS

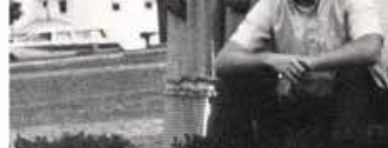

a Baptist CO S OF ARTS AND SIs

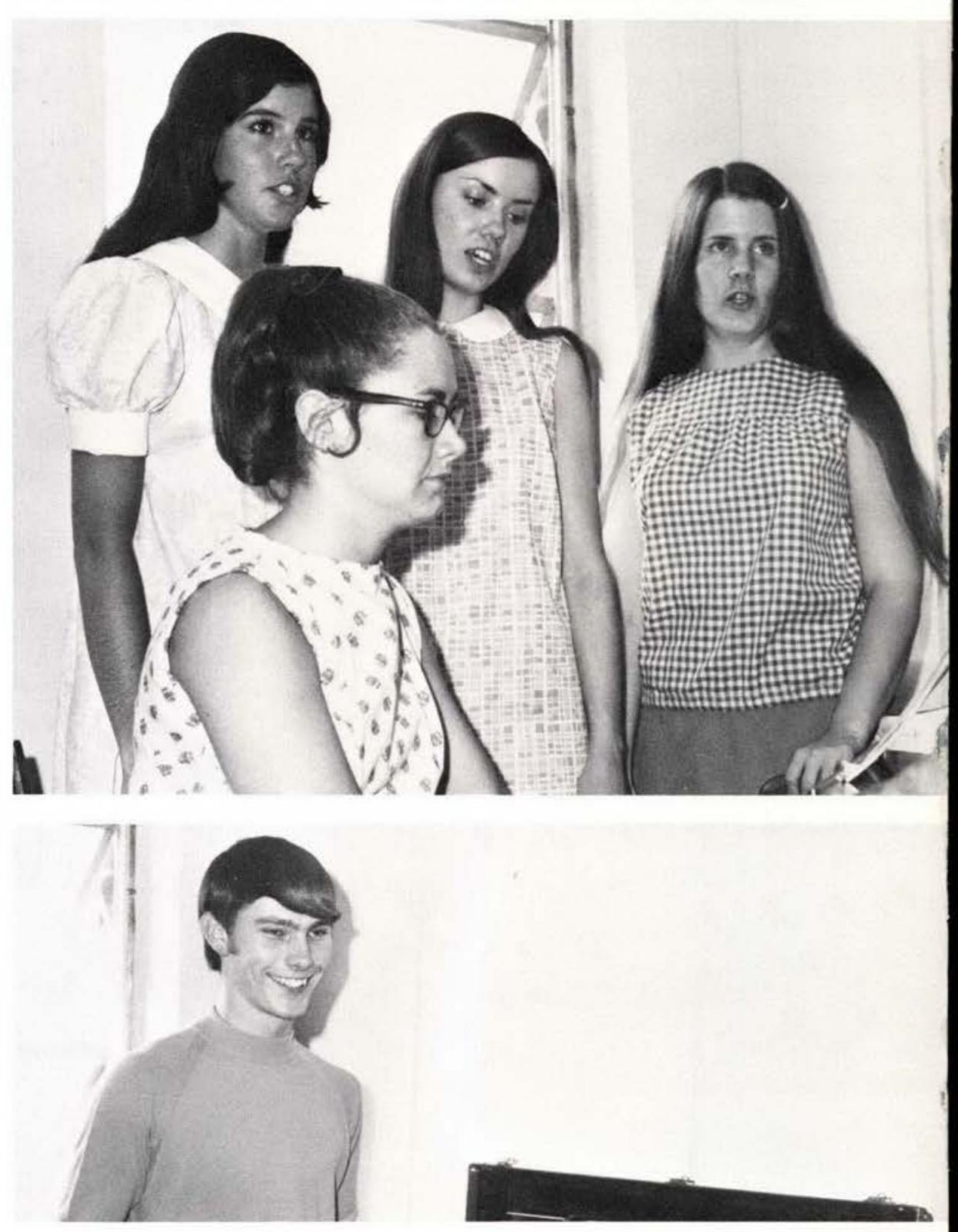



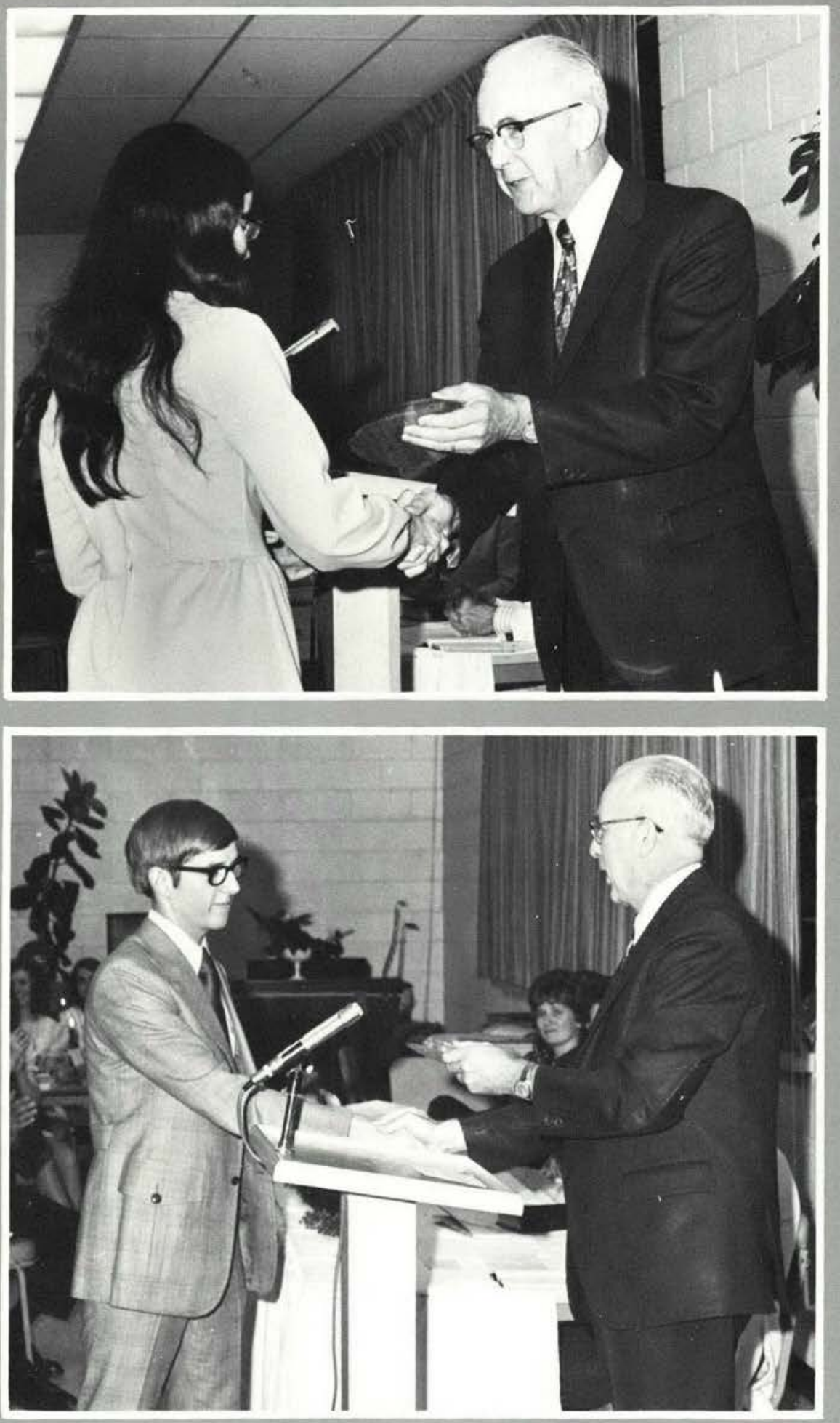

Christian

Service

Banquet

Two were given tangible rewards for work done for Him ... their real dues are yet to come - for they shall receive crowns when He calls us home .... that is a real reward ... 


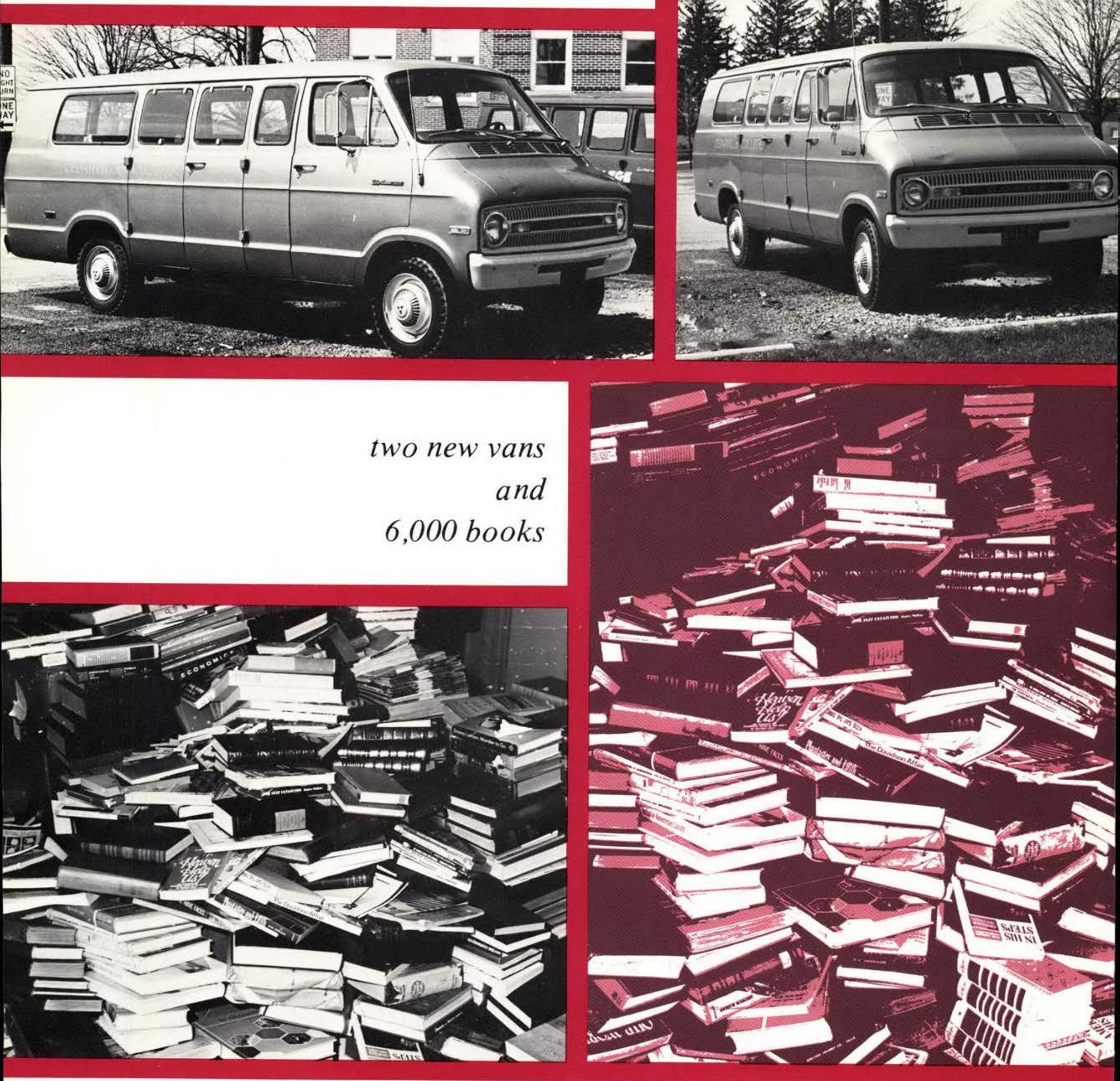

two goals set by the student body and both were achieved - with lots of effort and prayer - for we seek to honor Christ 

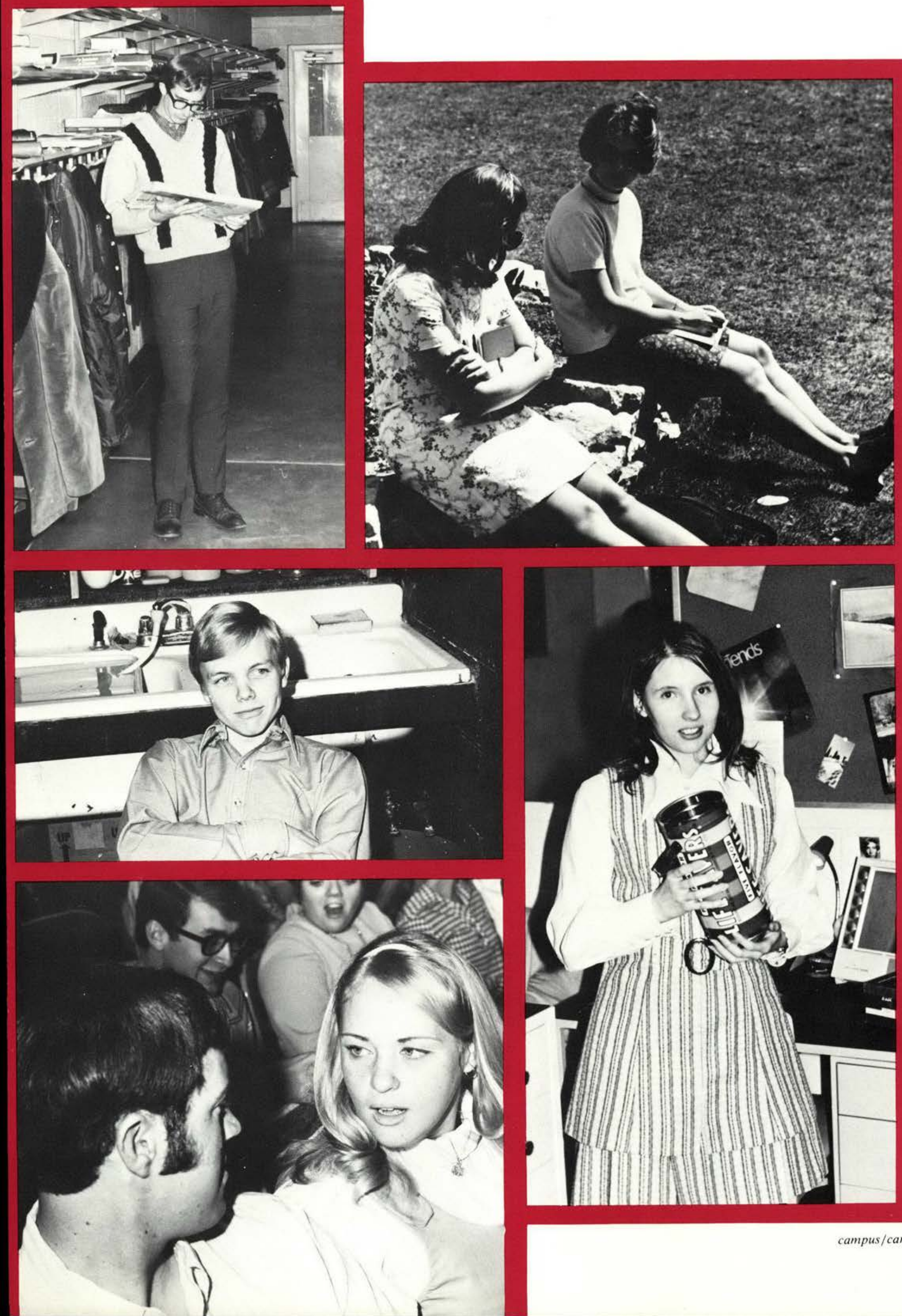

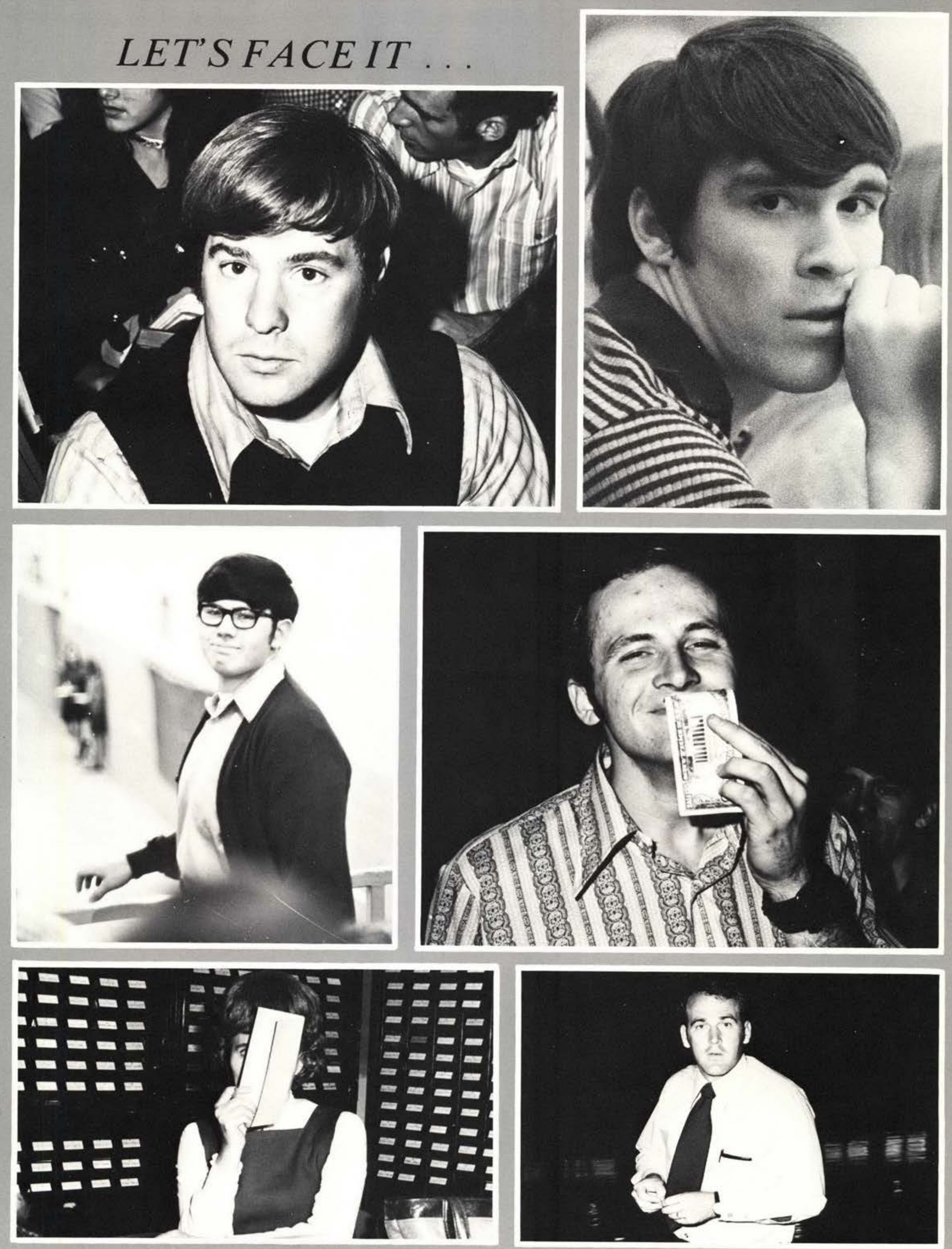

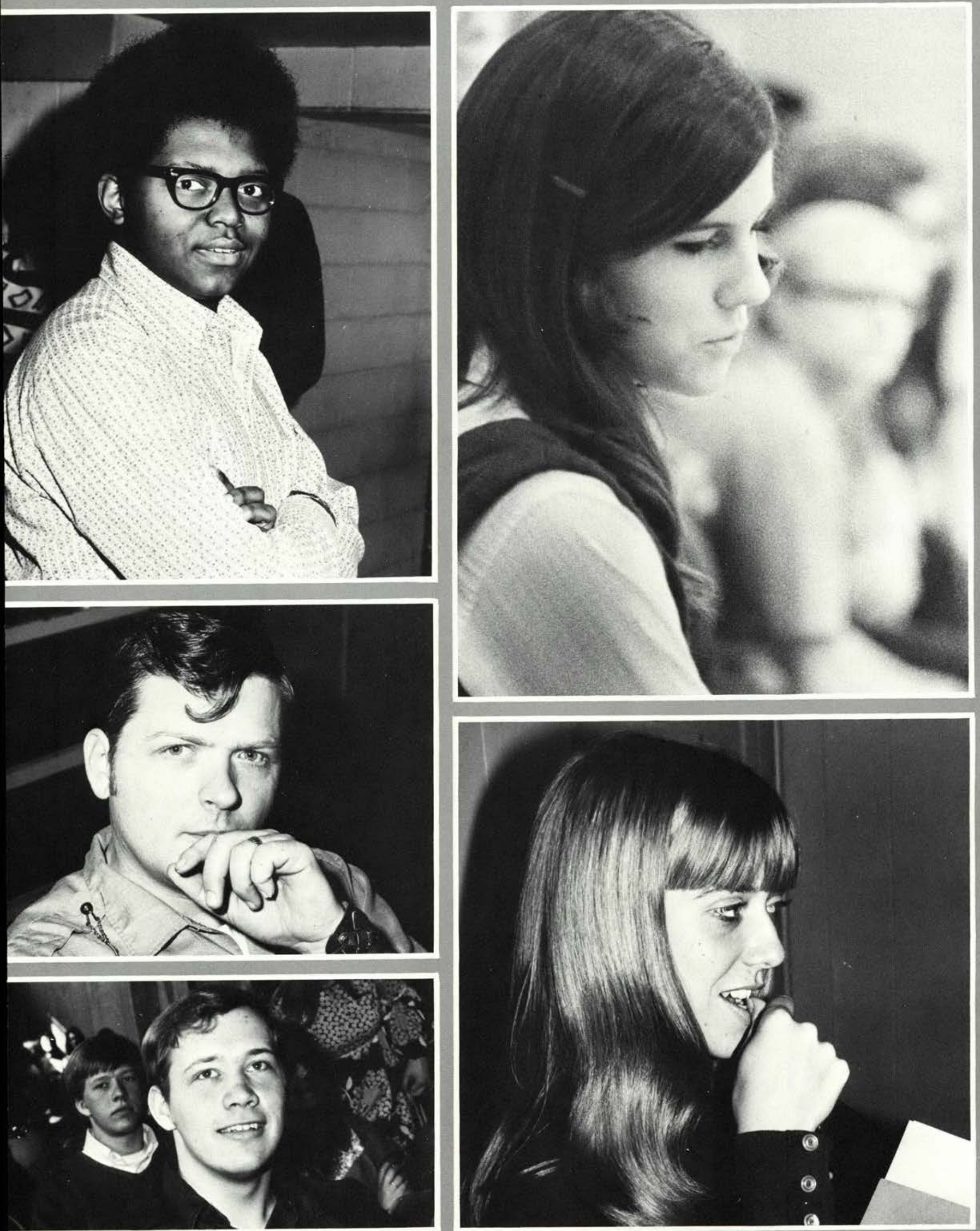
An old science building shell,

A remodeled science building,

A new science center.

During Homecoming

A ground-breaking ceremony

the embarkment and expansion -

of a promising field of study.

We have the old,

and we have the new,

And God is working in both
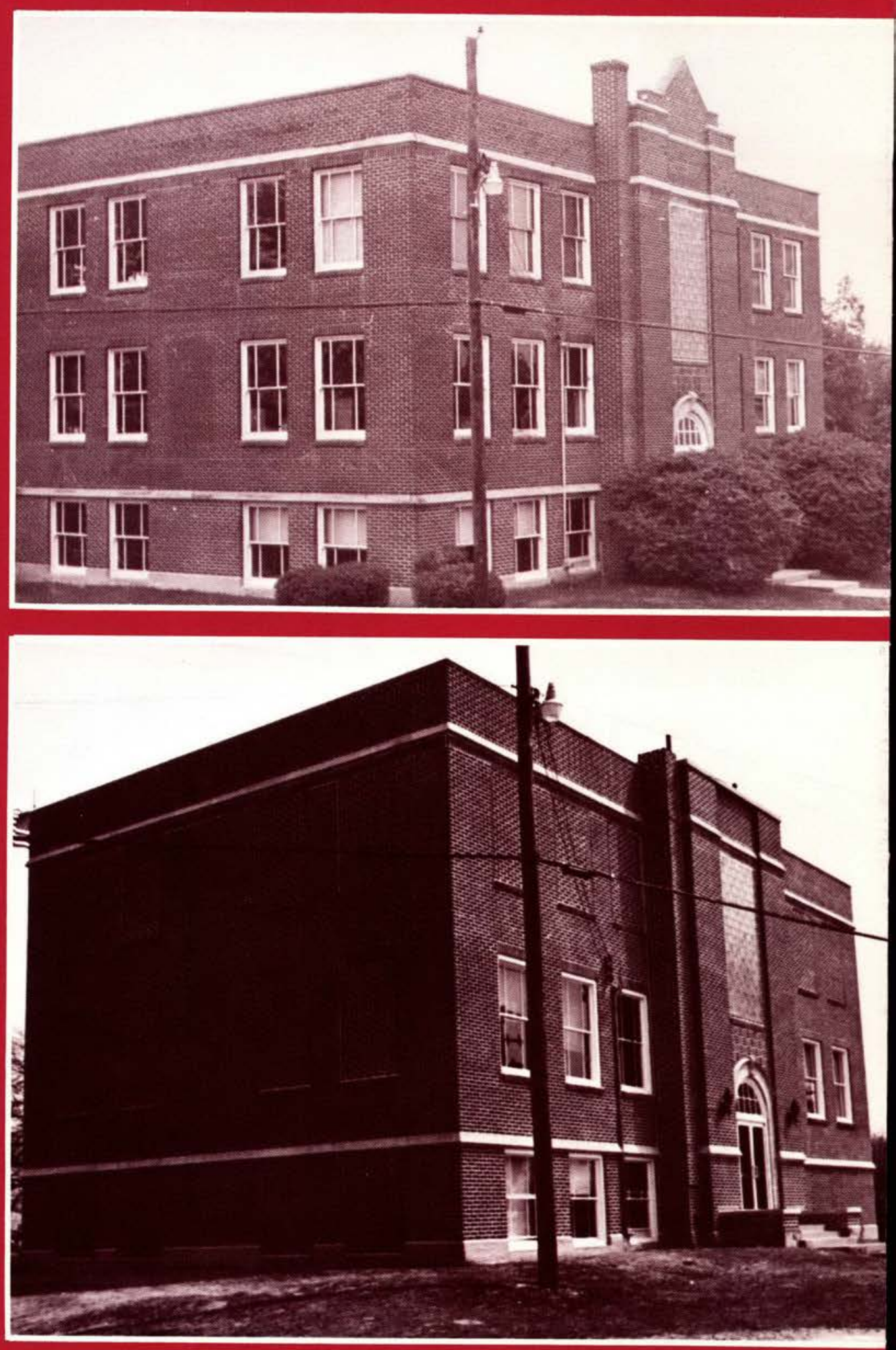

the first of the Three to Grow On ... 

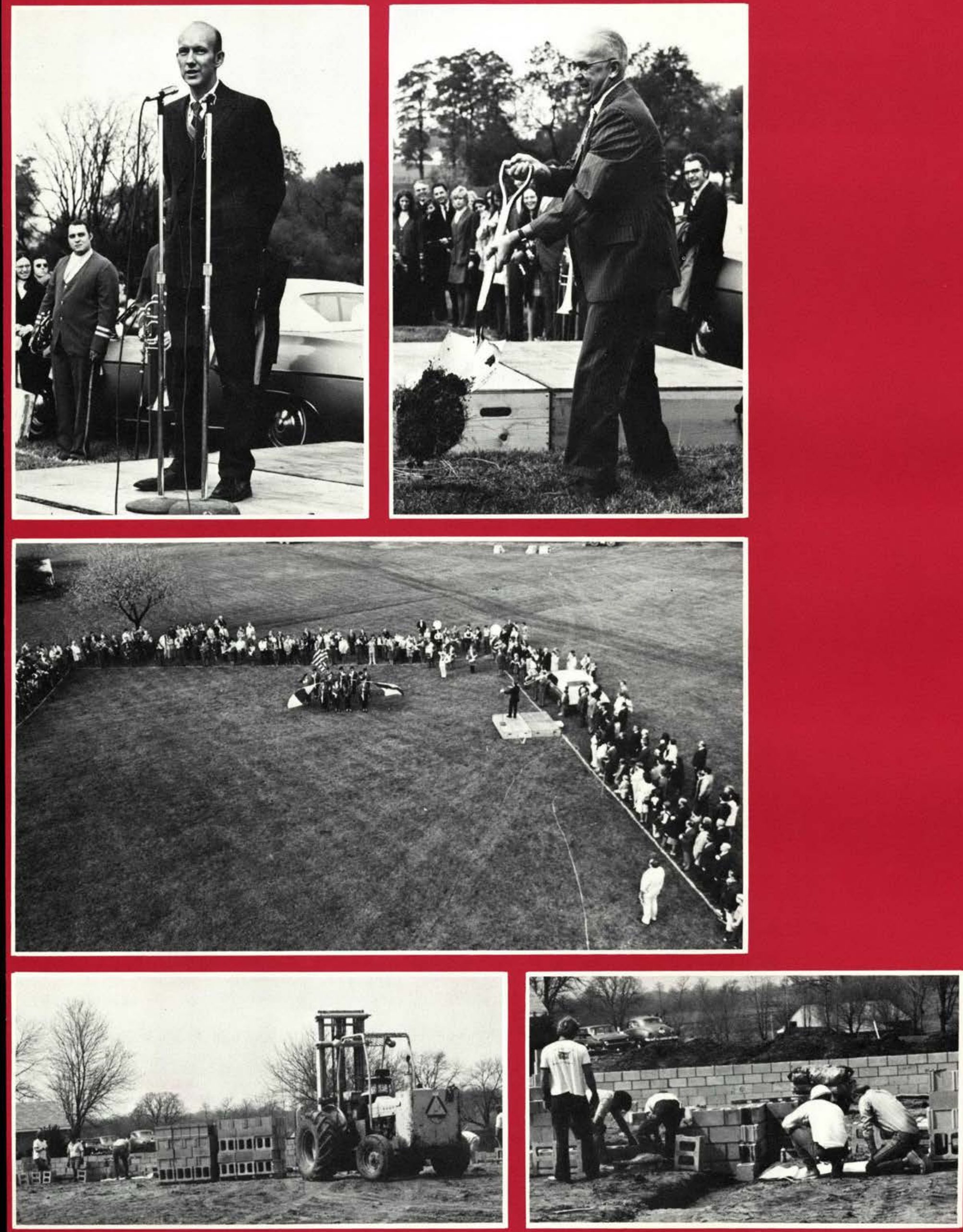


\section{Grand Feast of Cedarshire}
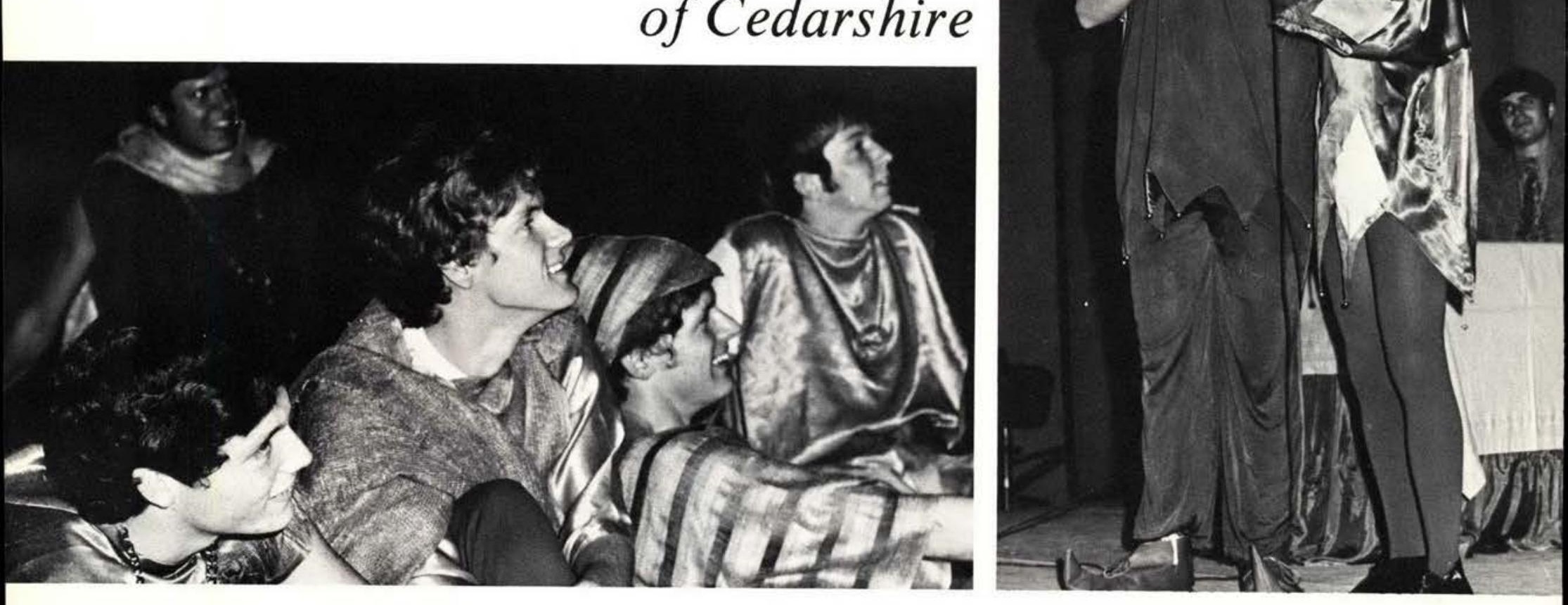

the King's mead hall

Queen Miriam

Large Jonathan and Little Lawrence

vying for the queen's favor -

traveling troupes,

minstrels,

skits -

Love Medevial Style

a great feast,

a funny program,

a fun evening in the years of castles, knights and dragons the Grand Feast of Cedarshire compliments of the damsels of Gamma Chi

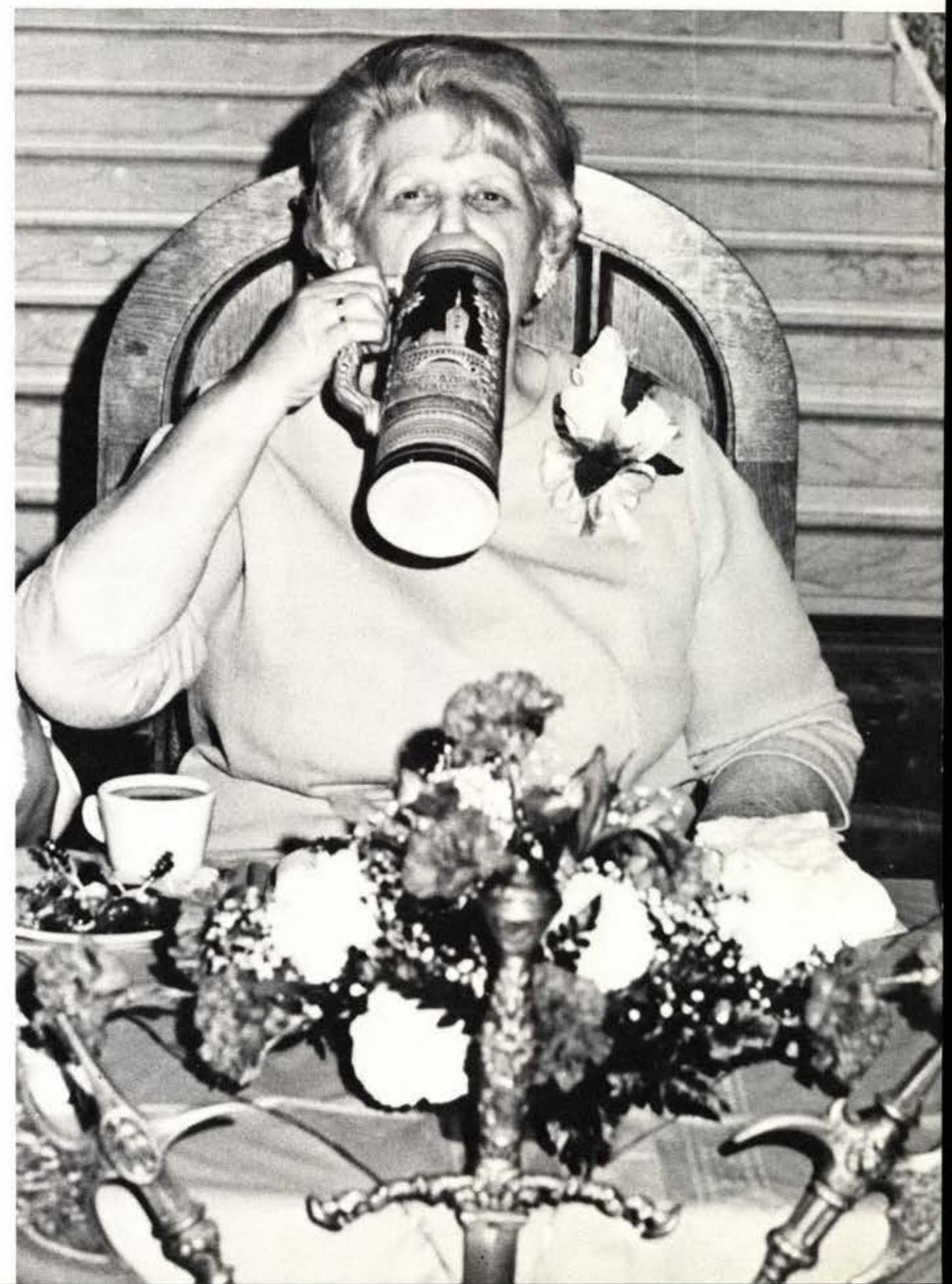




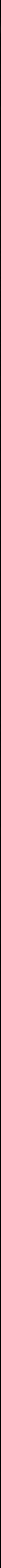





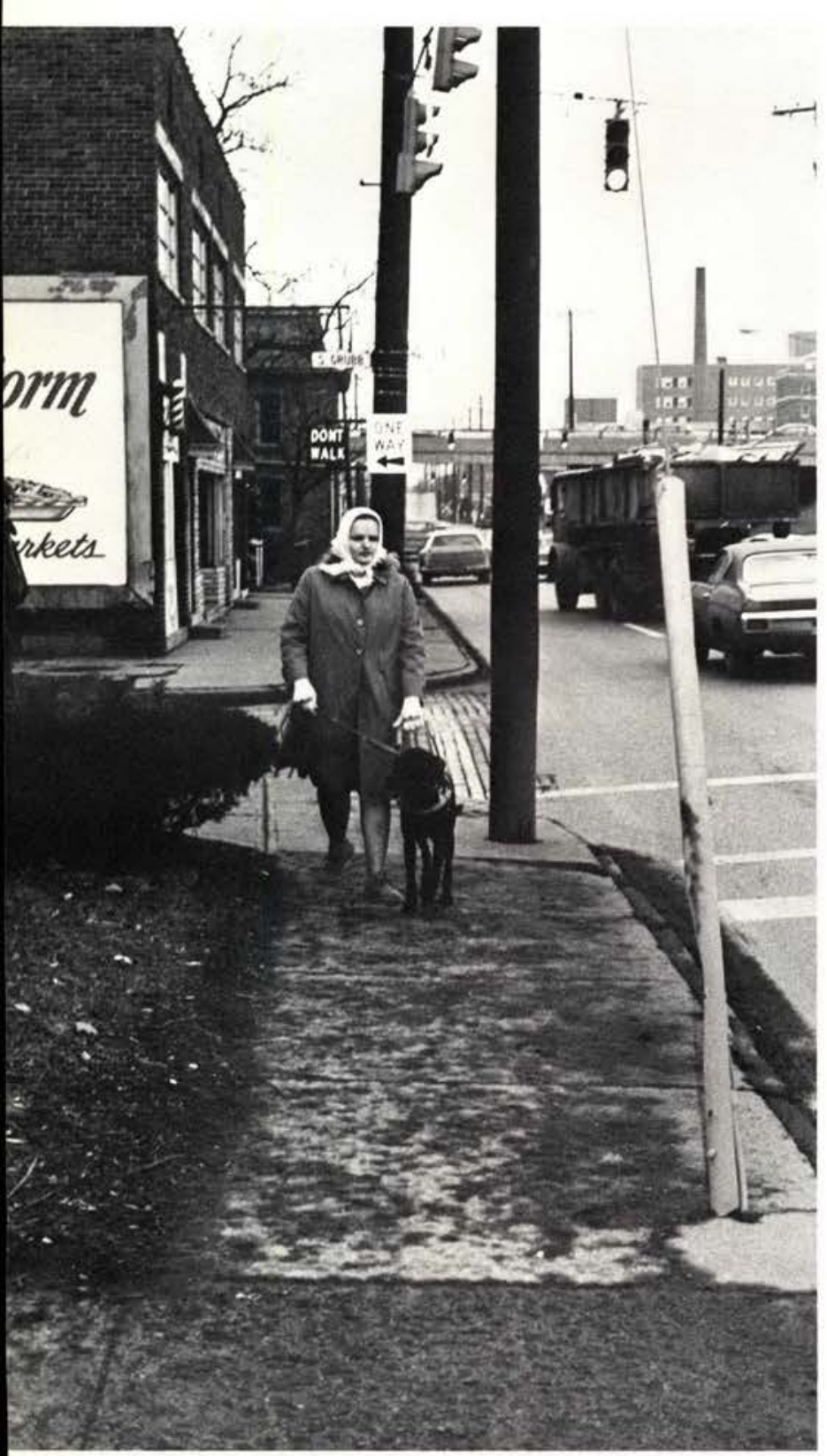

CAMPUS ...
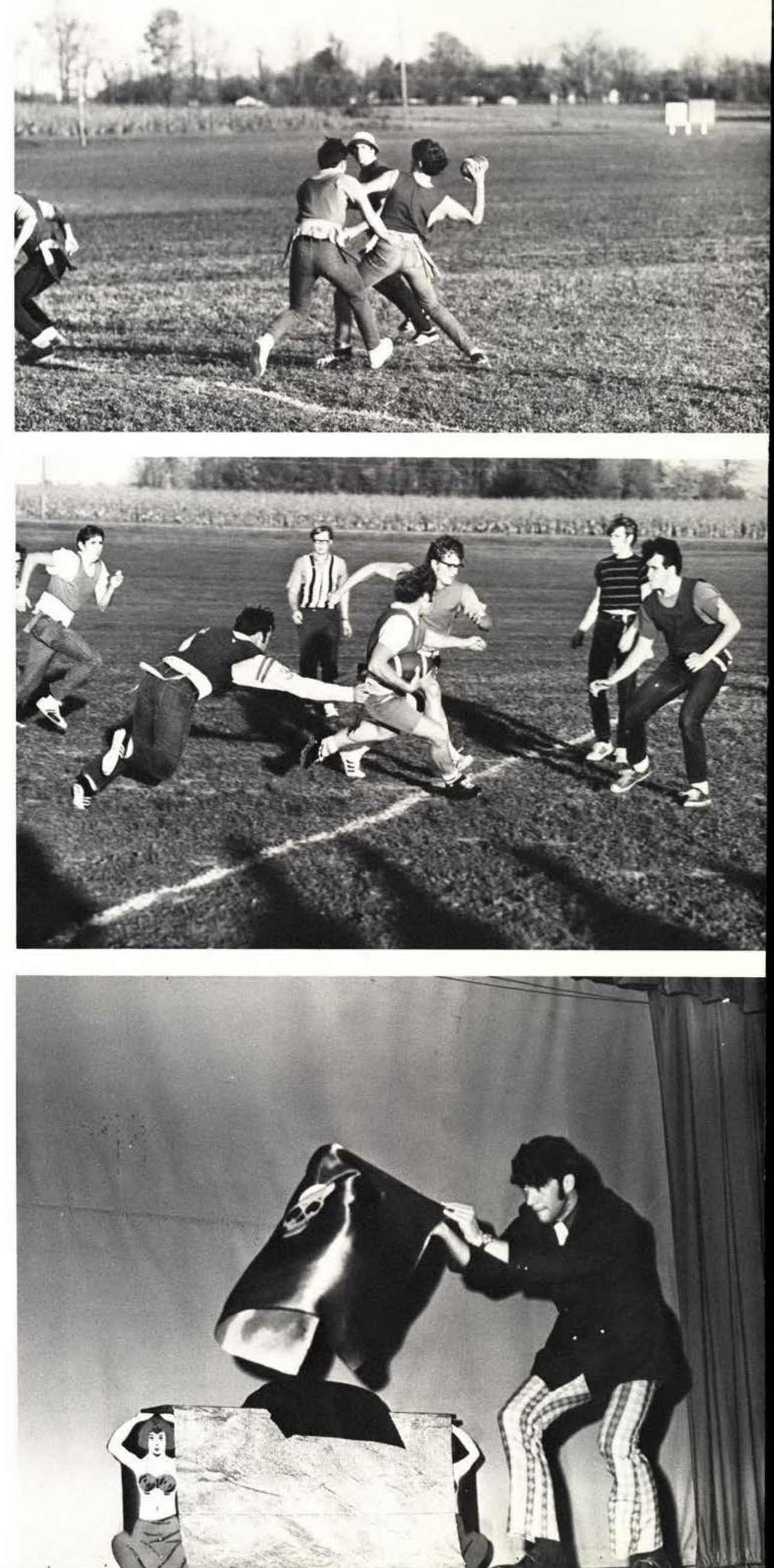
as you have prepared - produce

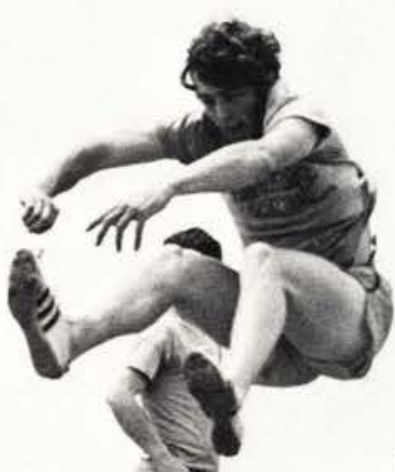

114
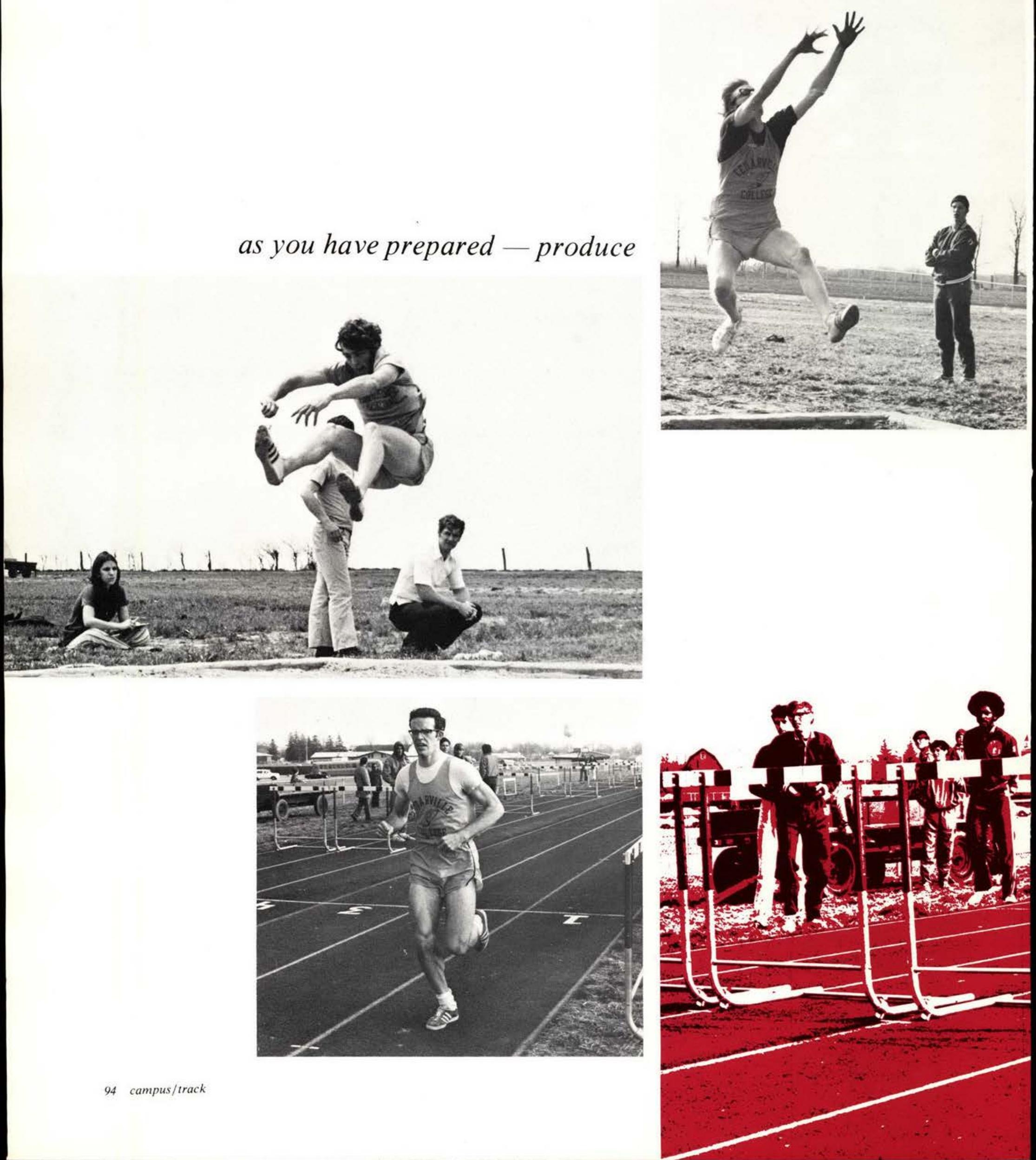

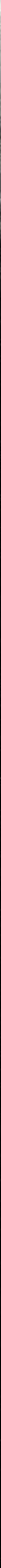

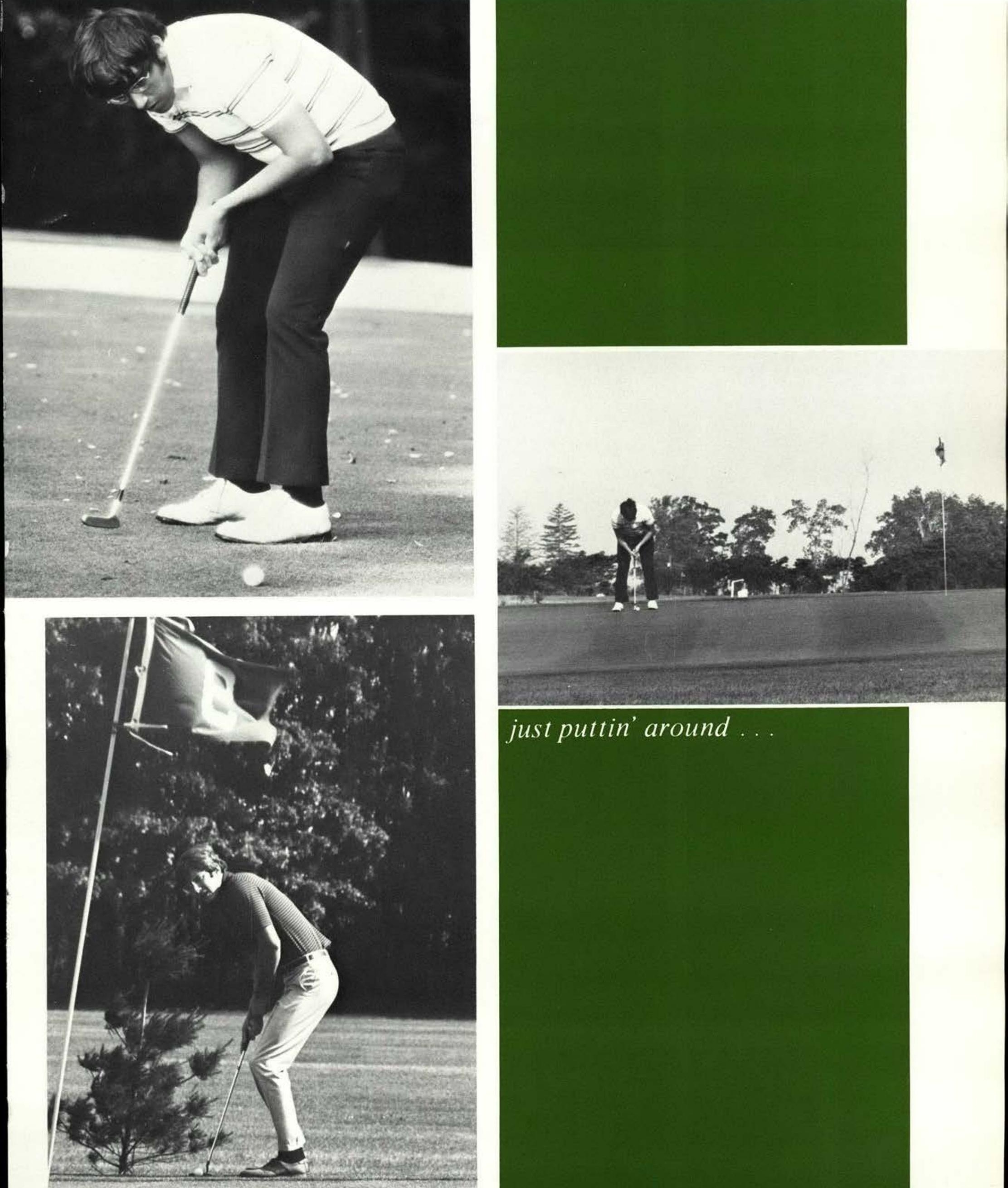

just puttin' around . . . 

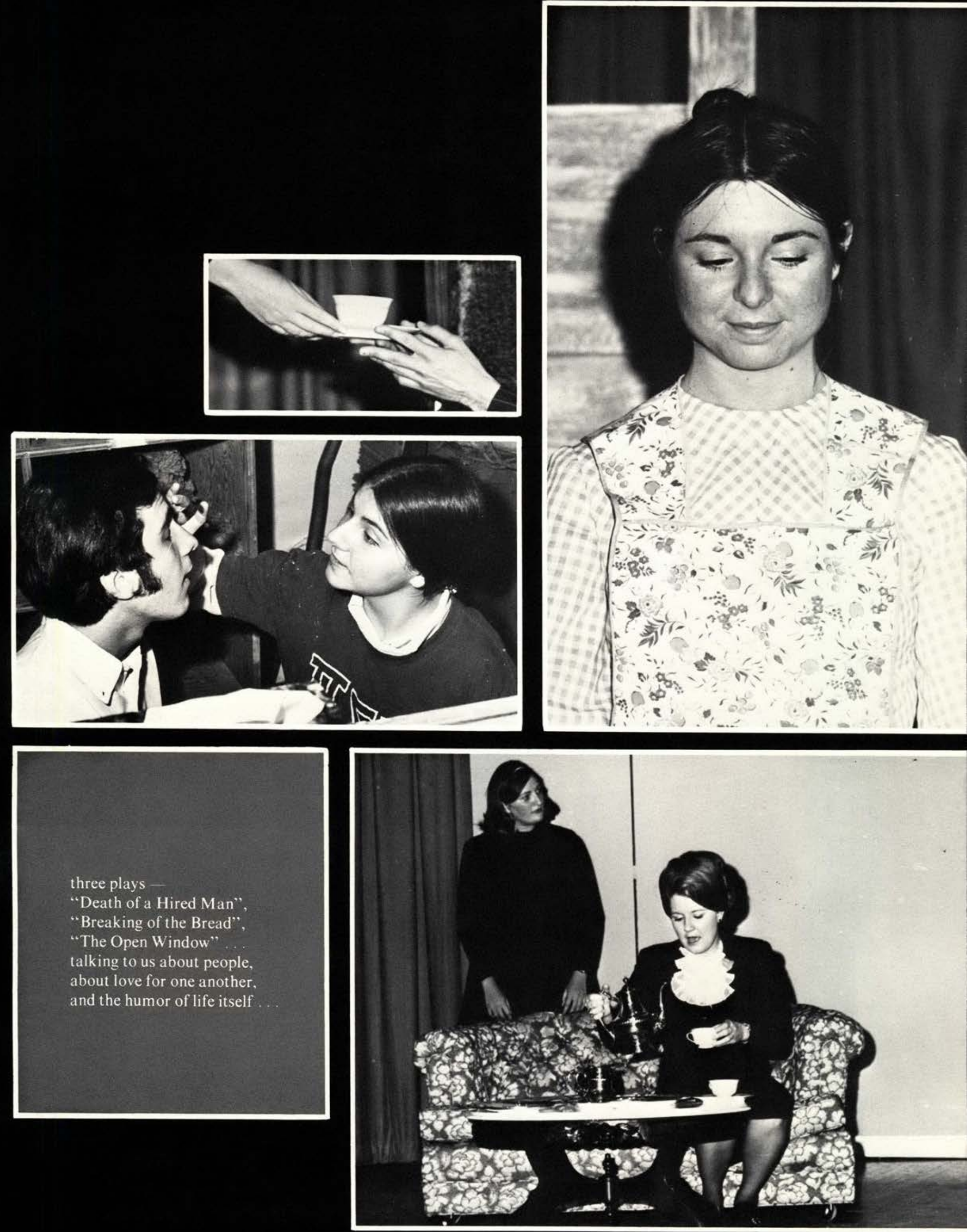


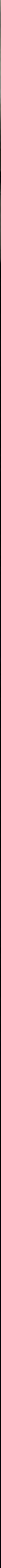

who says college isn't fun ... 
Cheat River Canyon

Cold Water

Rocks

Hydraulics

Lost Paddlers

Found Paddles

"Bail out everybody!"

Rapids

Whitecaps

Bruises

Rubber Rafts -

full of water,

Minus passengers,

Sometimes capsized

A long trip

Blistered hands

And another horrible night

next to Mother Nature,

But 33 people will never forget
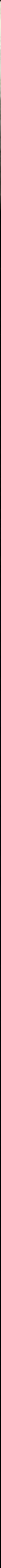

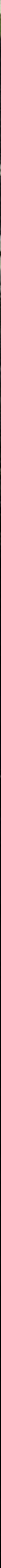

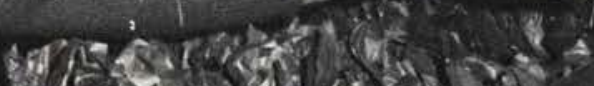

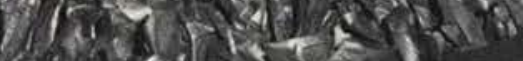



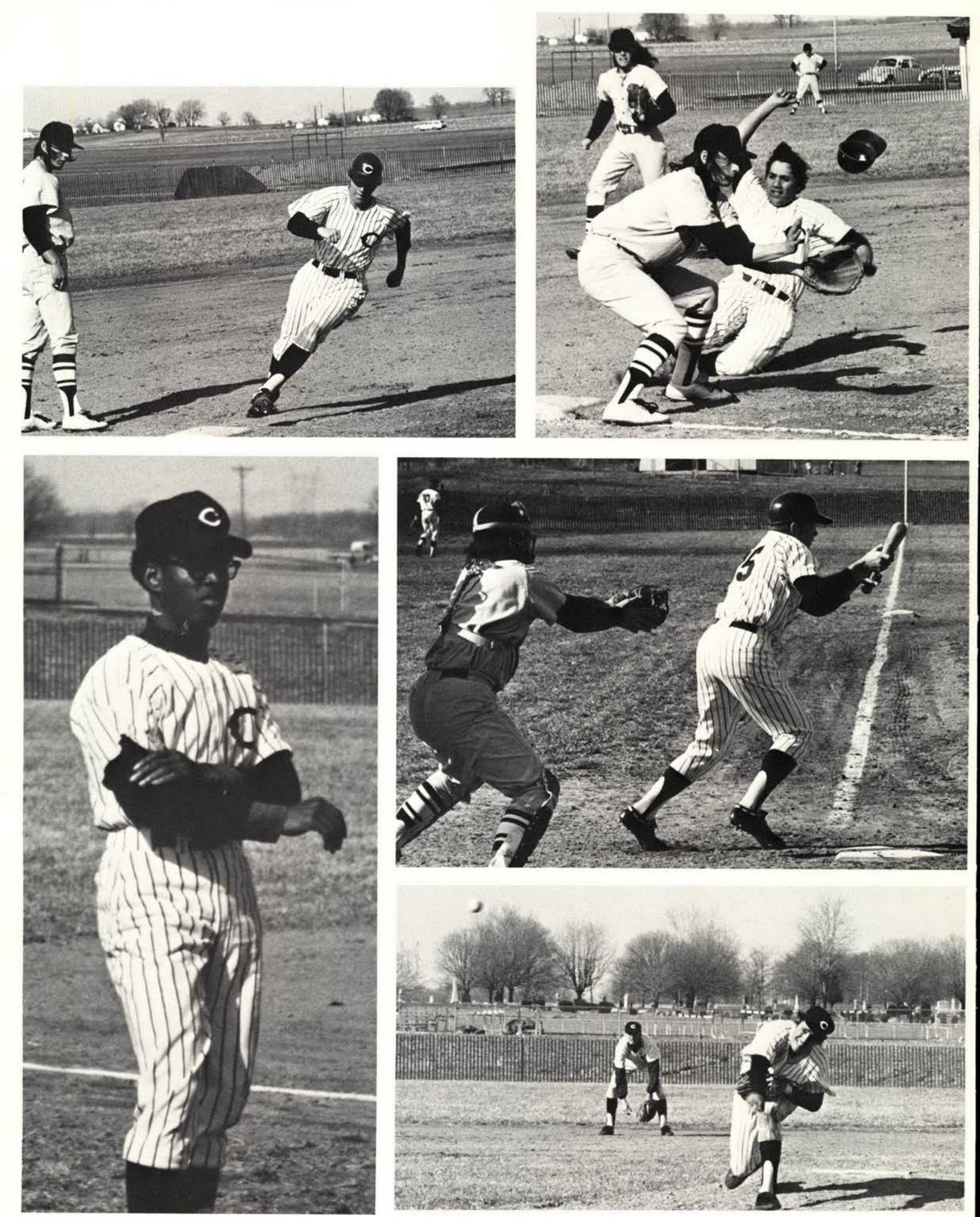



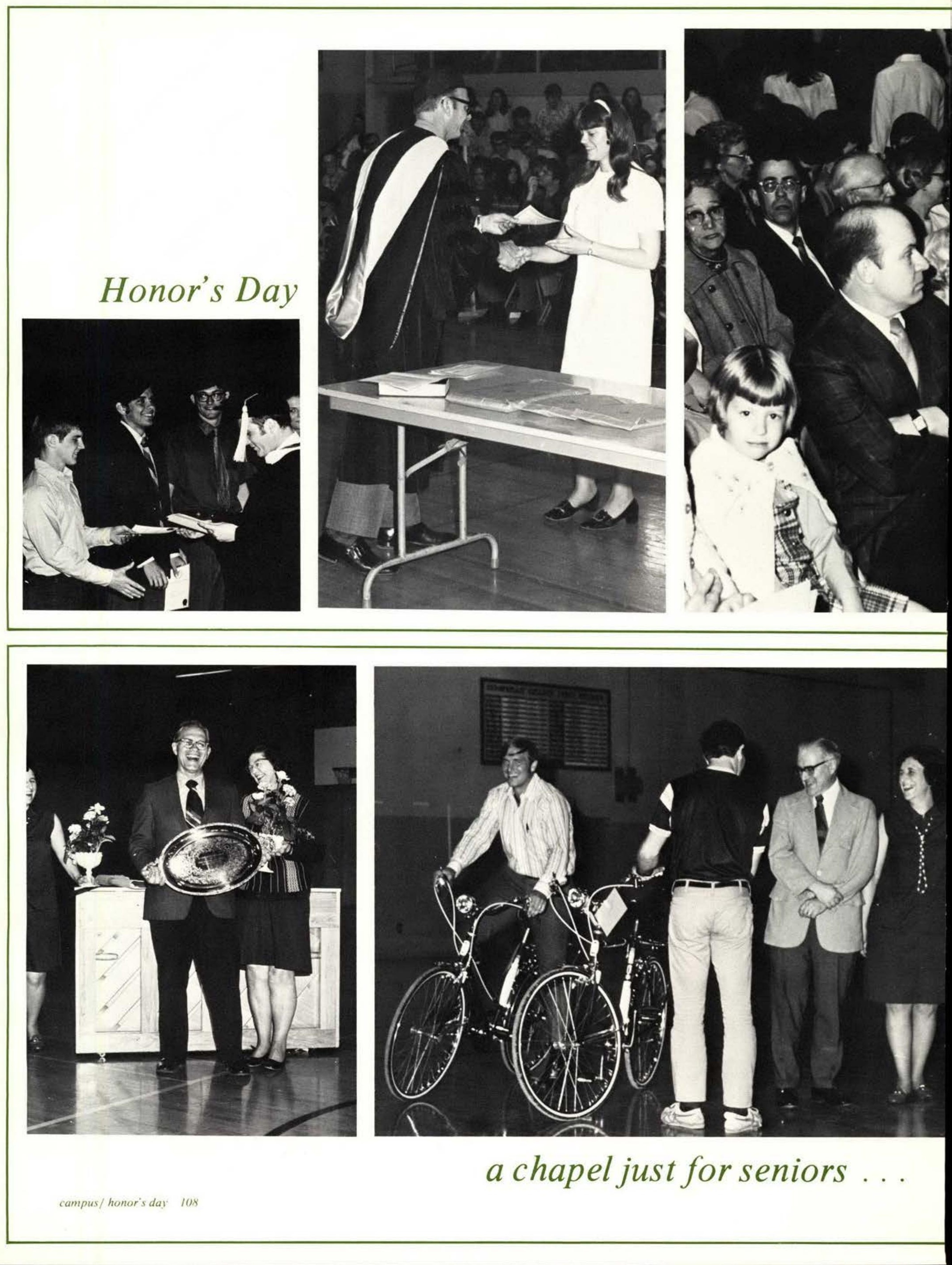



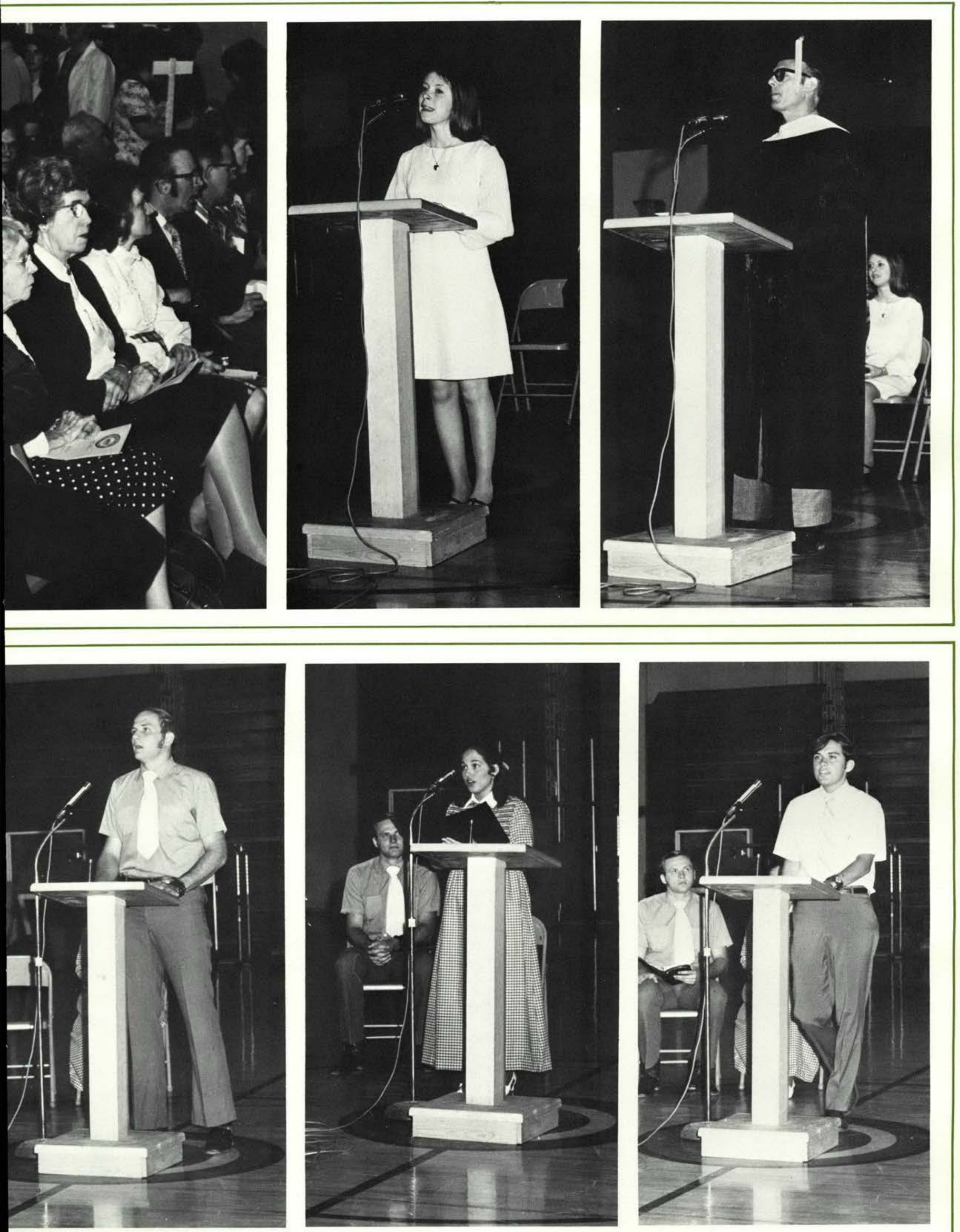

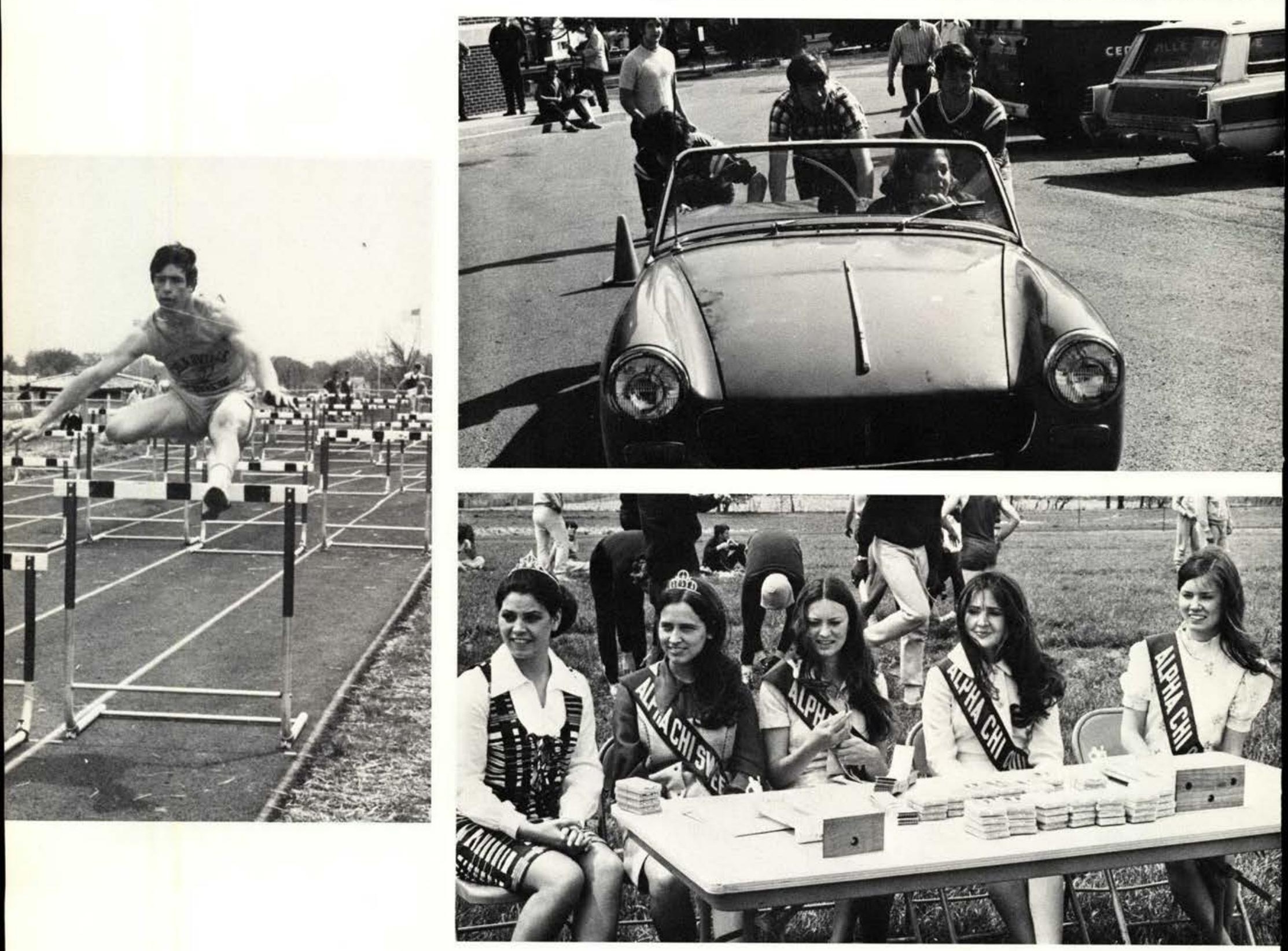

THE DAY OF THE CEDARS 


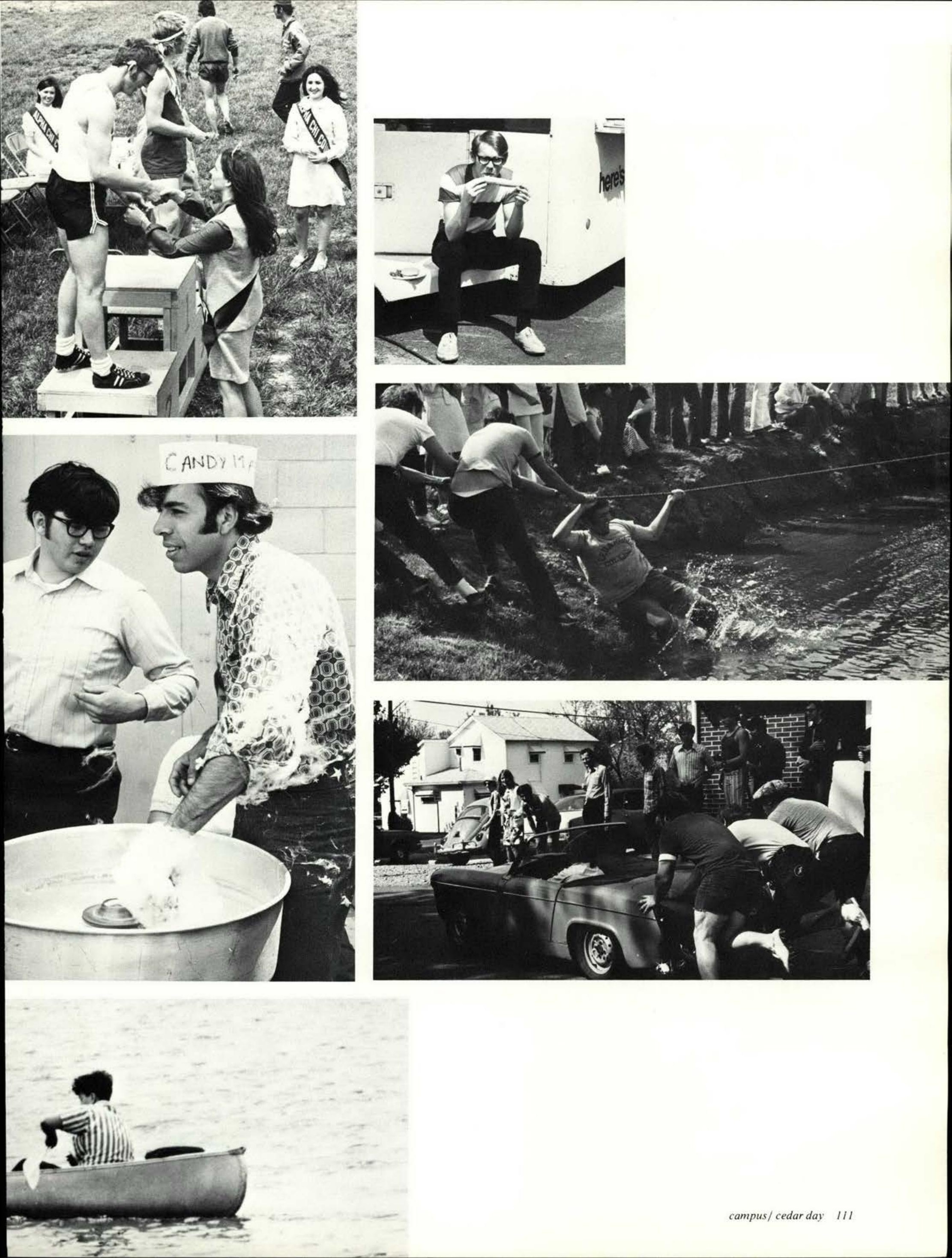



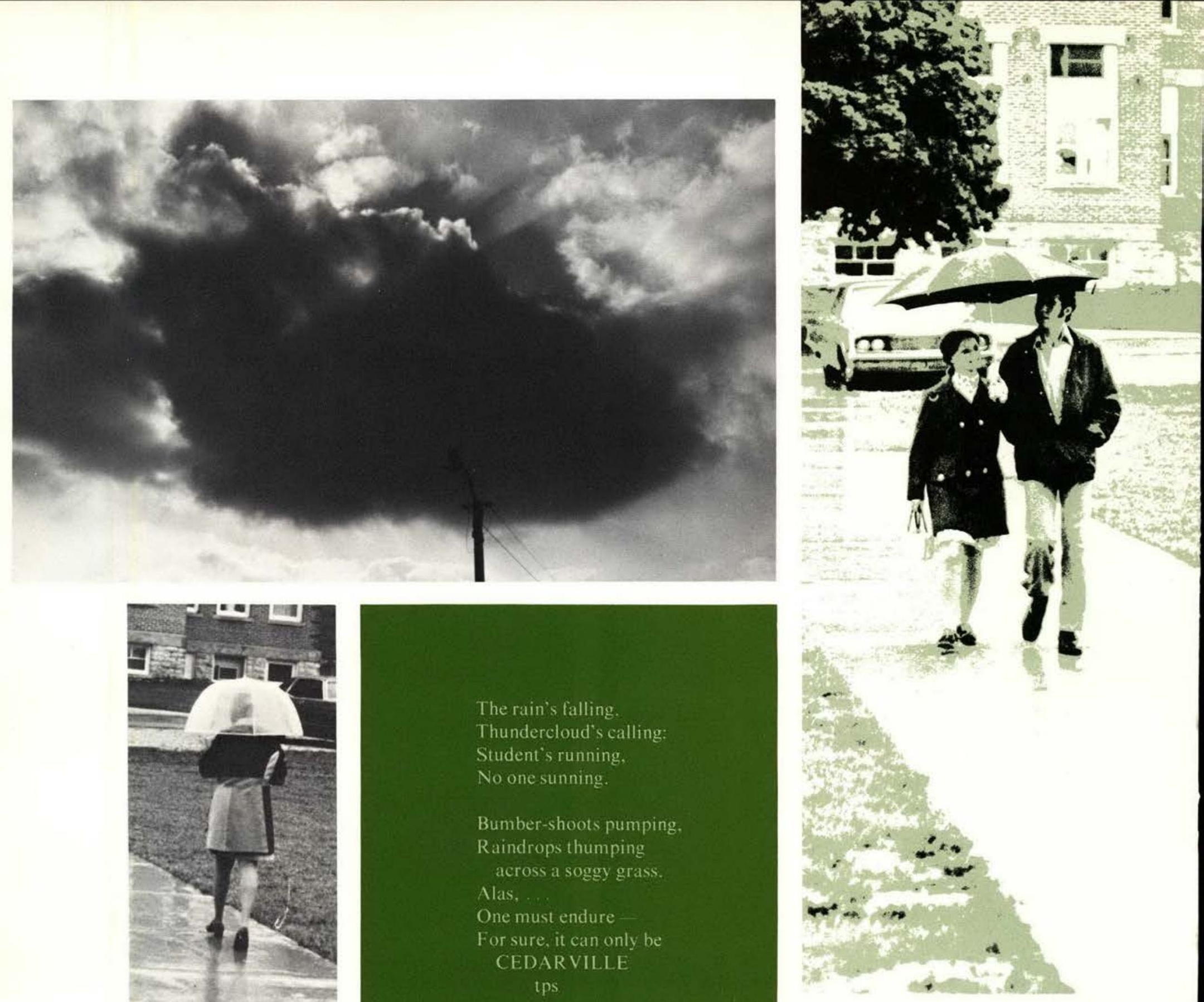


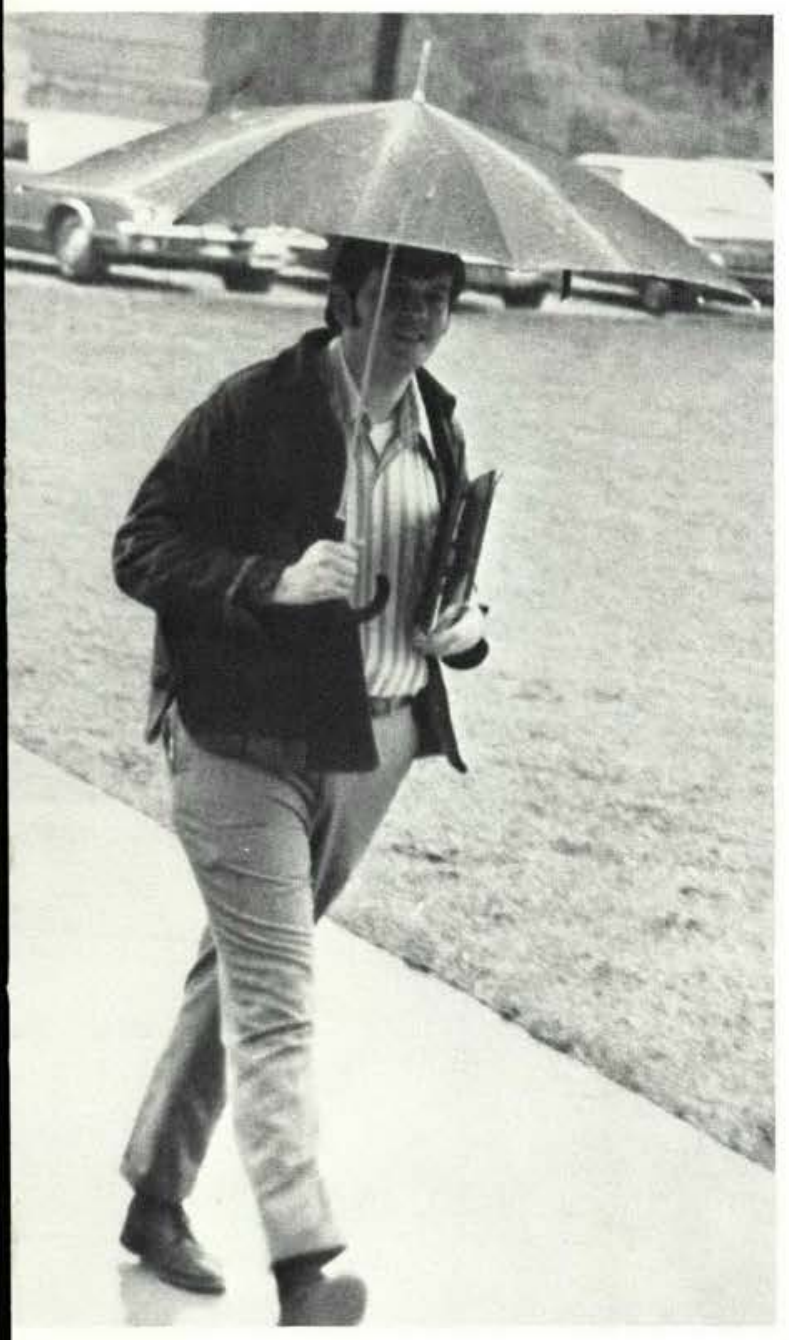

rain, rain, go away ...
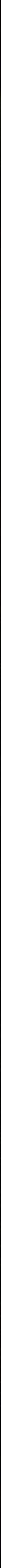


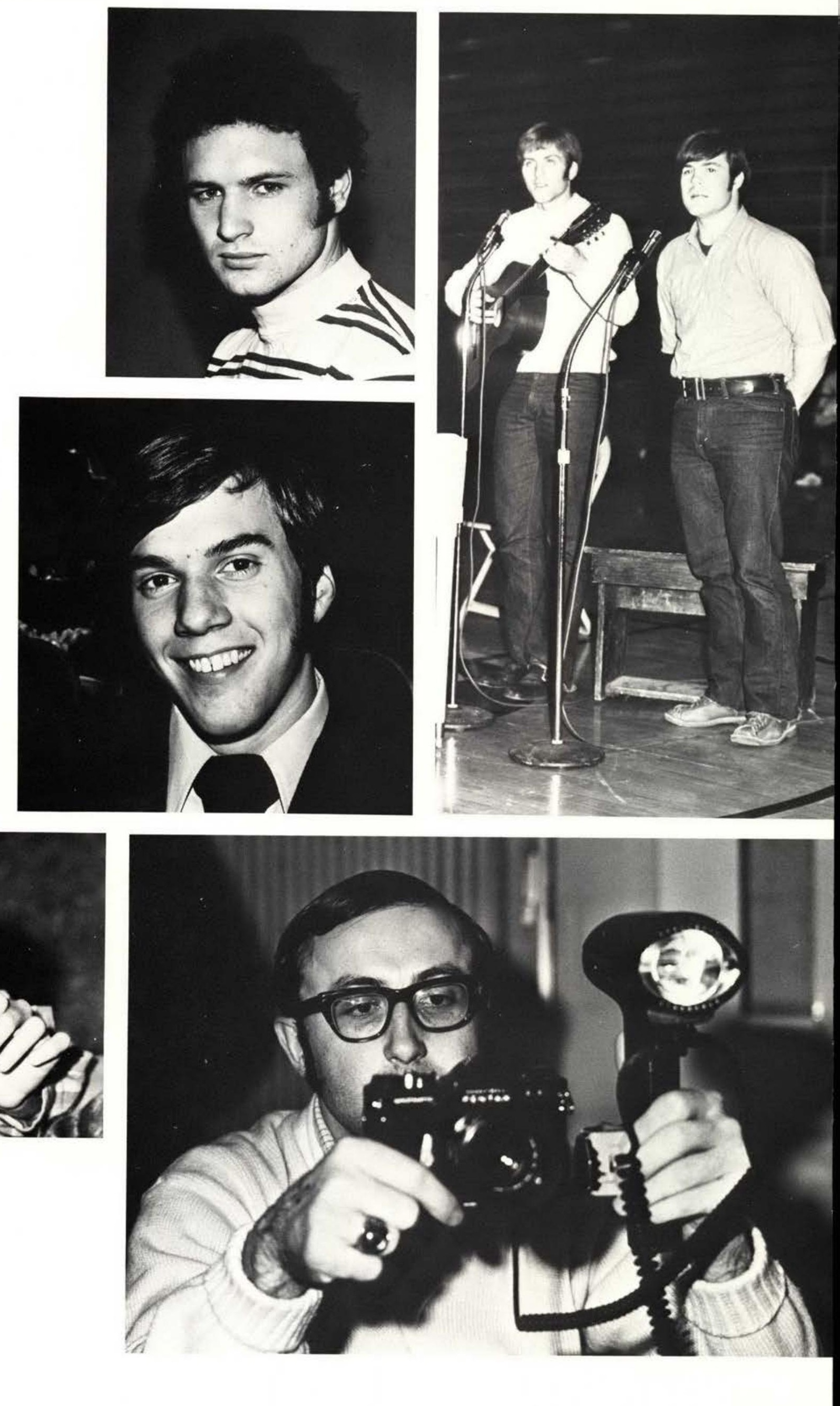




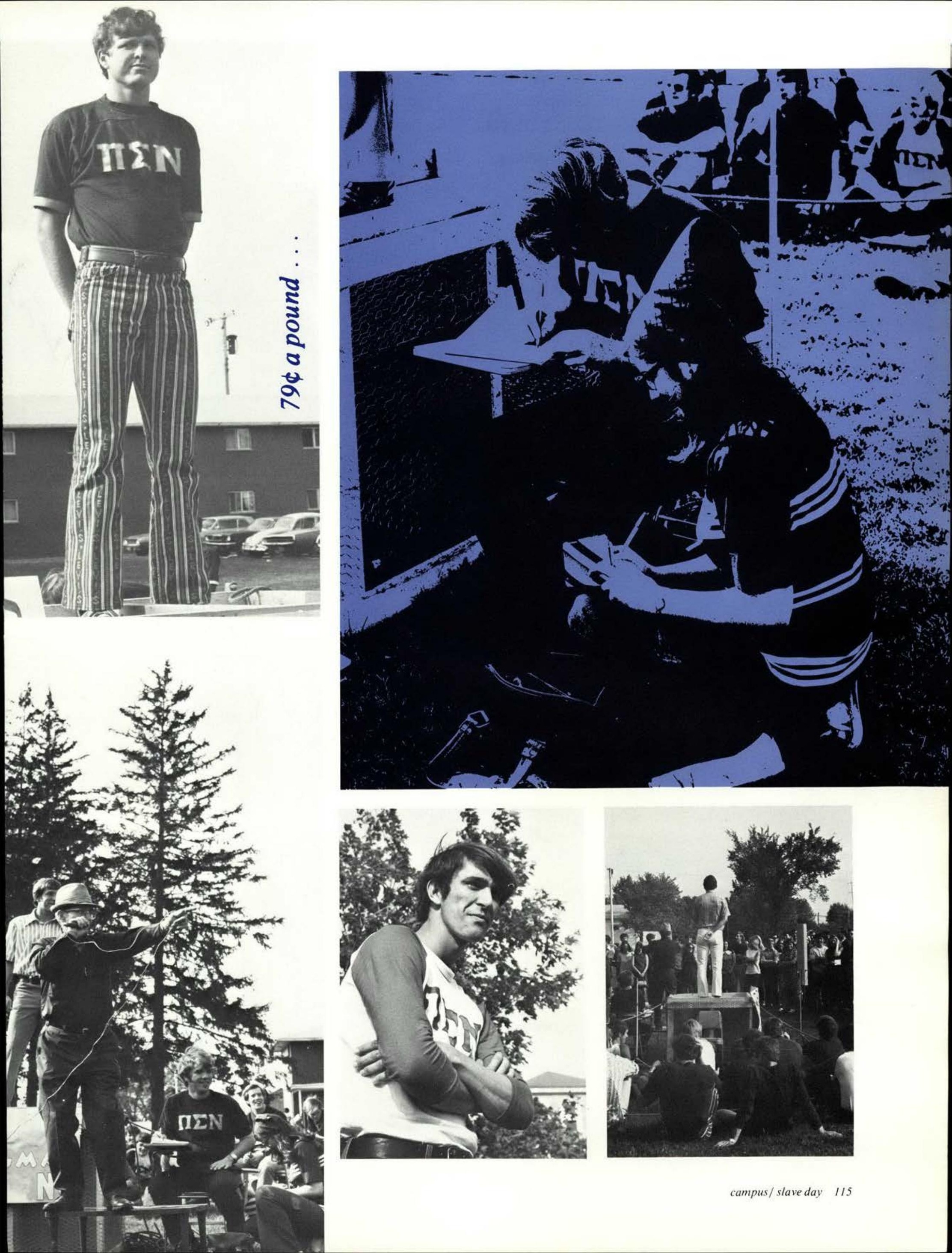





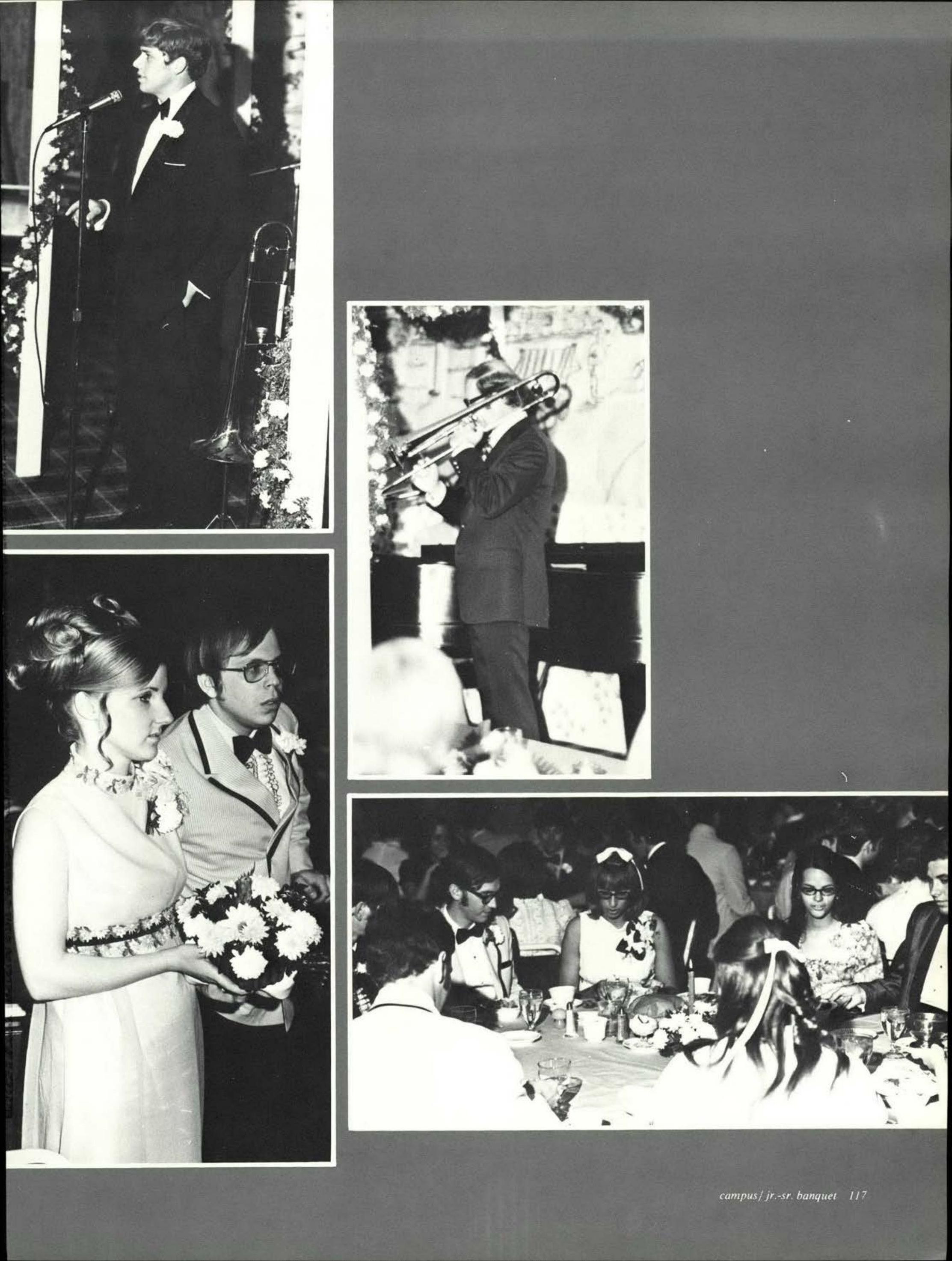



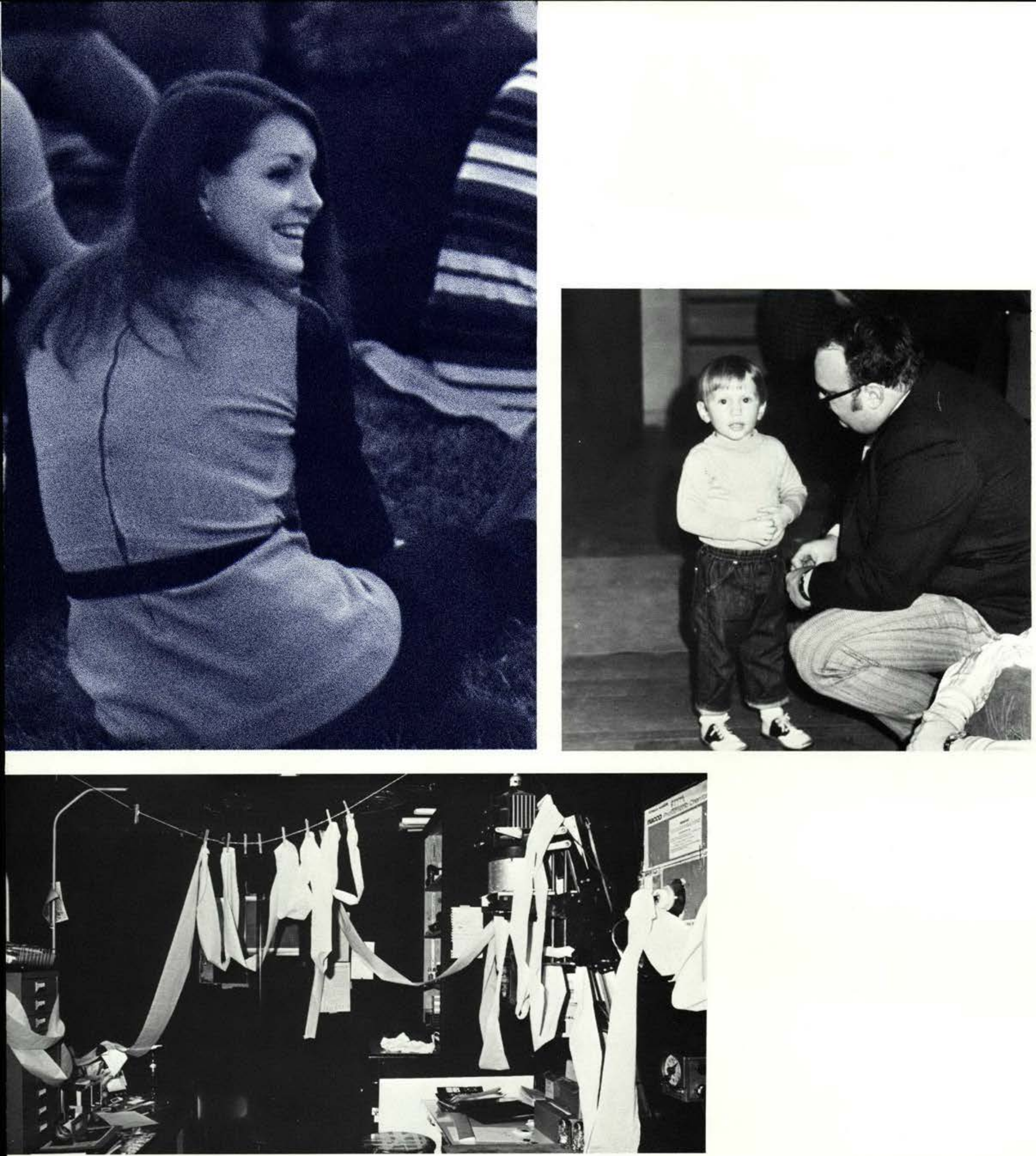

college students sometimes go to extremes to keep themselves busy... 
arrival ... moving ... registration ... initiation ... homecoming ... fall bible conference ... new friends . . classes chapel ... professors ... cafeteria food christian service ... kappa delta chi vespers ... cross country ... harvest of harmonies banquet ... fall becomes winter ... visits to the library ... papers ... books ... trips to the snack shop ... basketball ... artist lecture series ... wrestling ... winter becomes spring . . beach evangelism ... swordbearers ... rain and umbrellas ... inter-campus mail ... concerned faculty ... north central and accreditation ... clubs ... organizations ... missionary conference ... music recitals ... whispering cedars ... grand feast of cedarshire ... spring plays ... rubber raft trip ... sunshine and sunburns . .. tennis ... track ... bike rides ... spring fever ... water fights ... dips in the lake ... 
cedar weekend ... picnics . . studying at john bryan ... junior-senior ... last minute reports ... little sleep ... cramming for - finals ... gathering your belongings ... packing them up ... saying goodbye to 9 months of your life ... all part of our school year ... you could sum it up in one word . . . a word we all know so well ...
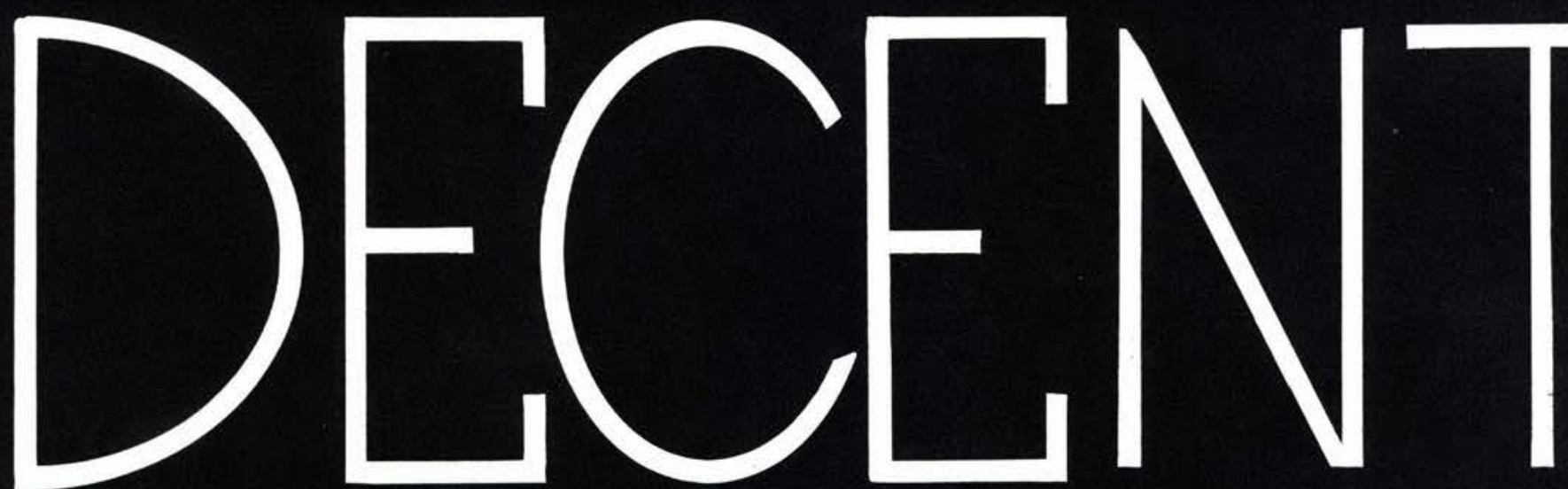


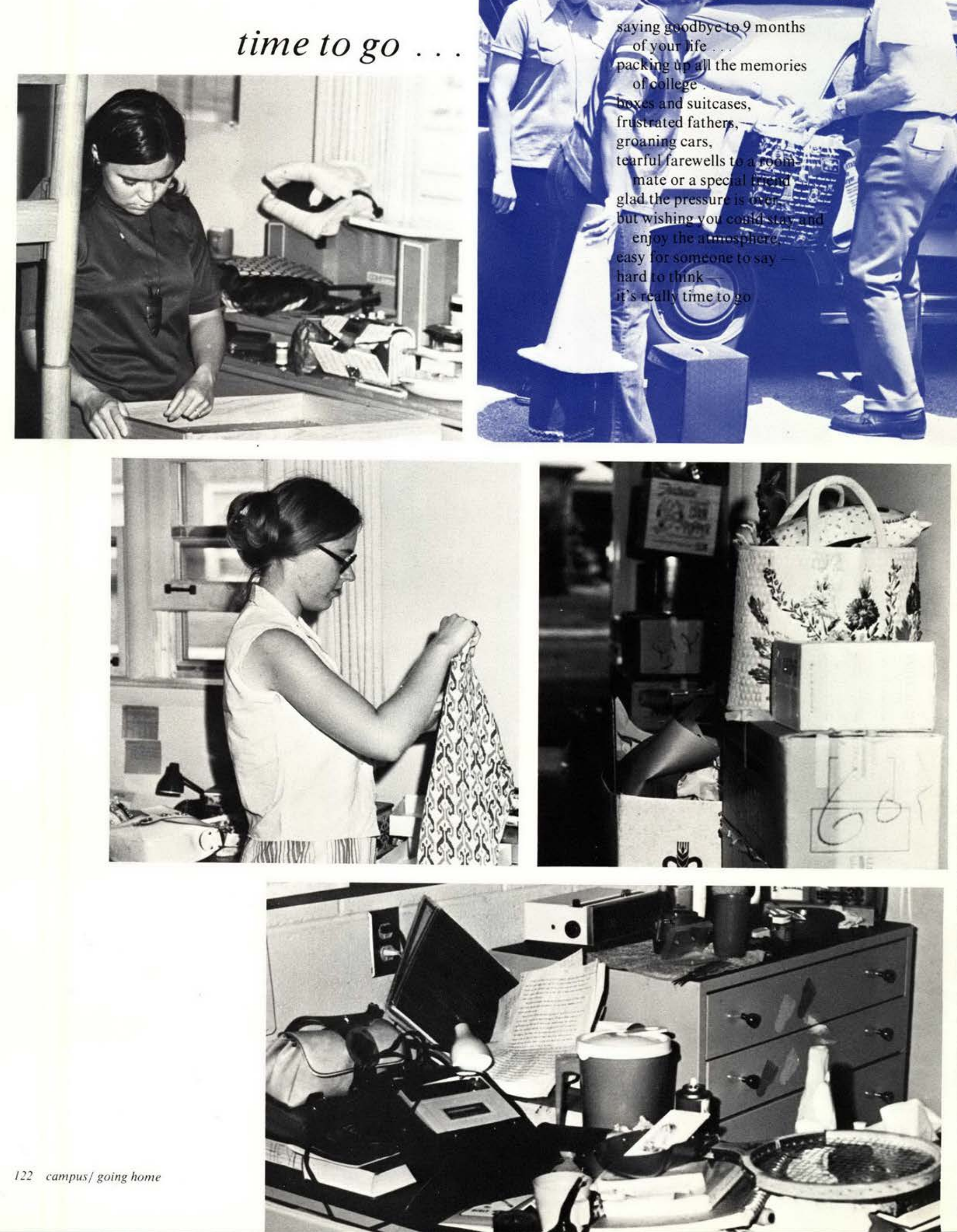




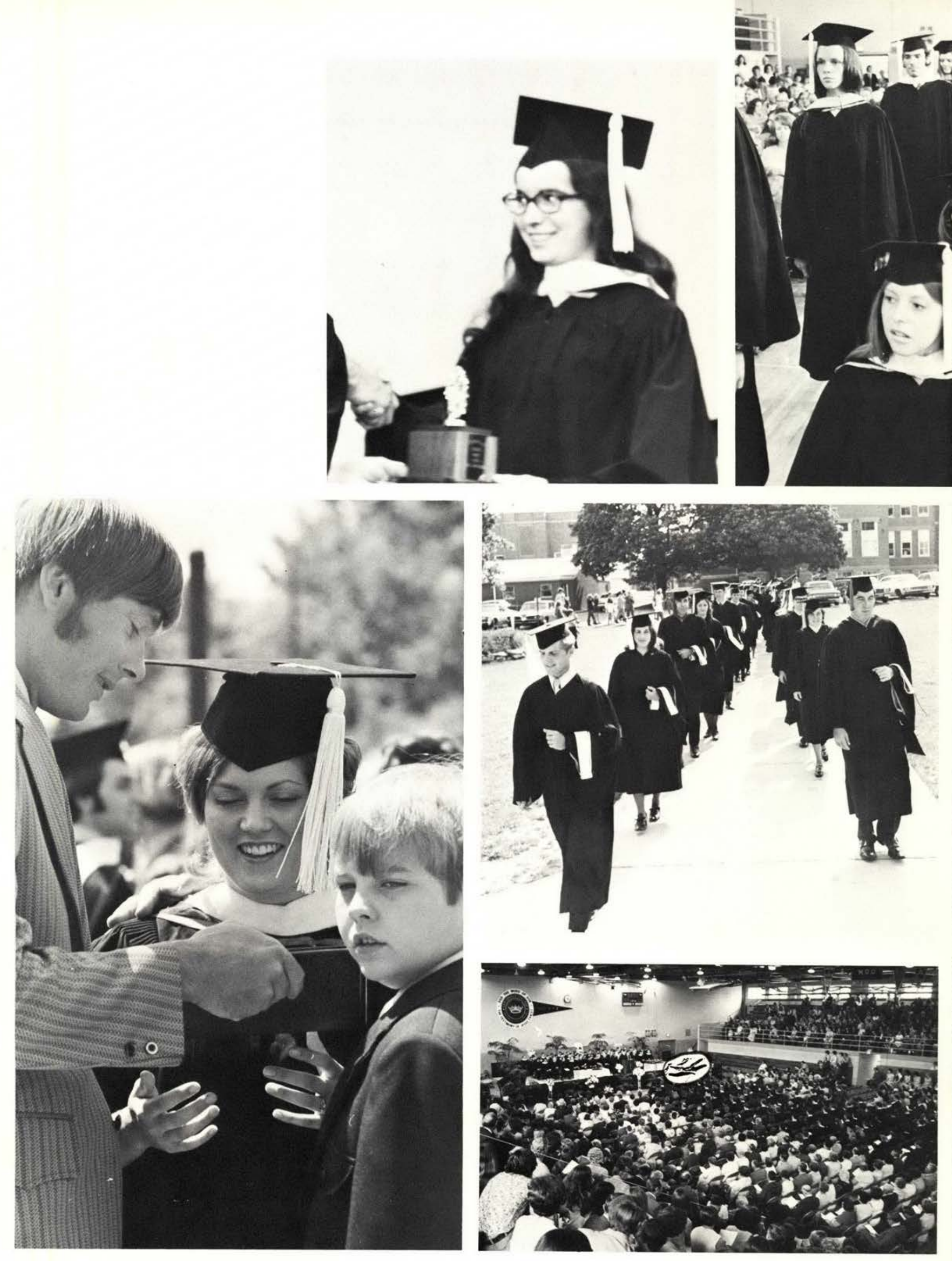




\section{$\operatorname{son}^{2}$ 憵 \\ N}

7. t.

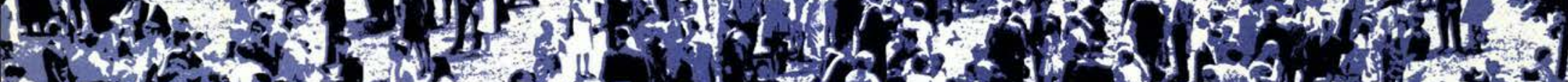
(1)

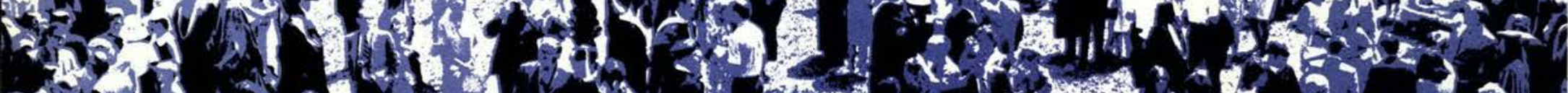
25. 1 (5) (1)
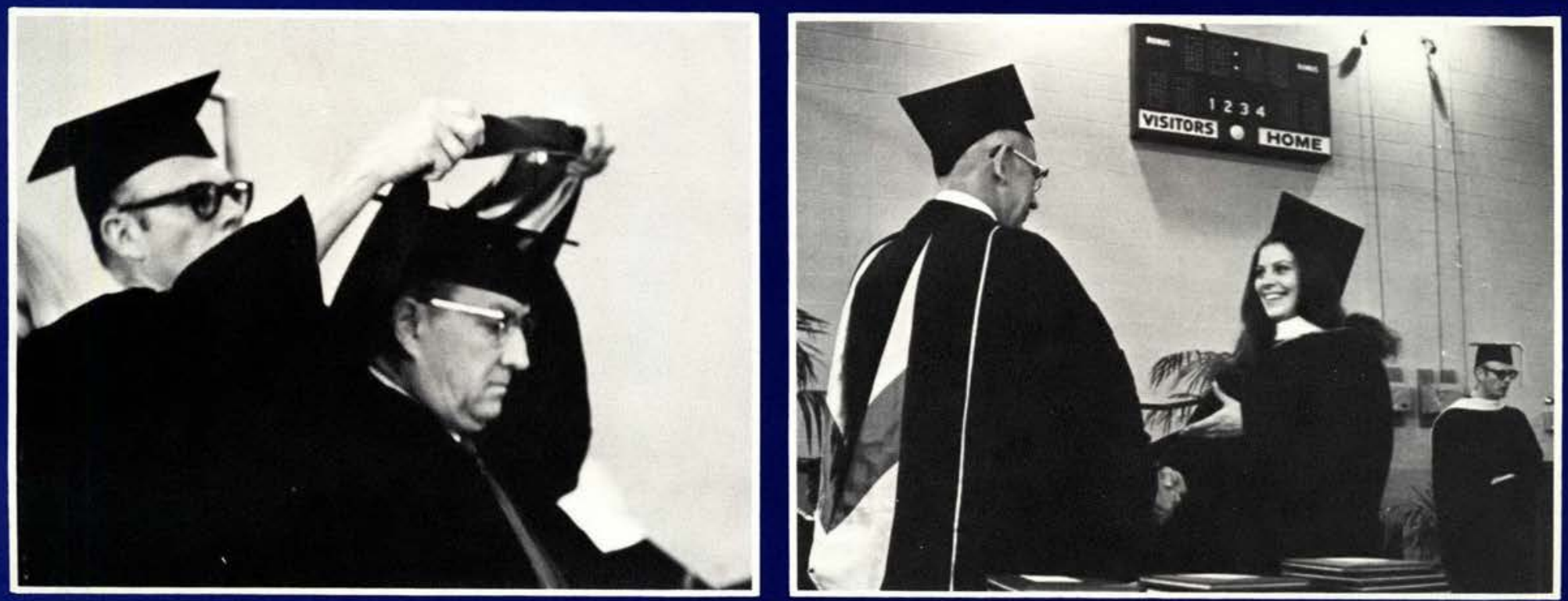

What $A$ Day, What $A$ Year, What $A$ Life, Good-by

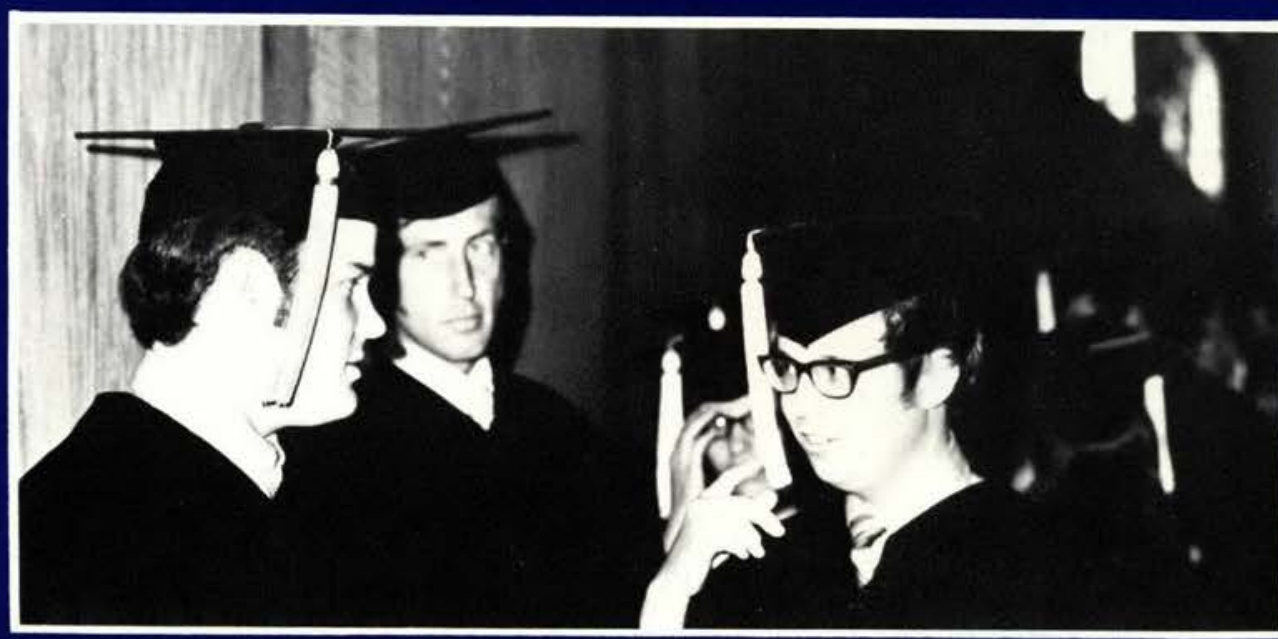



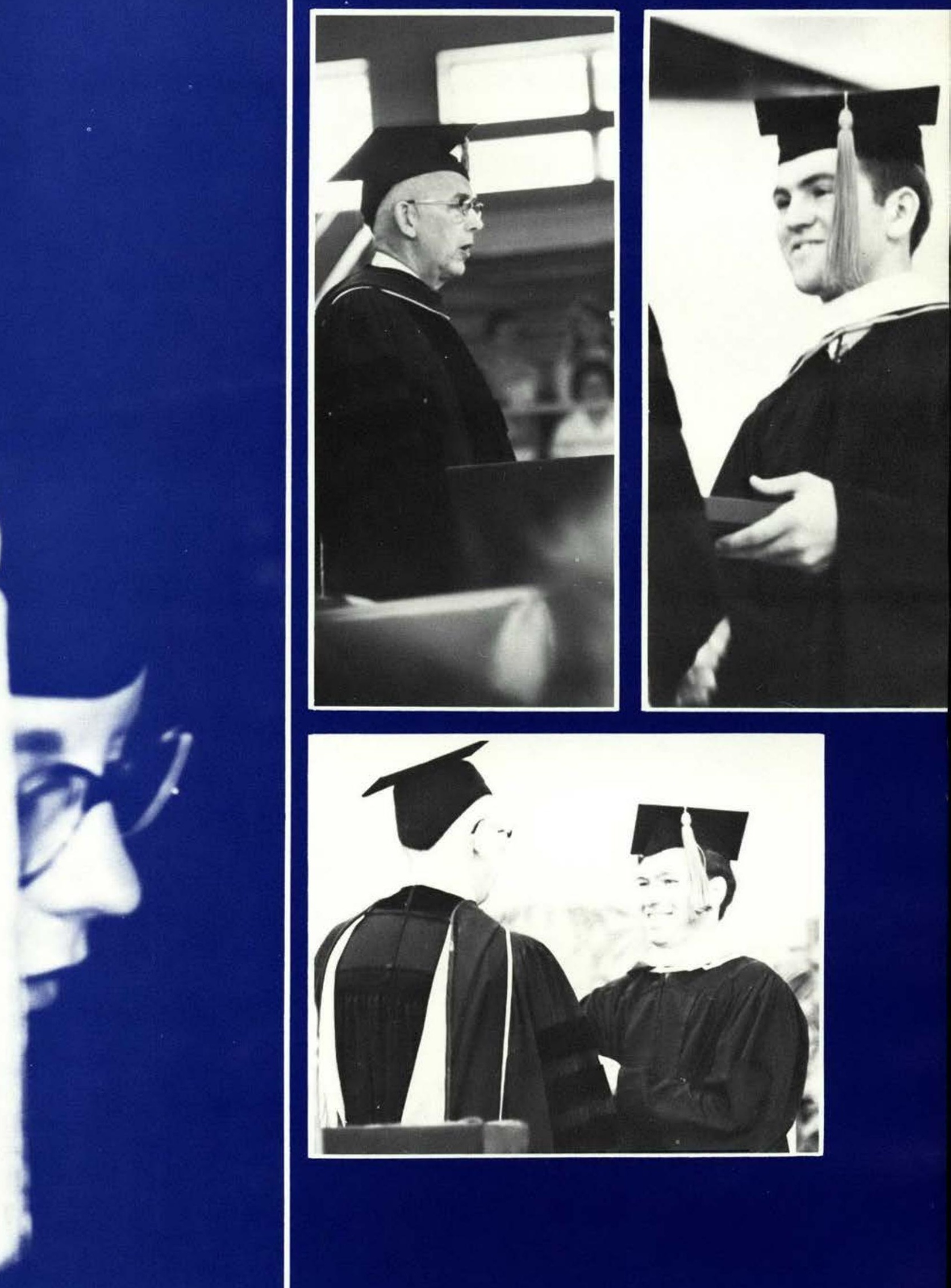


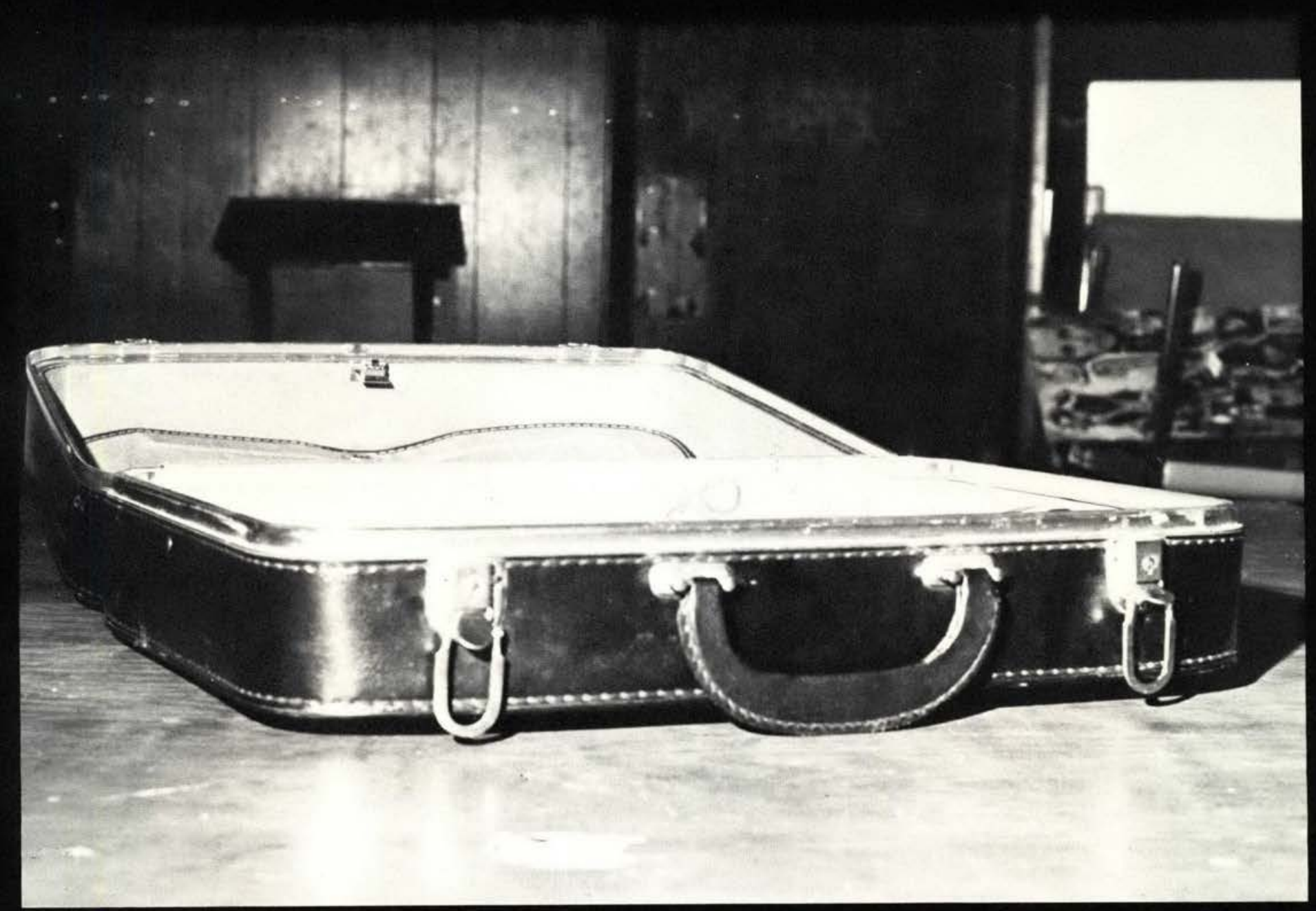





\section{MIRACLE Table of Contents}

Leaders . . . . . . . . . . . . . . . . . . 130

Personalities ................... 138

Affiliation ................... 168

Diversions ..................... 180

Advertisements ................. 106

Carol Bierbaum, Editor

Bob Mahl, Assistant Editor

Roy Kern, Photography Editor

Glen Huebner, Photography Ass't

Dr. Donald Baumann, Advisor

Mr. Charles Miller, American Yearbook 


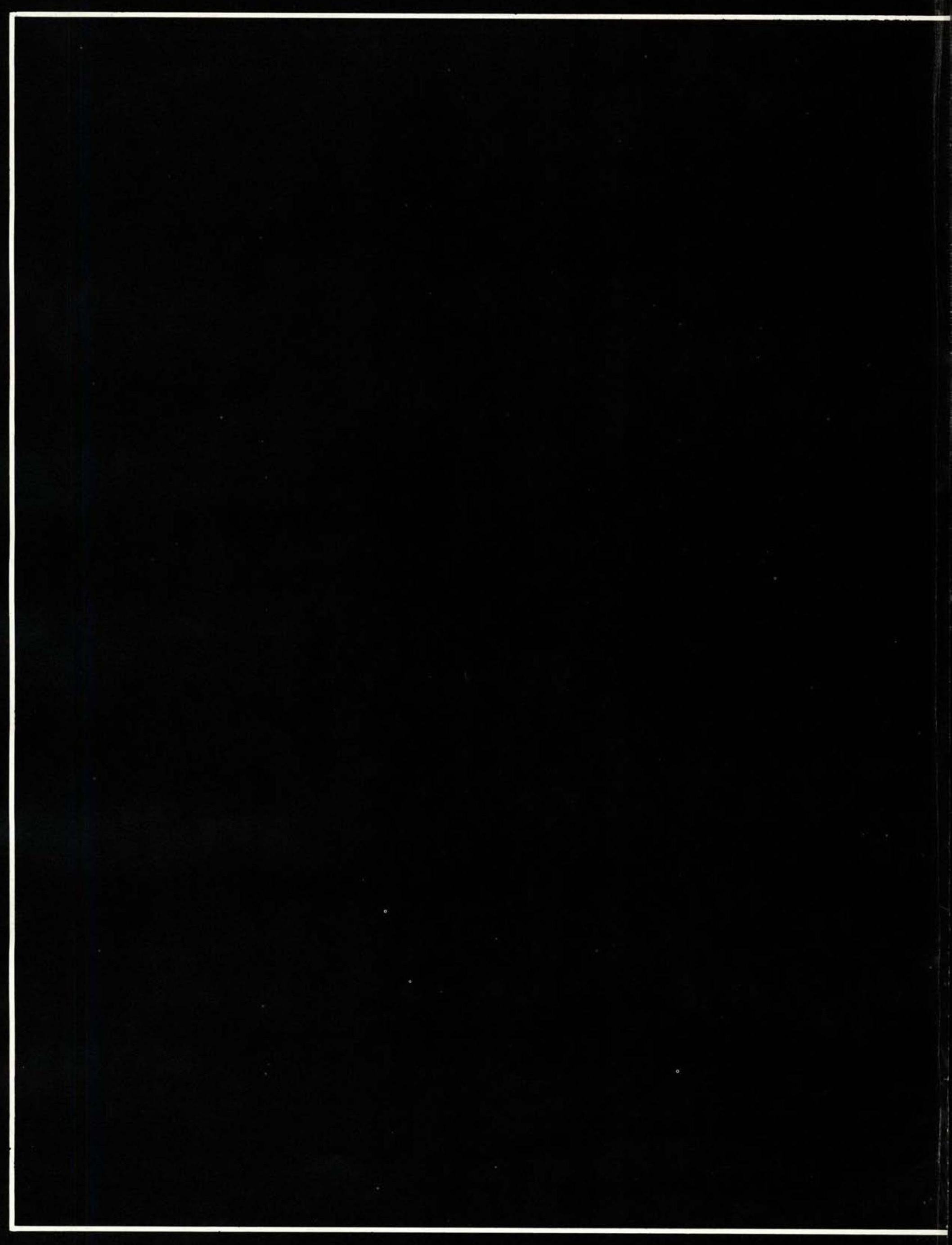



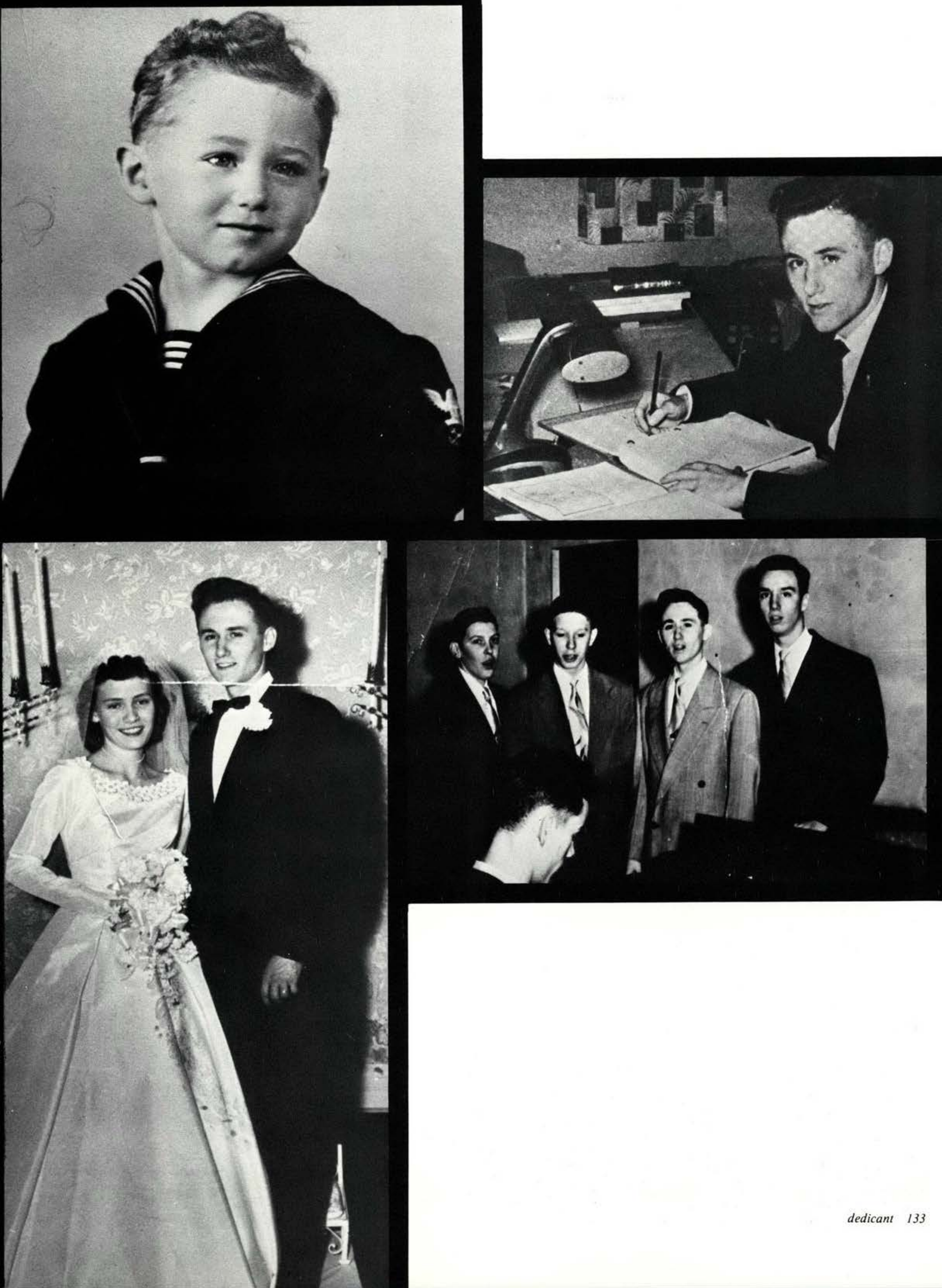


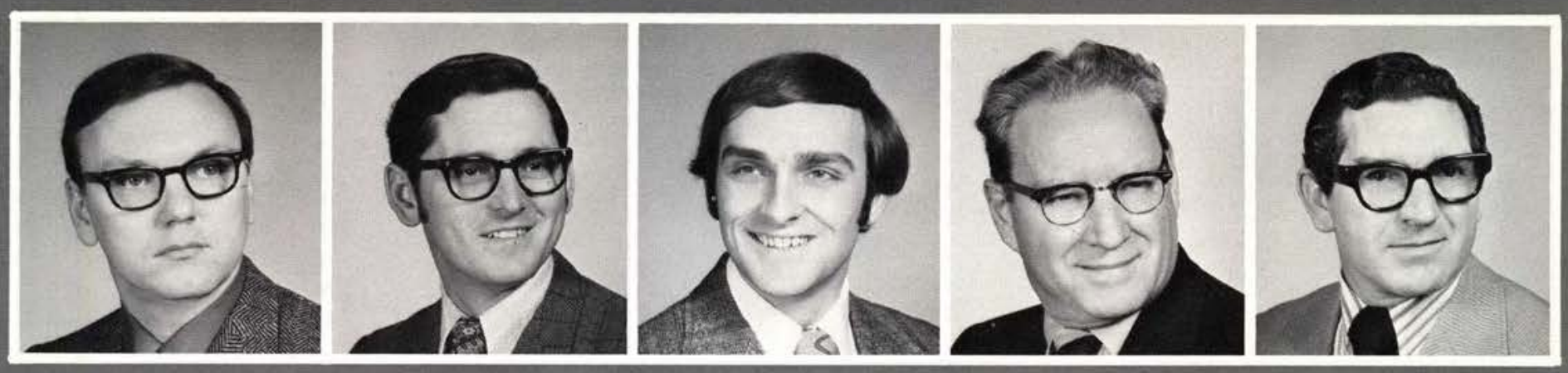

Robert Abbas

Dr. Ager

Dept. of Education

Lyle J. Anderson

Mead C. Armstron

Dr. Stan Ballard
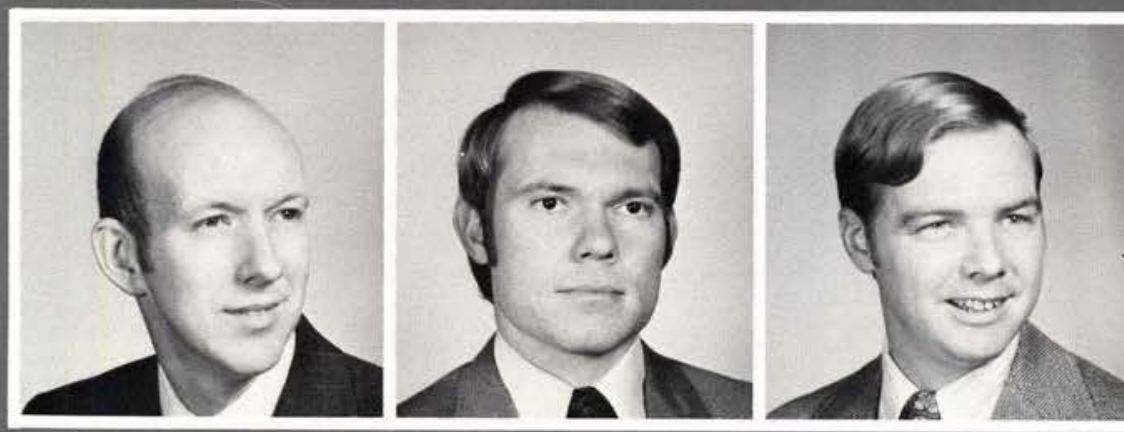

Professor of Bible

Professor of Psychology
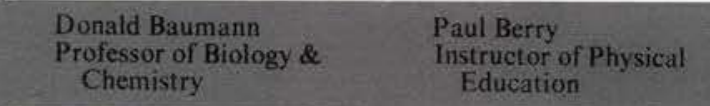

Lynn A. Brock

Reference Librarian

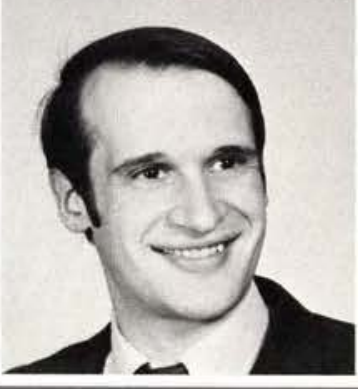

Stephen P. Brown

Reference Librarian

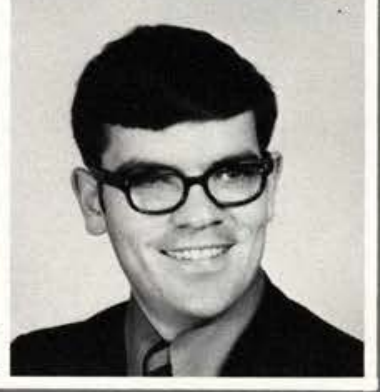

Ty Bryant

Director of Alumn

Relations
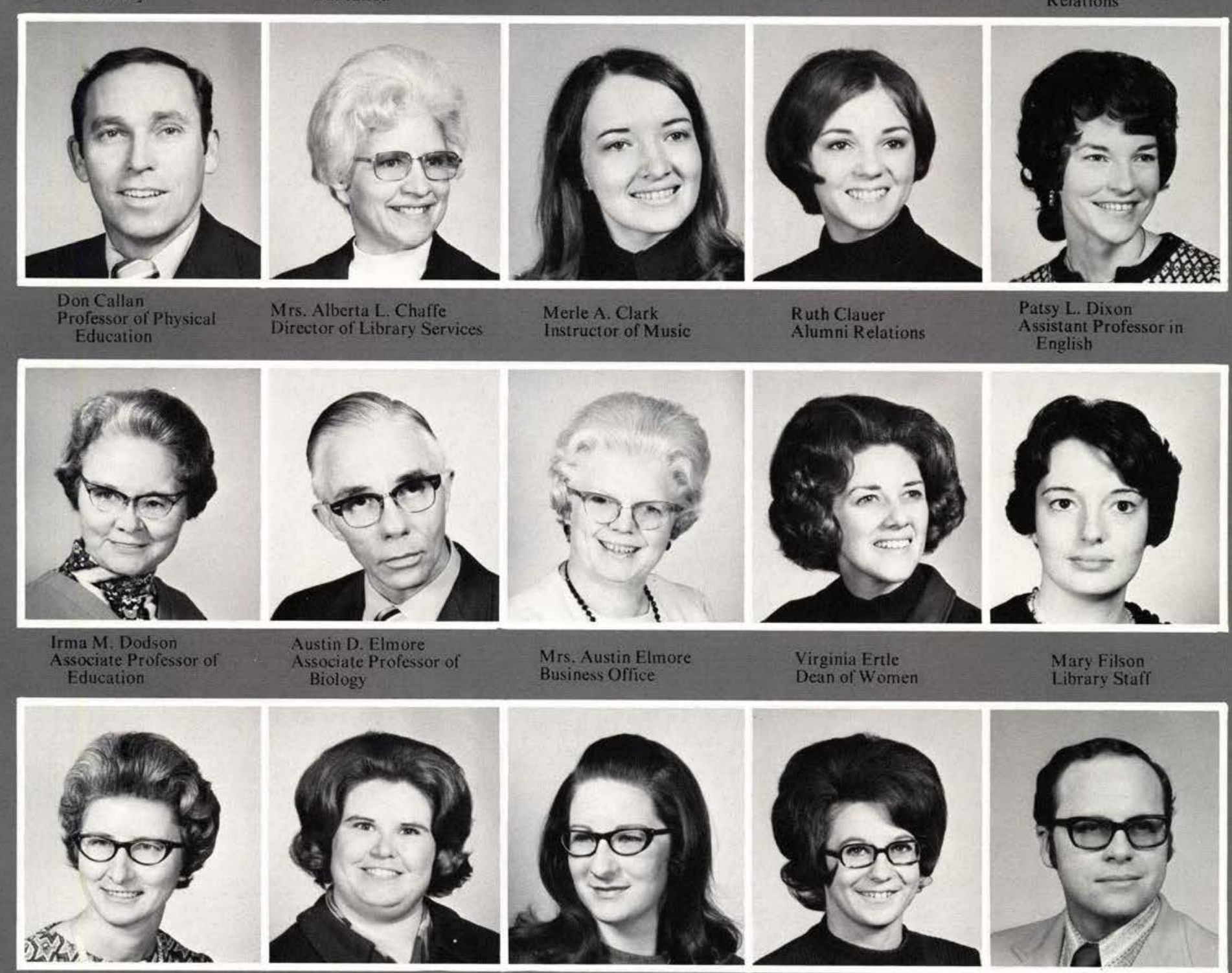

Mary Filson

Virginia Ertle

Library Staff

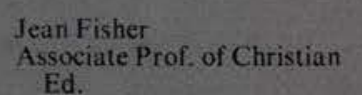

Nancy Fissel

Business Office

Lavena A. Flack

Secretary to the President

Melinda Flack

Health Service

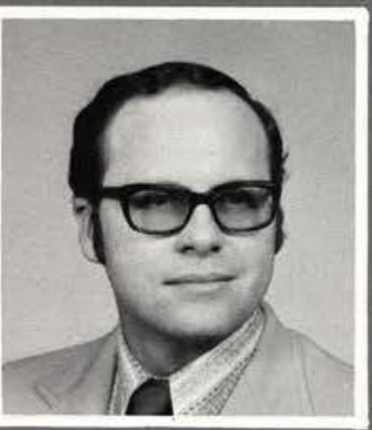

Dwayne Frank

Professor of Education 


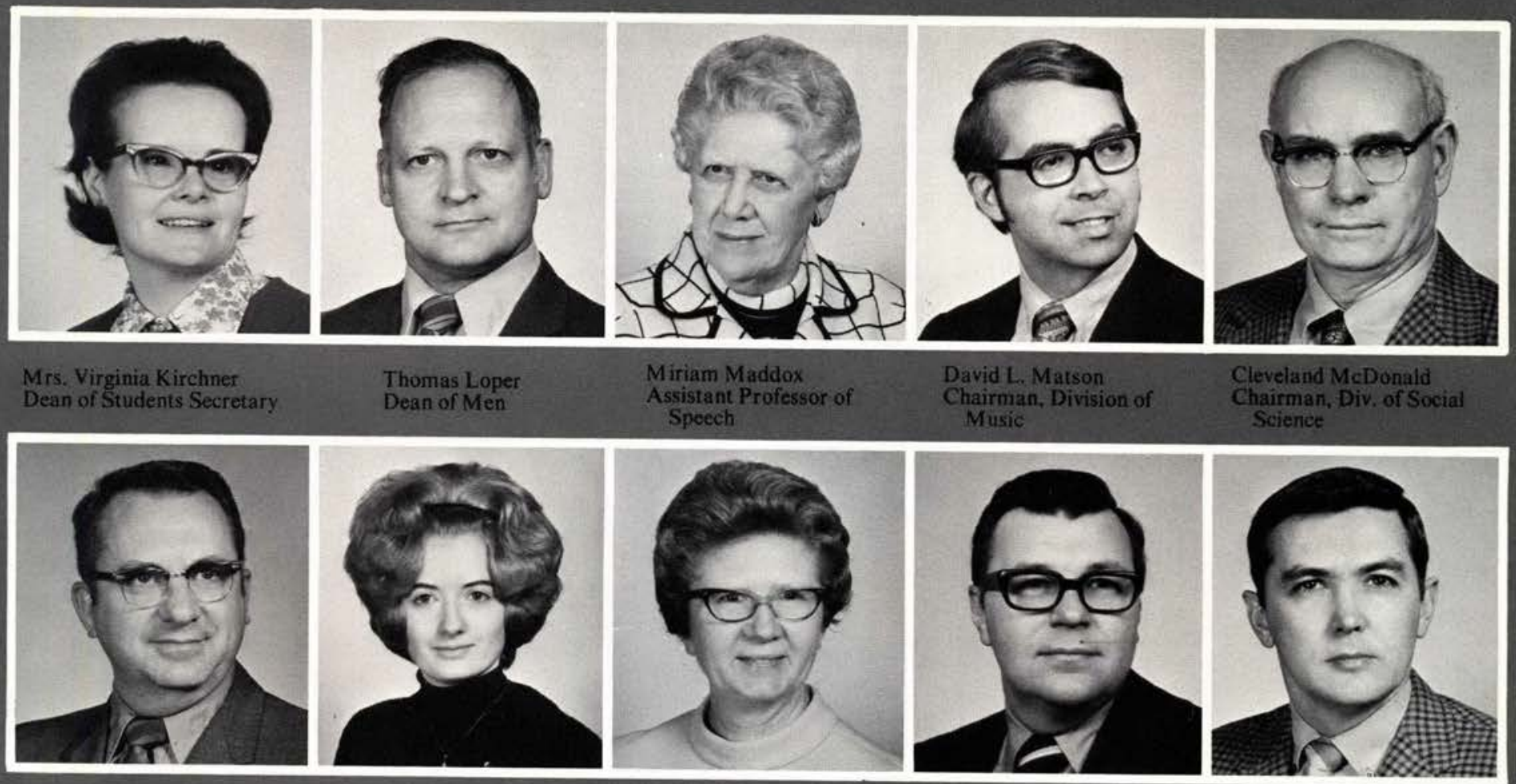

Thomas Lope
Dean of Men

s.

Speech

Chairman, Division of

Chairman. Div. of Socia

Richard Mclntosh

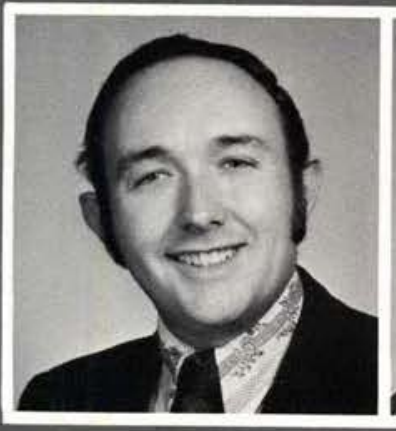

Dr.J. Murray Murdoch Professor of History

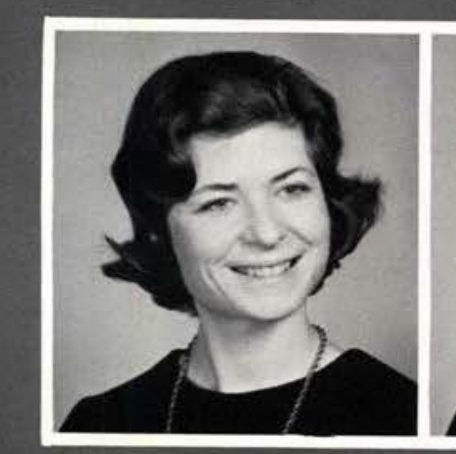

Ken Nichols
Director of Student

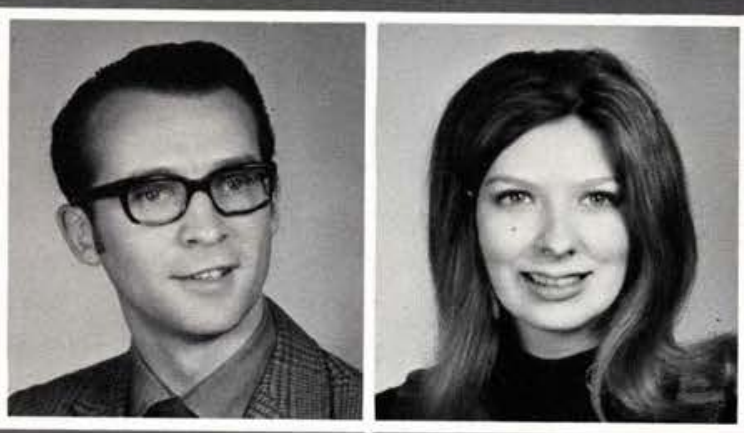

Linda Olson

Student Personne
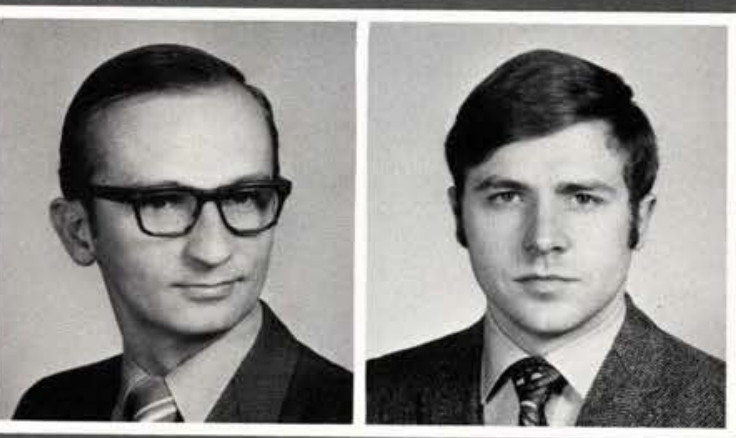

Or. Allen Múnroe Revefeser of Social Science
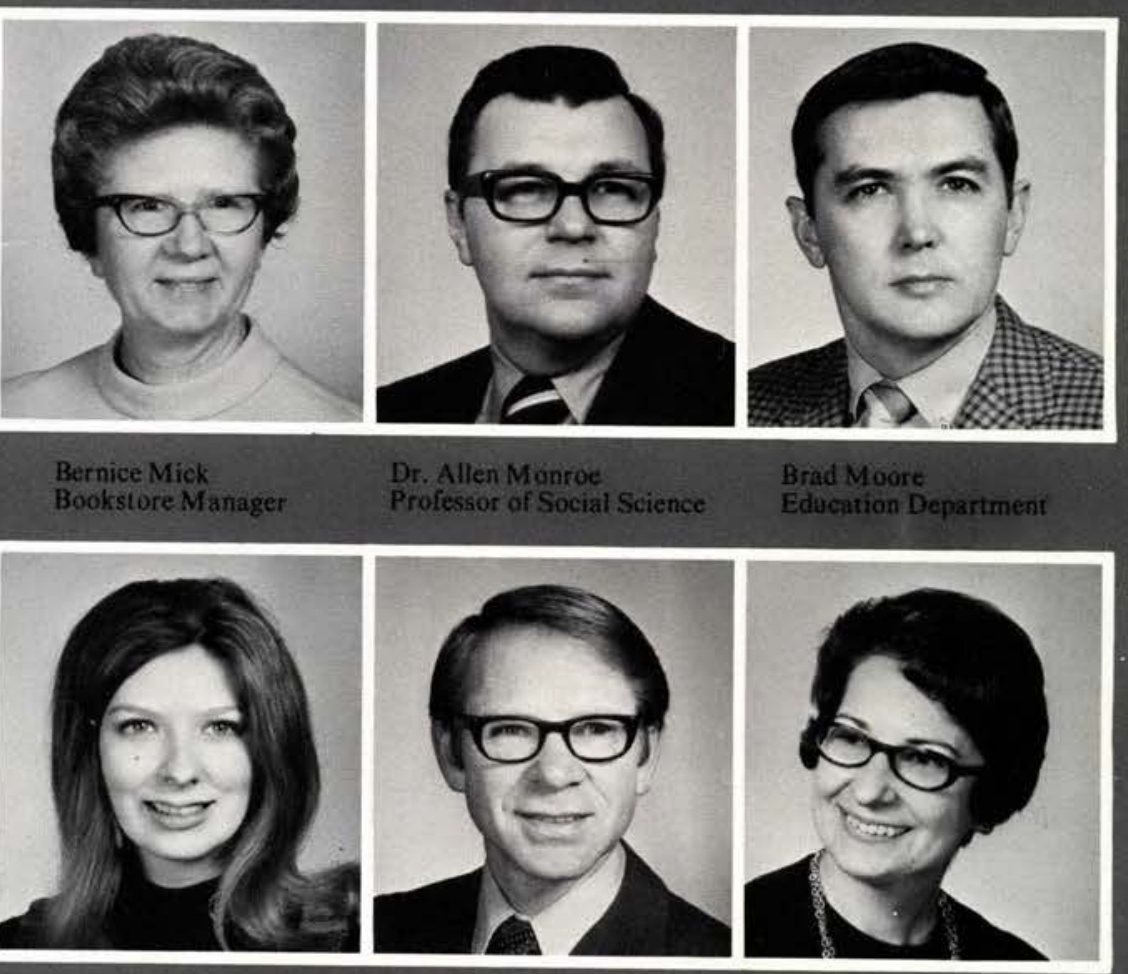

ack Payne

Assist. Prof. of Musi
Marion Payn:

Mailing Dent
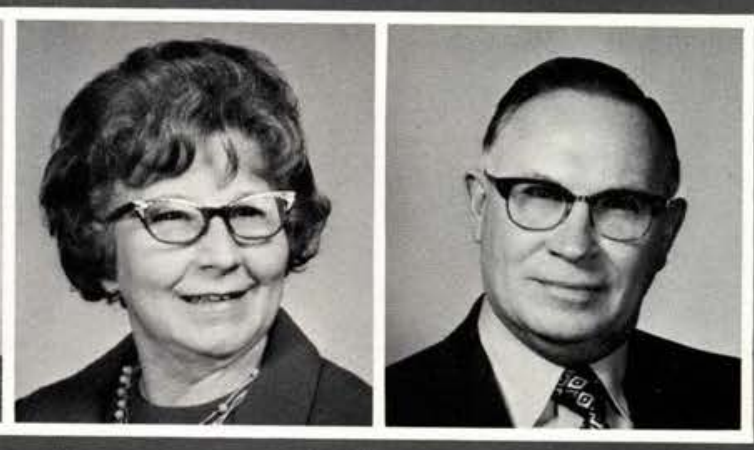

Resident Advisor
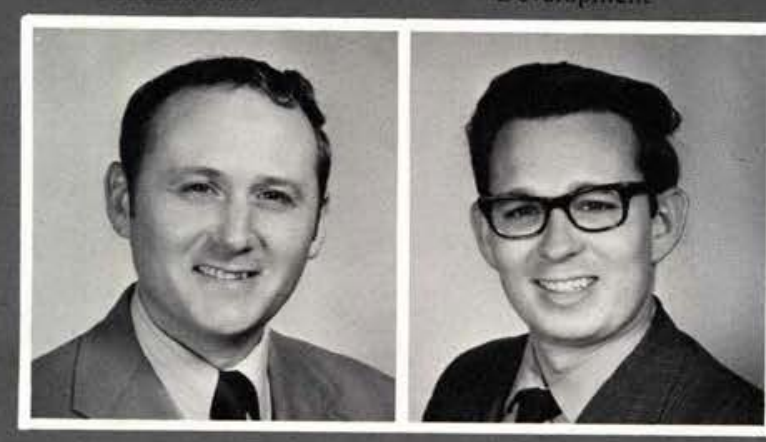

J ames R. Phipr

Mrs: Marlin Rayburn

Marlin L. Rayburn
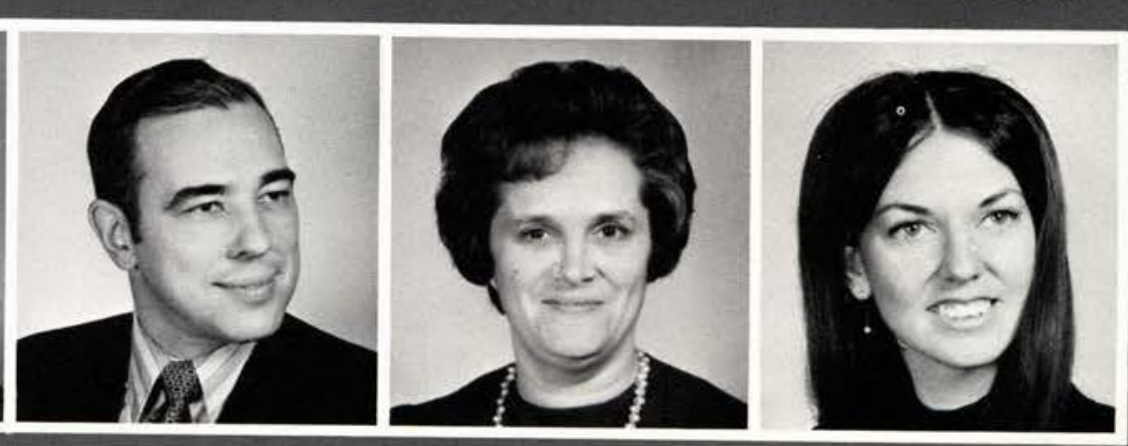

Donald W. Rickard

Jim Rickard

Business Office

Dr. Jack Rigg

Mona Ritchie

Mrs. Carol Rosa

cesid 


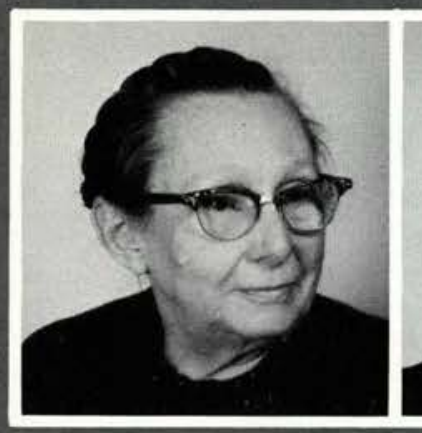

Esther Ruder Library Dept

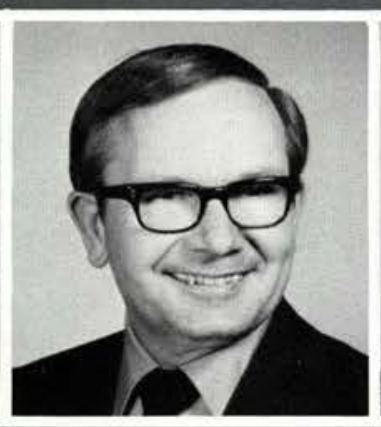

Kenneth St, Clair Business Director

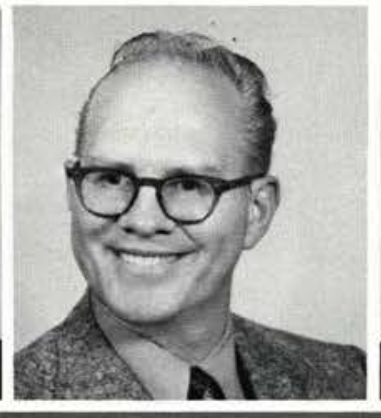

Dr. Jack H. Scott

Prof. Psychology Dept.

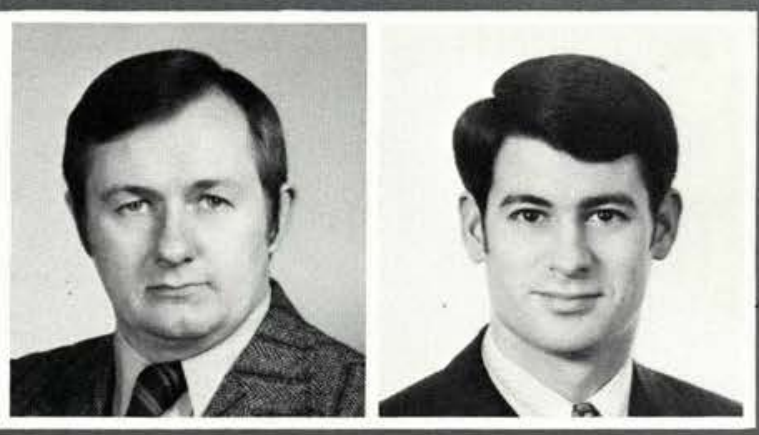

James Seaman

Ass't. Prof. of Business
Stan Seevers

Ass't. Director of

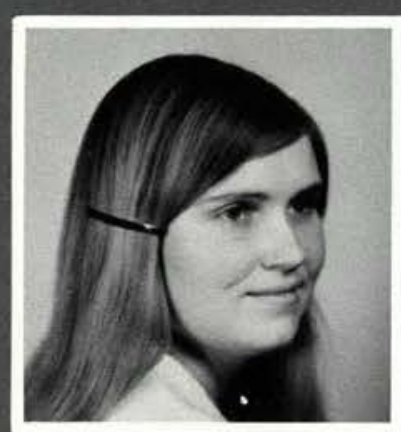

Mrs. Steven Skees

Sec. Christian Service

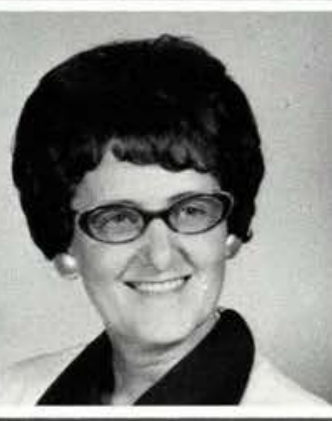

Mrs. Edward Spencer Business Office

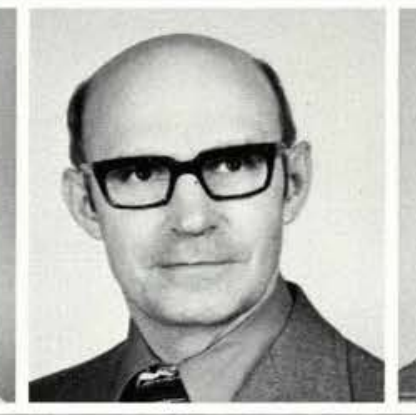

Mr. Edward Spencer Prof. of English

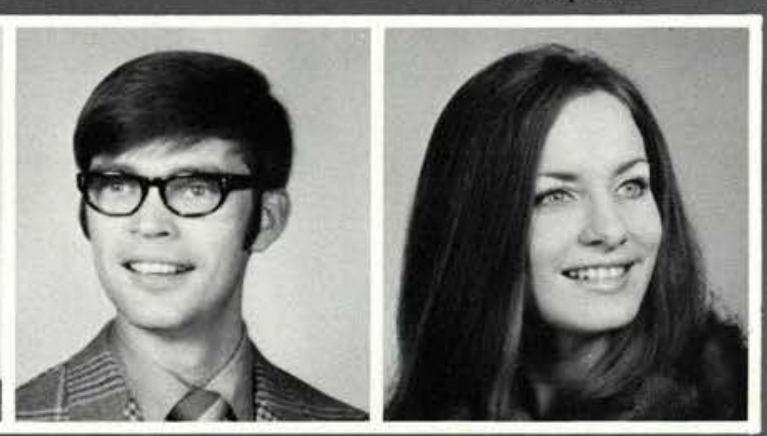

Mr. Fred Stickle Resident Advisor
Miss Judy Strickland

Music Dept.

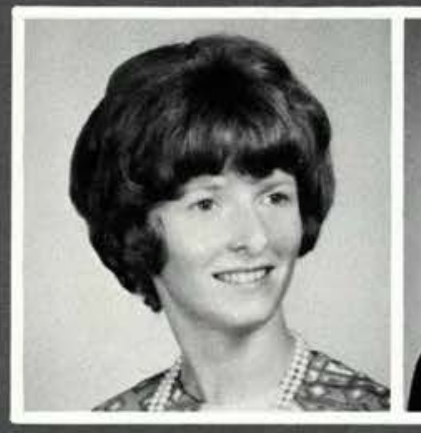

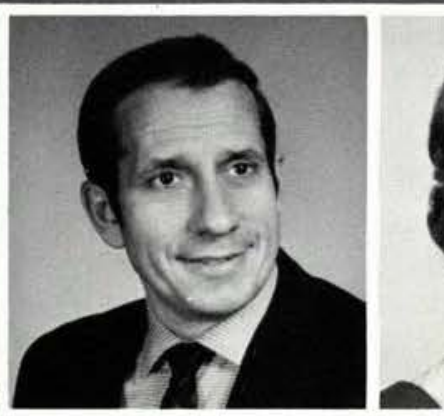

Mr. Lee Turner Director of Development

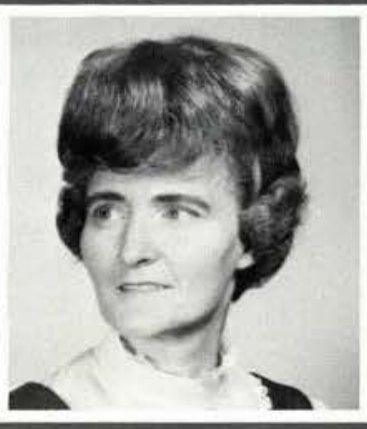

Mrs. Lee Turner Mailing Dept.

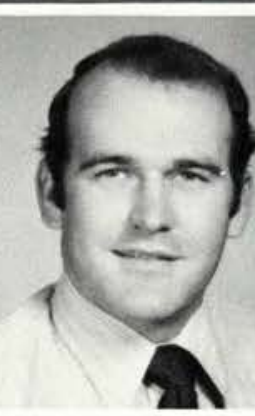

Mr. Richard Walker Director of Intermurals

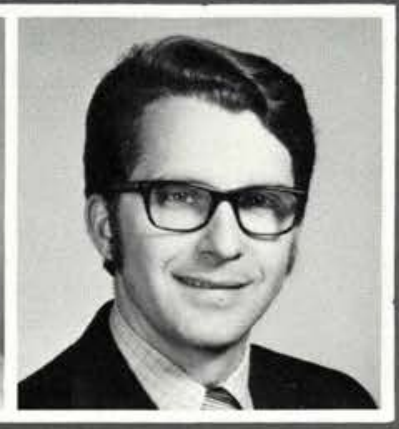

Mr. Ralph M. Werner, Jr. Ass't. Prof. of Music

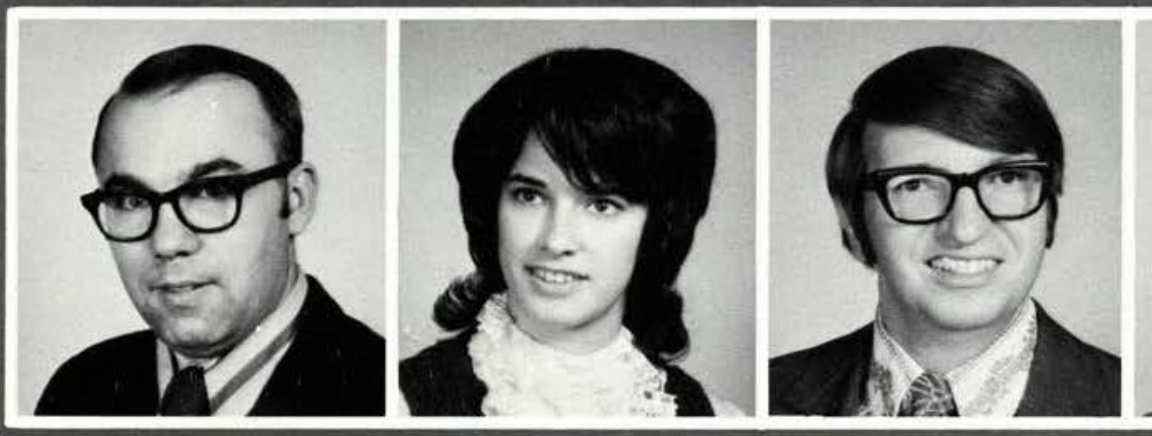

Mr. Daniel E. Wetzel

Prof. of Physics
Linda White Sec. Development
Mr. Donald T. Wilcoxin Ass't. Prof. of Economics

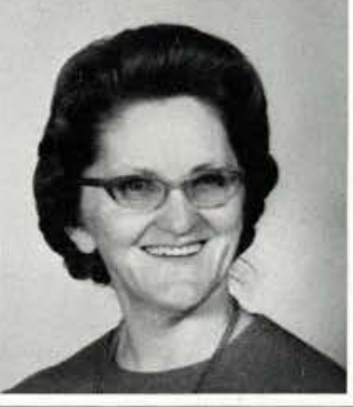

Lois Worley
Business Office

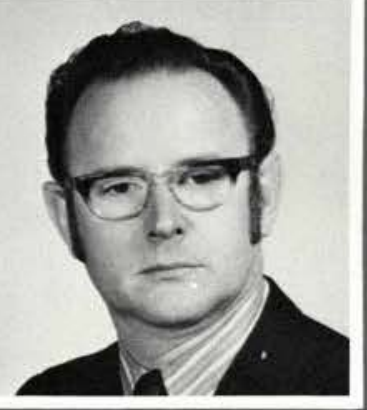

Mr. L. Daryle Worley Music Dept. 


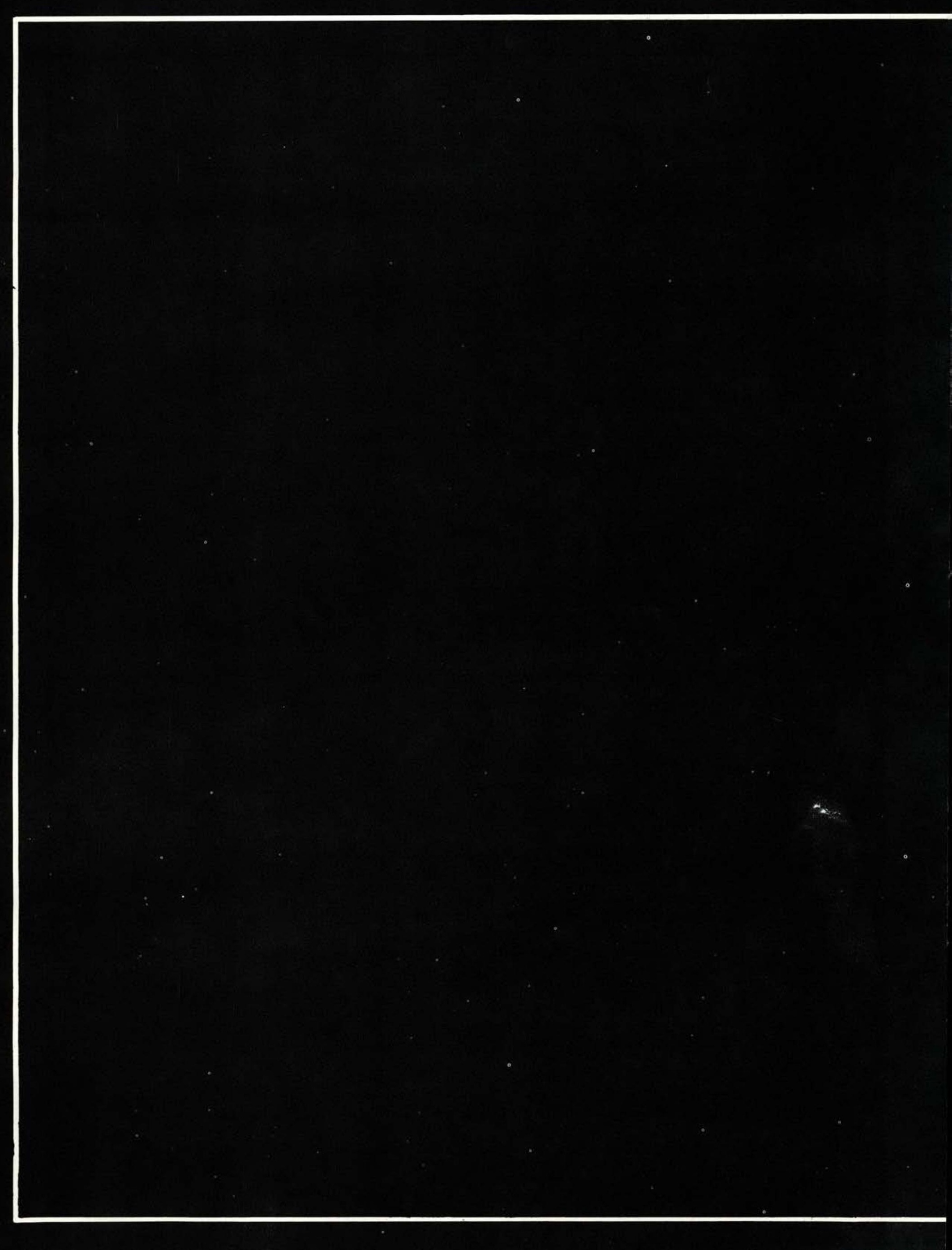









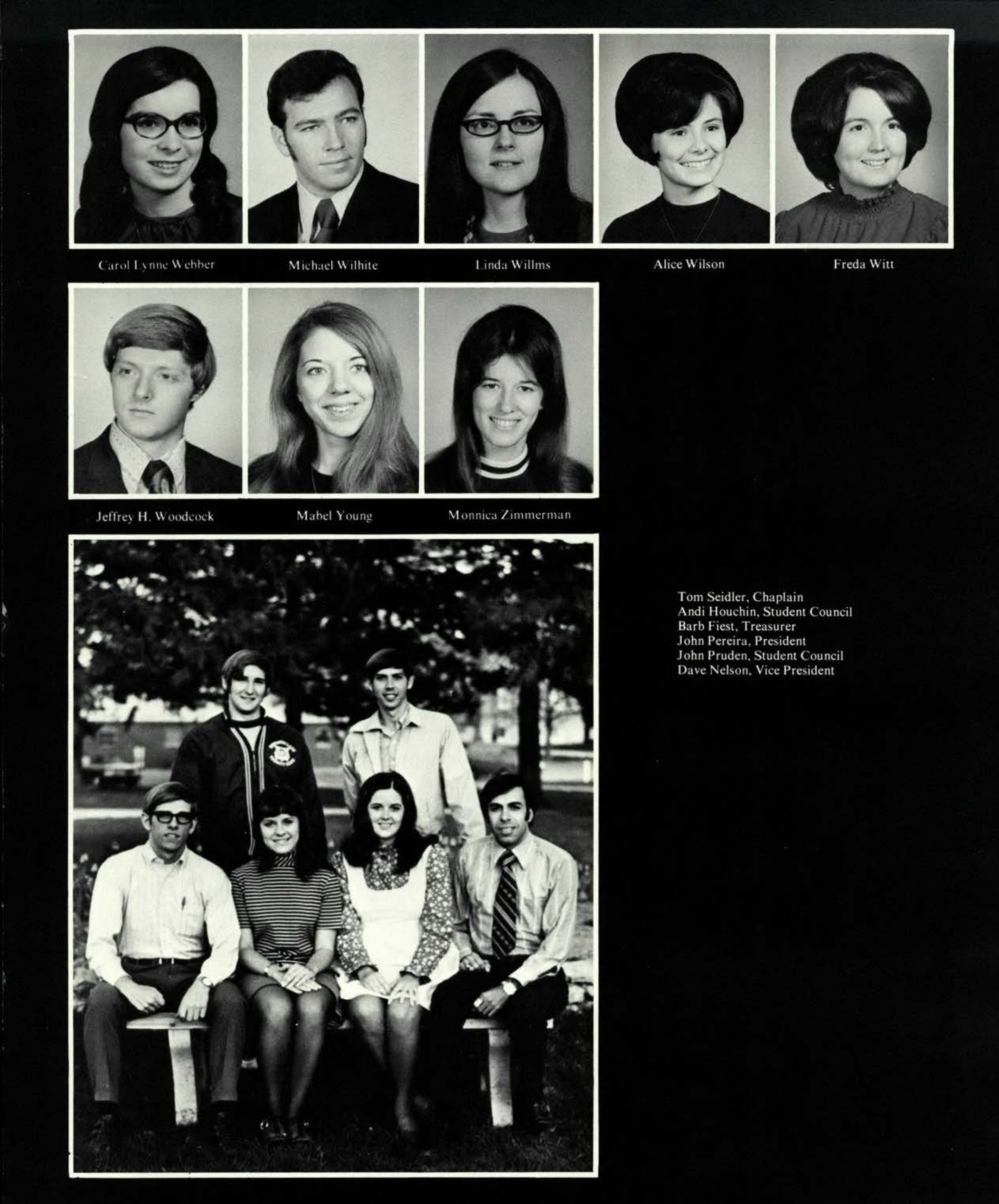




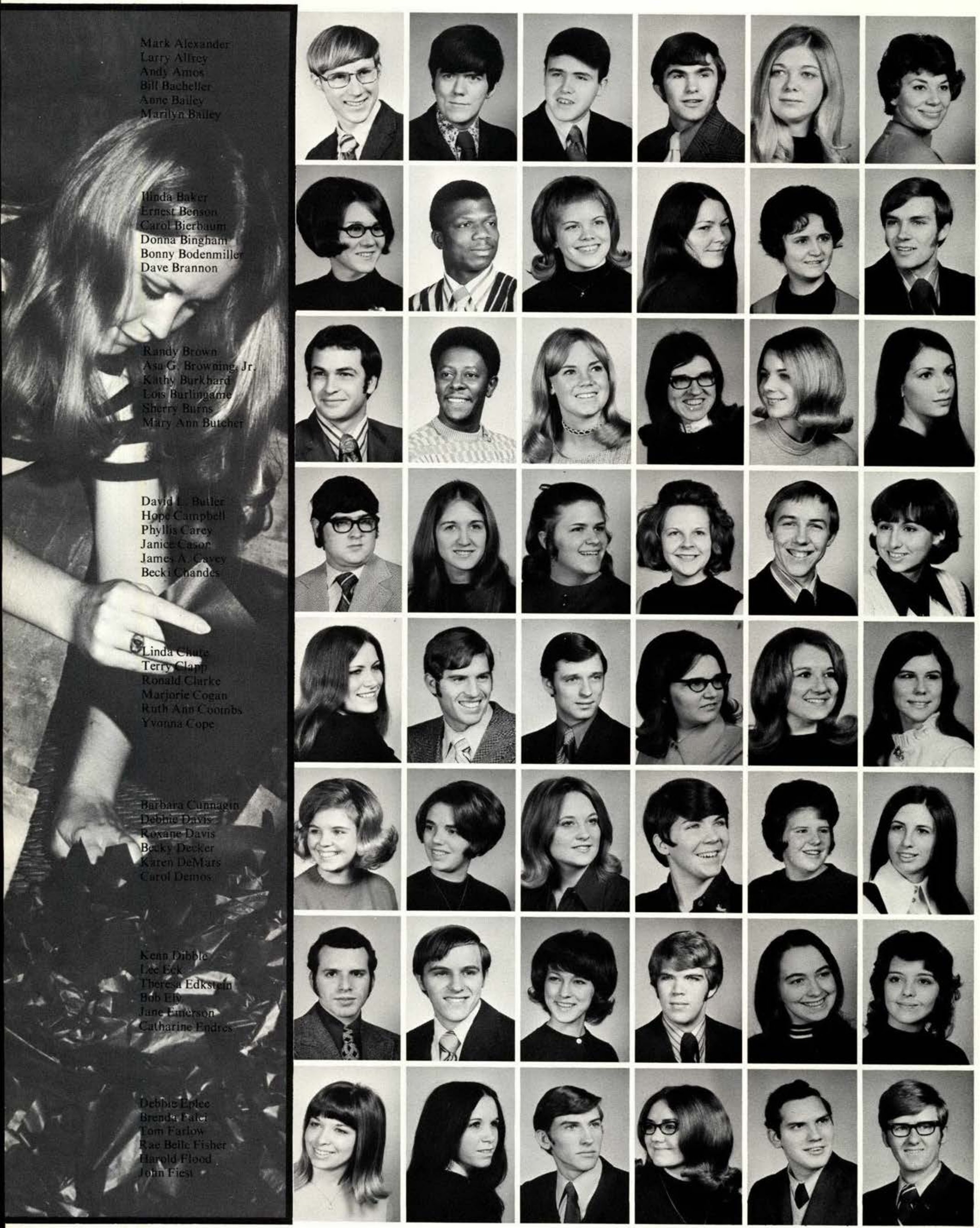



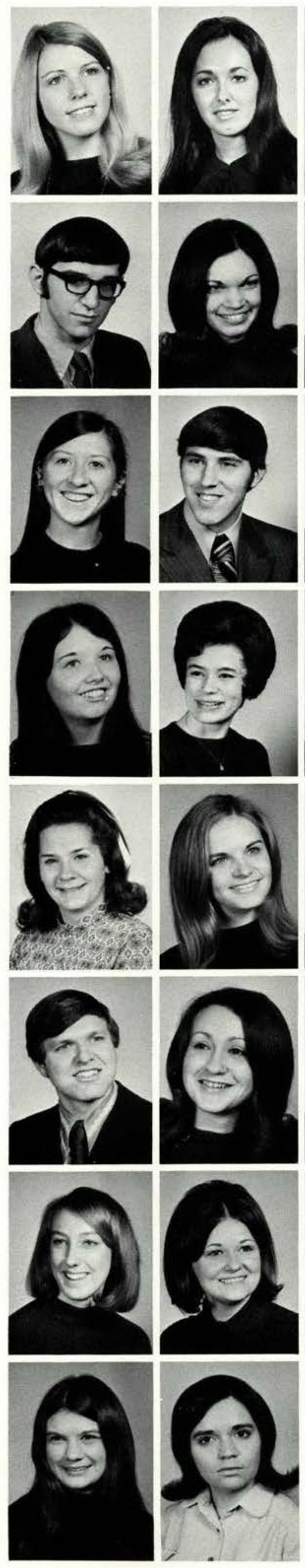
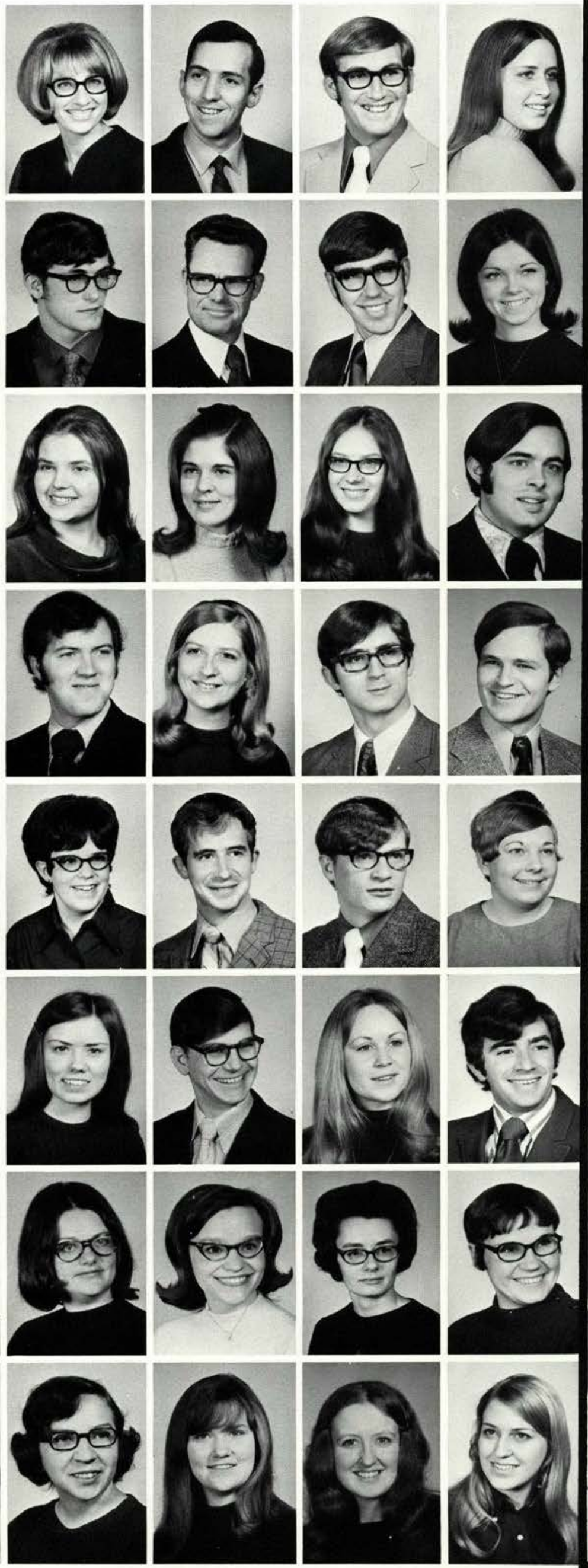

Connie Galbraith

Rita Gast

Donald Gates

Ed Gibbons

Beth Gildon

Kim Gerber

Sharon Gillogly

Louis E. Godby

Jim Goodwin
Leslie Ann Good

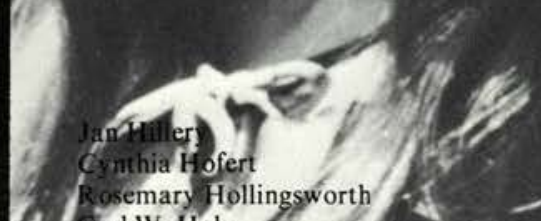

2. Rasemary Hollingsworth Bernor Horn
Sharon Lynn Hothem
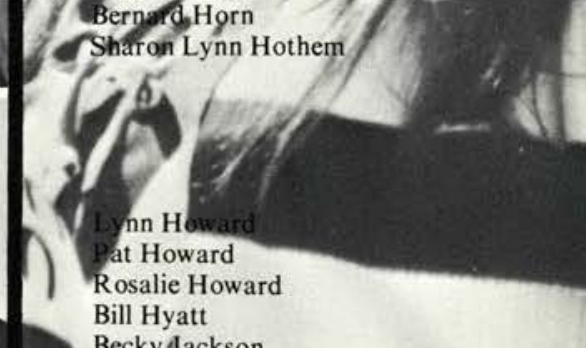

\section{Bill Hyatt}

Jonathan-Jenney

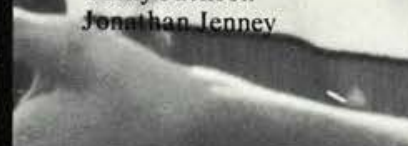

Barbara Johnson

Judy Johnson

Rhea Johnson

Beverly Kemp

Pamela Kendrick

Carol Kies

Lois King 
Lorraine Linderman

Darrell Lowie

Roberta S. Lutton

Connie Mack

Janice Martin

Bonita Ann McNeill

Buddy McNiece

Diane C. Meyers

Yontz Miller

Becki Moore

Beverly Morrow

Thomas H. Mudder

Glennie Murphy

Susan Nauman

Sharon Neeley

Melyin 1. Ne

Bann

m

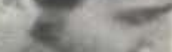

Gene Peterson

Janet Peterson

Becki Poarch

Glenda Porter

Paula Prater

Grace Pruden

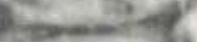

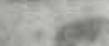

$P_{0.12}$

Connie P

Steve Read

Vicki Reynolds

Galle Richardson

Dennis Roberts

Carl Rodgers

4. Carl Rodgers

David Rodriguez 2 St

Chris Rufener?

Priscilla Russell
Eldon Saryer

Marion Scharmann

Esther Schultz

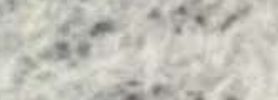

Steve Shank

Linda Shorey

Mark J. Sloan

Adria Soeder

Bonnie Spears

Stephen W. Spink

Janice Spradlin

Karen Stevenson

Sharon Stevenson

Linda Suter

Karen Syphers

Dan Thompson
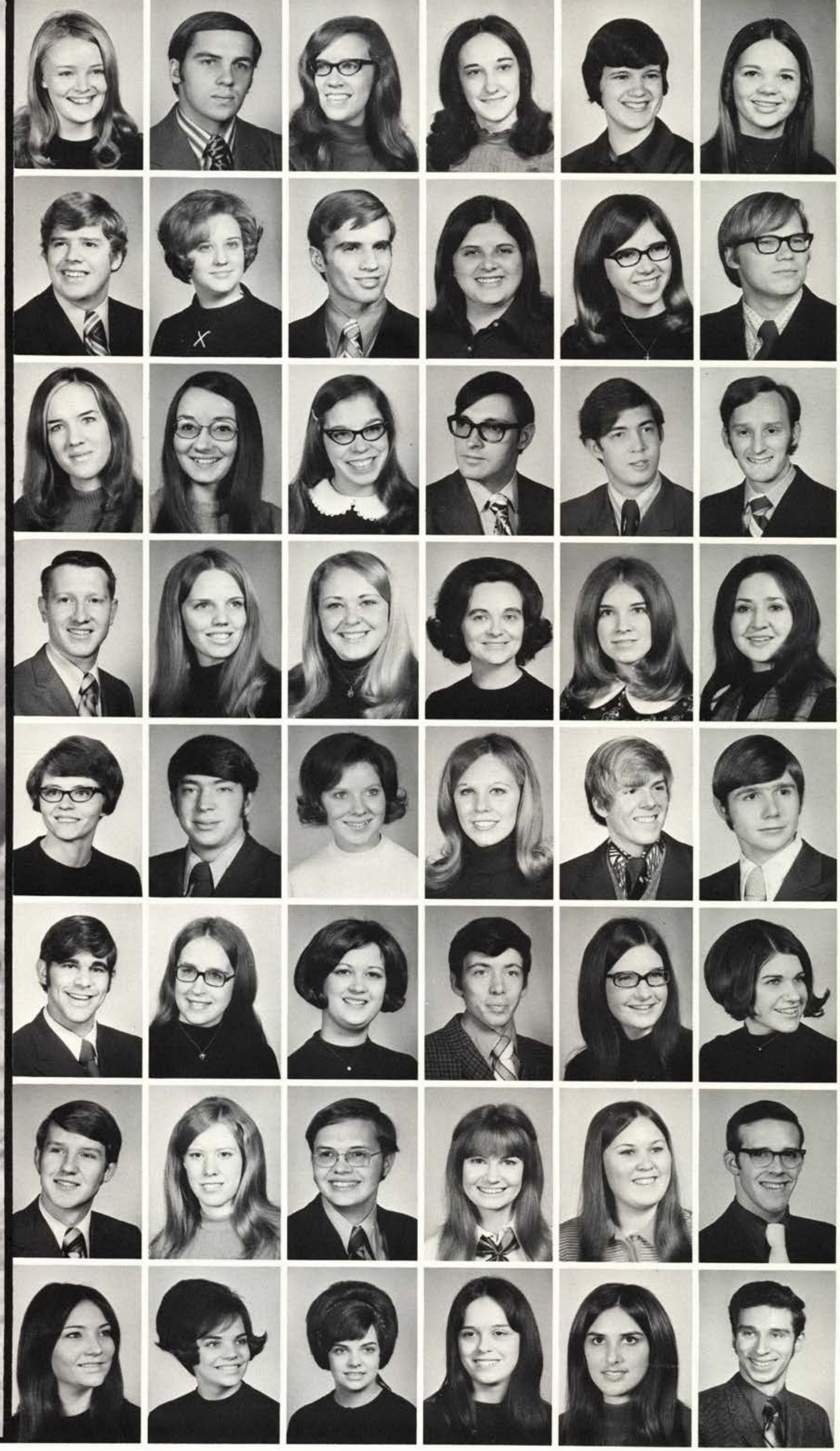

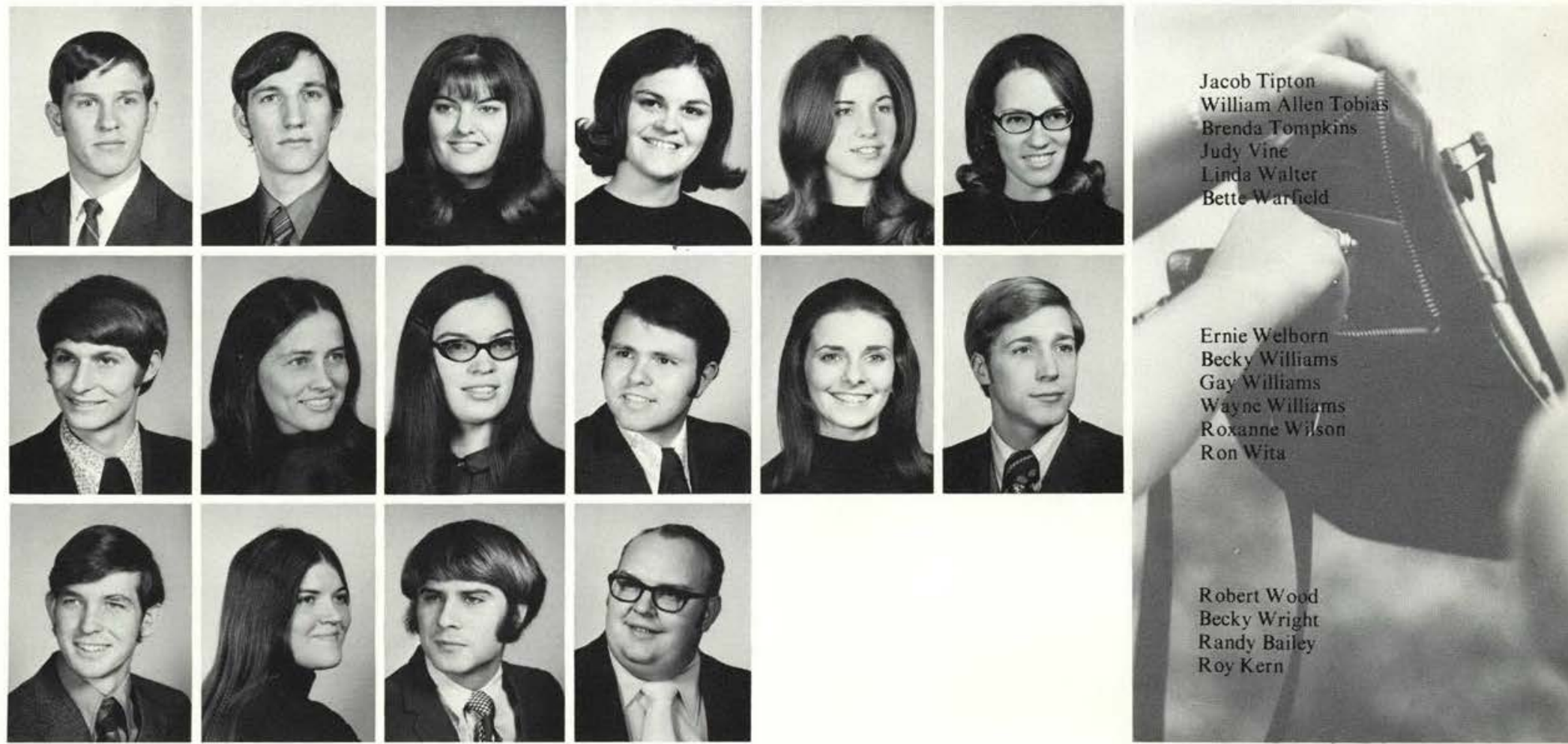

Robert Wood

Becky Wright

Randy Bailey

Roy Kern

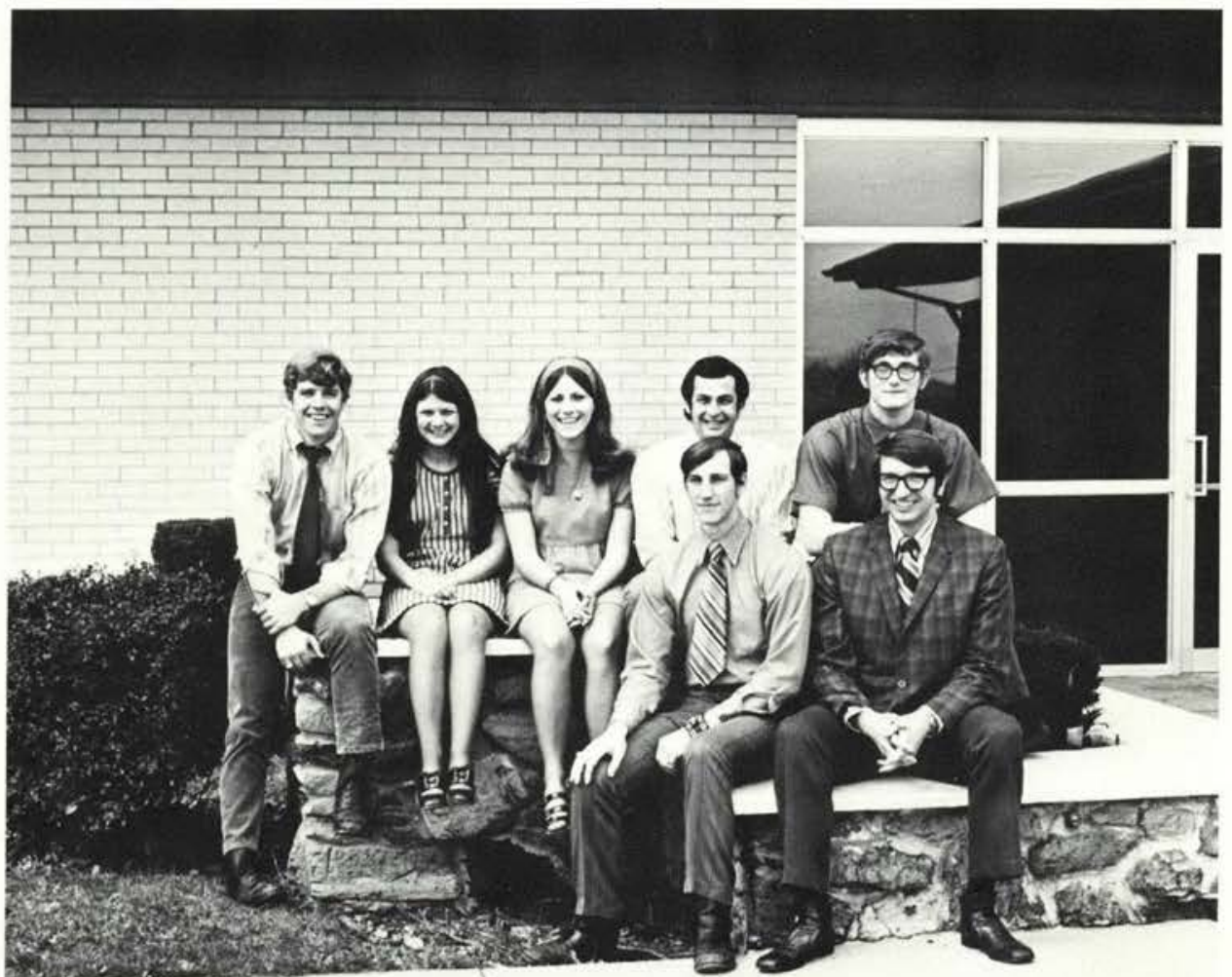

Buddy McNiece, President

Bev Kemp, Treasurer

Linda Chute, Student Council

Randy Brown, Vice President

Dave Globig, Student Council

Bill Tobias, Chaplain

Mr. Wilcoxon, Advisor 
Daniel Adamowich

Clay Abertson

Becky Anderson

Diana Adkins

Robert Andrew

Dinah Arthur

Siepnen Assey

Timothy N Barke

Sharon Bartemus

Jeb Beachum

rien

Villiam BeauJean

Ronald J. Bechtel

Kelsey Bennet

Dan Bergen

Barb Bigg

Dan Boger

Edythe Carity Kenneth W. Carlton Bertha L. Carter Randy Clark Nancy Cleckner Jackie Cline

Andrew Cole David Cot noi Beth Cooley

Diane Craig Sherill Cress Eric Cueni

\section{Debbie Durham}

Dana Dillon
Vivian Dials Joyce DeBruine Beverly Davison Debbie Dear
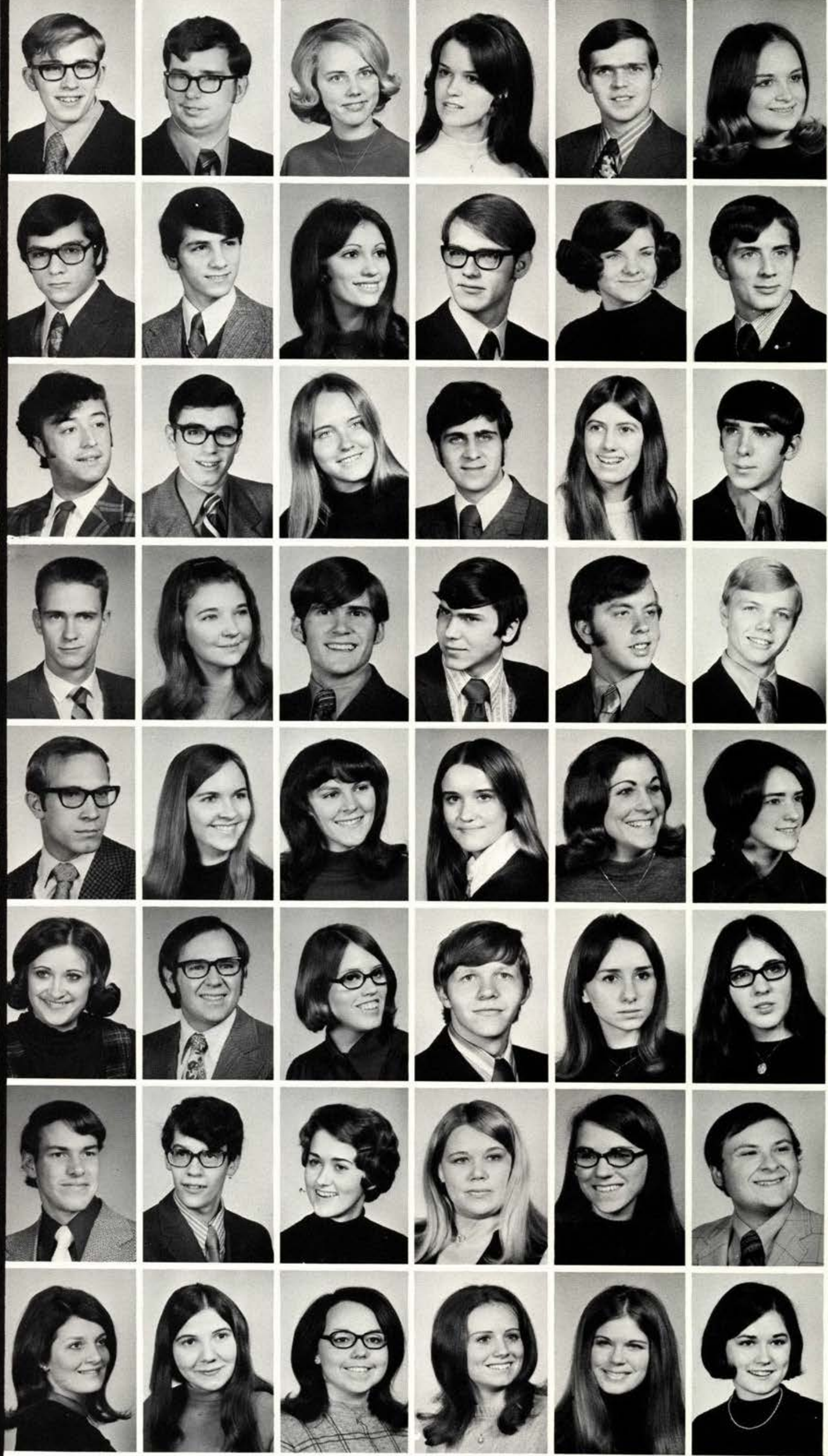


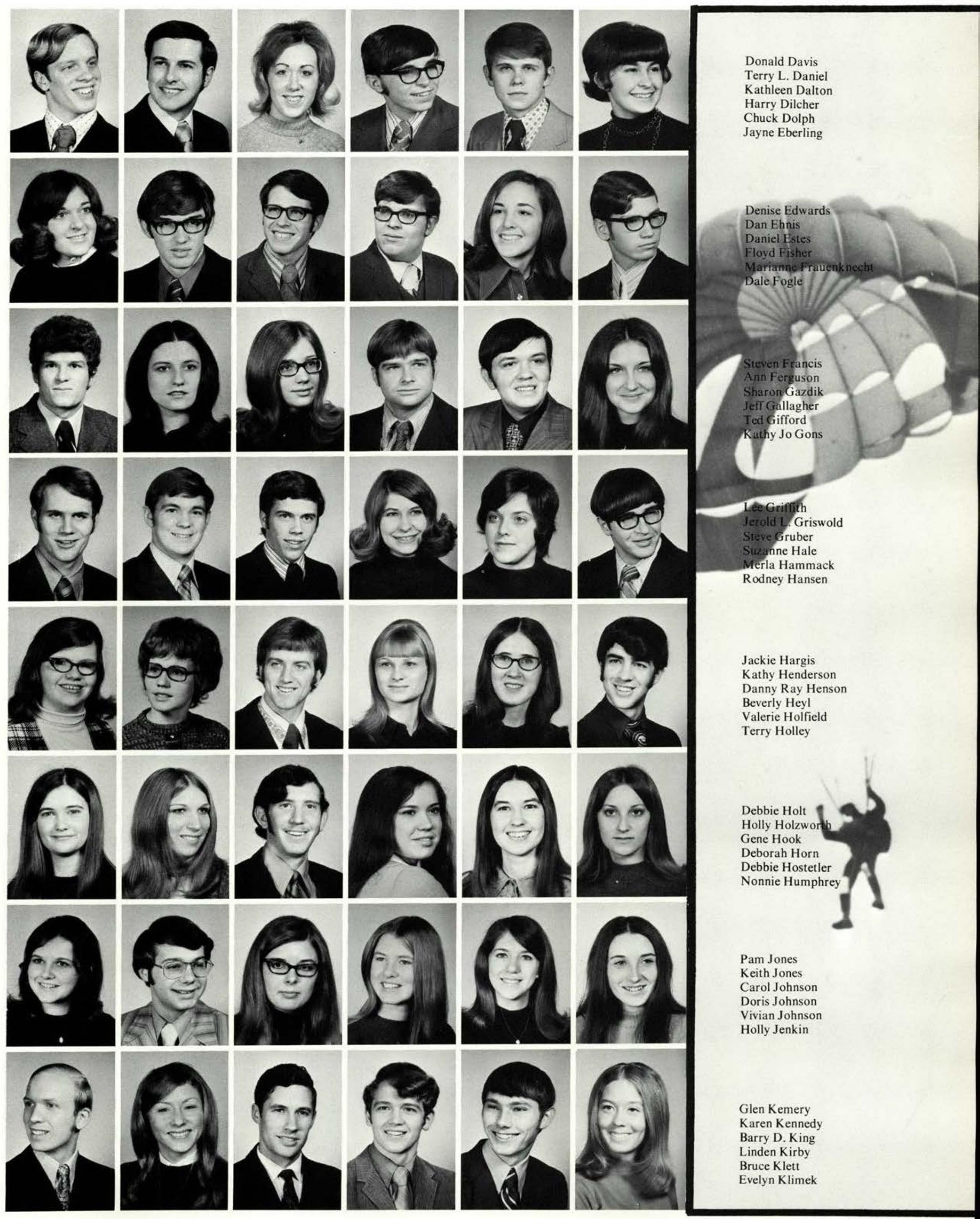




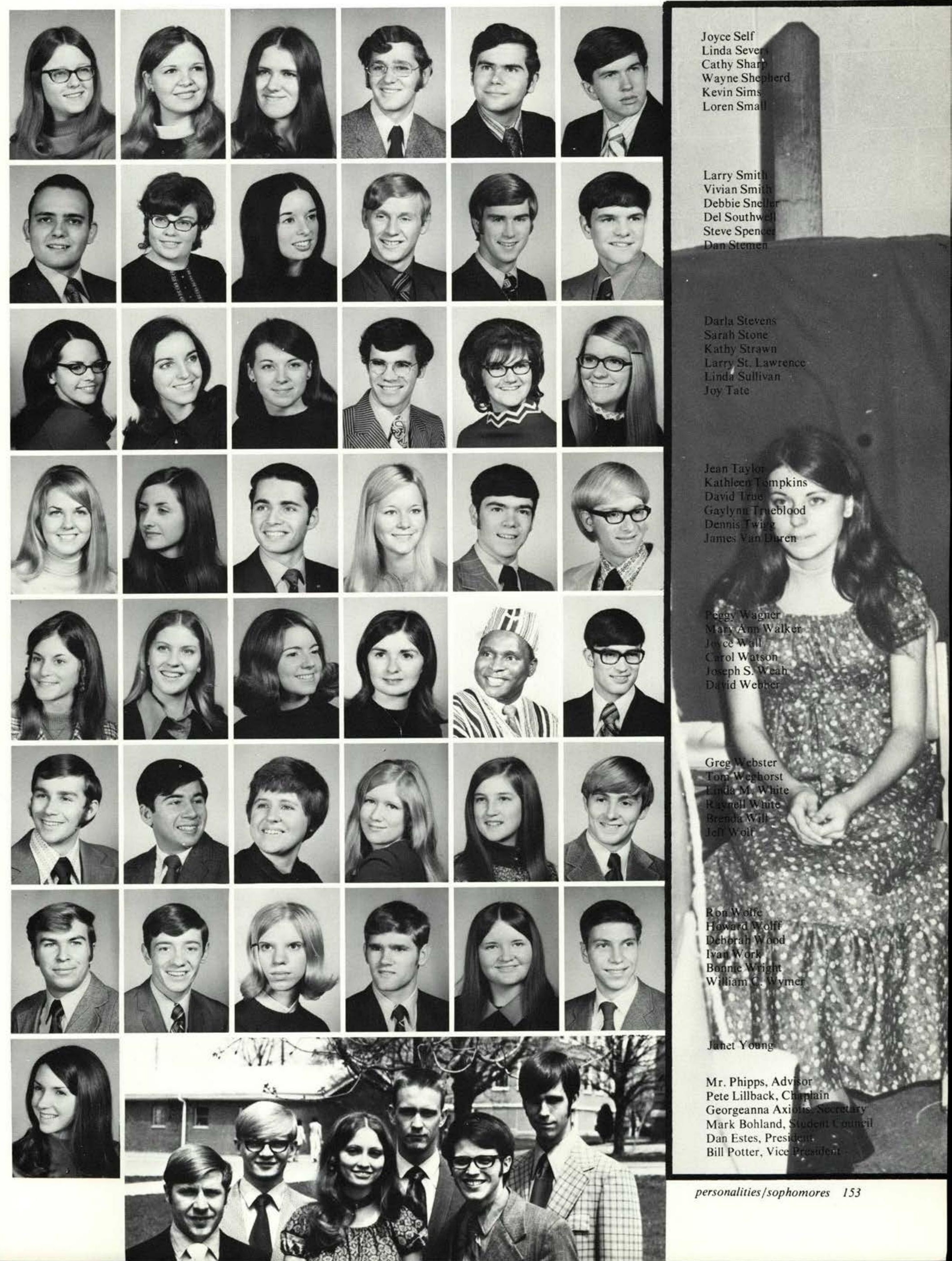


Wayne Aldridge

Paul Allen

Carol Lynn Anderson

Debbie Banks

John M. Battaglia

Doug Bauder
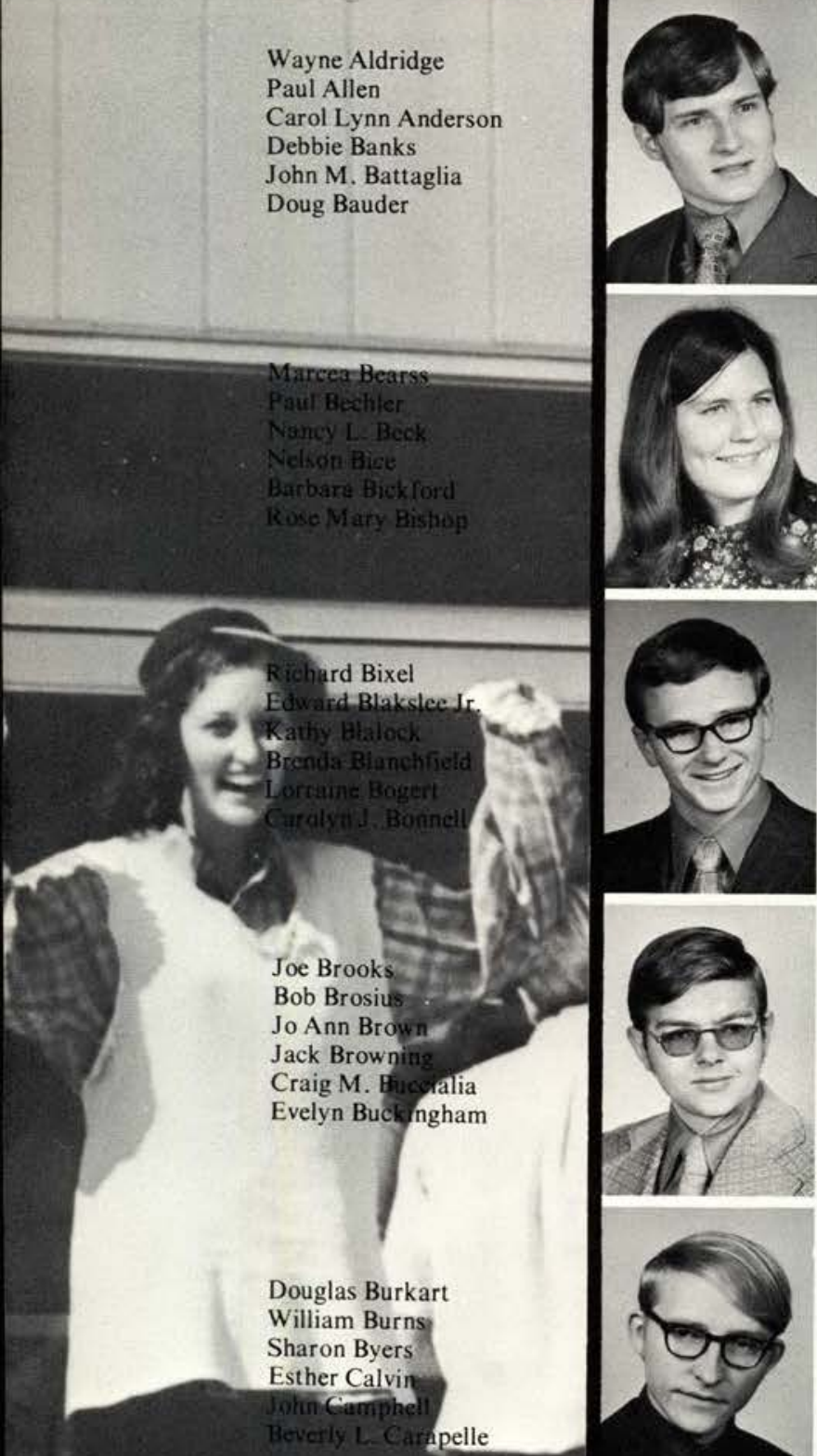

$2=$
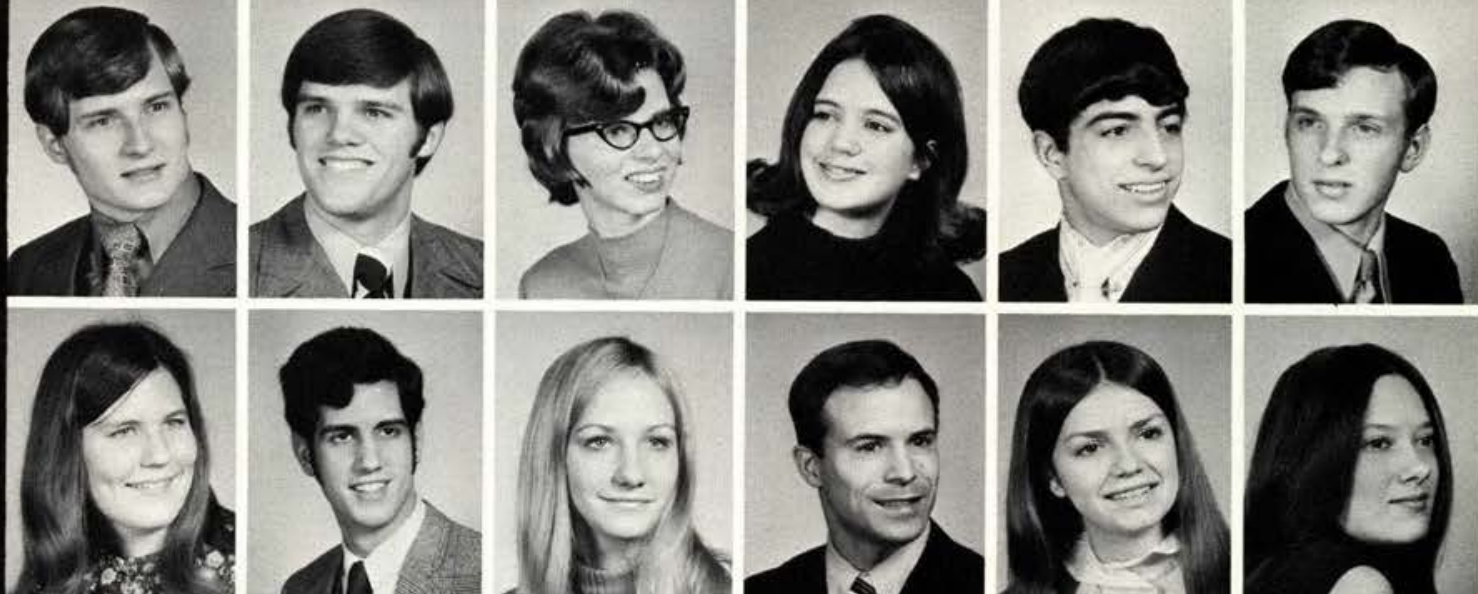

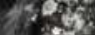
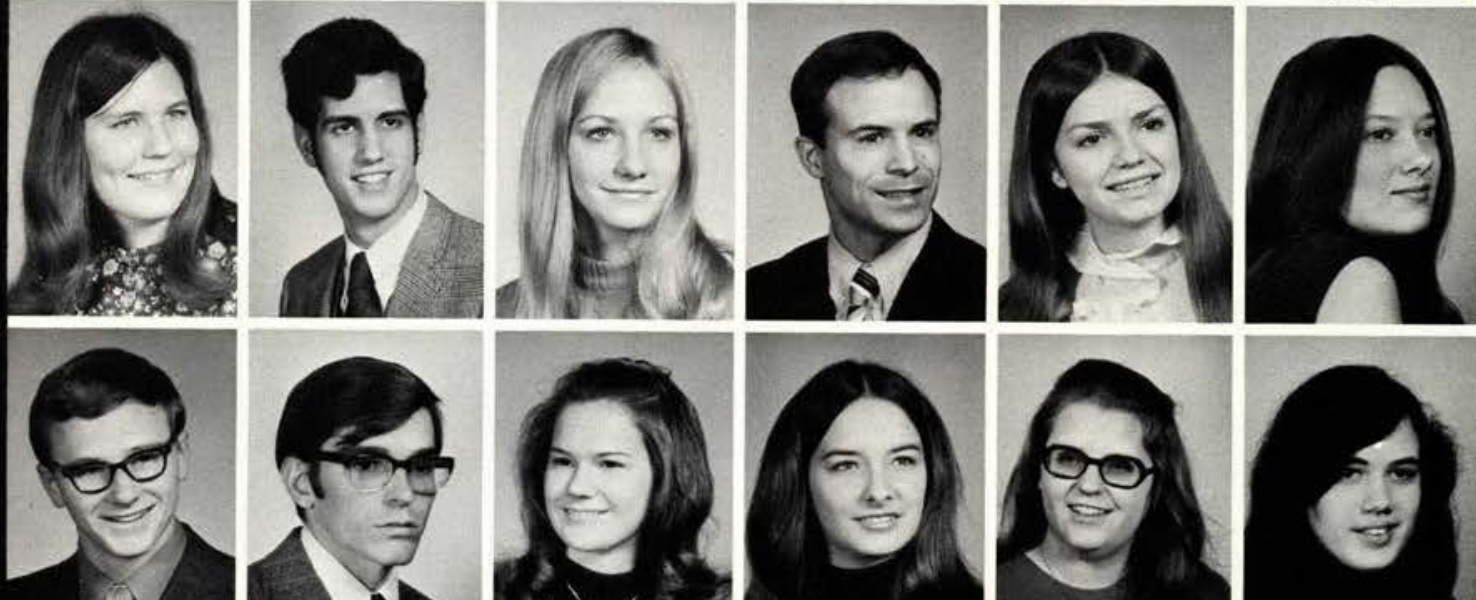

$\underbrace{-\frac{R}{k_{i}}}$
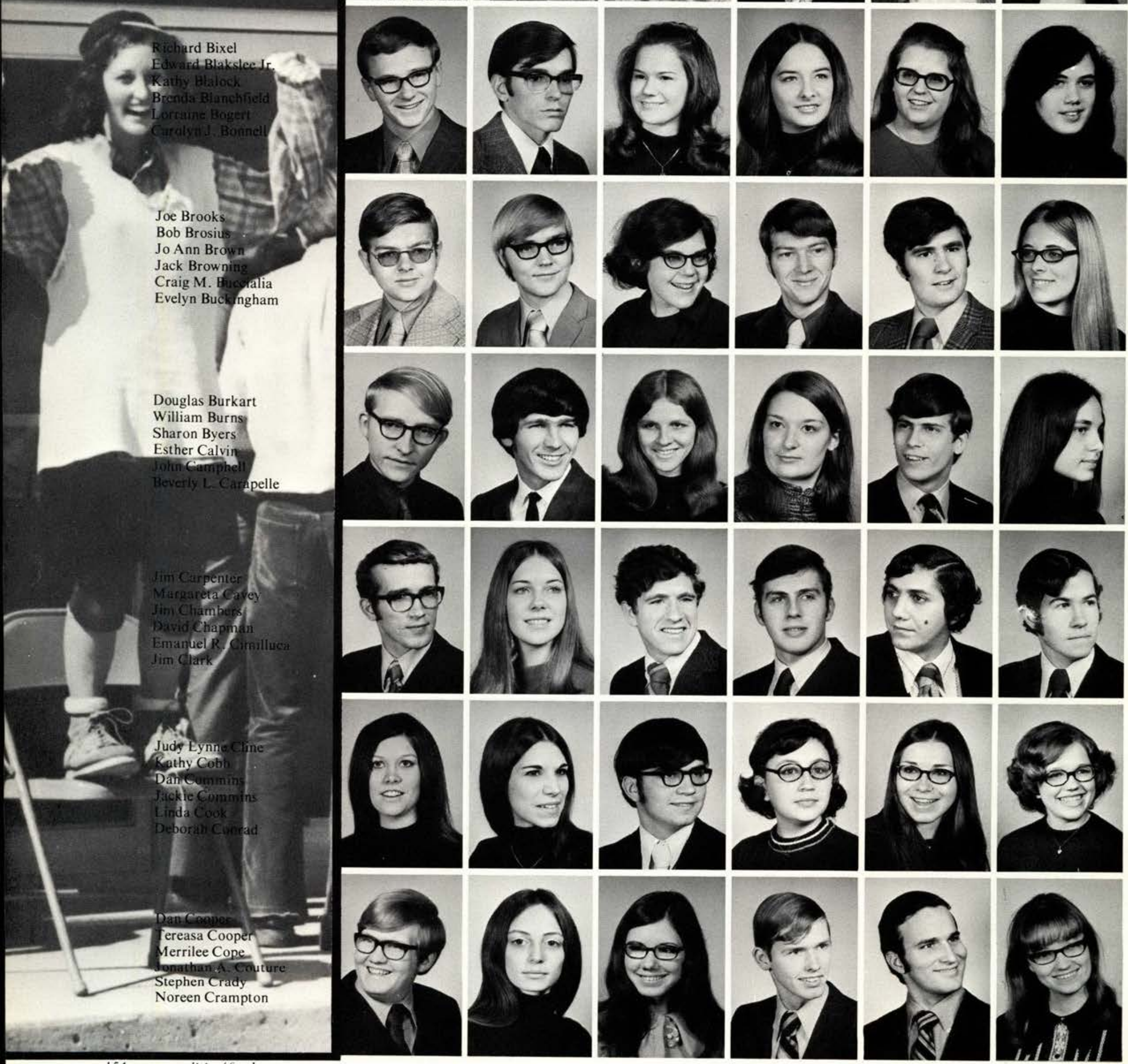

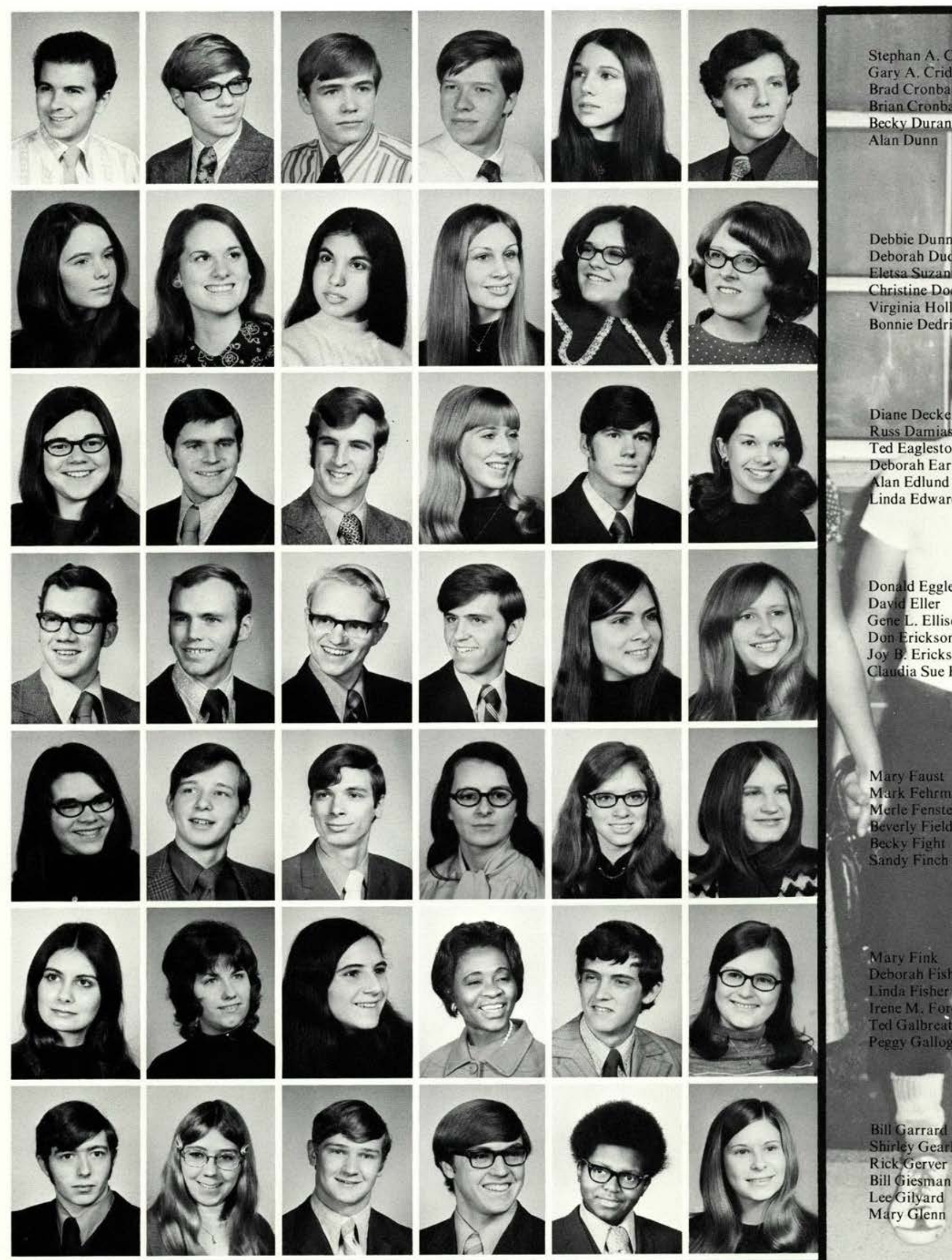

Donald Eggleston

Dayid Eller

Gene L. Ellison

Don Erickson

Joy B. Erickson

Claudia Sue Farmer
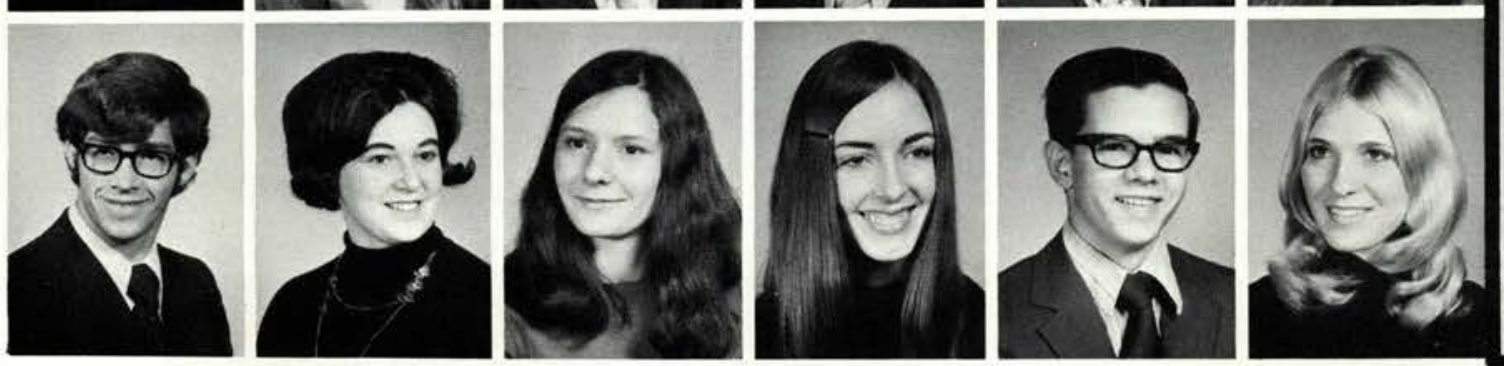

W. Scott Gons

Pat Gordon

Florence Ann Good

Tim Grabianowsk

Mindy L. Graf 


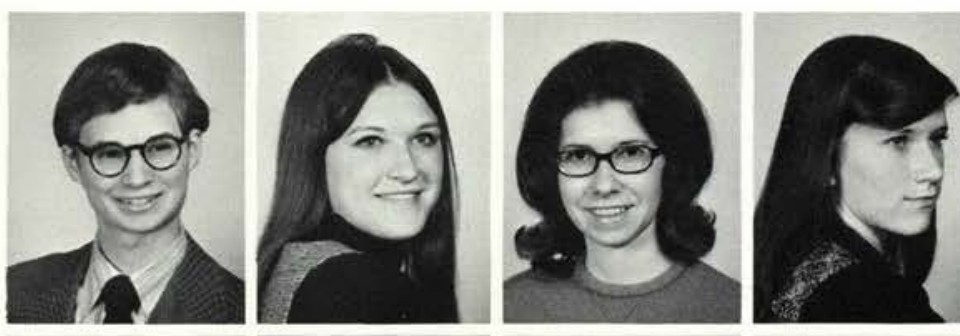

(2)
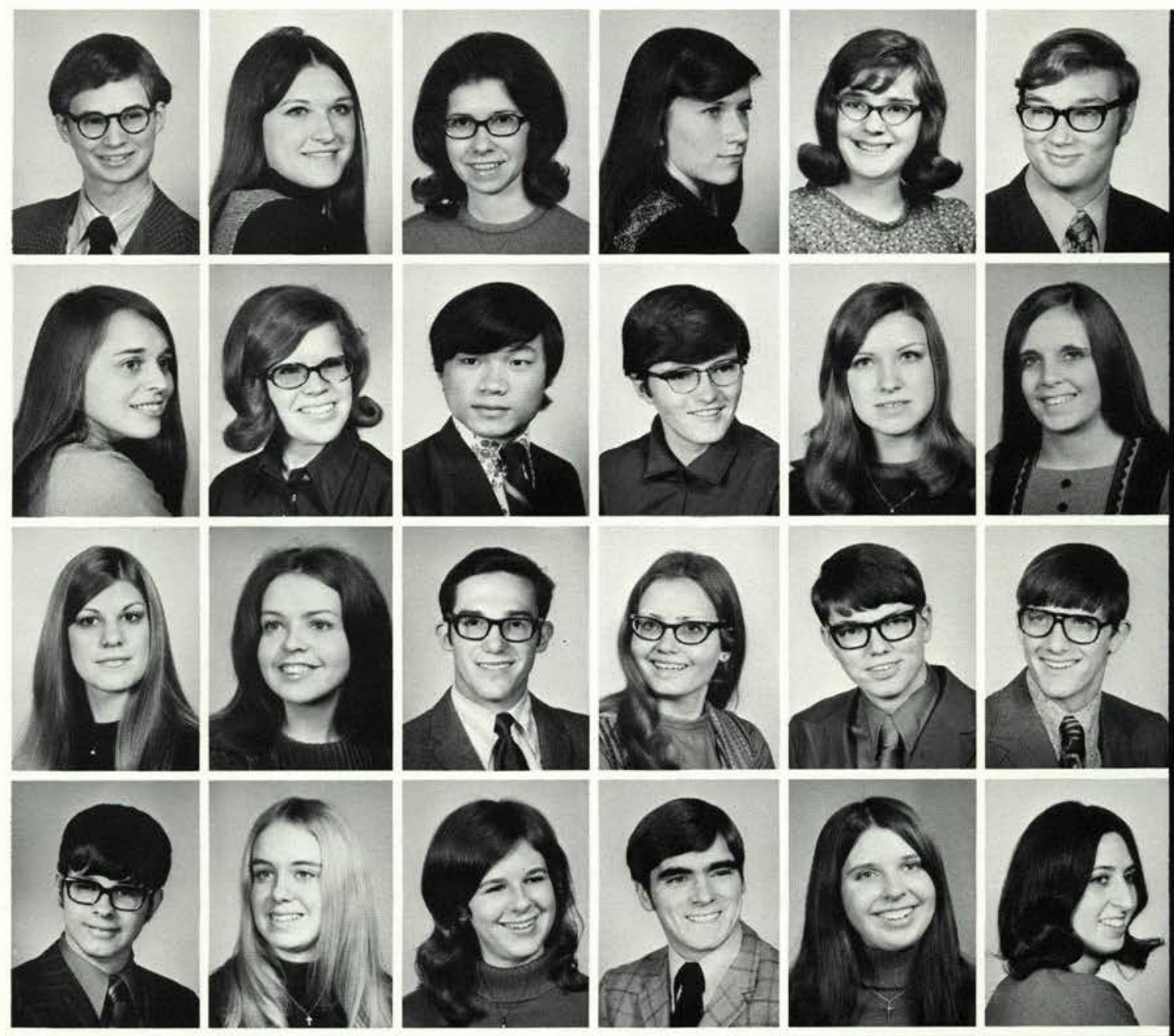

(2) F्रु
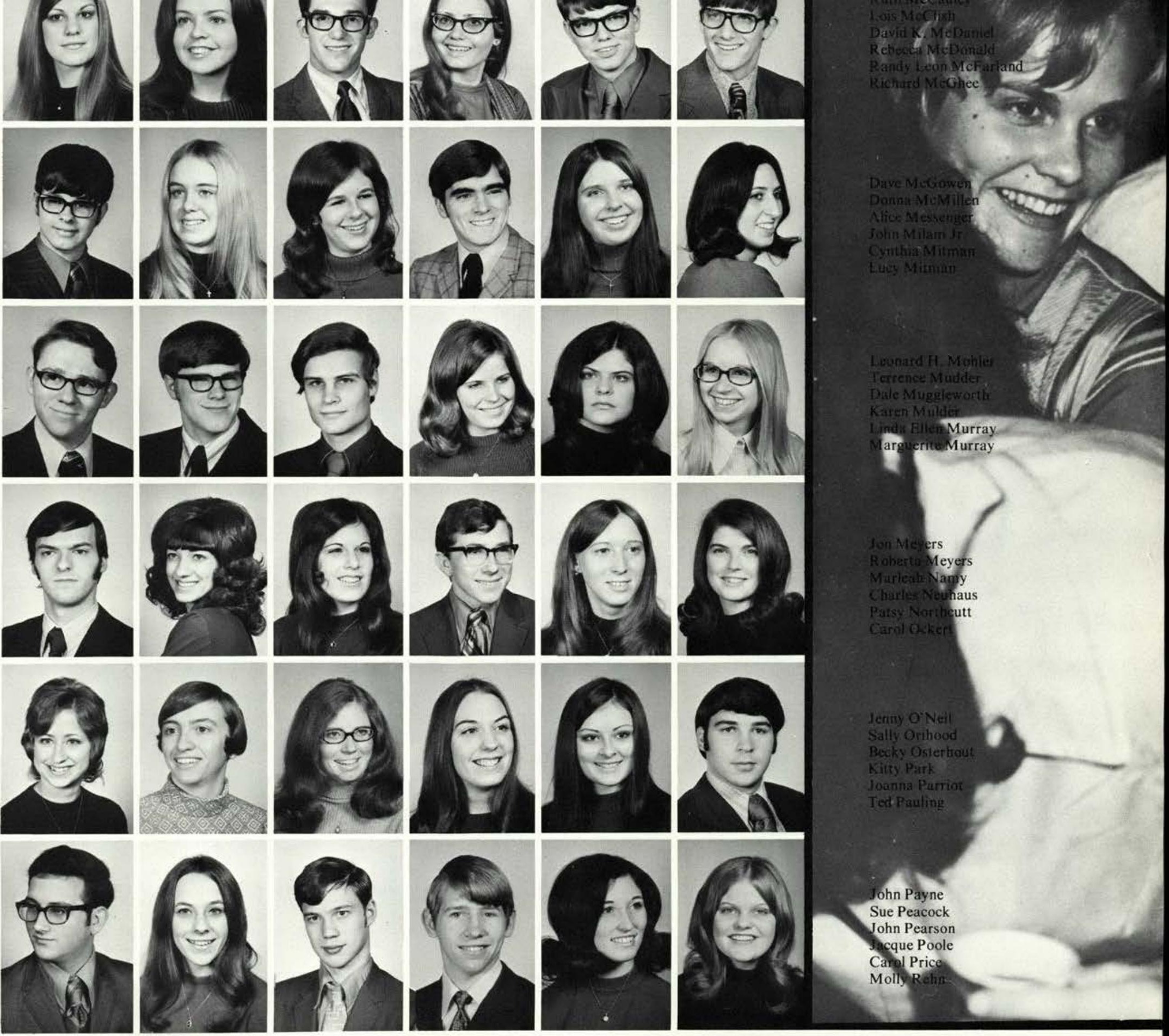


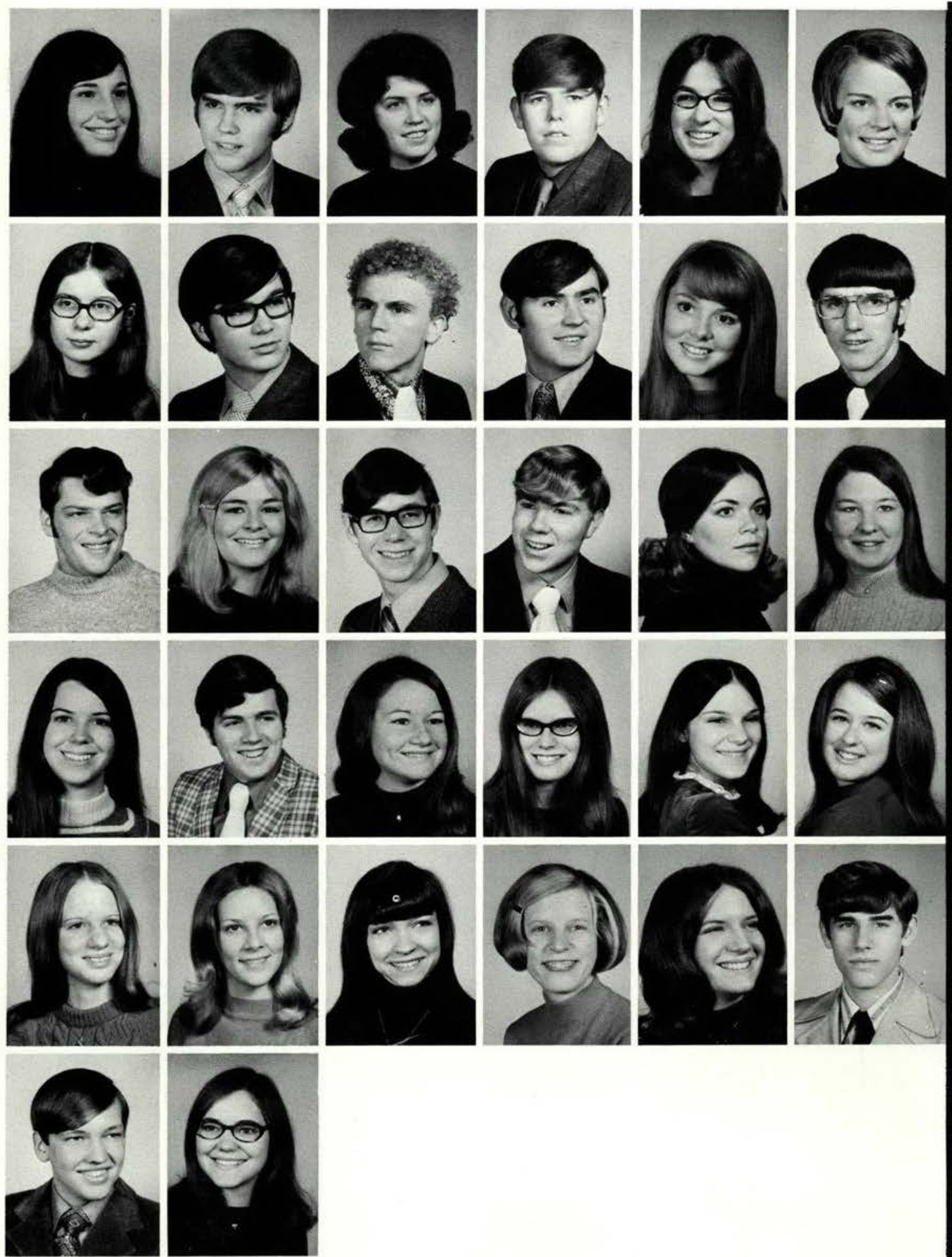

David Van Dorf

Cody Vincent

Jo Vincent -

Becki Wallner

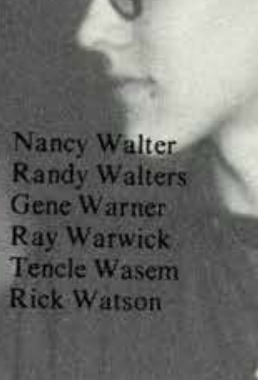

Gary Weaver

Linda Wellmeier

Bruce Widicka

Paul Wigand

Wendy White

Cynthia Wiggins

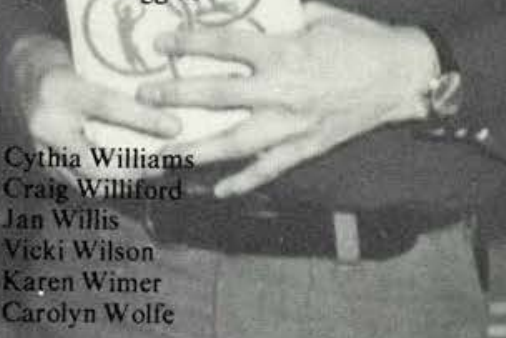

Myron Youngman

Linda Lynn Y

Karen Young

Stephien Young

\section{Beverly Ziegler}

Ziegler

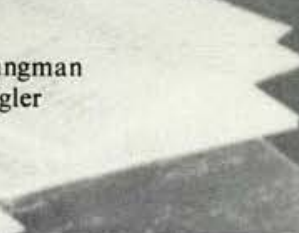

Don Johnson, Vice President

Doug Schroeder, Chaplain

Debbie Jones, Treasurer

Debbie Dudley, Secretary

Paul Allen, Student Council

Craig Williford, President 
Randy Caldwell

Mickey Duerler

Earl Filson

Bob Fowle

Paul Francisco
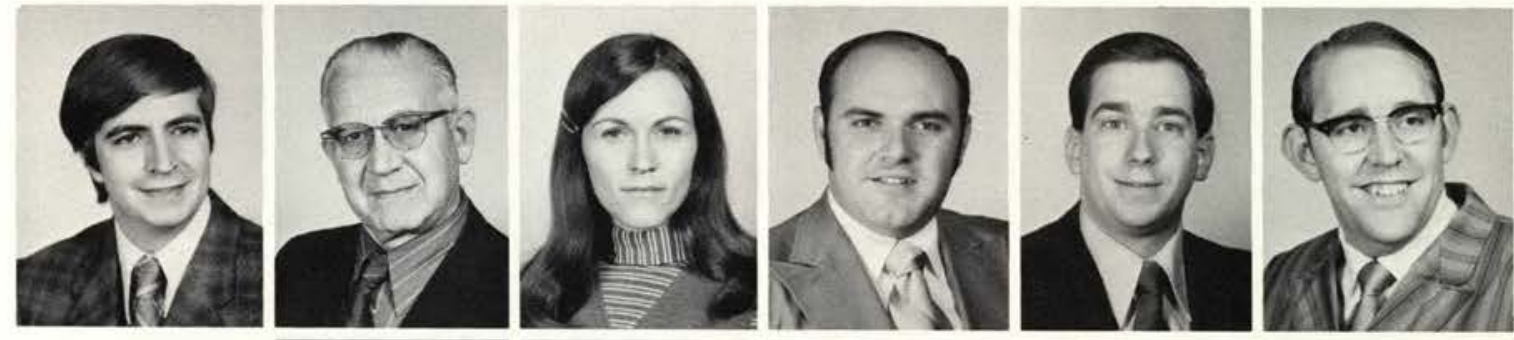

Margaret Green

Bonnie Nolen

Paulette Payne

Cindy Rentas
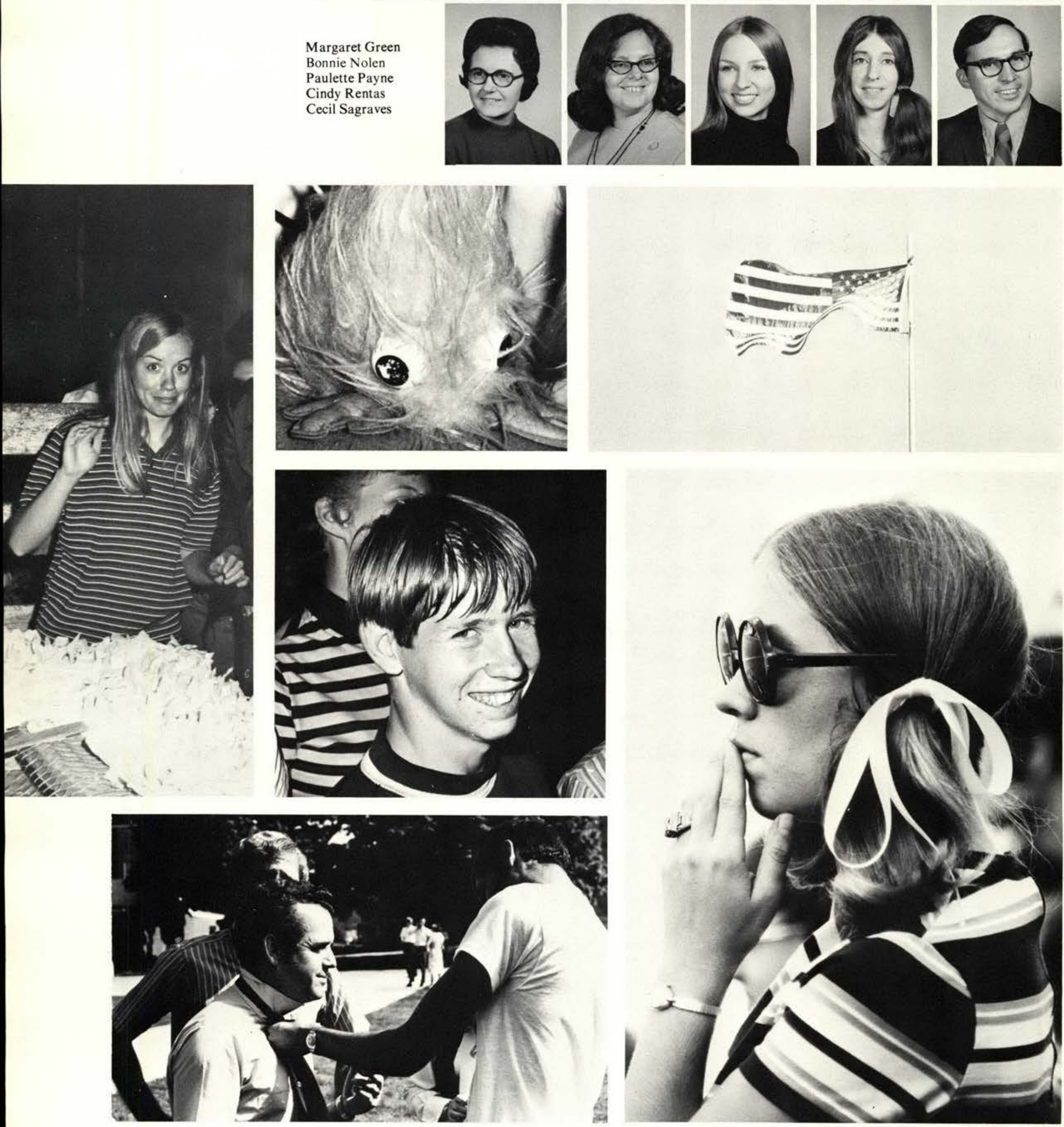

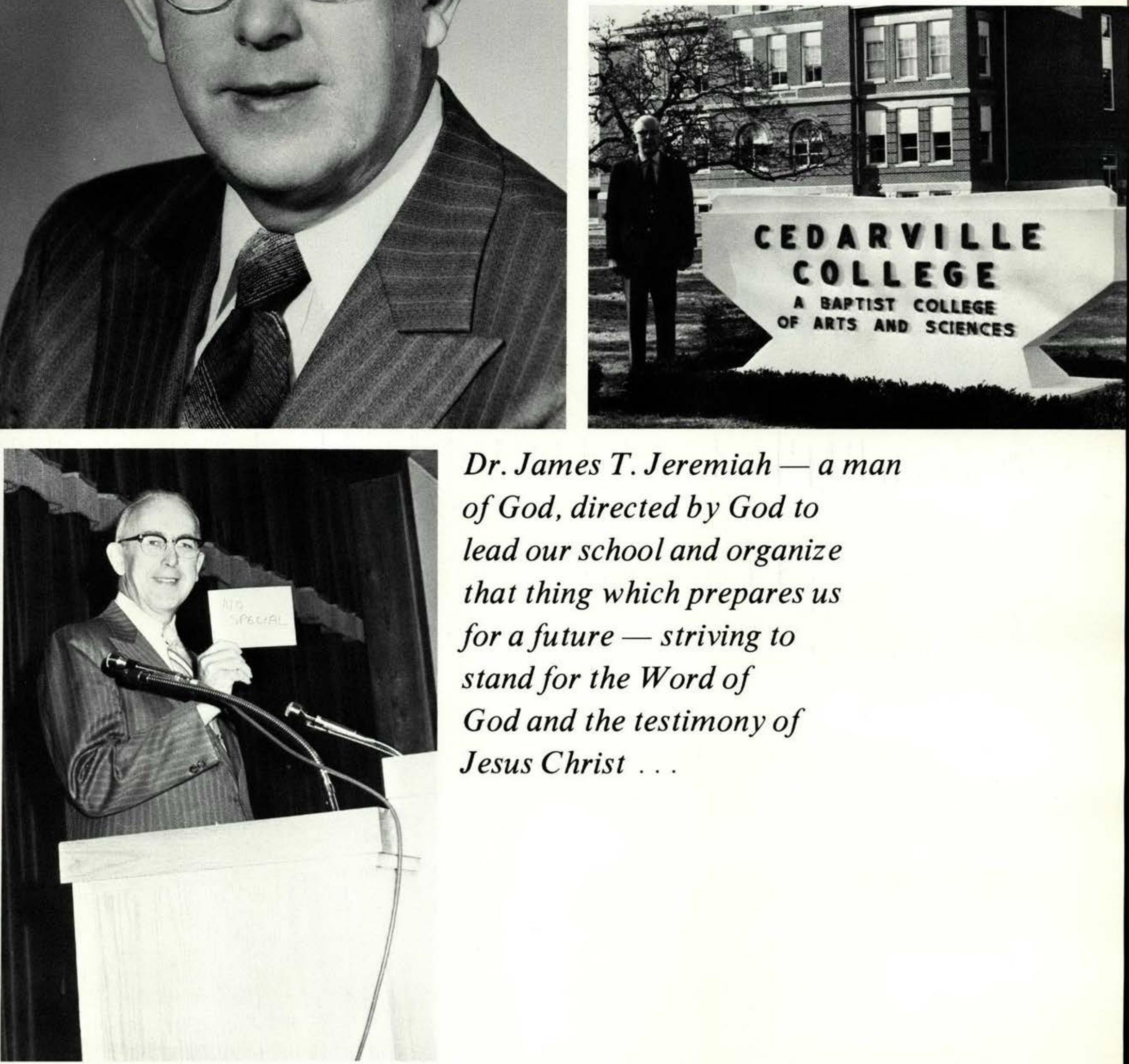

Dr. James T. Jeremiah - a man

of God, directed by God to

lead our school and organize

that thing which prepares us

for a future - striving to

stand for the Word of

God and the testimony of

Jesus Christ . . . 


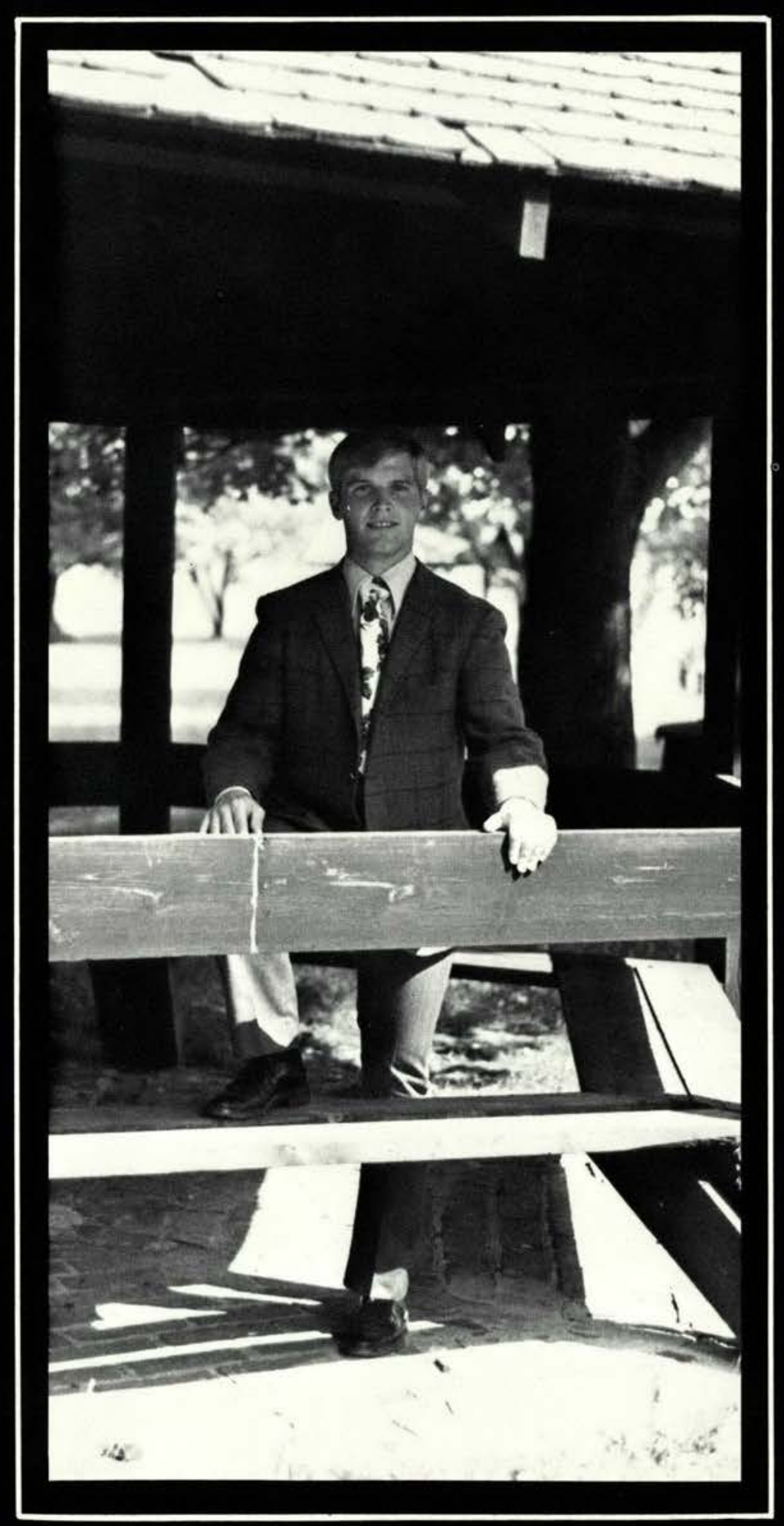

Lyle Miller

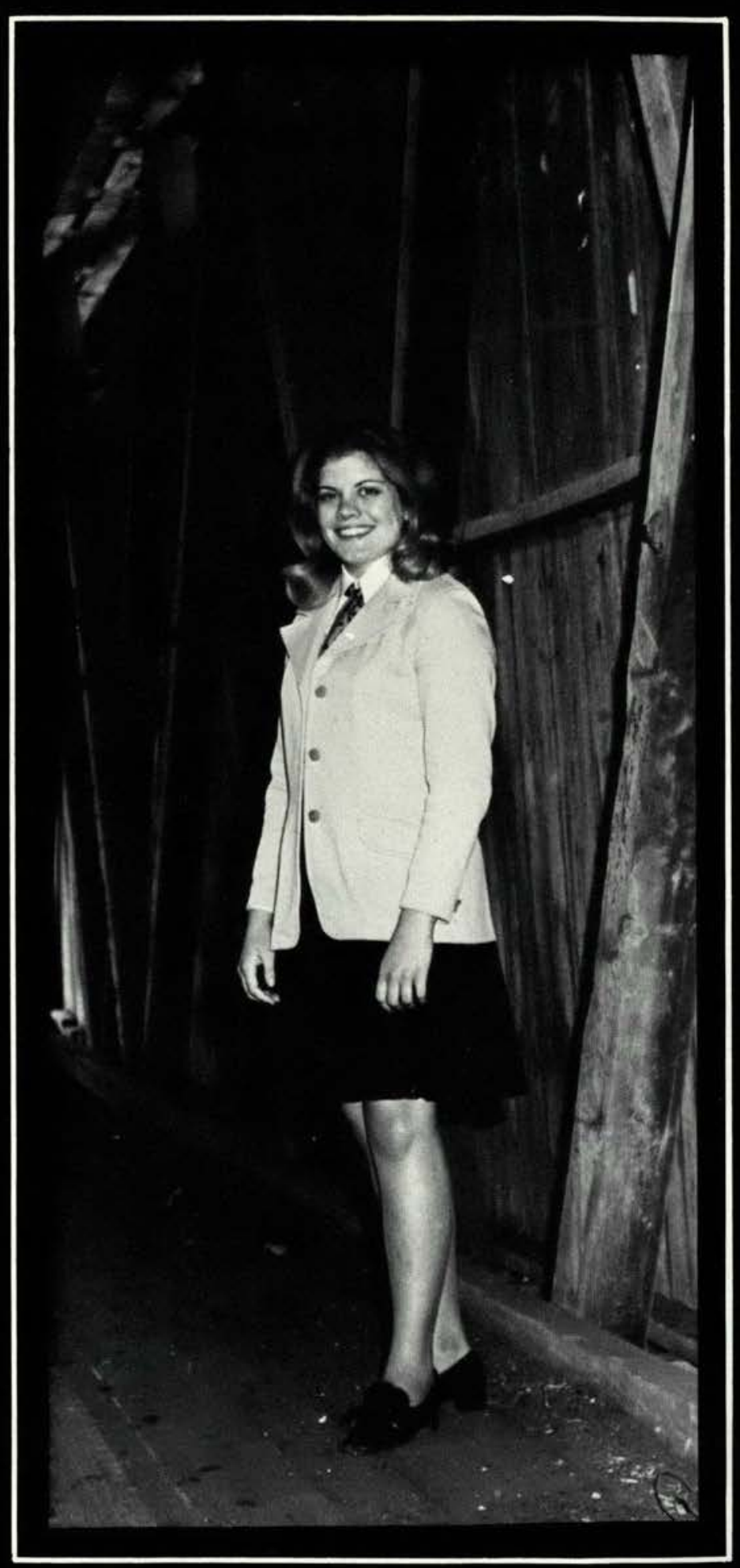

Carol Bierbaum 


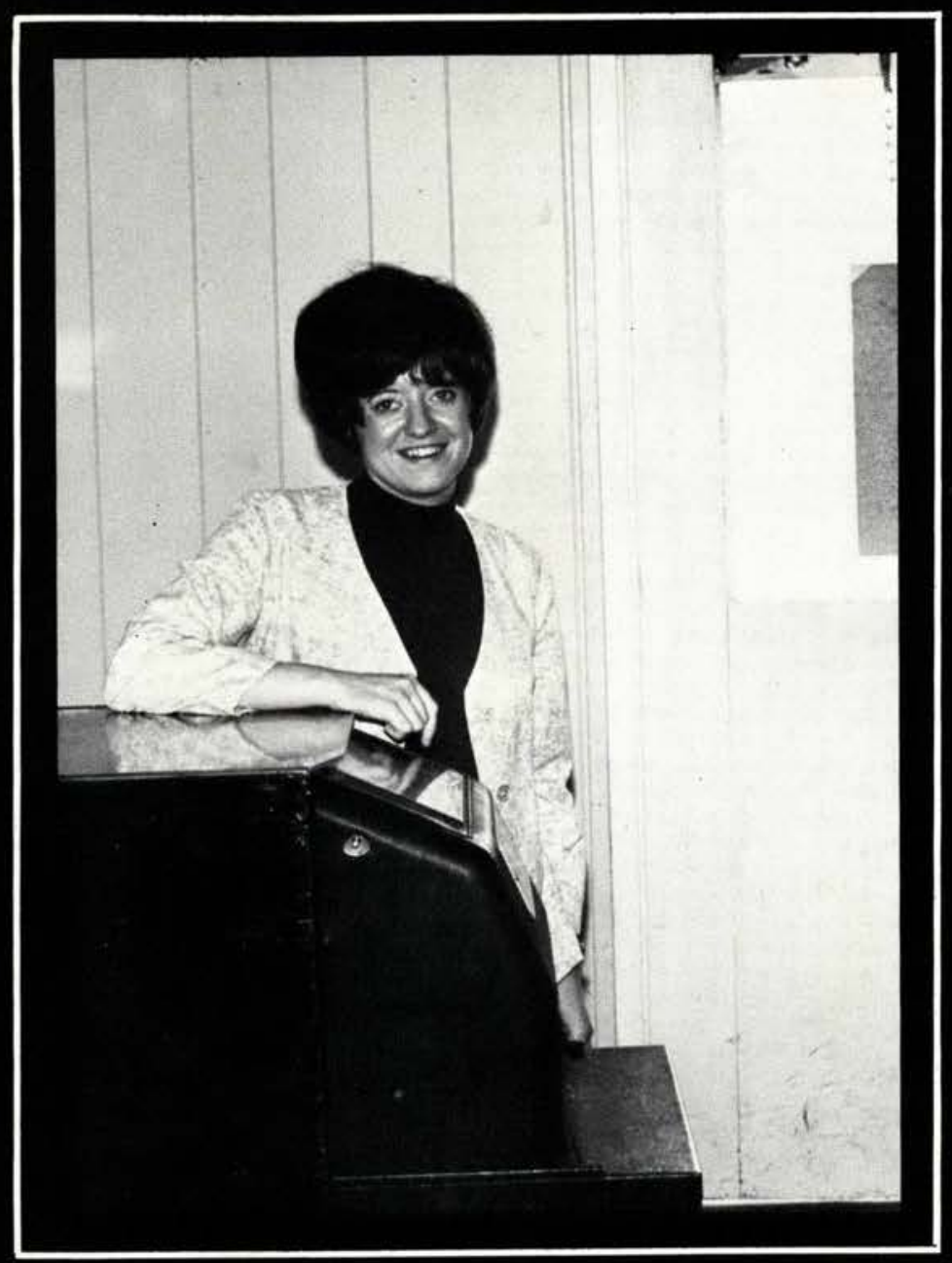

Fran Chambers
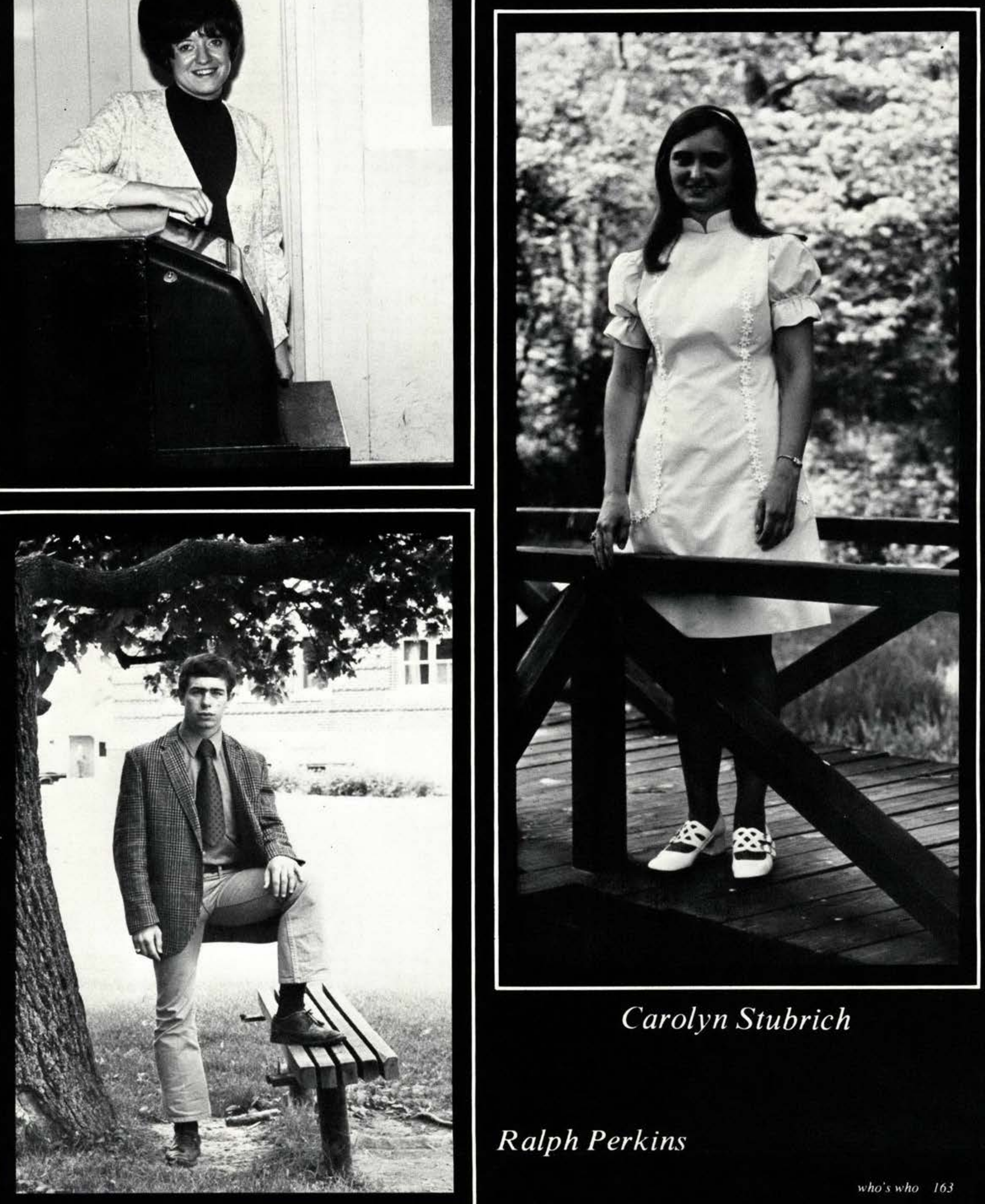

Carolyn Stubrich

Ralph Perkins 


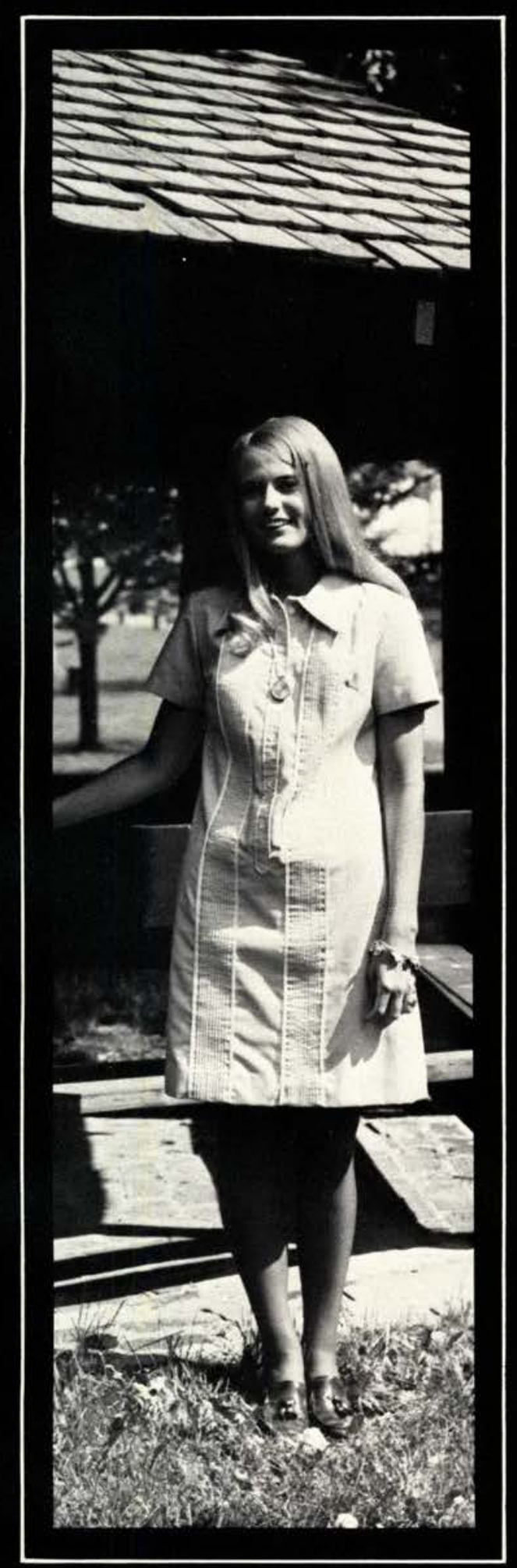

Meda Sue Edelblute

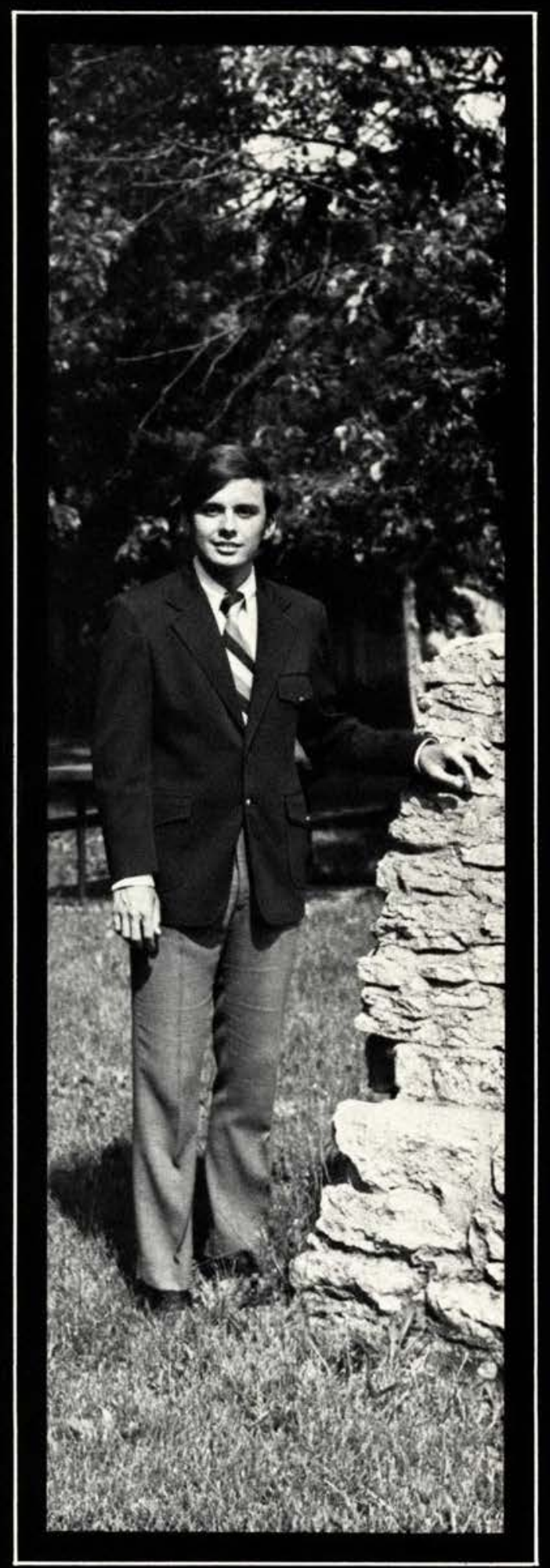

Dave Jewell

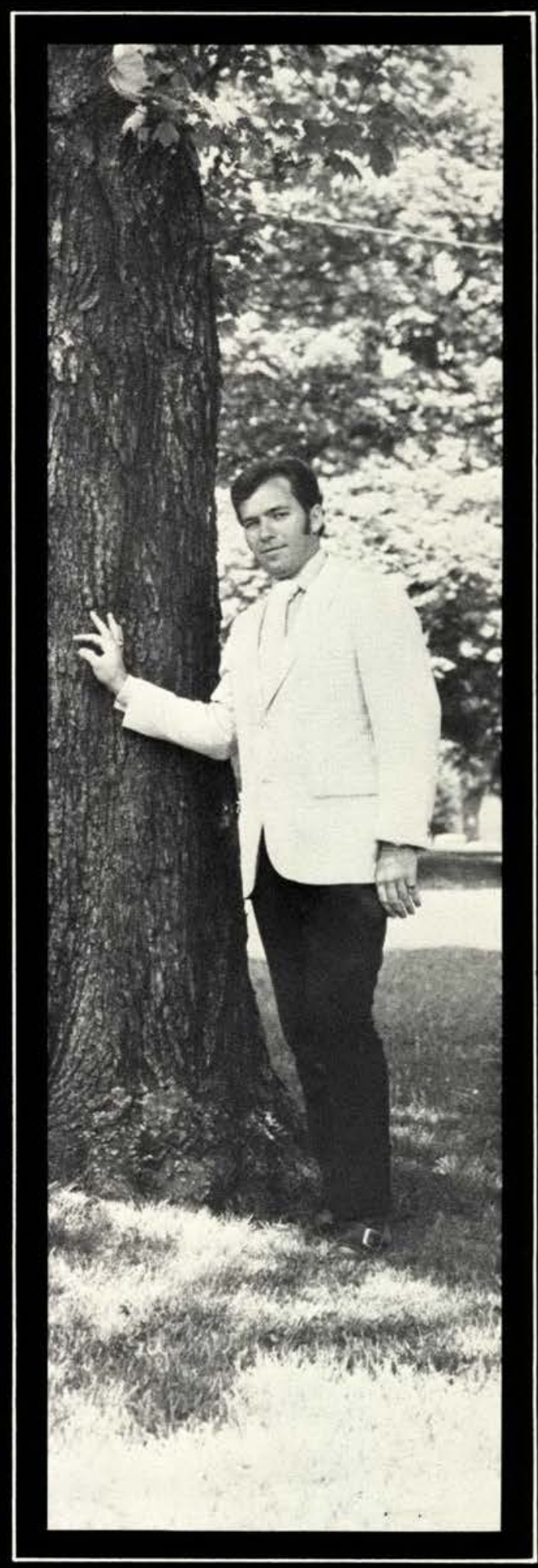

Mike Wilhite 


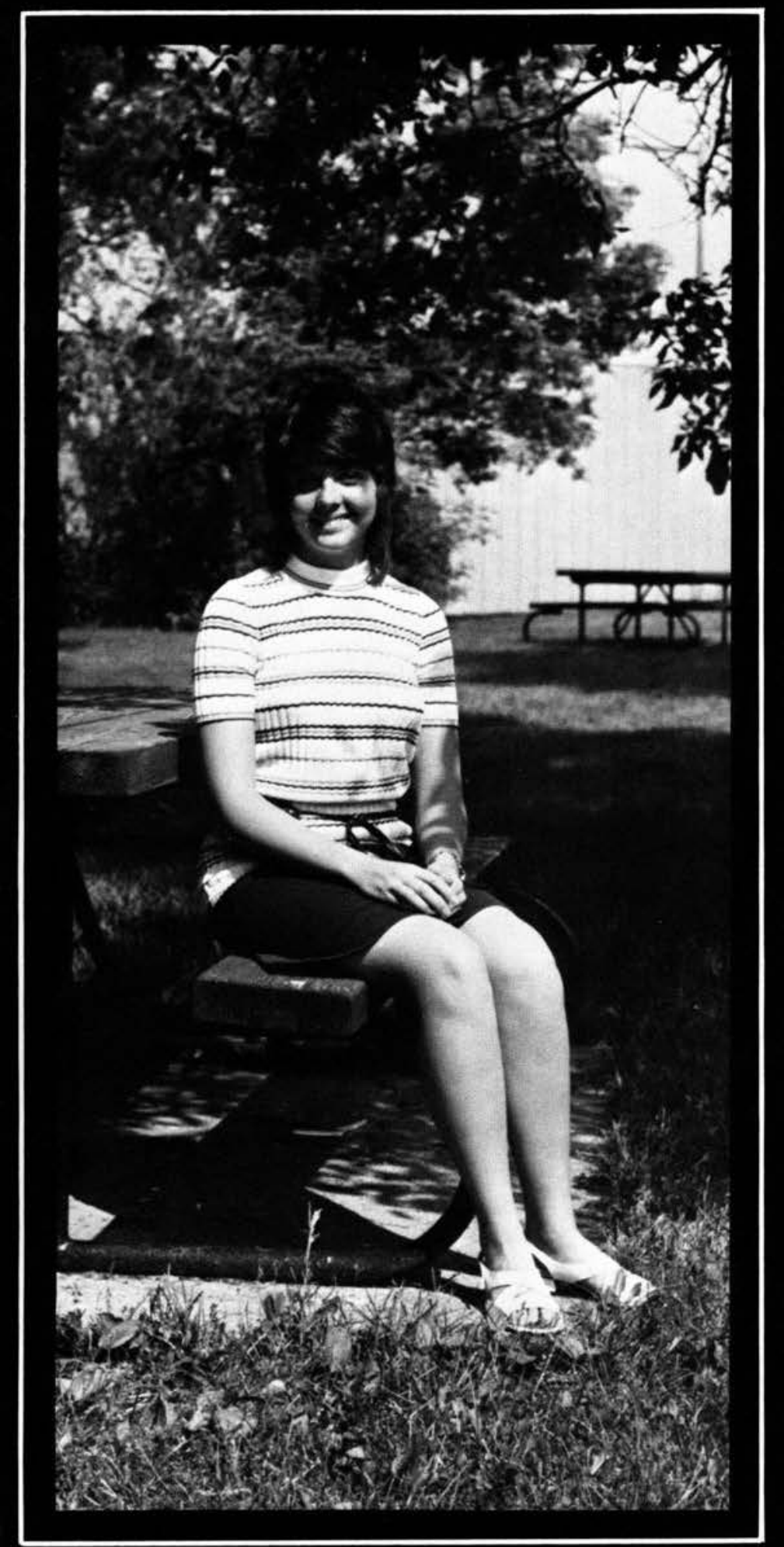

Kathy Endres

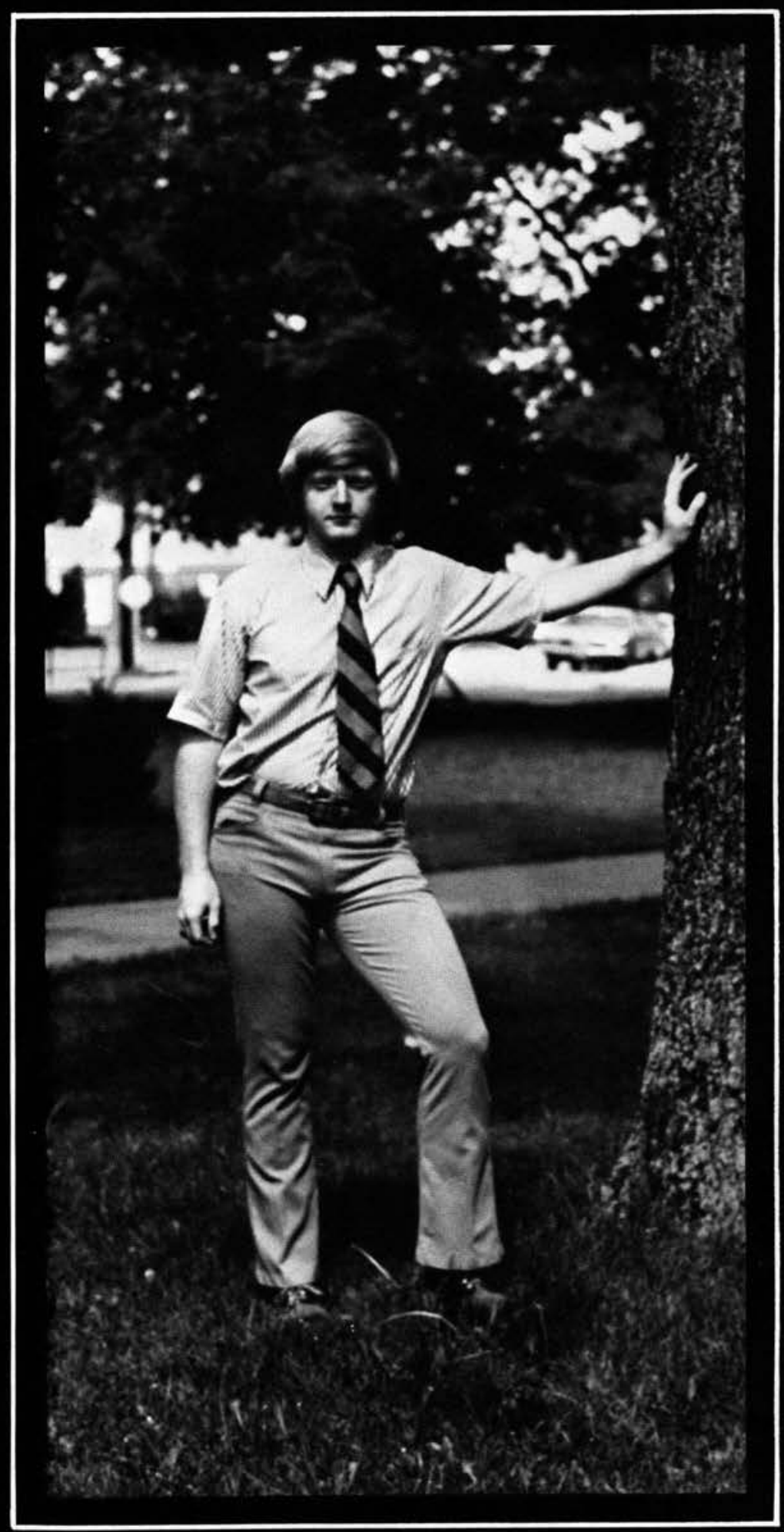

Jeff Woodcock 


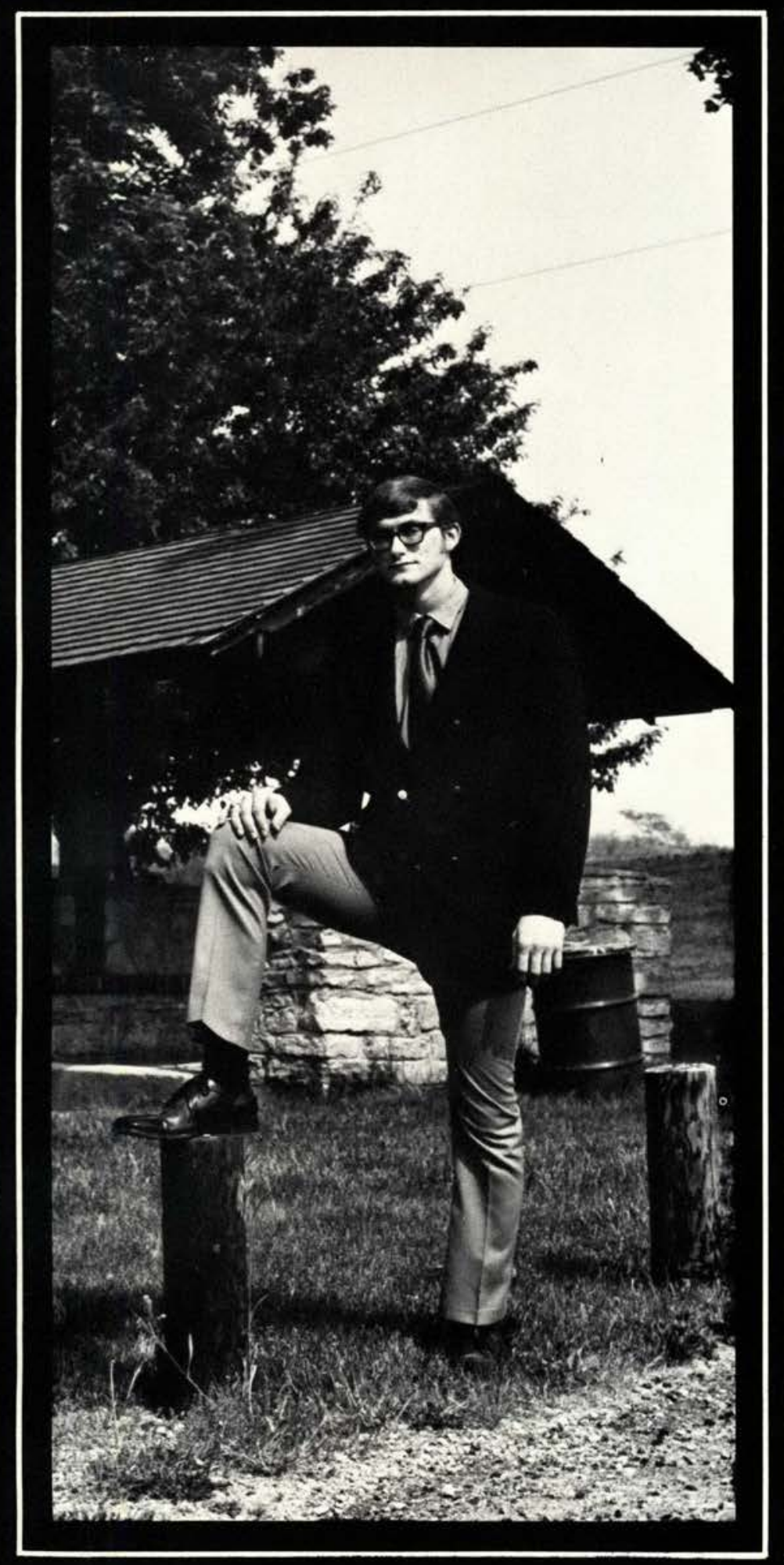

Dave Globig

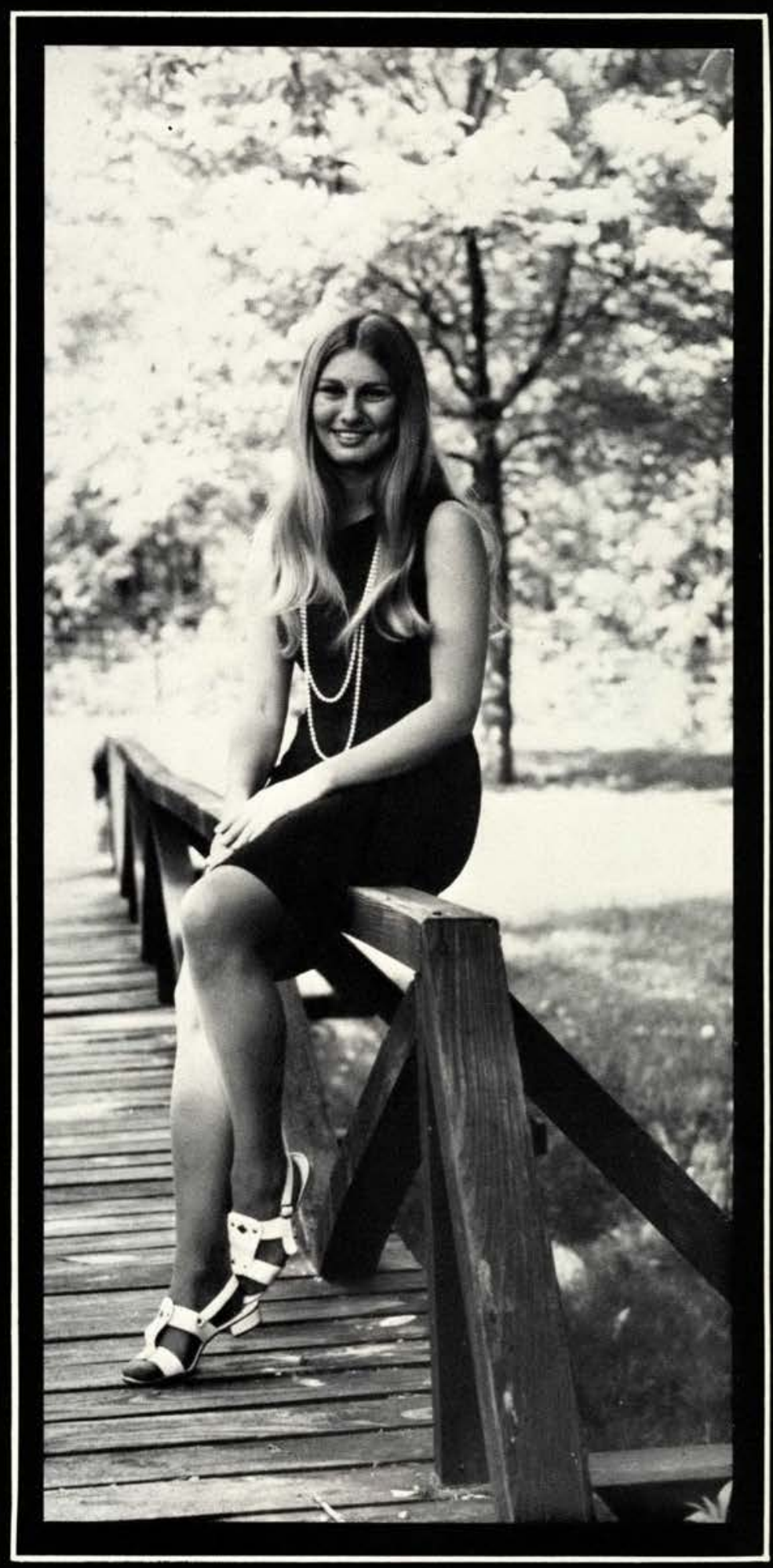

Sue Scott 


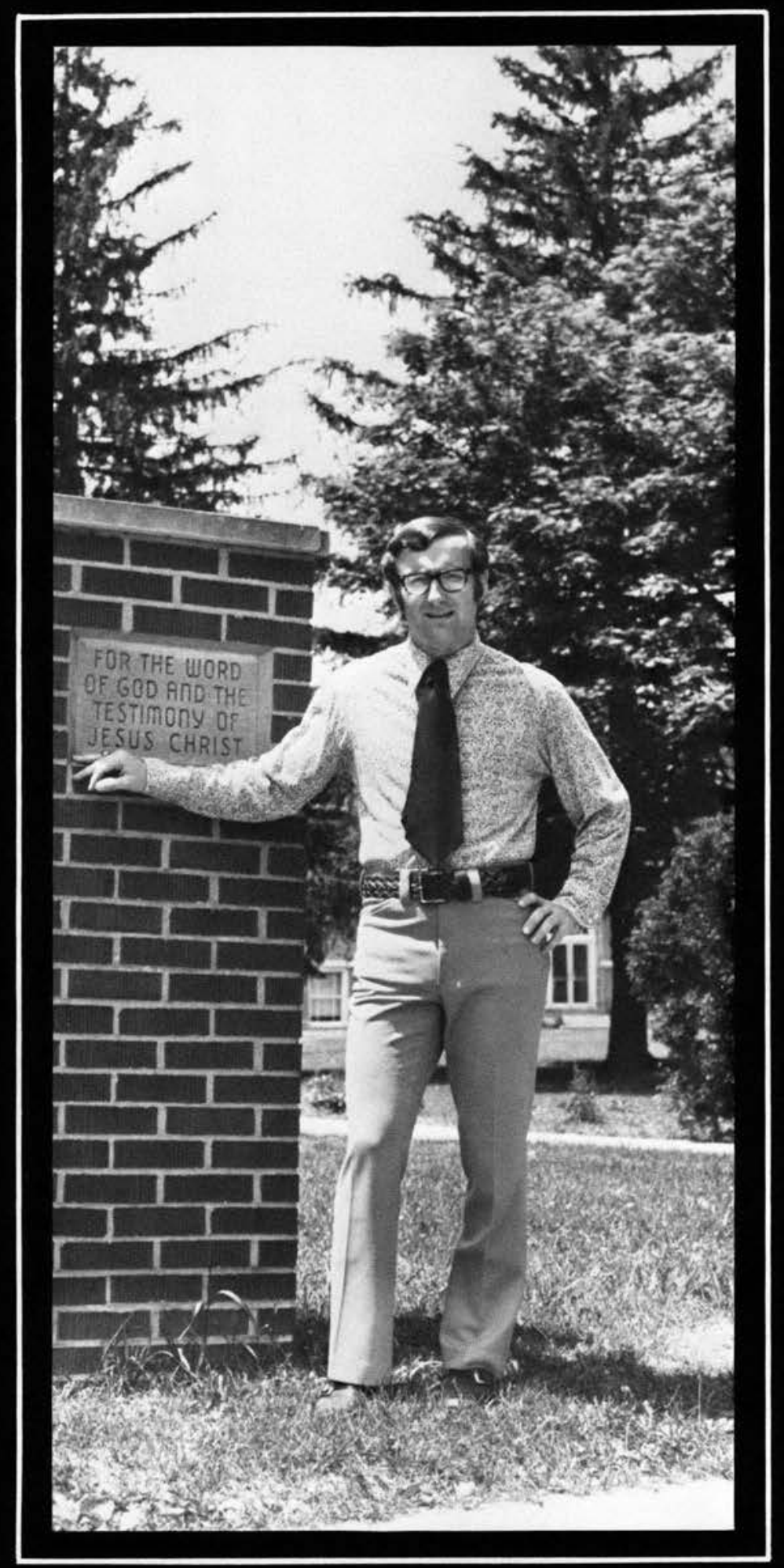

Phil Stine

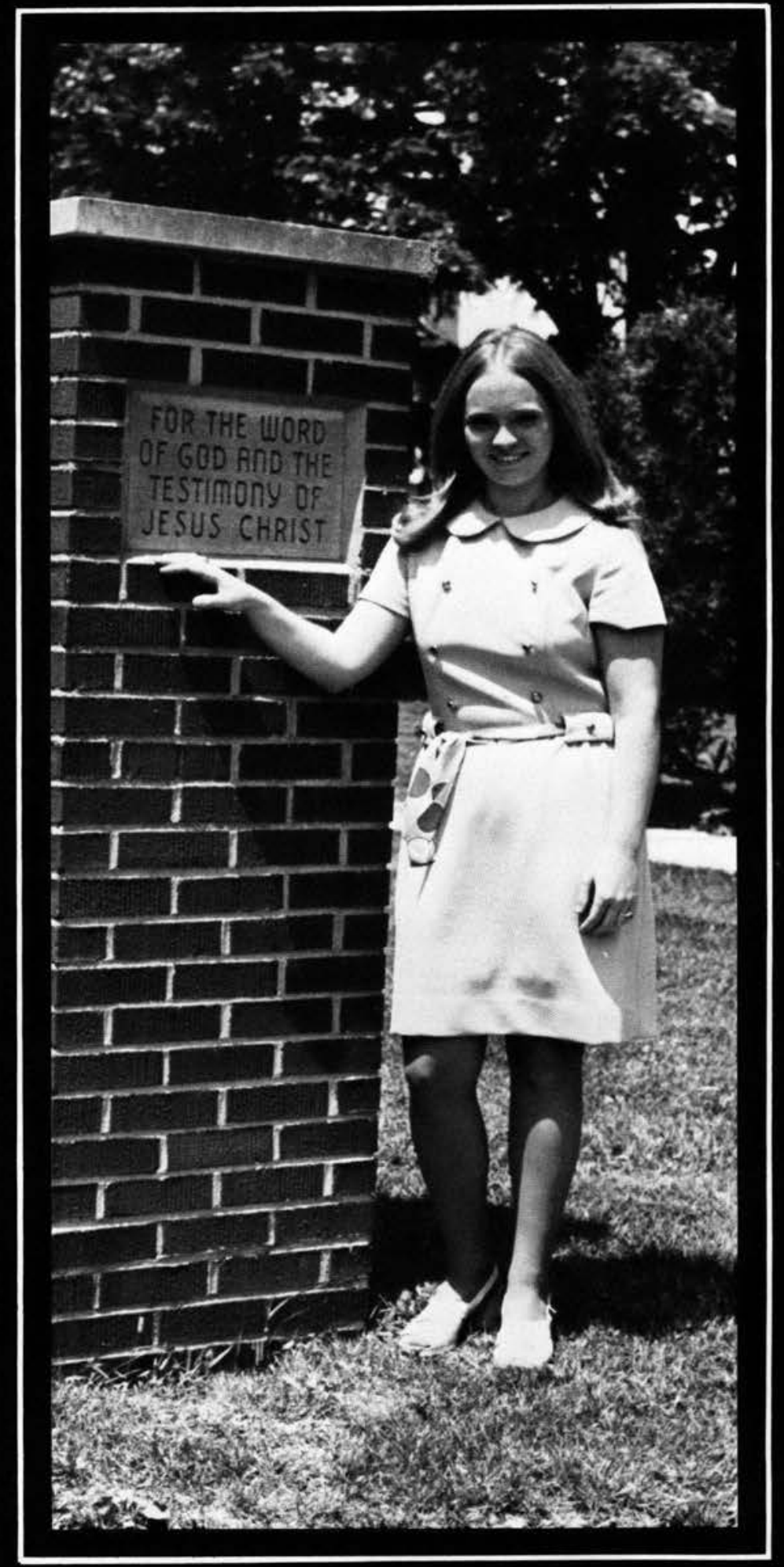

Sue Moore 


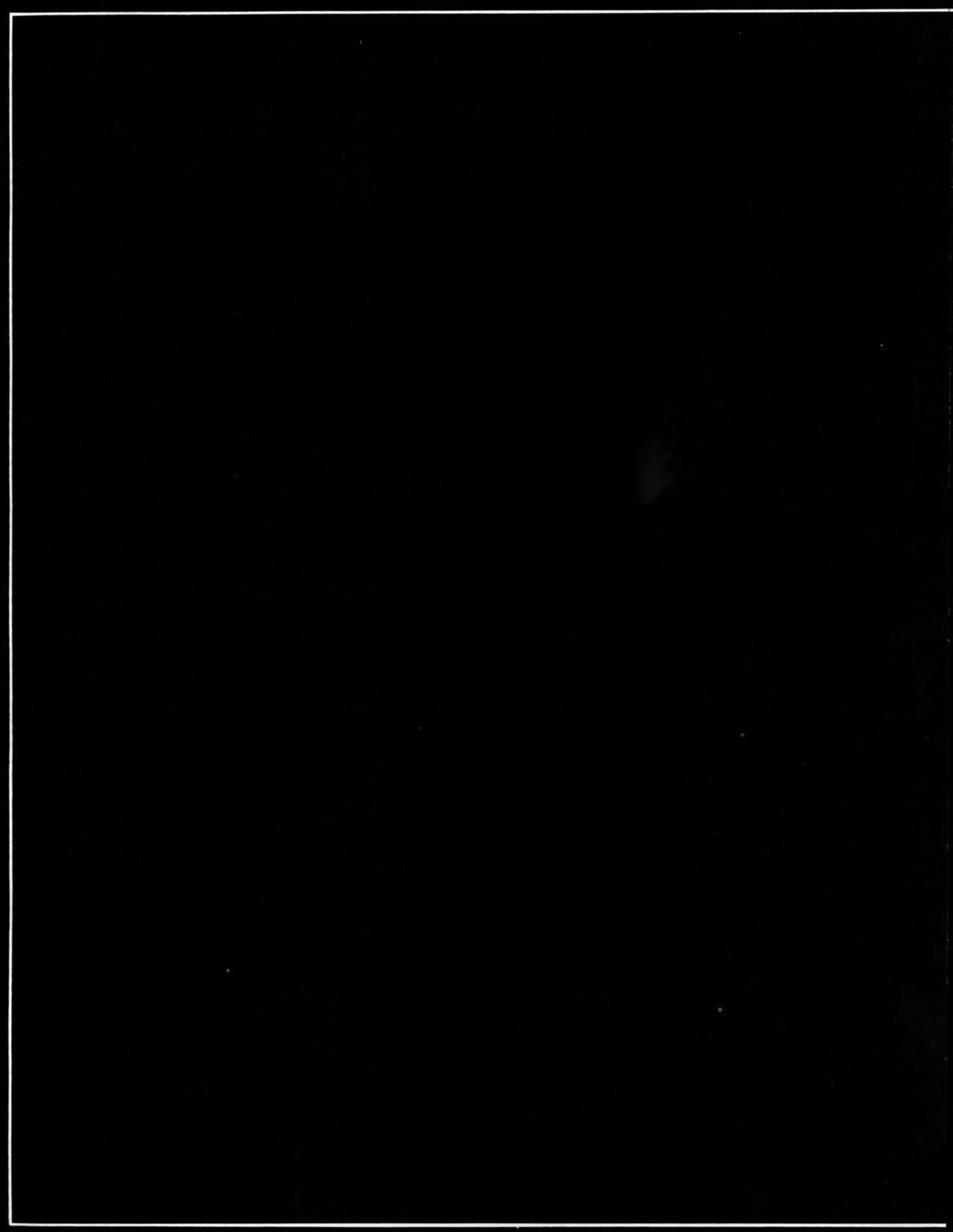



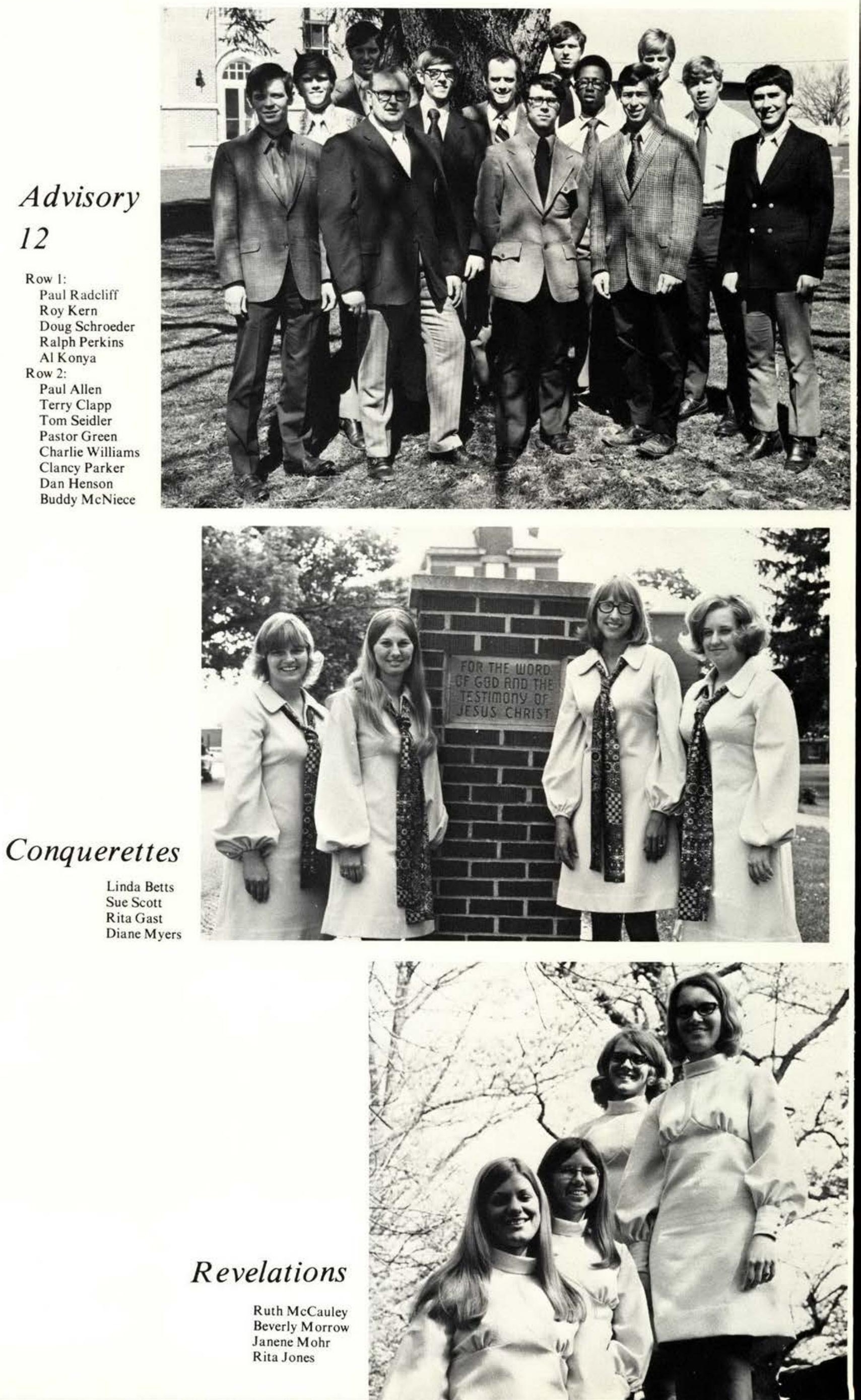


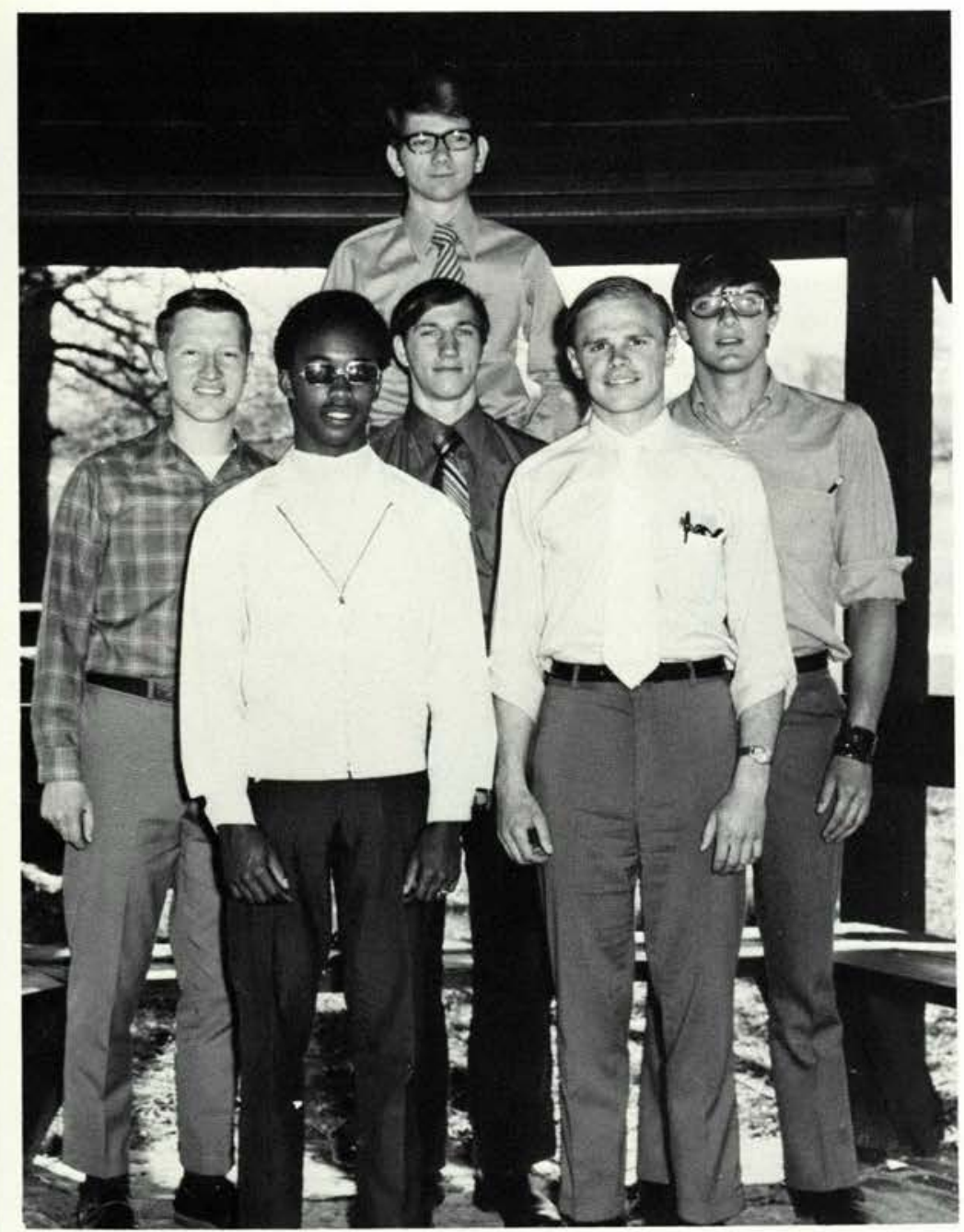

Sigma Delta Kappa

Row 1:

Lynn Mitchell

Dave Mallinack

Row 2:

Gene Peterson

Bill Tobias

Rich McGhee

Row 3:

Jeff St. Clair

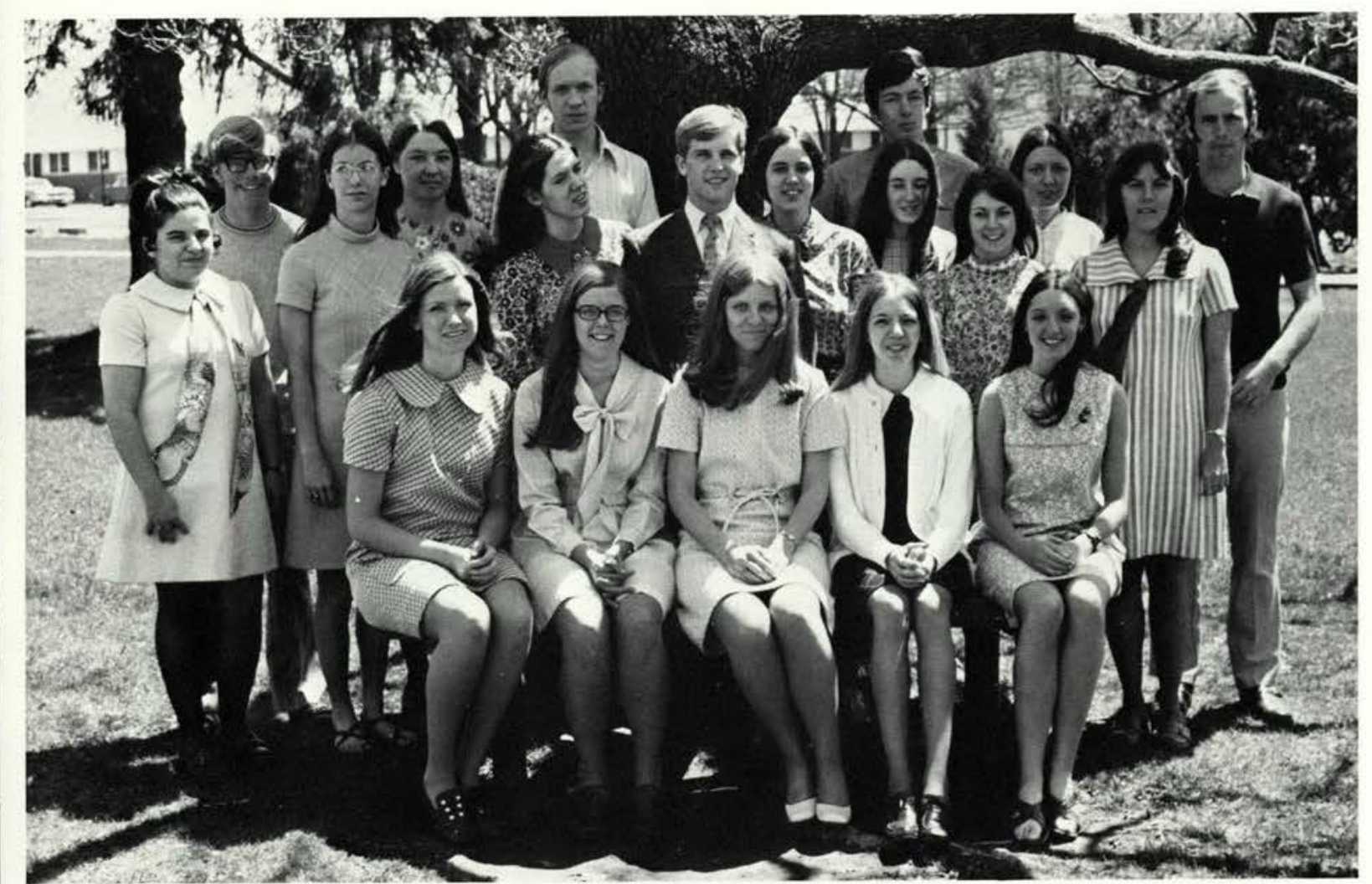

Rest

Homes

Seated: Cindy Mally, Carol Johnson, Sharon Byers, Mable Young, Chris Bernath; Standing: Debbie Good, Bob Sampson, Mary Ann Butcher, Cindy Wiggins, Cathy Sharp, Glen Kemery, Lyle Miller, Carolyn Bonnell, Holly Jenkins, Eldon Sarver, Kathy Strawn, Debbie

Samson, Jolene Byers, Dave Eller. 


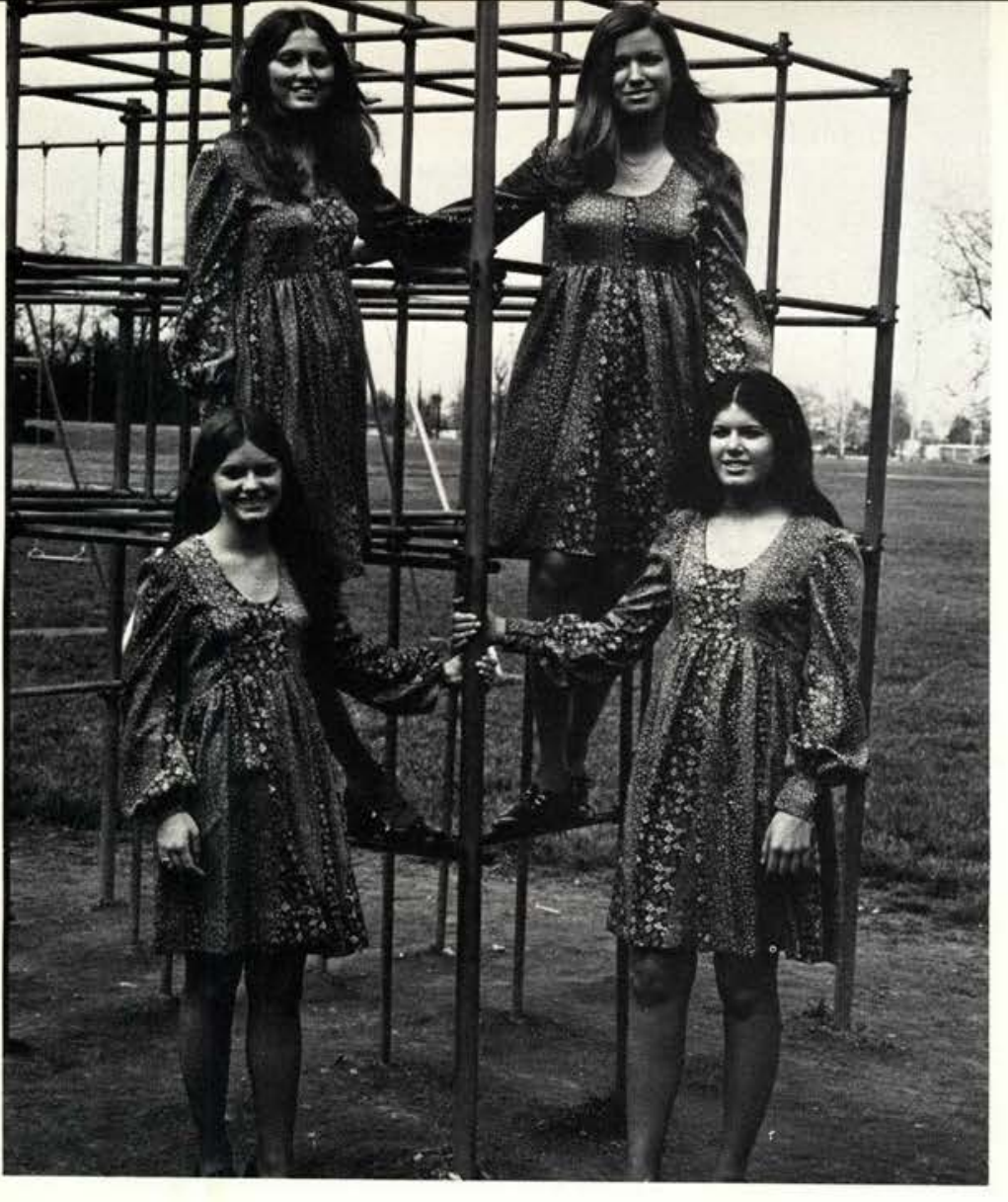

Manifestation Trio

Barbara Bickford, Georgeanna Axiotis, Cindy Mally, Marleah Namy.

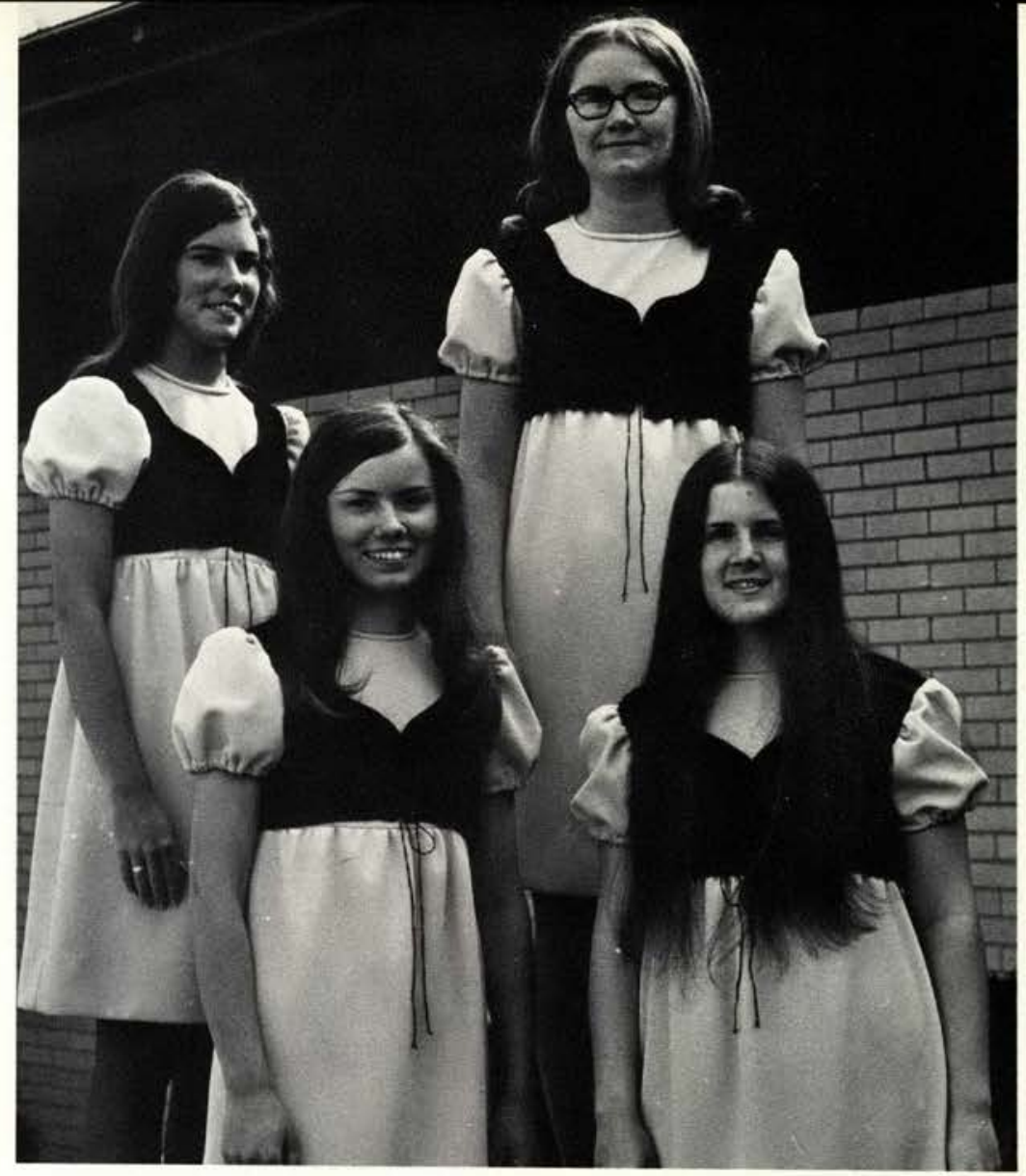

\section{Gospel Echoes}

Yvonna Cope, Rosalie Howard, Rae Belle Fisher, Nancy Tallman.

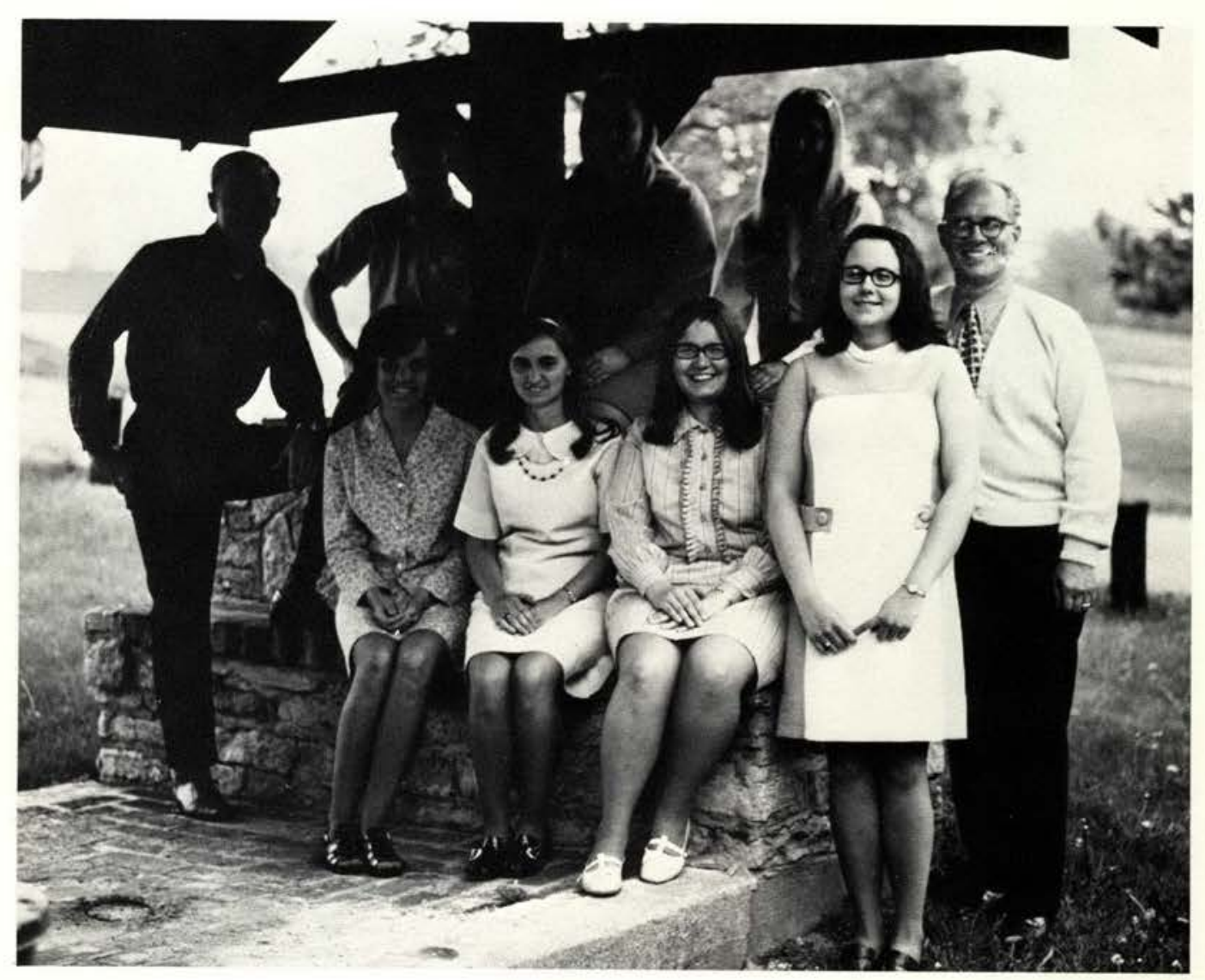

Karen Stephenson

Carolyn Stubrich

Marjorie Cogan Row 2:

Dave Mallinack

Jacob Tipton Linda Phelps

Sue Scott

Ruth Ann Steyers Dr. Jack Scott 


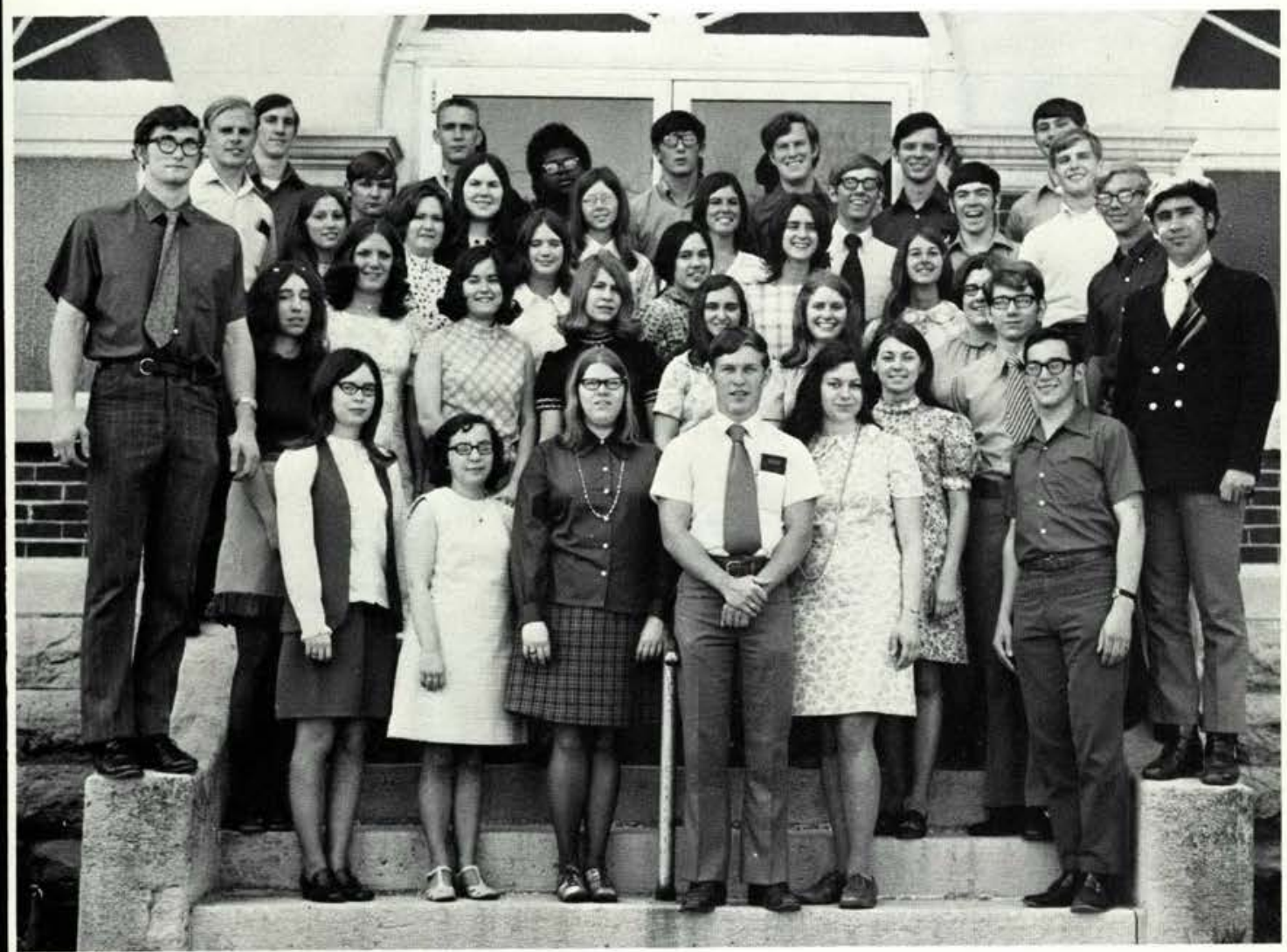

\section{Swordbearers}

Debbie Davis

Molly Rehn

Esther Schultz

Debbie Earnhar

Debbie Conrad

Lois King

JoAnn Brown

Linda Christiansen

Marcea Bearss

Brenda Will

Sue Moore

Carolyn Stubrich

Ben Gunneson

Joyce DeBruine

Rhea Johnson

Kelsey Bennett

Kathy Henderson

Janet Young

Dennis Twigg

Bette Warfield

Rex Rogers

Ken Carlton

Sarah Stone

\section{Bible Clubs}

Row 1: Bernice Penegor, Carole Kies, Nancy Layne, Jacob Tipton, Diane Jacobs, David McDaniel; Row 2: Dave Globig, Cindy Rentis, Karen Young, Debbie Dear, Suzanne Hale, Carolyn Stubrich, Sue Seldon, Kathy Strawn, Jeff St. Clair, Al Konya; Row 3: Dave Mallinack, Georgeanna Axiotis, Debbie Jones, Debbie Banks, Carolyn Bonnell, Becky Canine, Joyce Mohler, Jan Shawver, Ken VanLoon; Row 4: Bill Tobias, Rick Gerver. Chris Orton, Bev Morrow, Yvonna Cope, Tom Seidler, Dennis Twigg, Lyle Miller; Row 5: Mark Bohland, Jerry Gilyard, Rich McGhee; Steve Overholt, Paul Radcliff, Bruce Klett.

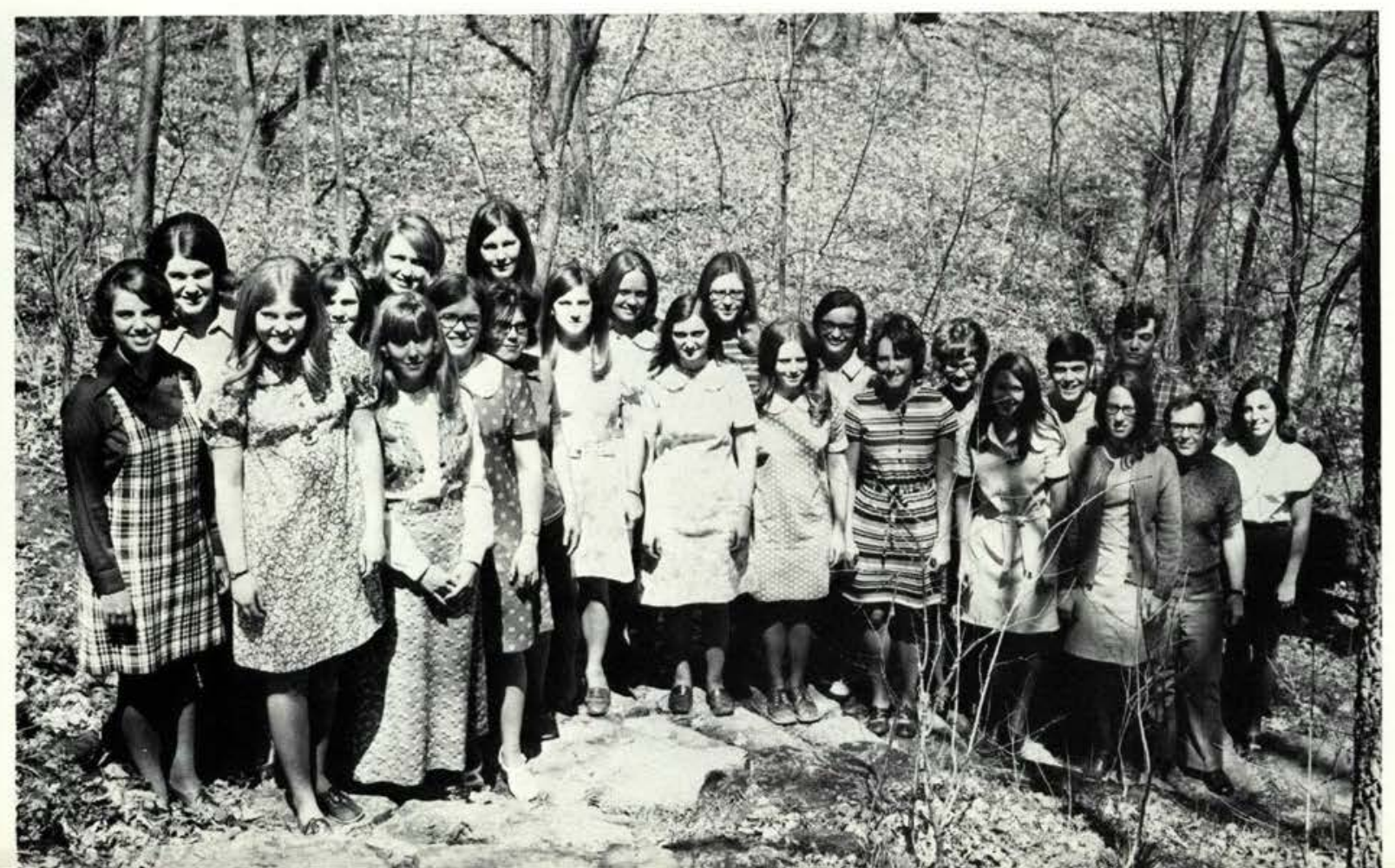




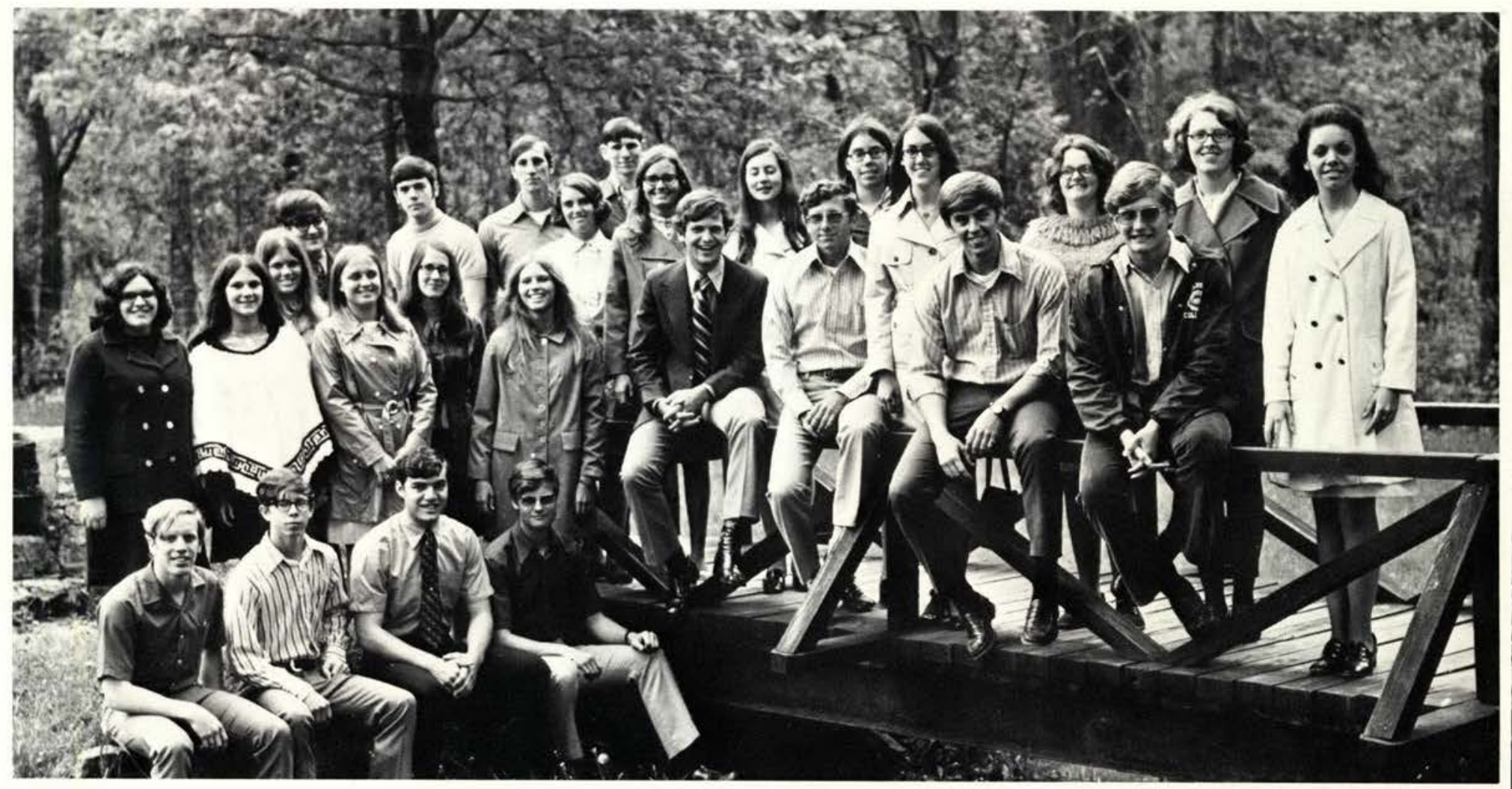

\section{OS SO}

Row 1: Don Davis, Roy Perkings, Rex Rogers, Dale Mugglesworth; Row 2: Holly Detrick, Karen Wimer, Bev Davison, Dinah Arthur, Valerie Holfield, Faye Salomon; Row 3: David Butler, Dennis Twigg, Bil Tobias, Debbie Davis, Robert Norton, Becky McDonald, Doug Hess, Sue Sagendorf, Chuck Newhaus, Sarah Harriman, Anita Schneider, Don Erickson, Judy Johnson, Wayne Aldrich, Bonnie Dedrick, Darlene Jones.

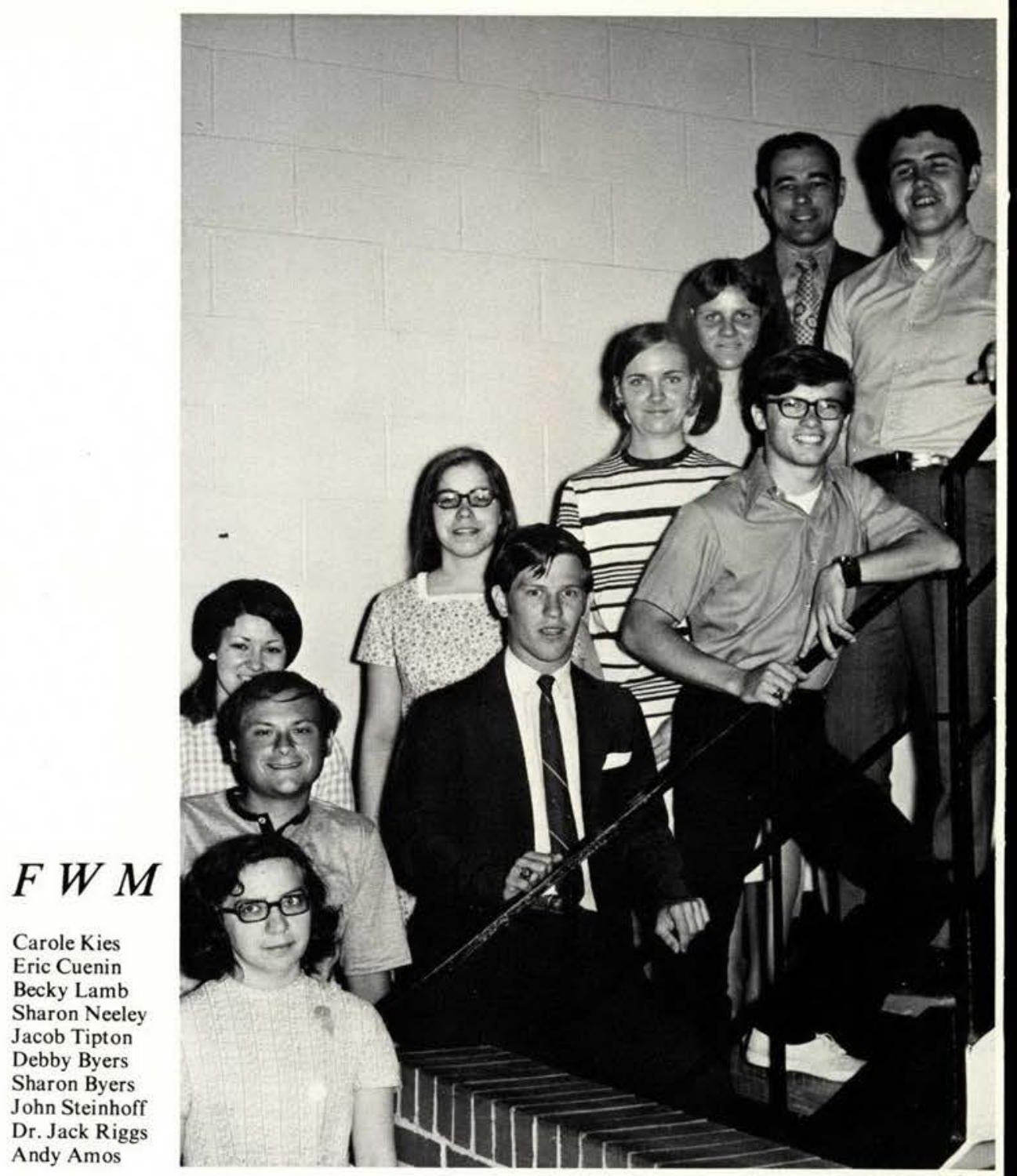




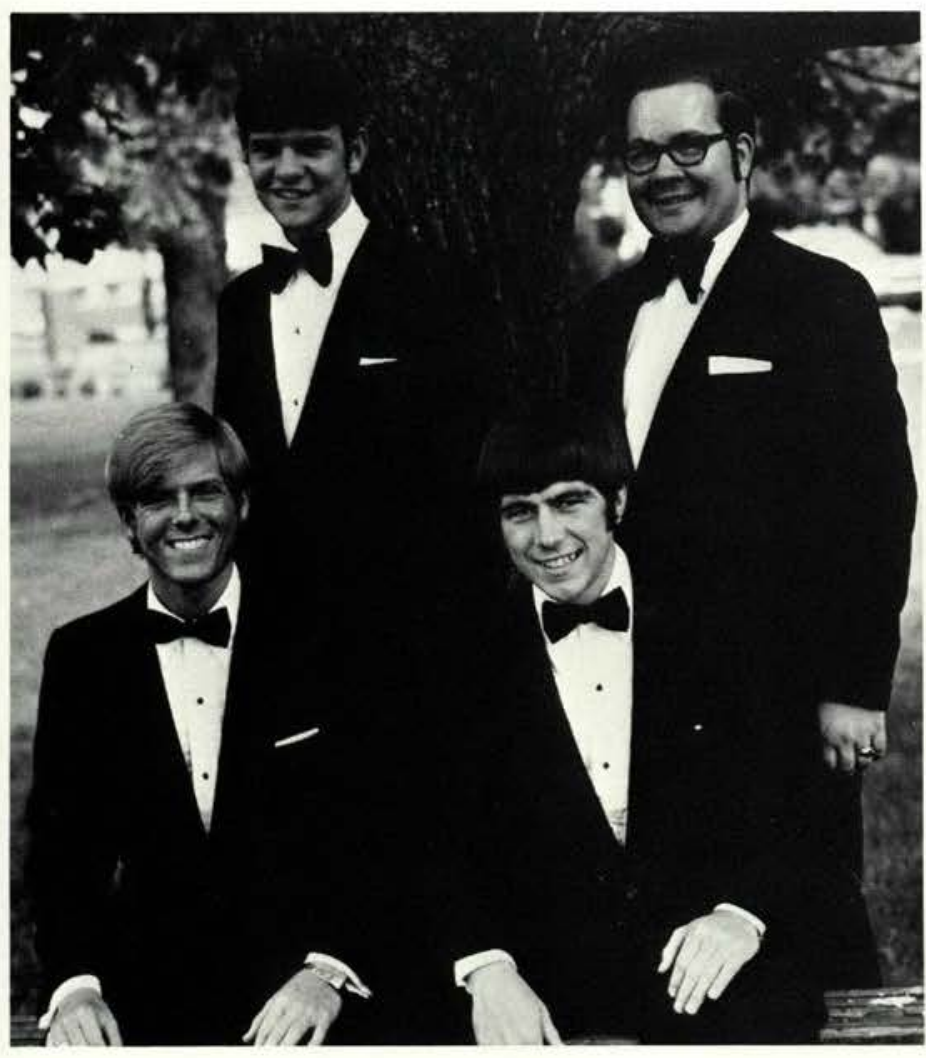

Men's Trio

Dennis Roberts, Dan Steman, Steve McCallister, Ron Jutton.

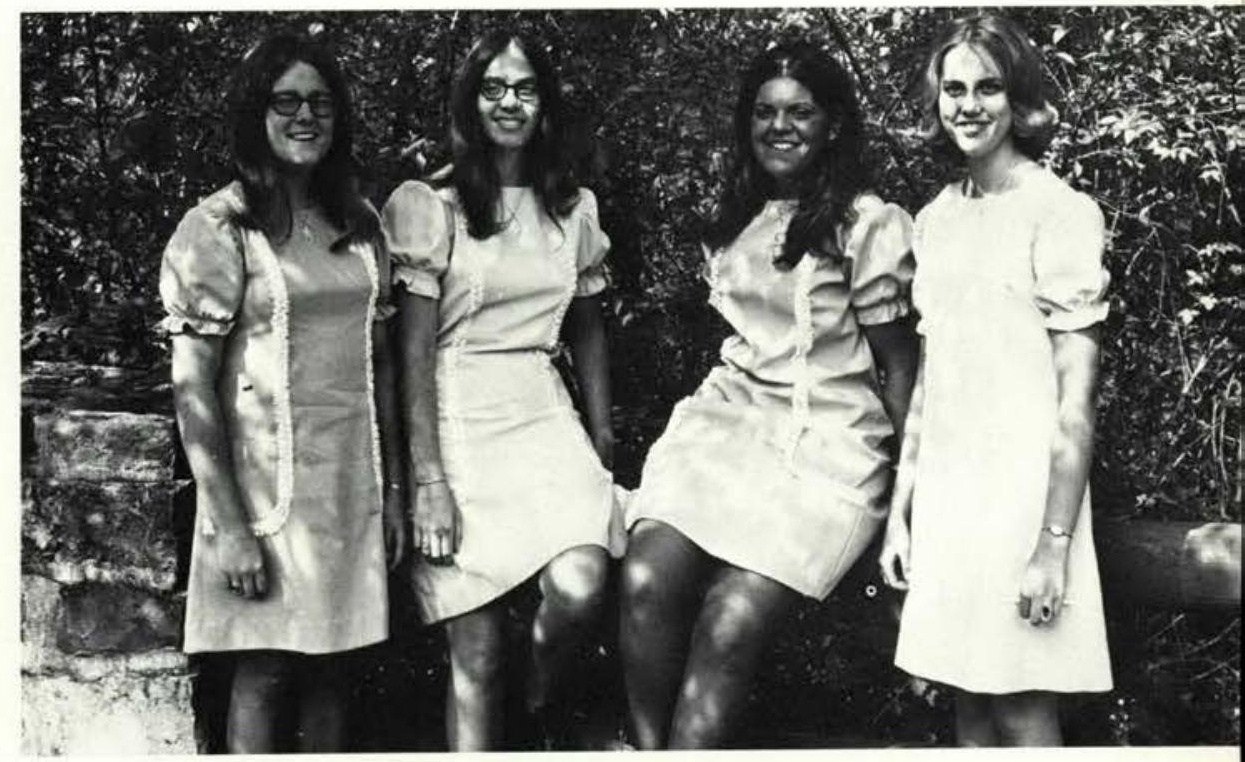

The Discoverers

Joyce Self, Sherilyn Hansen, Becky Kemble, Becky Anderson.

\section{Detention Home}

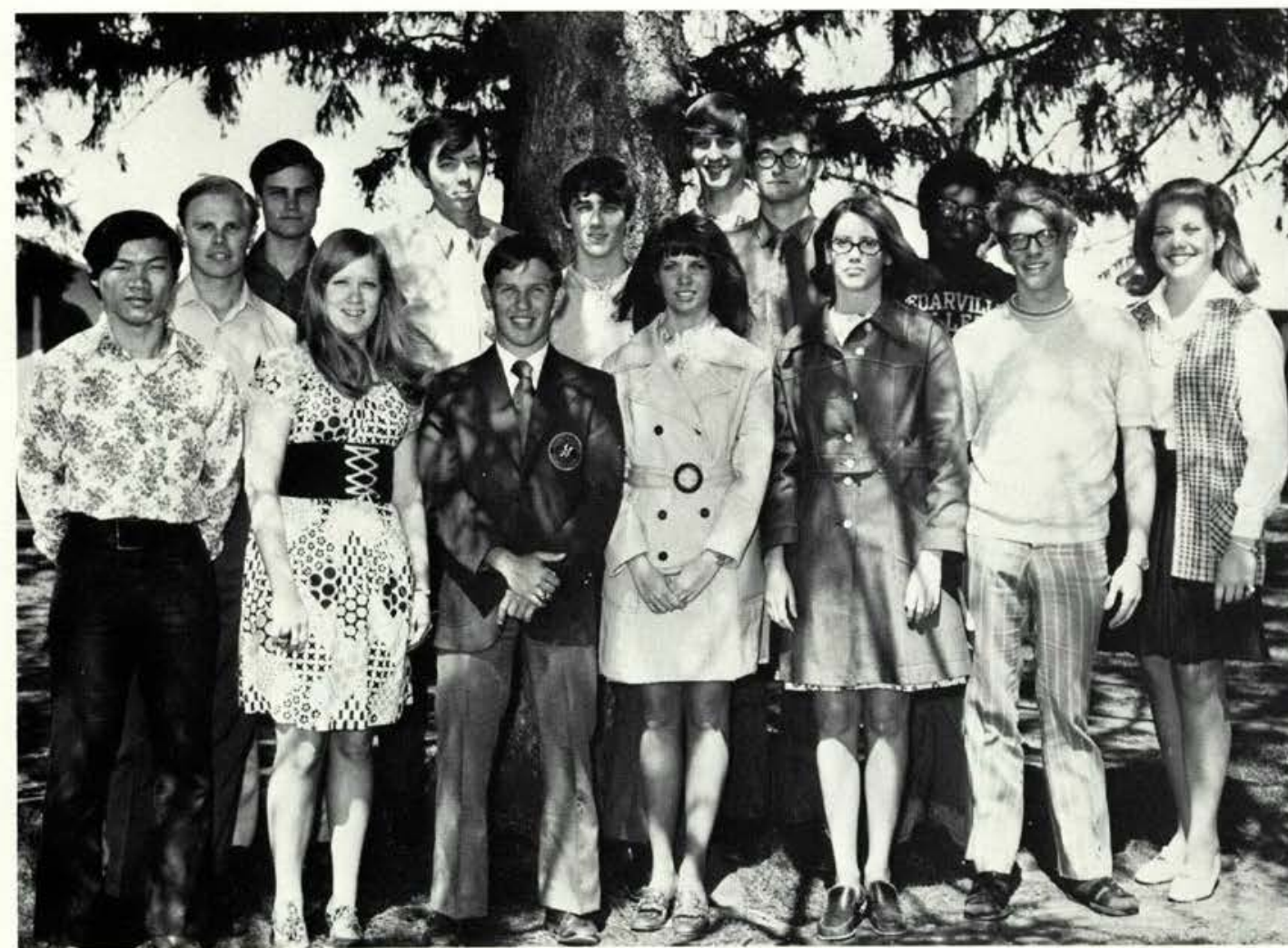

Row 1:

Boonchuay Lysoonan

Raynelle White

Jacob Tipton

Debbie Eplee

Bertha Carter

Bob Sampson

Carol Bierbaum

Row 2:

Dave Mallinack

Dale Muggleworth

Eldon Sarver

Rod Robinson

Steve Larson

Dave Globig

Jerry Gilyard 


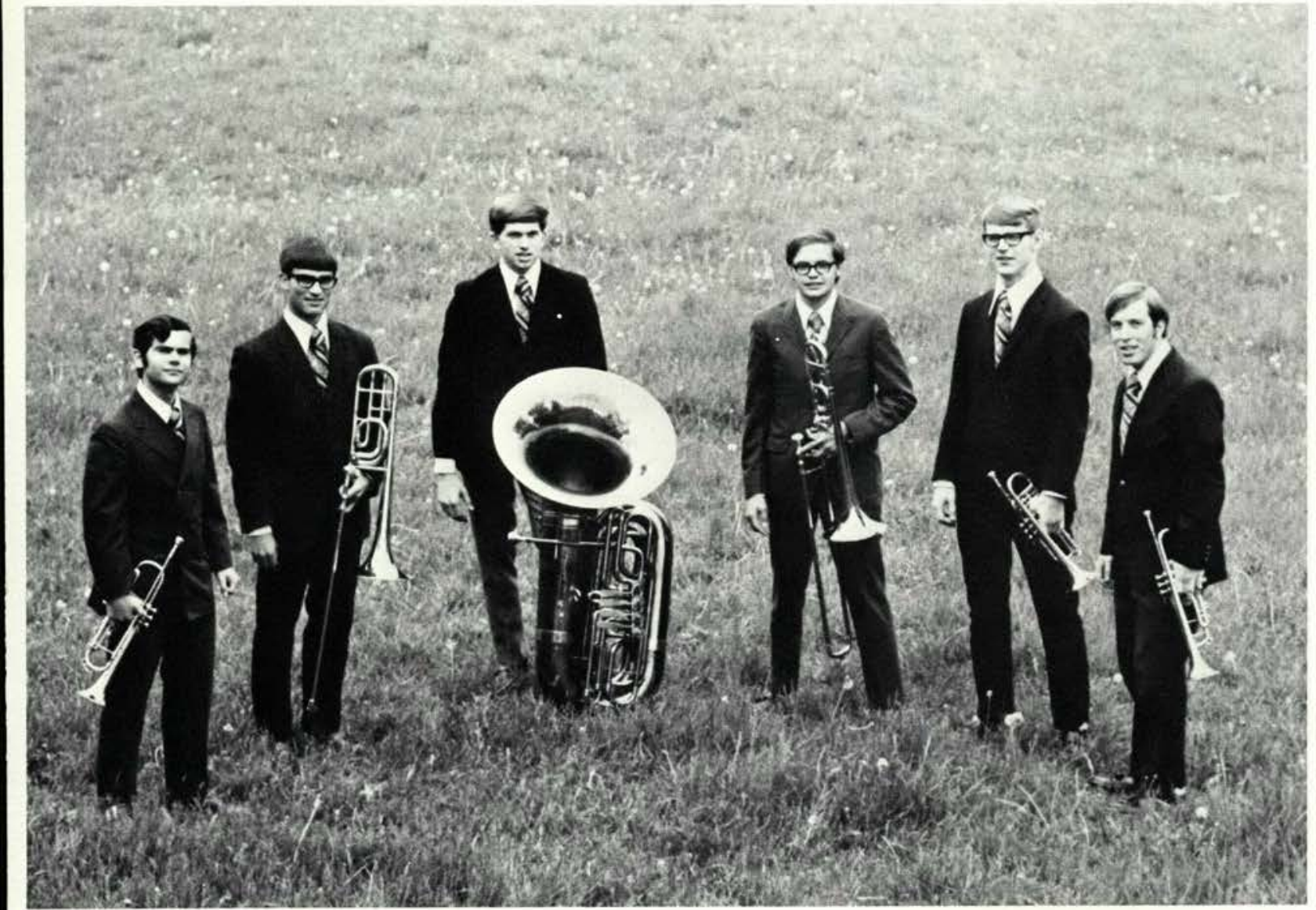

Brass

Sextet

\section{Kevin Sims}

David Webber

Loren Small

Mark Sloan

Tim Barker

Tim Hegg

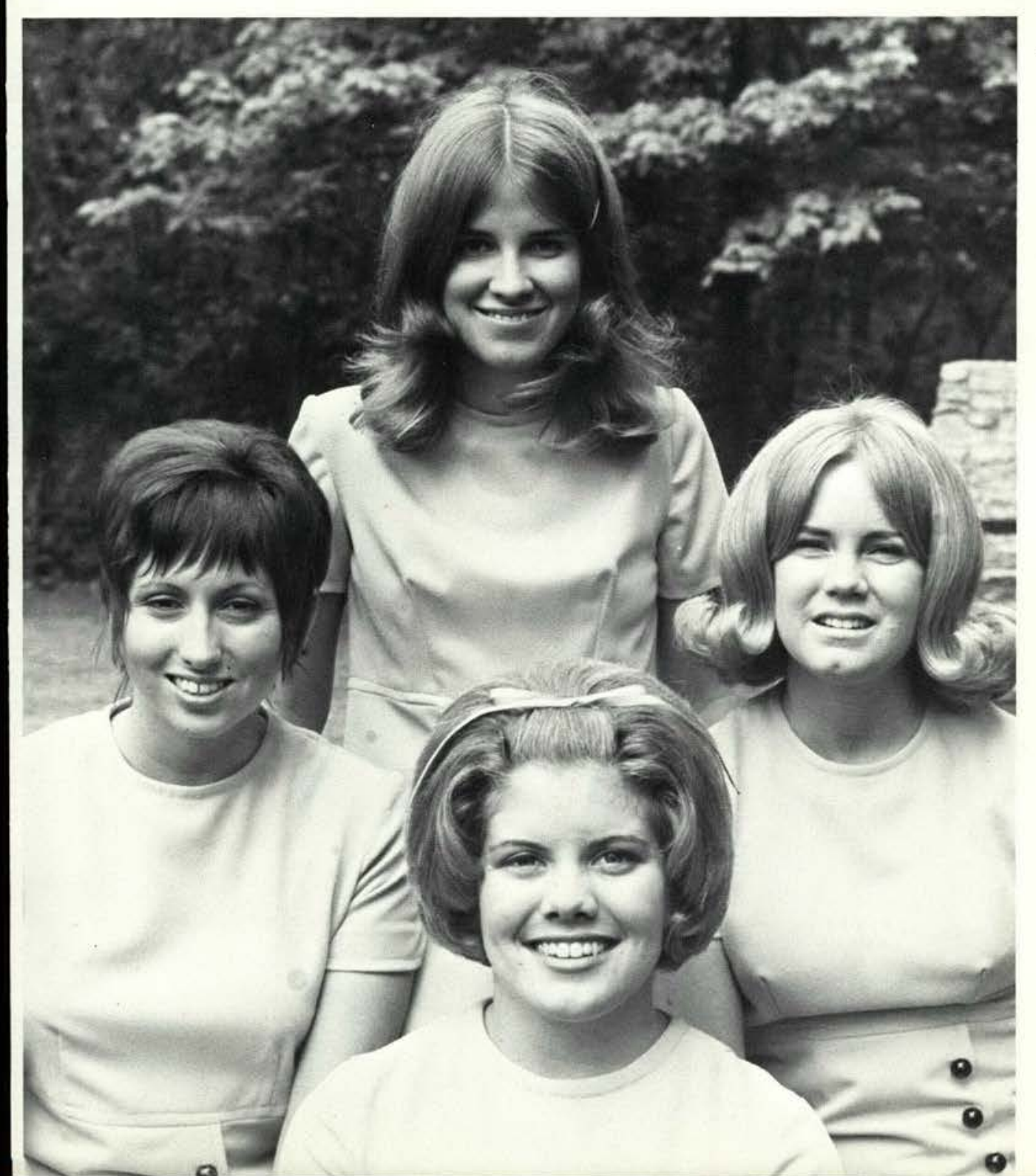

Reflections

Trio

Becki Chandes

Paula Prater

Carol Bierbaum

Kathy Burkhard

\section{Groups}

Tour

U.S.A.

in

Summer of

1971 


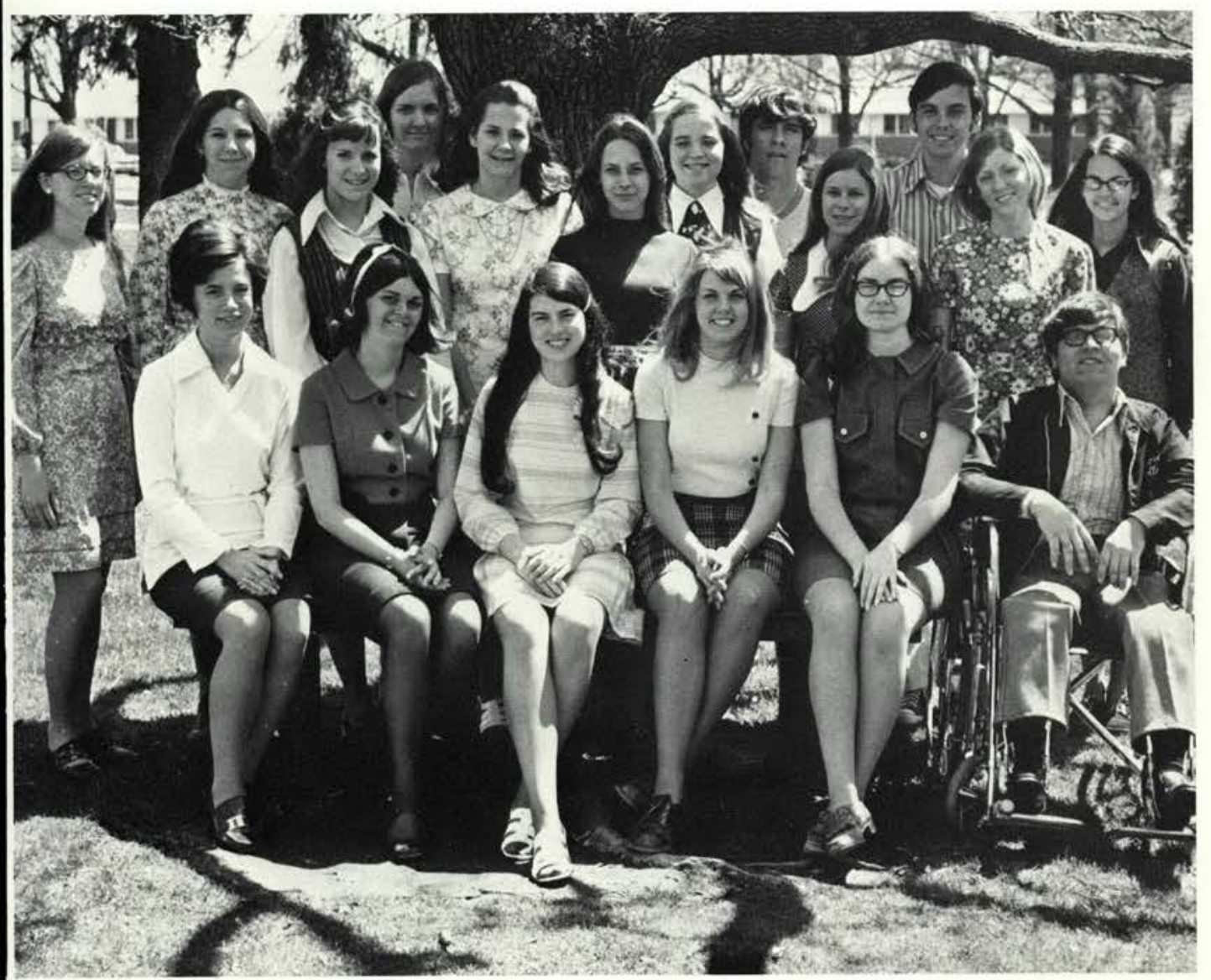

Rest

Homes

Seated: Ginny Heal, Judy Vine, Sharon Reese, Jean Taylor, Rae Belle Fisher, Floyd Fisher; Standing: Becky Fight, Becky Duran, Andi Houchin, Debbie Byers, Jan Hillery. Sue Peacock, Linda Hill, Bob Mahl, Mary Gllenn, Dave Jewell, Karen Kennedy, Darla Stevens.

\section{Below:}

\section{Joy Clubs}

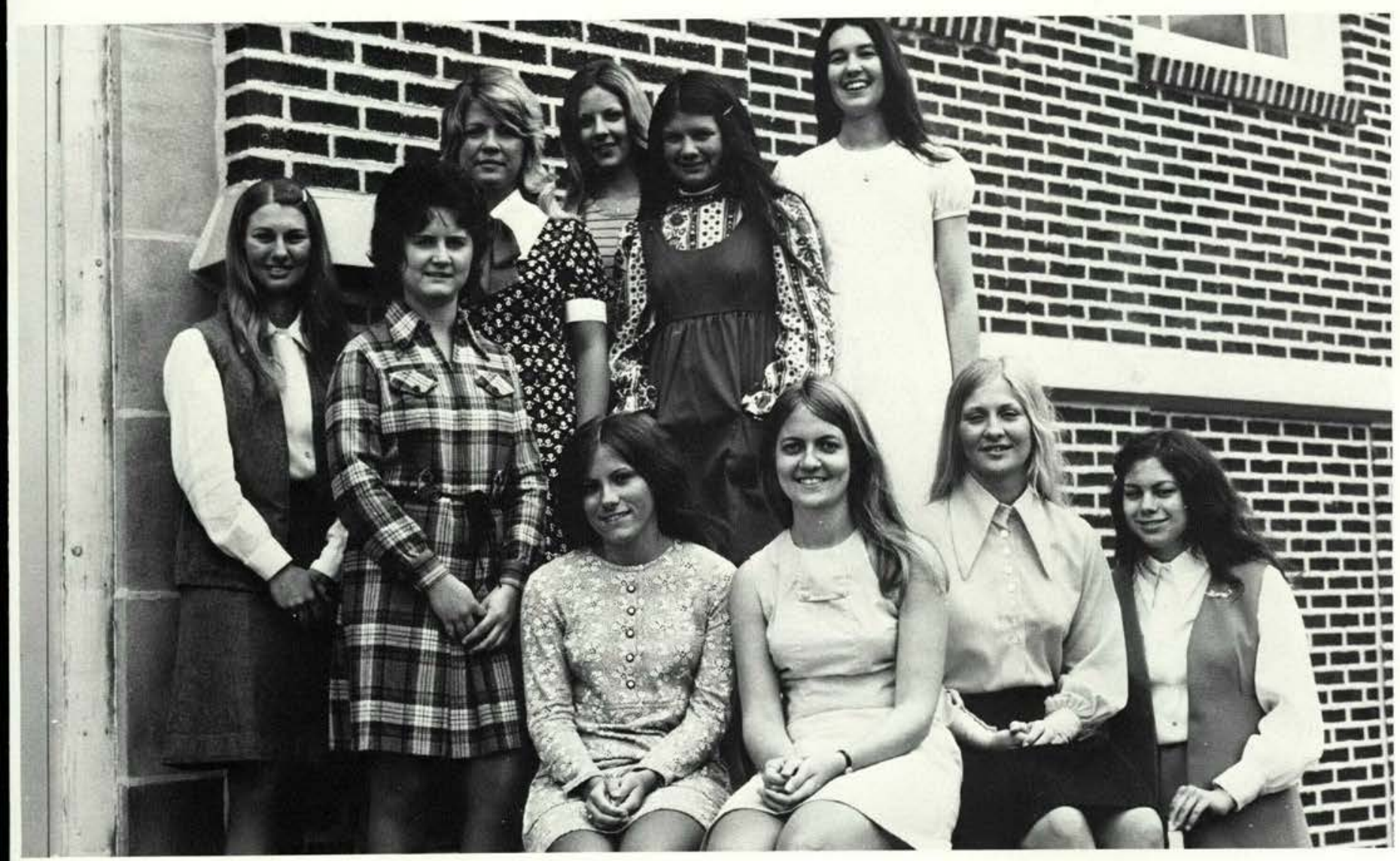

Row 1: Linda Chute, Ruth Gruenberger, Kathy Scott, Diane Jacobs; Row 2: Sue Scott, Bonny Bodenmiller, Melody Crotty, Mary Wood, Bev Kemp, Debbie Hostetler. 


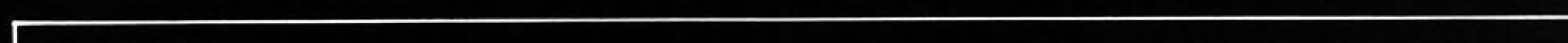




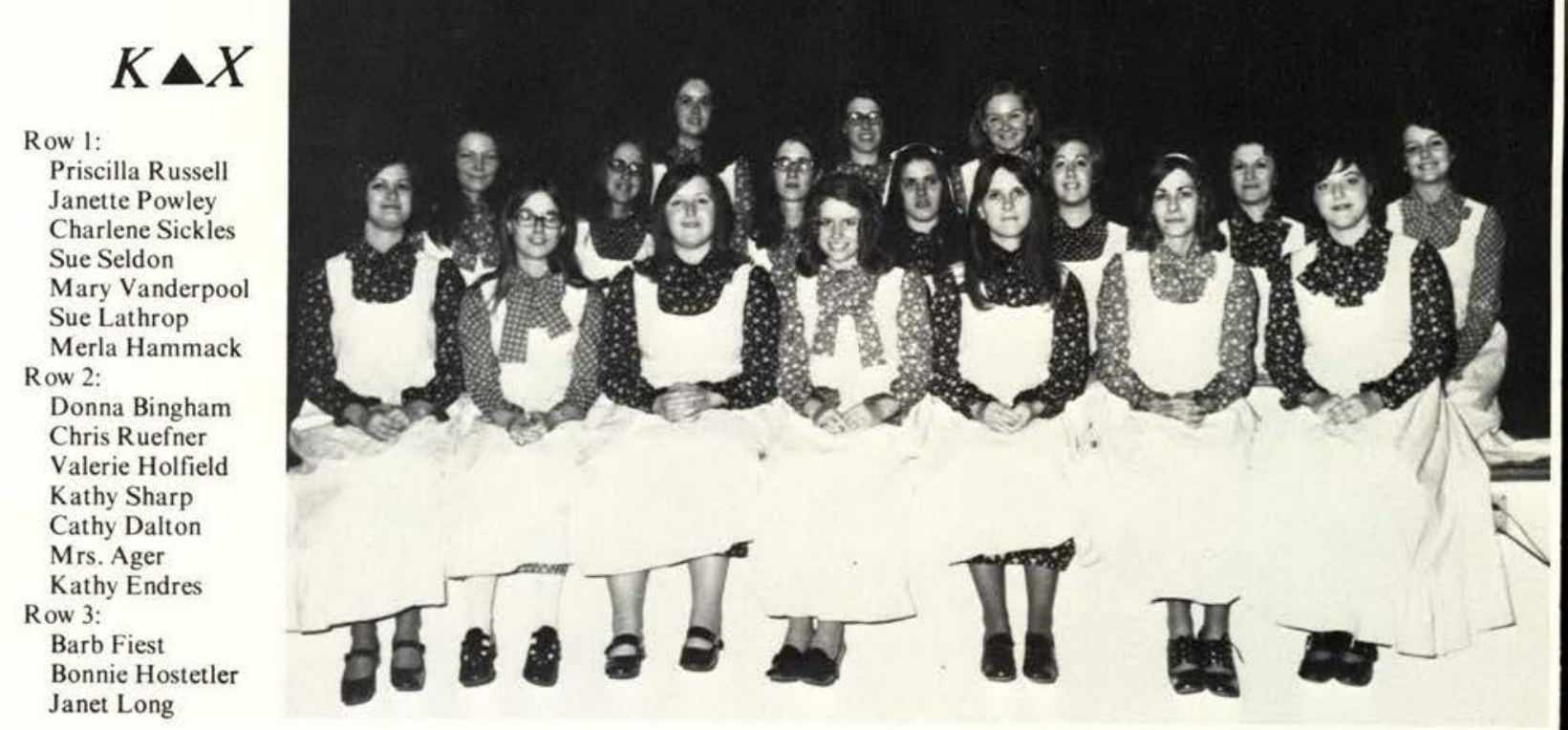

$W R A$

Row 1:

Sandy Finch

Joy Belle Erickson

Cindy Wiggins

Landra Grant

Connie Pumpelly

Roxane Davis

Kathy Scott

Cheryl Cressman

Julie Swallow

Jennifer Jaynes

Marianne Frauenknecht

Ann Good

Diane Craig

Jenny O'Neill

Linda White

Row 2 :

Rae Belle Fisher

Bev Pestel

Elaine Kalnbach

Brenda Tompkins

Karen DeMars
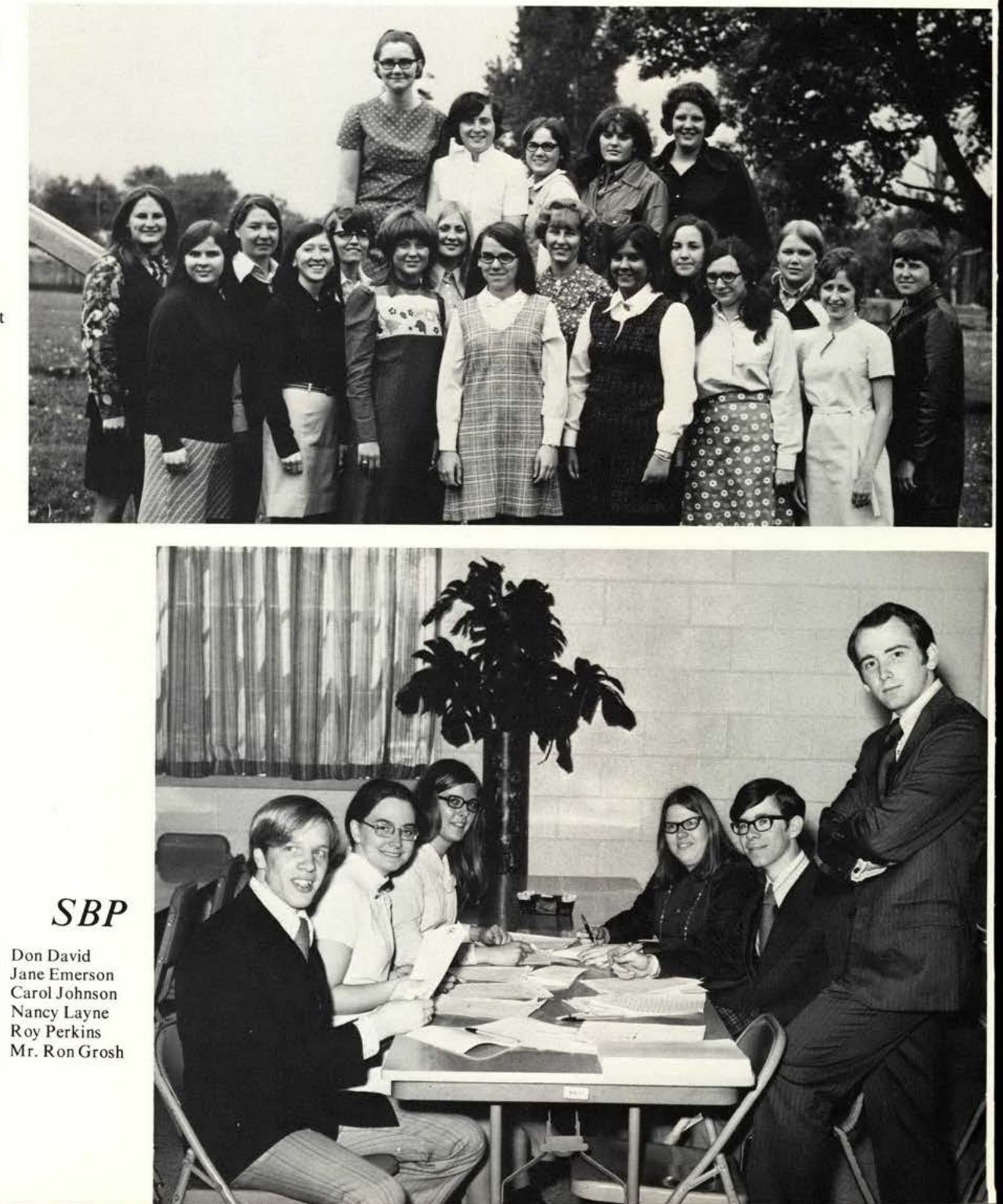

182 diversions 



\section{Cheerleaders}

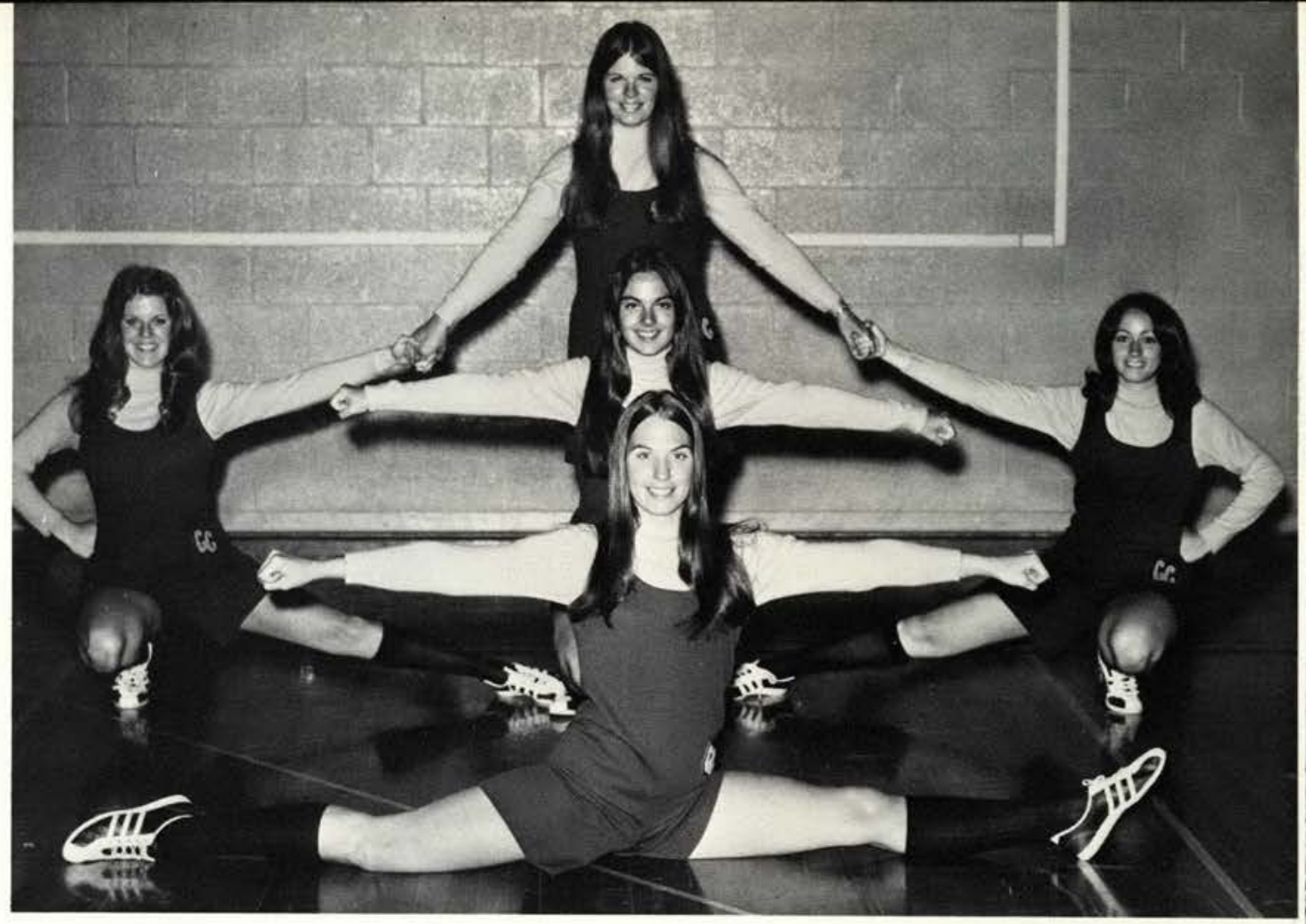

Vicki Huddleston Bev Davison

Debbie Jones

Kitty Parks

Leslie Leapline

Choir

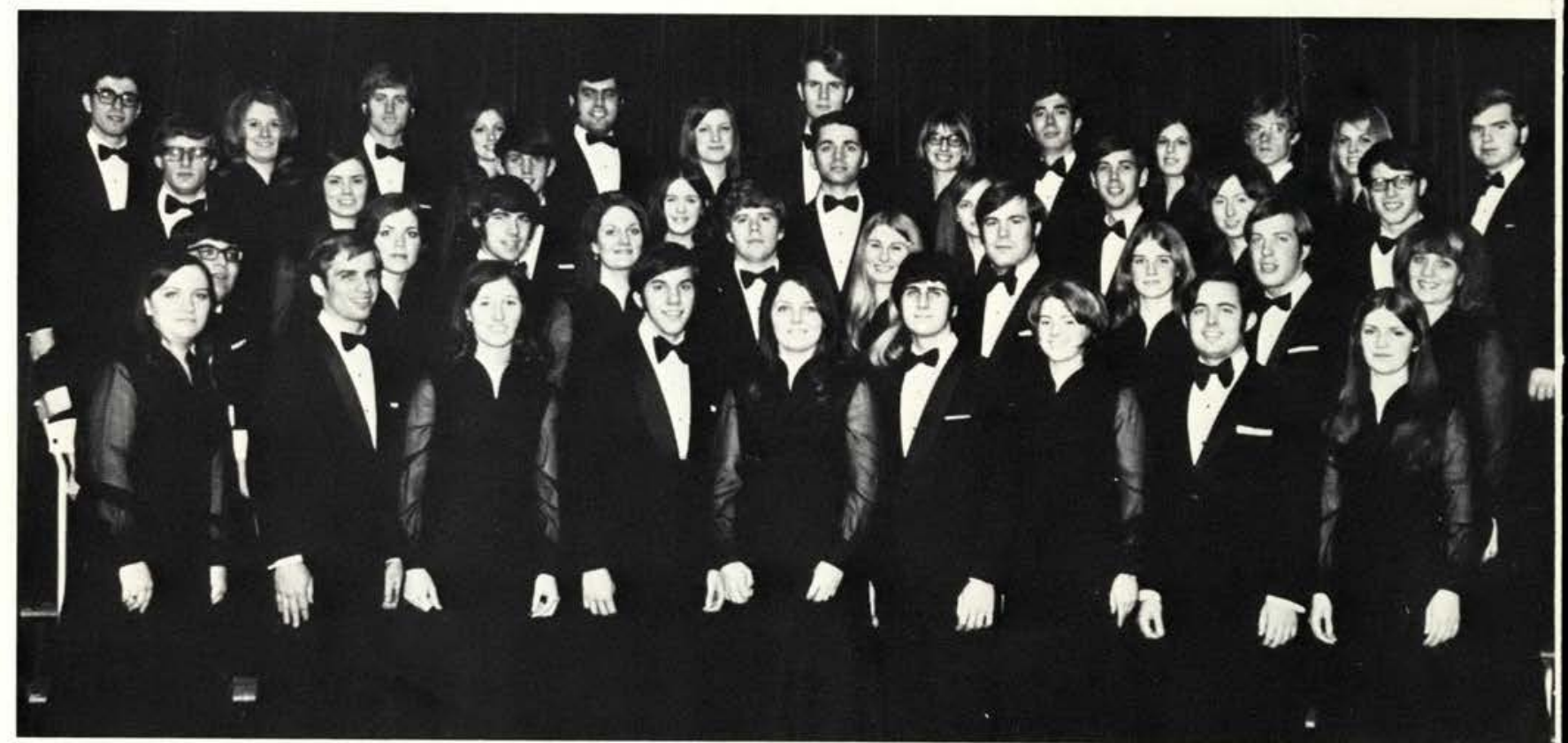

Row 1: Carolyn Lambert, Yontz Miller, Carol Price, Ron Sumner, Sandy Soliday, Dan Bergen, Joyce Wall, Don Harmon, Barbara Bickford; Row 2: Floyd Fisher, Wendy White, Steve McCallister, Debbie Durham, Buddy McNiece, Susan Scott, Dennis Bunting, Paula Prater, Tim Hegg, Connie Anderson; Row 3: Dave Romaine, Rosalie Howard, John Thomas, Debbie Banks, Dave True, Carol Mattison, Dave Nelson, Becki Chandes, Dan Estes; Row 4: Ron Bechtel, Ruth Coombs, Dan Hensen, Georgeanna Axiotis, Steve Lantz, Cindy Mally, Lee Griffeth, Rita Gast, Rod Steere, Marleah Namy, Jerry Grayson, Jean Taylor, Charlie Sheppard.

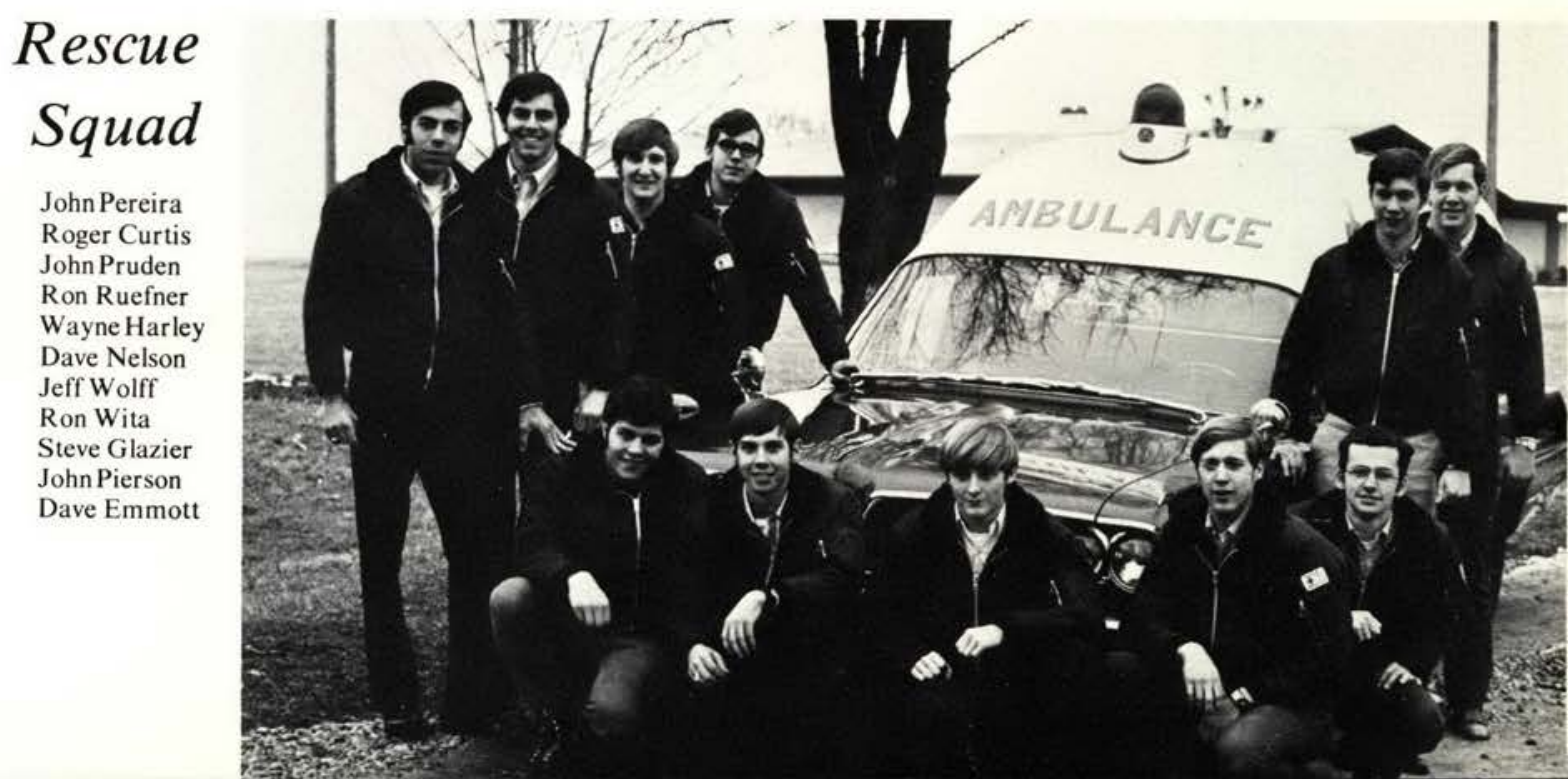




\section{Track}

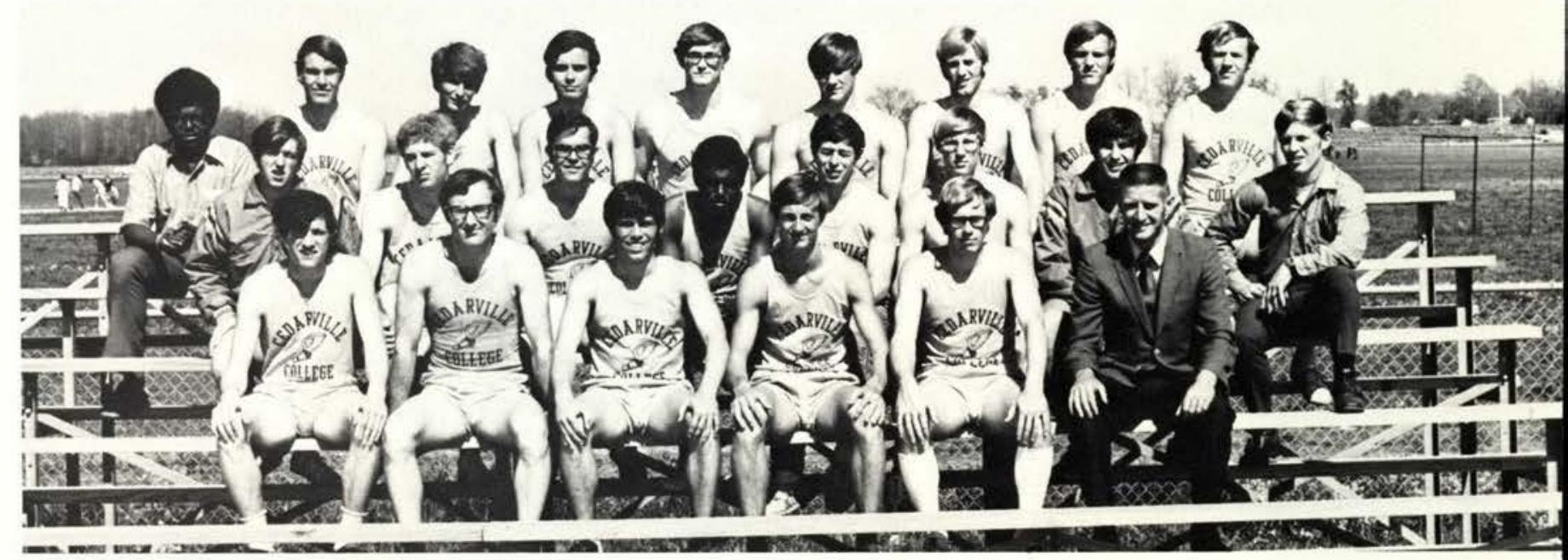

Row I: Jim Chambers, Phil Stine, Steve Gruber, Barrett Luketic, Tim McDonald, Coach King; Row 2: Clinton Eichelberger, Mark Green, Ralph Perkins, Mark Alexander, Bill Bacheller, Jacob Tipton; Row 3: Jerry Gilyard, Andy Cole, Ernie Welborn, Dave Jewell, Dave Globig, Don Johnson, Dan Hensen, Lee Eck, Phil Moon.

Findlay

Bluffton

N. Kentucky State

Bluffton

Urbana

Ohio Northern

Marion

Defiance

Rio Grande
THEY

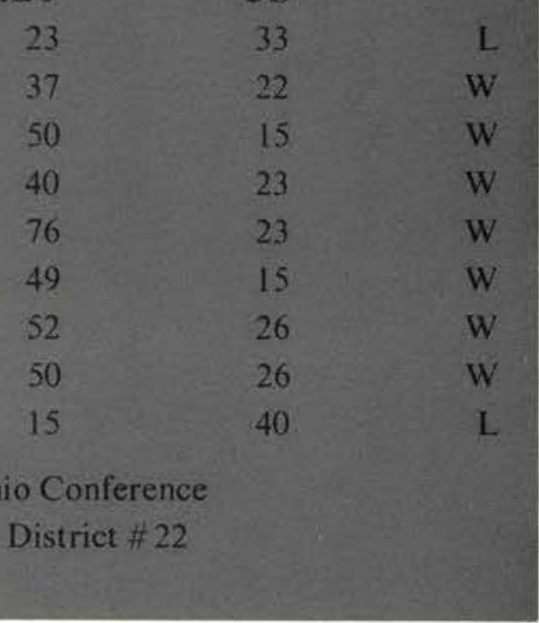

Mark Green

Phil Stine

Barrett Luketic

Tim McDonald

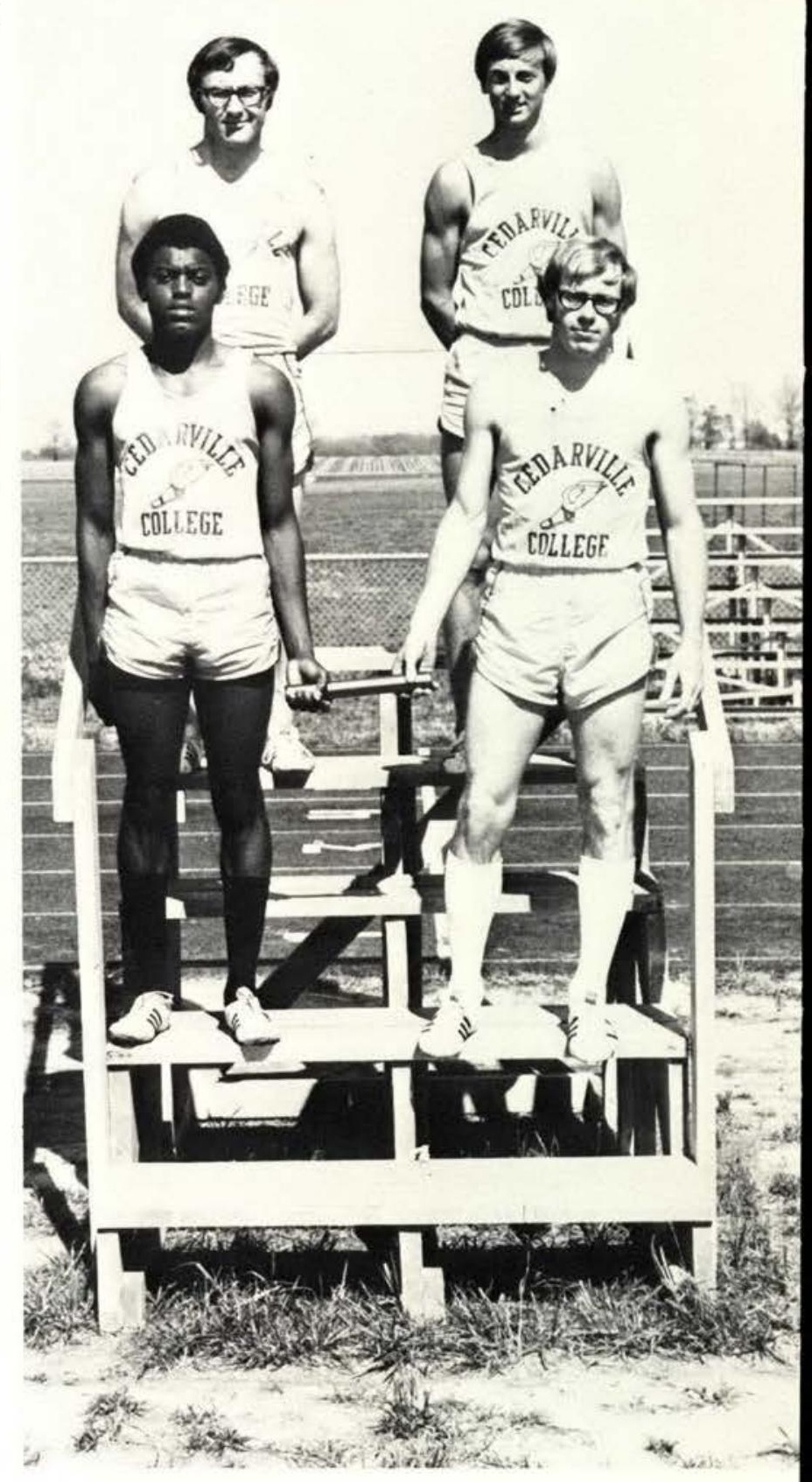

$3 \mathrm{rd}$ in Mid-Ohio Conference

4 th in NAIA District \# 22 

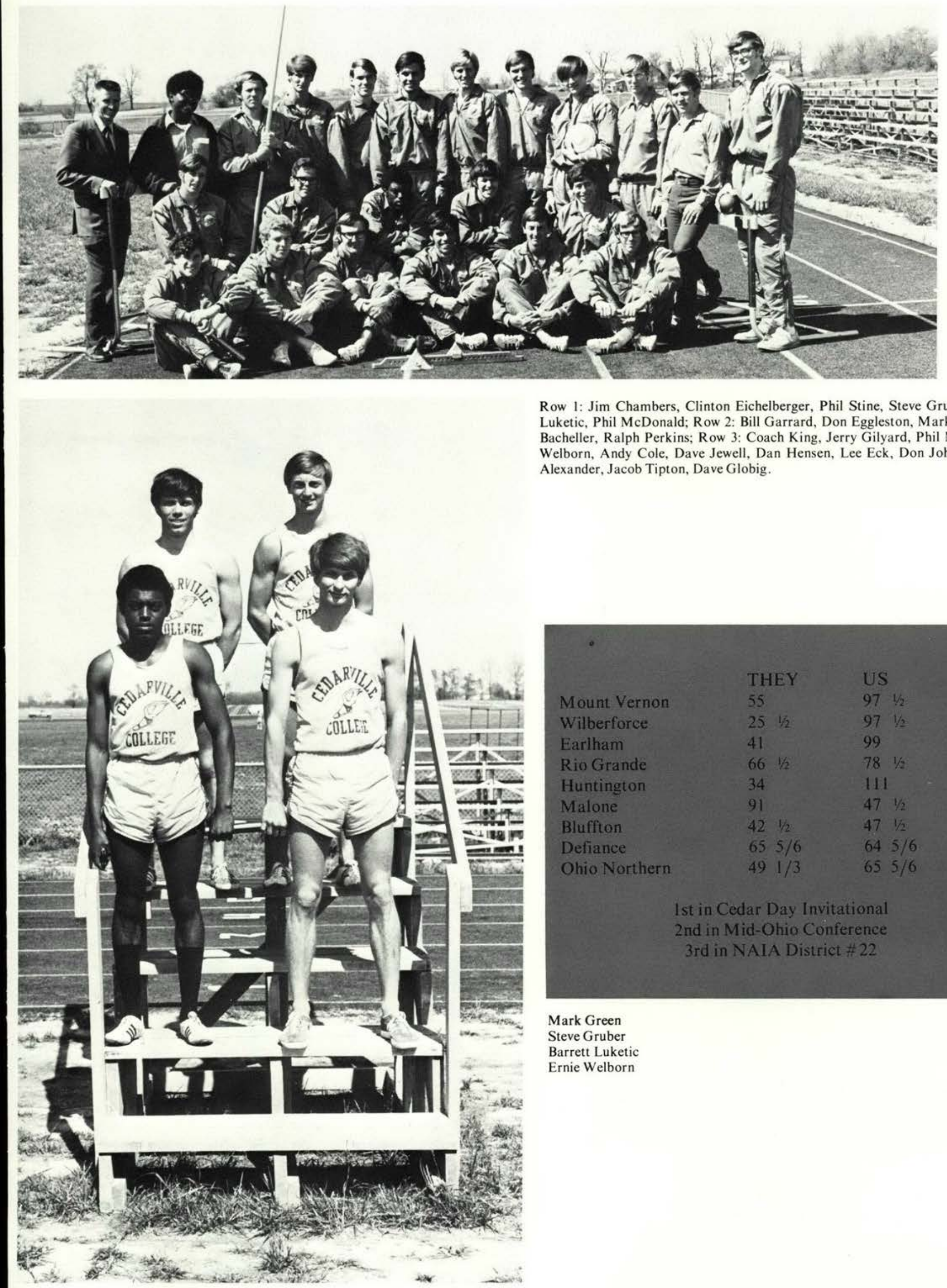

Row 1: Jim Chambers, Clinton Eichelberger, Phil Stine, Steve Gruber, Barrett Luketic, Phil McDonald; Row 2: Bill Garrard, Don Eggleston, Mark Green, Bill Bacheller, Ralph Perkins; Row 3: Coach King, Jerry Gilyard, Phil Moon, Ernie Welborn, Andy Cole, Dave Jewell, Dan Hensen, Lee Eck, Don Johnson, Mark Alexander, Jacob Tipton, Dave Globig.

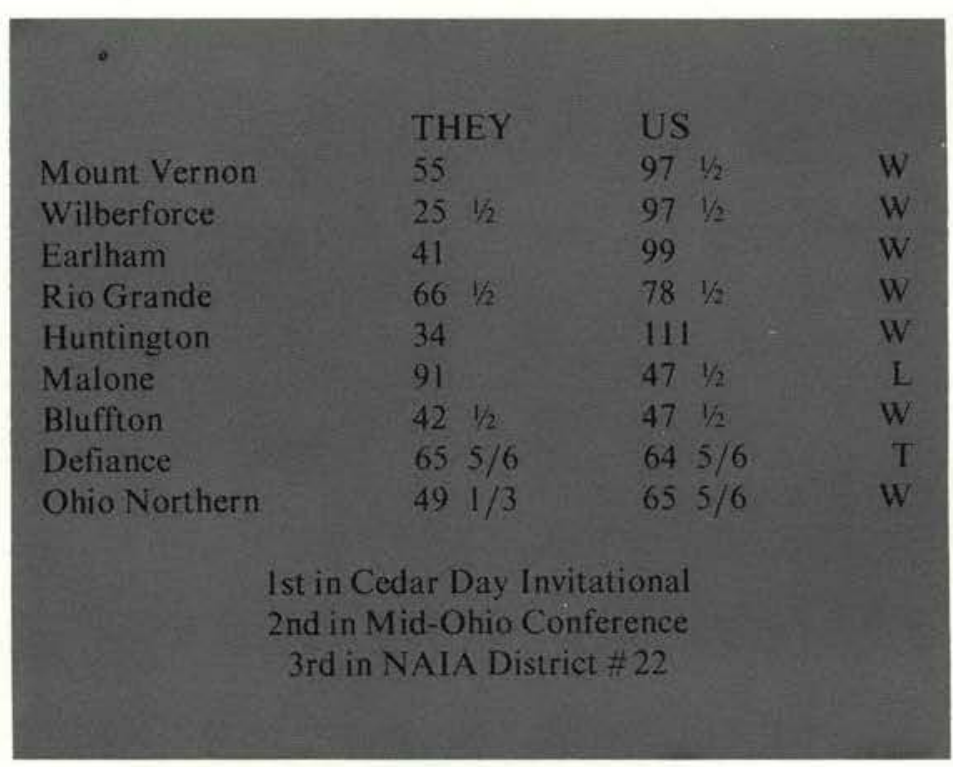

Mark Green

Steve Gruber

Barrett Luketic

Ernie Welborn 


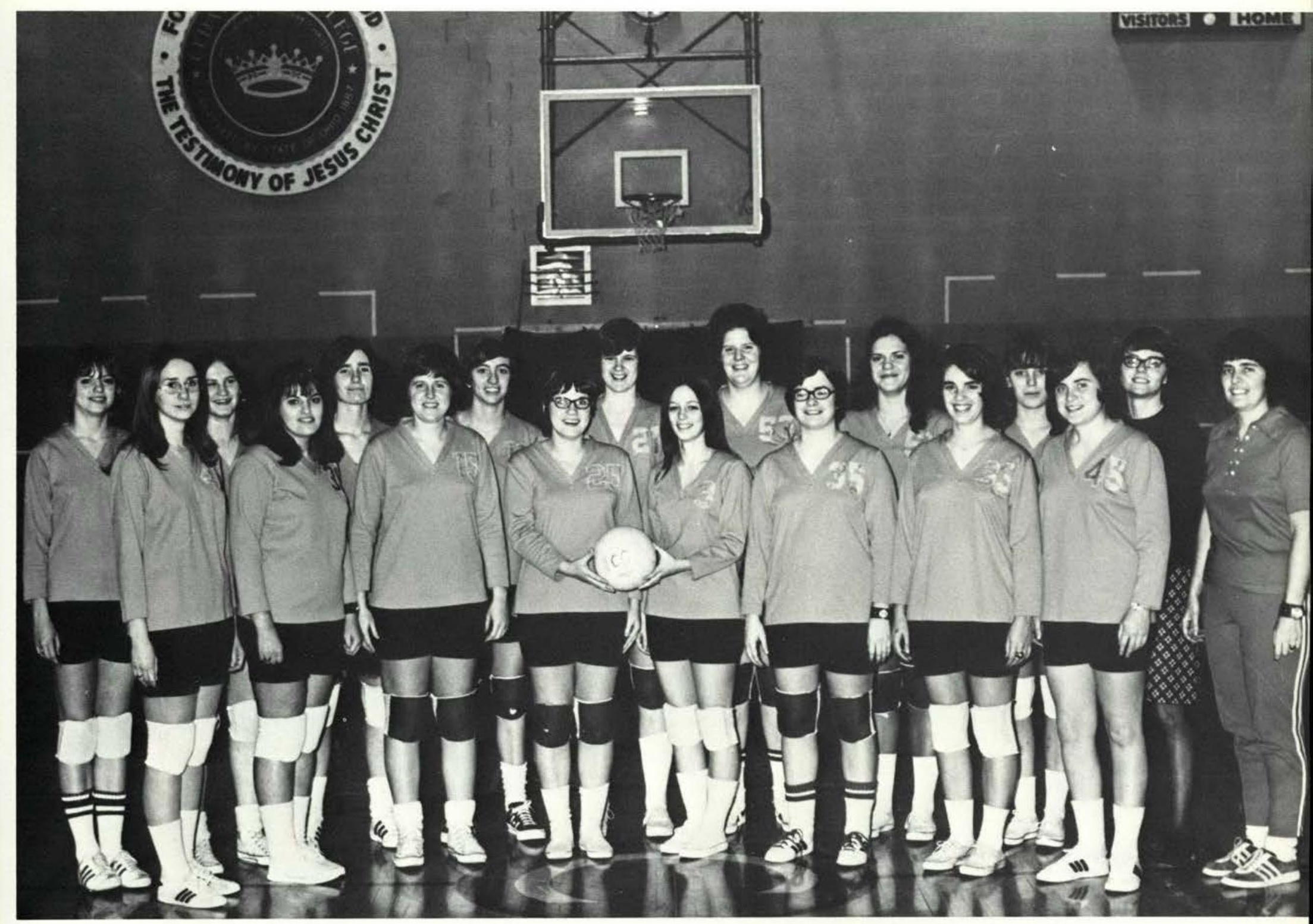

Sandy Holwerda, Nancy Cleckner, Sandy Finch, Brenda Tompkins, Linda Osborne, Linda White, Sally Orihood, Elaine Klanbach, Jan Martin, Theresa Cooper, Karen DeMars, Pam Branning, Cheryl Heslep, Debbie Davis, Chris Tompkins, Bev Pestel, Connie Pumpelly, Miss Kearney.

Volleyball 


\section{Baseball}

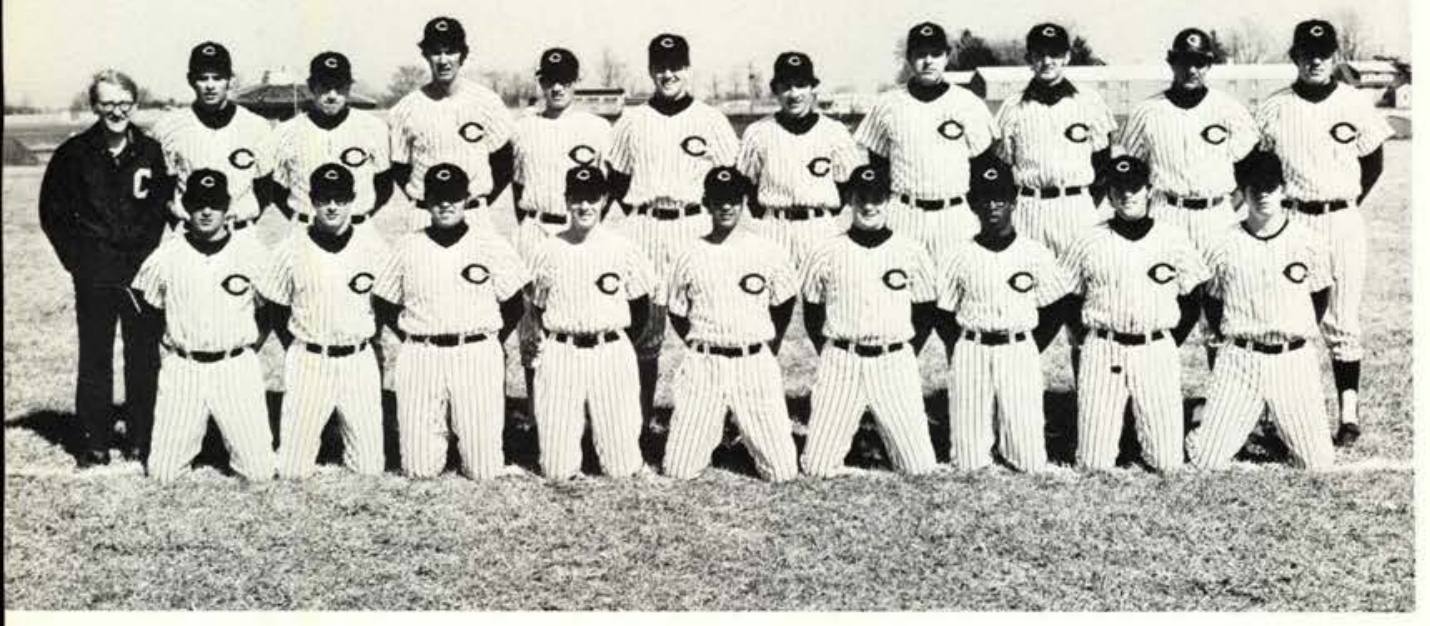

Row 1: Ray Warwick, Rodney Hanson, Wayne Williams, Jack Browning, David Rodriguez, Jerry Griswold, Clancy Parker, Paul Allen, Buddy McNiece; Row 2: Doug Burkhard, Dennis Lowstetter, Tom Knowles, David Webber, Dan Inghram, Paul Strychawski, Lynn Howard, David Grant, Sam Cimilucca, Coach Berry.
THEY US

Spring Hill $\quad 4 \quad 2$

Spring Hill

Keesler Air Force Base

Keesler Air Force Base

Livingston University

University of Dayton

Alumini

Ohio Inst. of Technology

Wright State

N. Kentucky State

N. Kentucky State

Urbana

Urbana

Xavier University

Central State

Wilmington

Ohio State Jr. Varsity

Malone

Malone

Ohio State Jr. Varsity

Ohio State Jr. Varsity

Wright State

Rio Grande

Rio Grande

Earlham

Earlham

Mt. Vernon Nazarene

Ohio Dominican

Ohio Dominican

Central State

0

8

Central State 

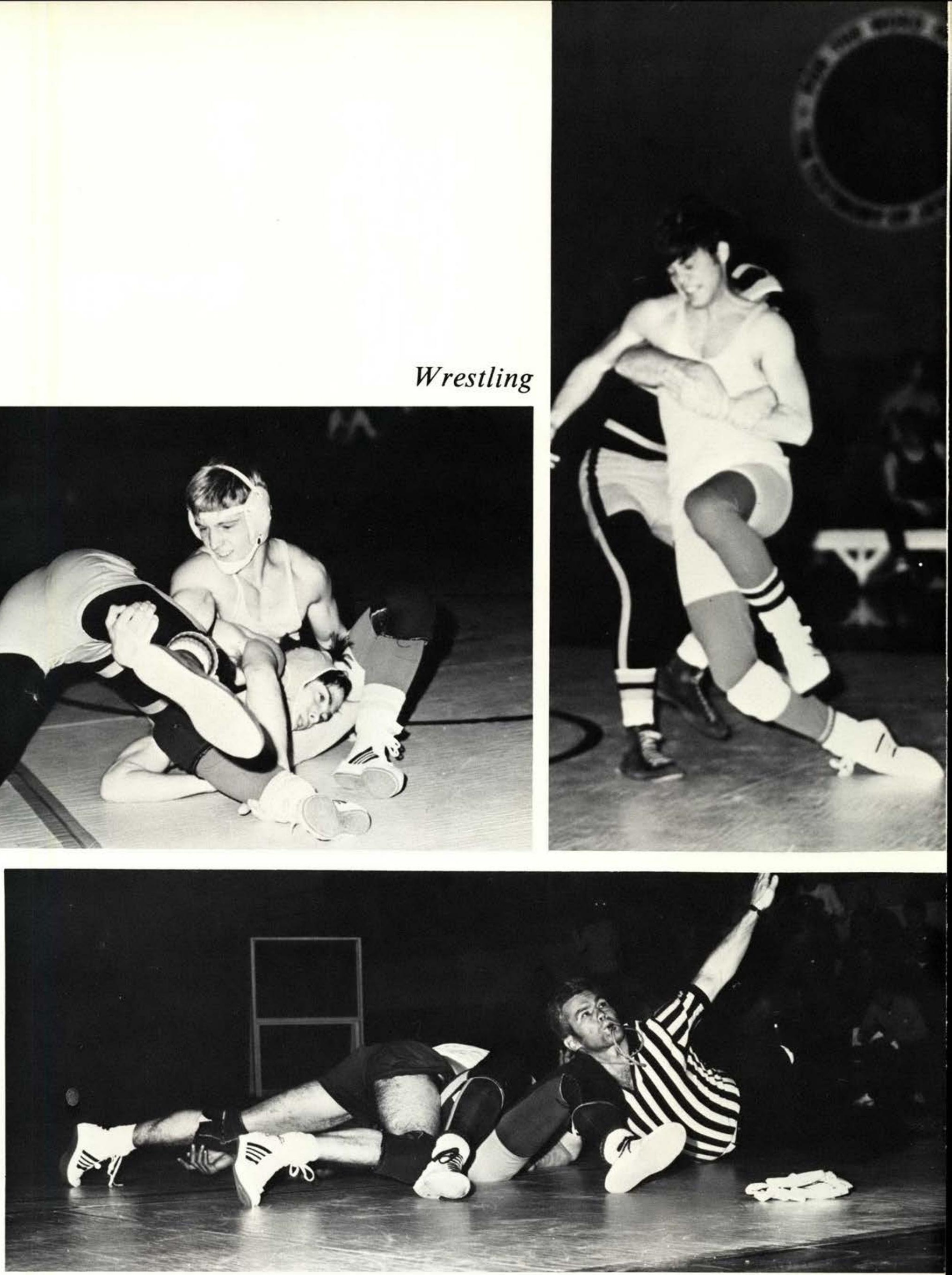


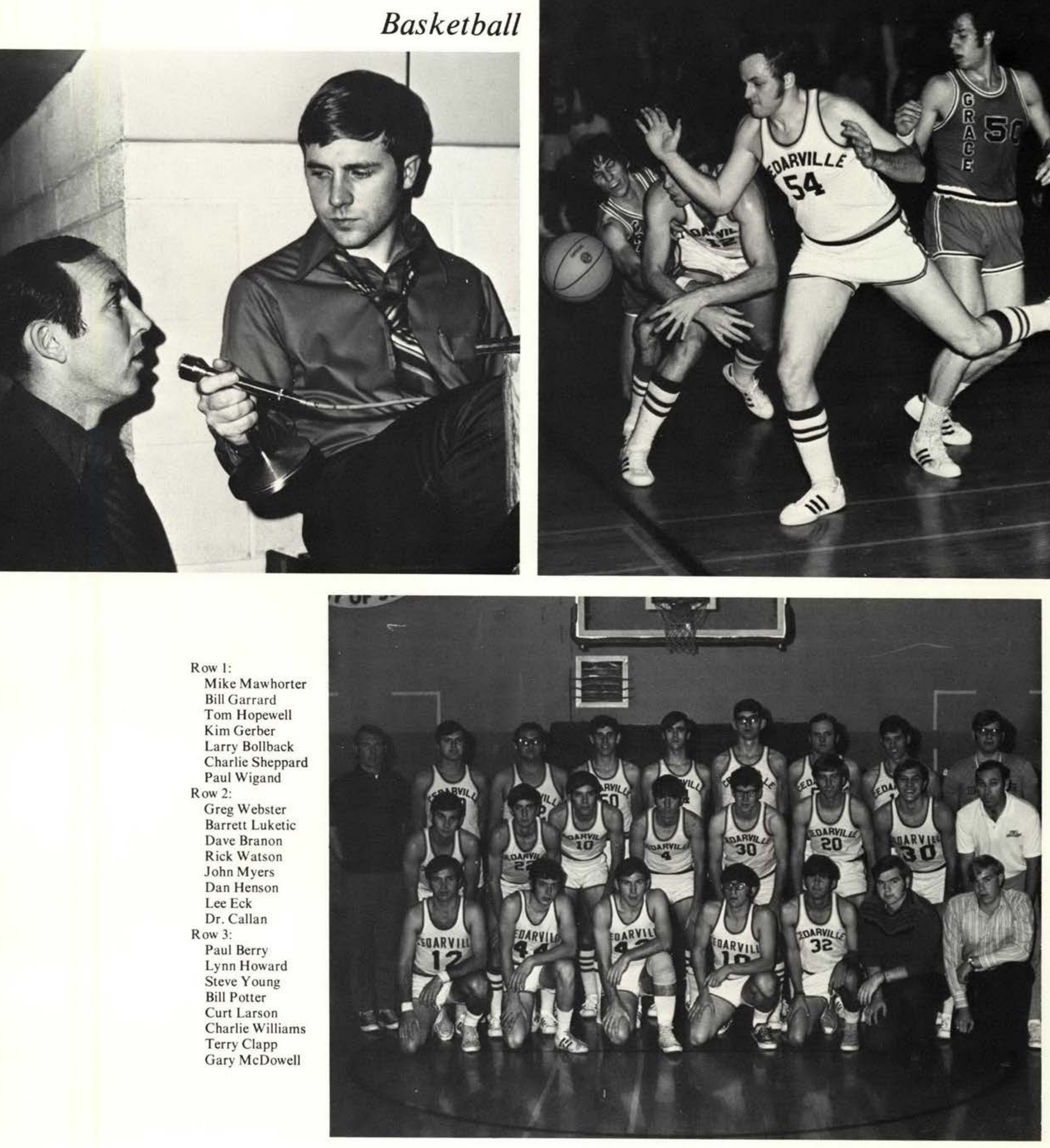




\begin{tabular}{|c|c|c|}
\hline & THEY & US \\
\hline Spring Arbor & 89 & 80 \\
\hline Manchester & 78 & 80 \\
\hline Trinity Christian & 87 & 85 \\
\hline Rio Grande & 105 & 71 \\
\hline Urbana & 106 & 78 \\
\hline Wilberforce & 79 & 98 \\
\hline Marion & 109 & 88 \\
\hline Ohio Dominican & 91 & 90 \\
\hline Wilmington & 90 & 66 \\
\hline Defiance & 109 & 80 \\
\hline Wright State & 85 & 77 \\
\hline Bluffton & 91 & 74 \\
\hline Walsh & 77 & 73 \\
\hline Central State & 88 & 89 \\
\hline Findlay & 110 & 66 \\
\hline Wilberforce & 86 & 84 \\
\hline Urbana & 86 & 66 \\
\hline Ohio Dominican & 77 & 79 \\
\hline Malone & 92 & 73 \\
\hline Marion & 81 & 85 \\
\hline Rio Grande & 85 & 72 \\
\hline Bluffton & 104 & 88 \\
\hline Wilmington & 87 & 73 \\
\hline Grace & 84 & 93 \\
\hline Malone & 107 & 84 \\
\hline
\end{tabular}
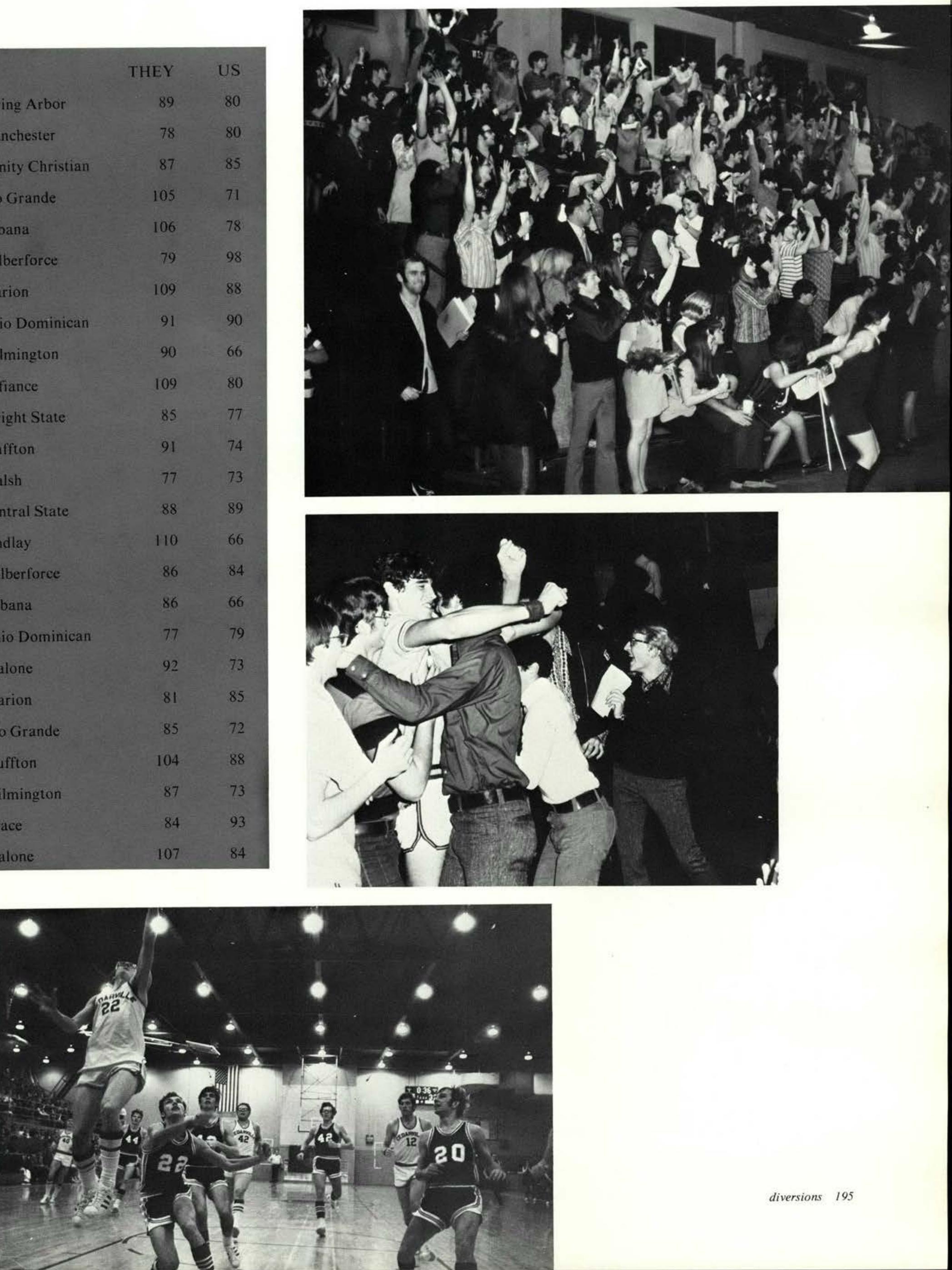


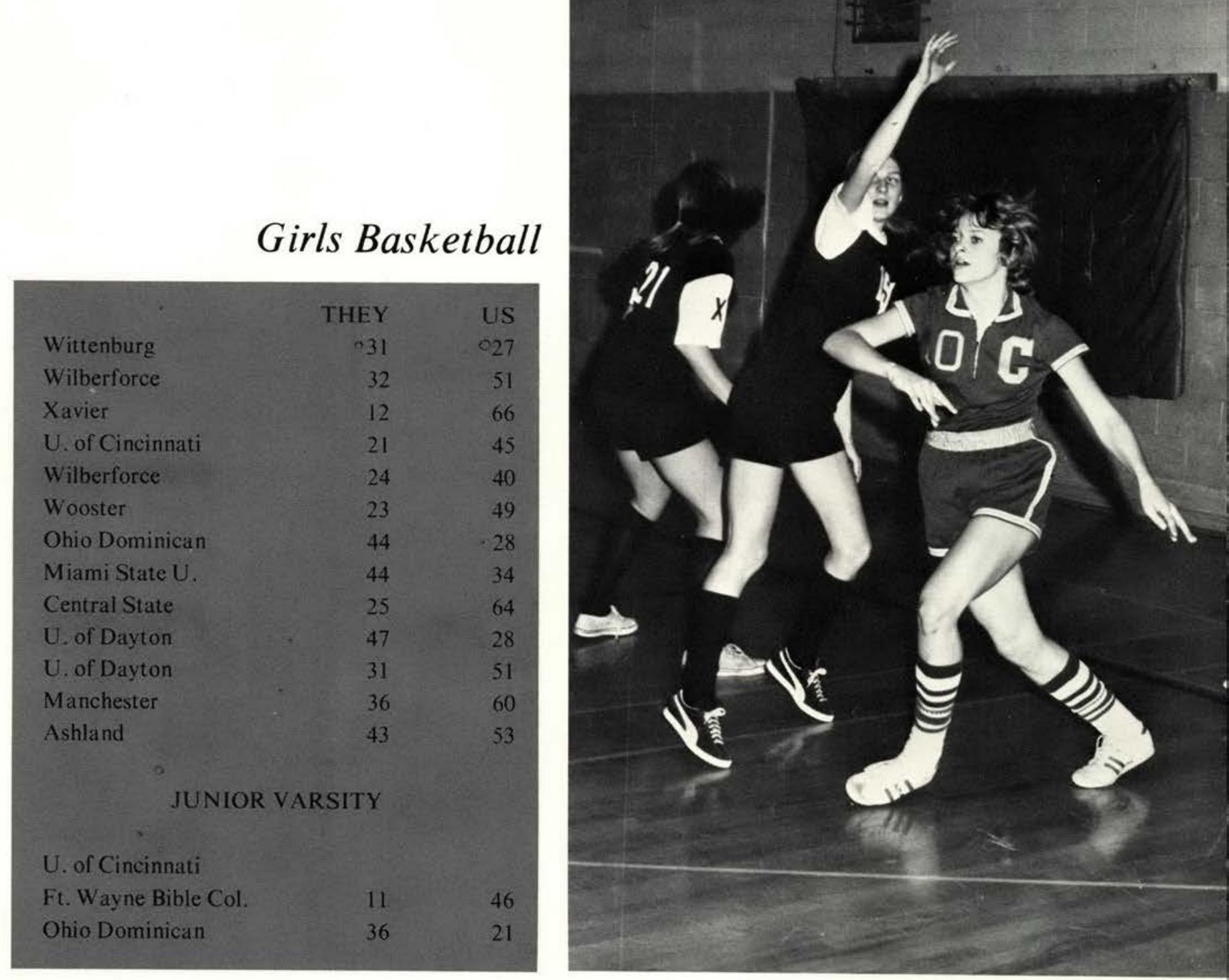

Row 1: Sandy Holwerda, Roberta Lutton, Sally Orihood, Connie Pumpelly, Landra Grant, Elaine Kalnbach; Row 2: Rita Gast, Jean Taylor, Karen DeMars, Jan Martin, MaryAnn Frauenknecht, Bev Pestel, Miss Jeremiah.

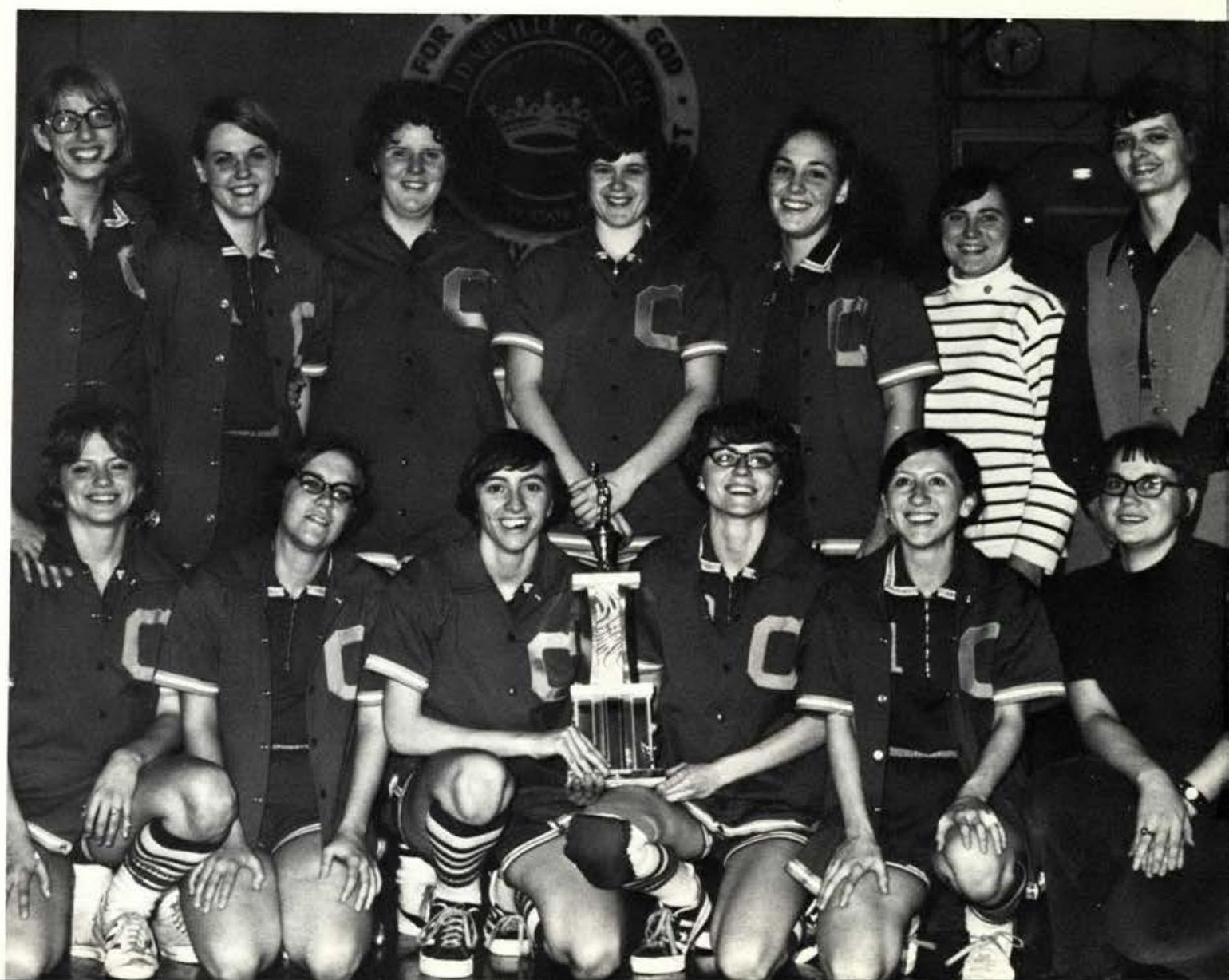




\section{P.E.M.M.}

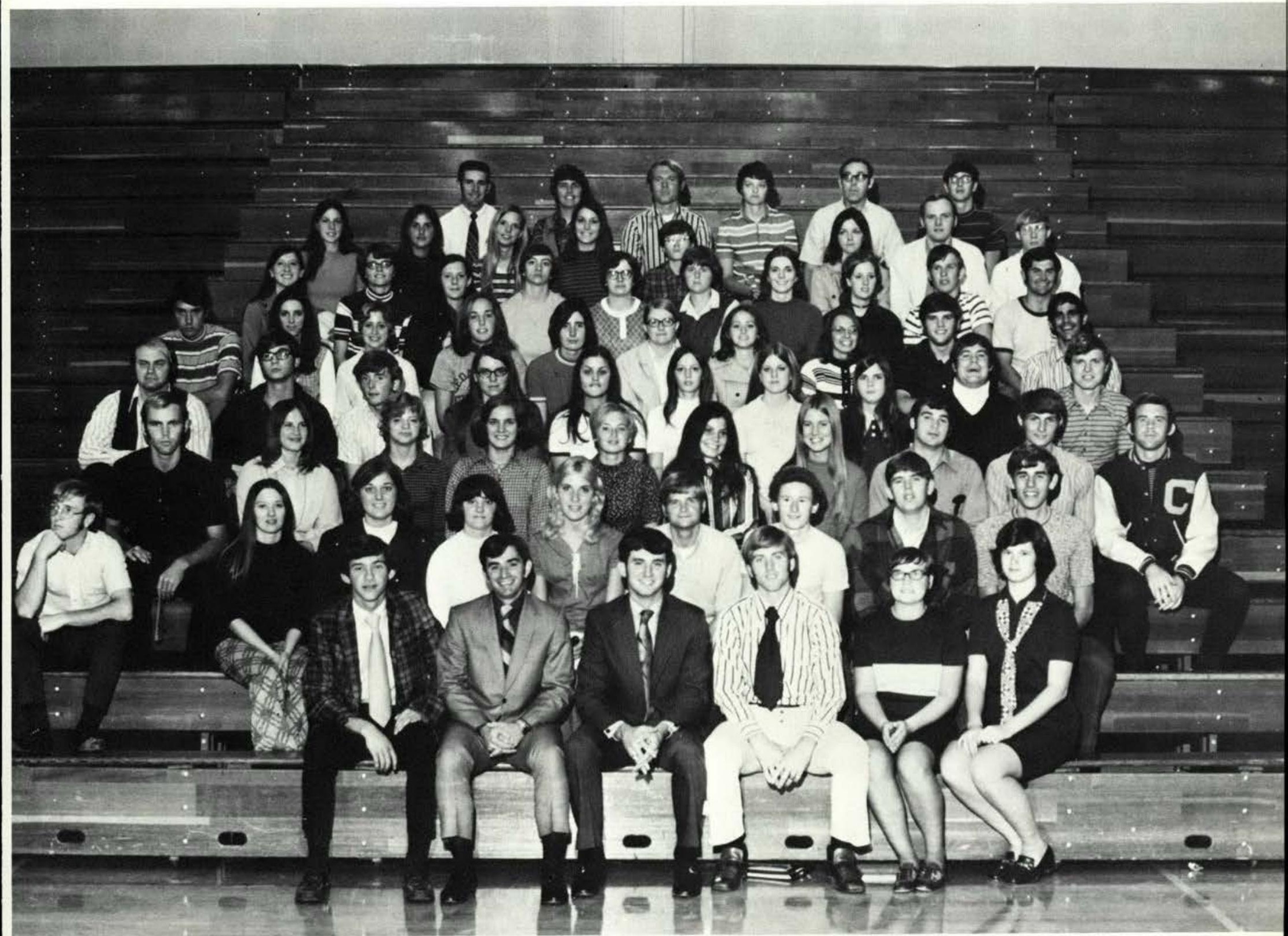

Row 1: Paul Strychalski, Jon Jenney, David Grant, Dan Henson, Elaine Kalnbach, Janice Martin; Row 2: Mike Mays, Rose Bishop, Denise Edwards, Joyce Byers, Mindy Graf, Jeff Callegher, Mark Hunter, Cody Vincent, Steve Young; Row 3: David Eller, Sandy Finch, Sandy Holwerda, Sue Preston, Marsha Saw icki, Sally Miller, Doris Johnson, Ray Warwick, Ernie Welborn, Phil Moon; Row 4: Richard Rose, Randy Walter, Mark Carpenter, Cheryl Cressman, Janine Spears, Theresa Cooper, Vicki Huddleston, Joy Belle Erickson, Dennis Bunting, Lynn Howard; Row 5: Tom Knowles, Joy Owenby, Jenny O'Neill, Mary Ann Fraunknecht, Linda Osborn, Joy Tate, Leslie Leapline, Becky Imbro, Paul Allen, David Rodriguez; R ow 6: Landra Grant, Connie Pumpelly, Ann Good, Sally Orihood, Pam Branning, Linda White, Linda Orihood, Kathy Frields, Jacob Tipton, Tom Kovacik; Row 7: Charlotte Ruffin, Karen Syphers, Karyn Peterson, Sue Parker, Carol Jo Mains, Leslie Good, Charlie Williams, Mark Alexander; Row 8: Coach King, Miss Kearney, Coach Berry, Miss Jeremiah, Coach Callan, Rodney Hansen. 
THEY US

Earlham

Wright State

19

Sinclair

Central State

Wilmington

Central State

0

20

Ohio Dominican

Defiance

Bluffton

Urbana

Rio Grande

Urbana

John Myers Andy Amos

Steve Herman Tim Greenwood John Thomas Tom Strong Jeb Beachum Russ Damus

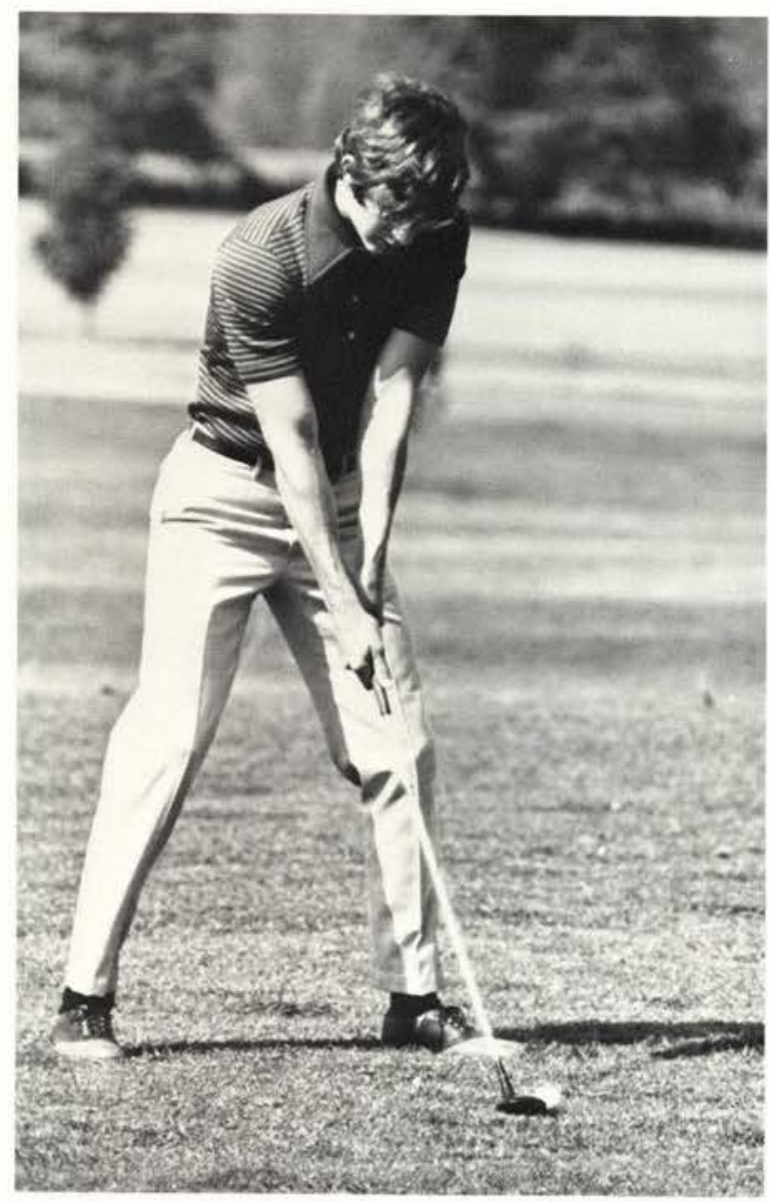

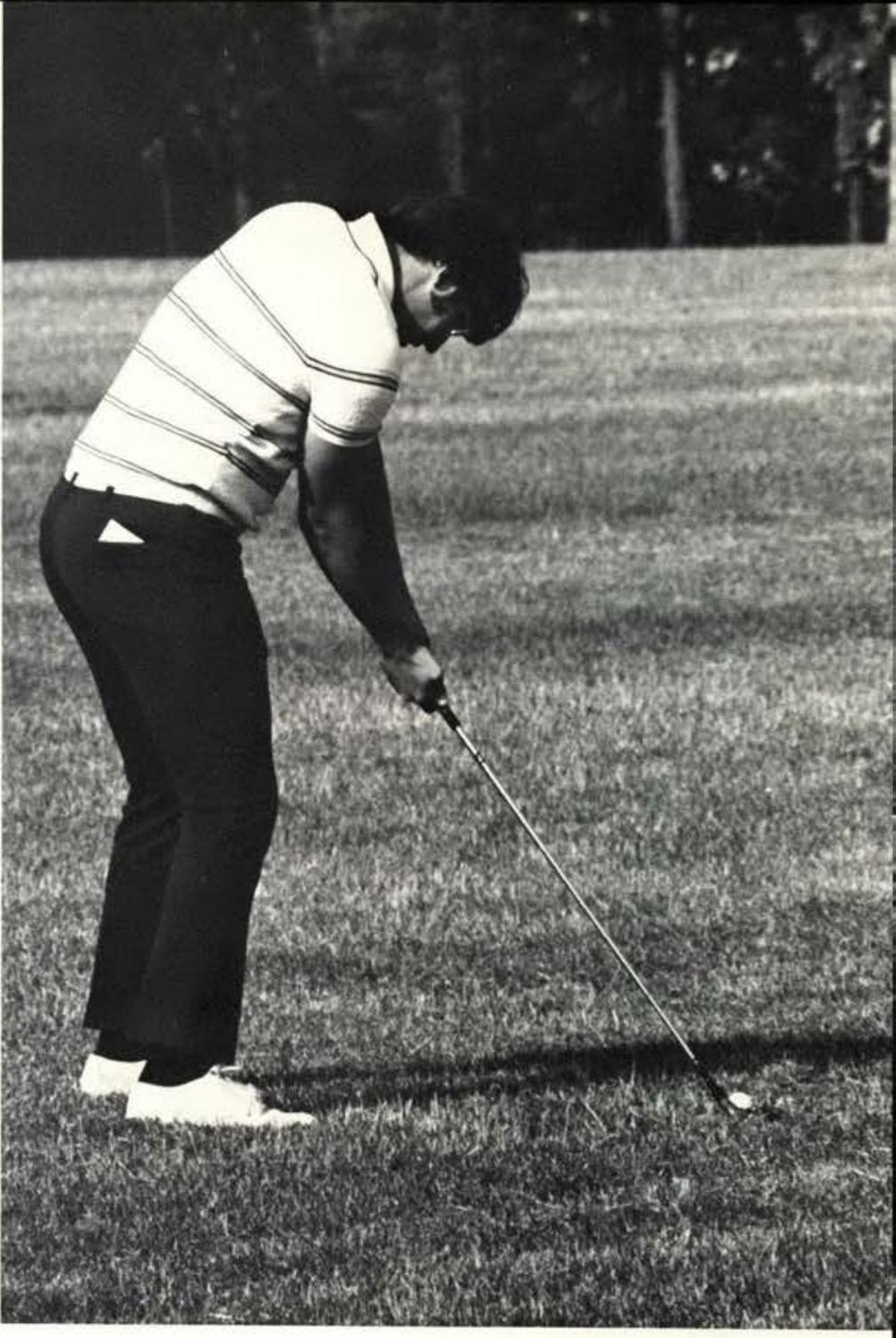

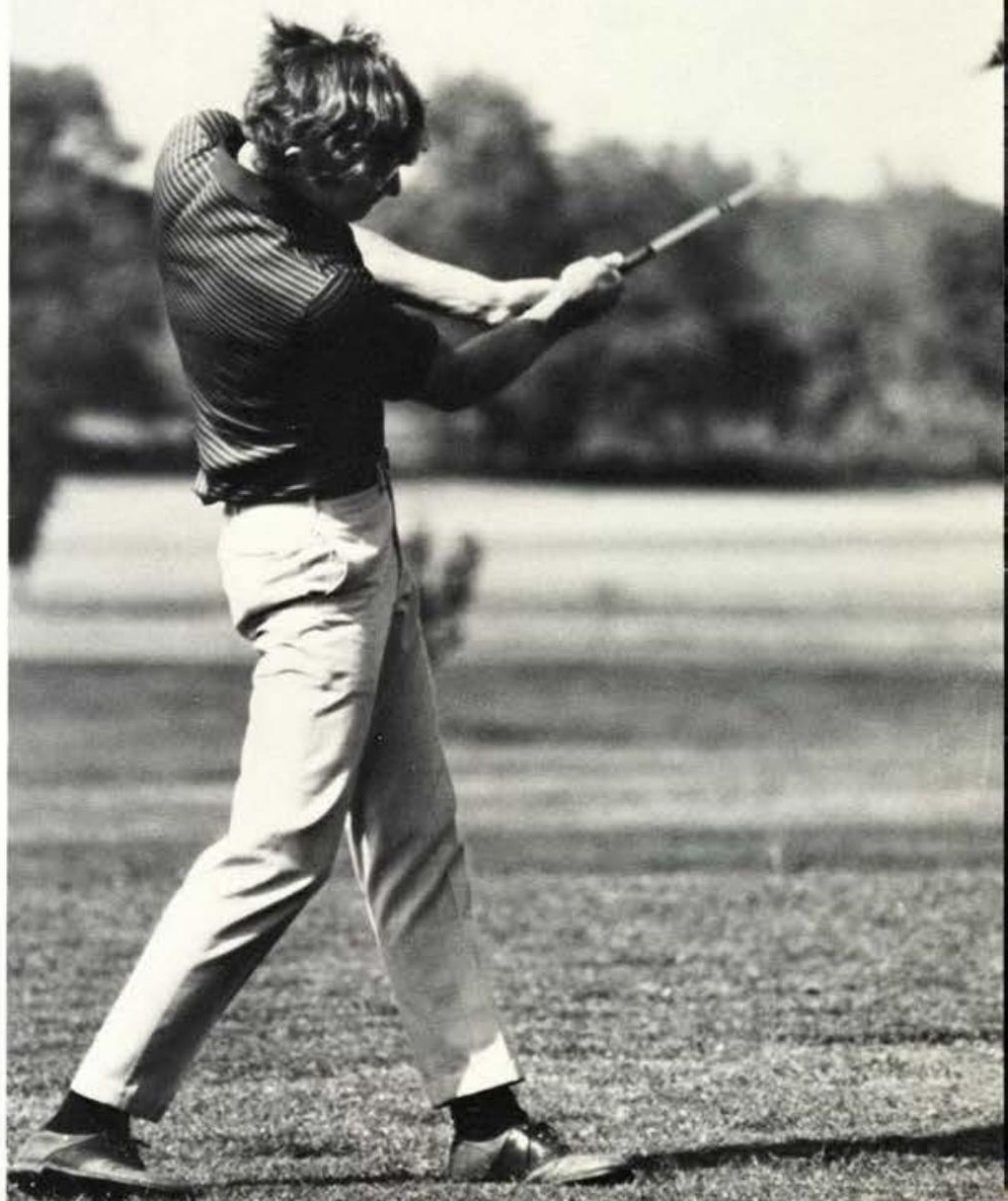

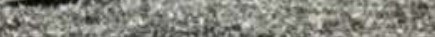





\section{Varsity " C"'}

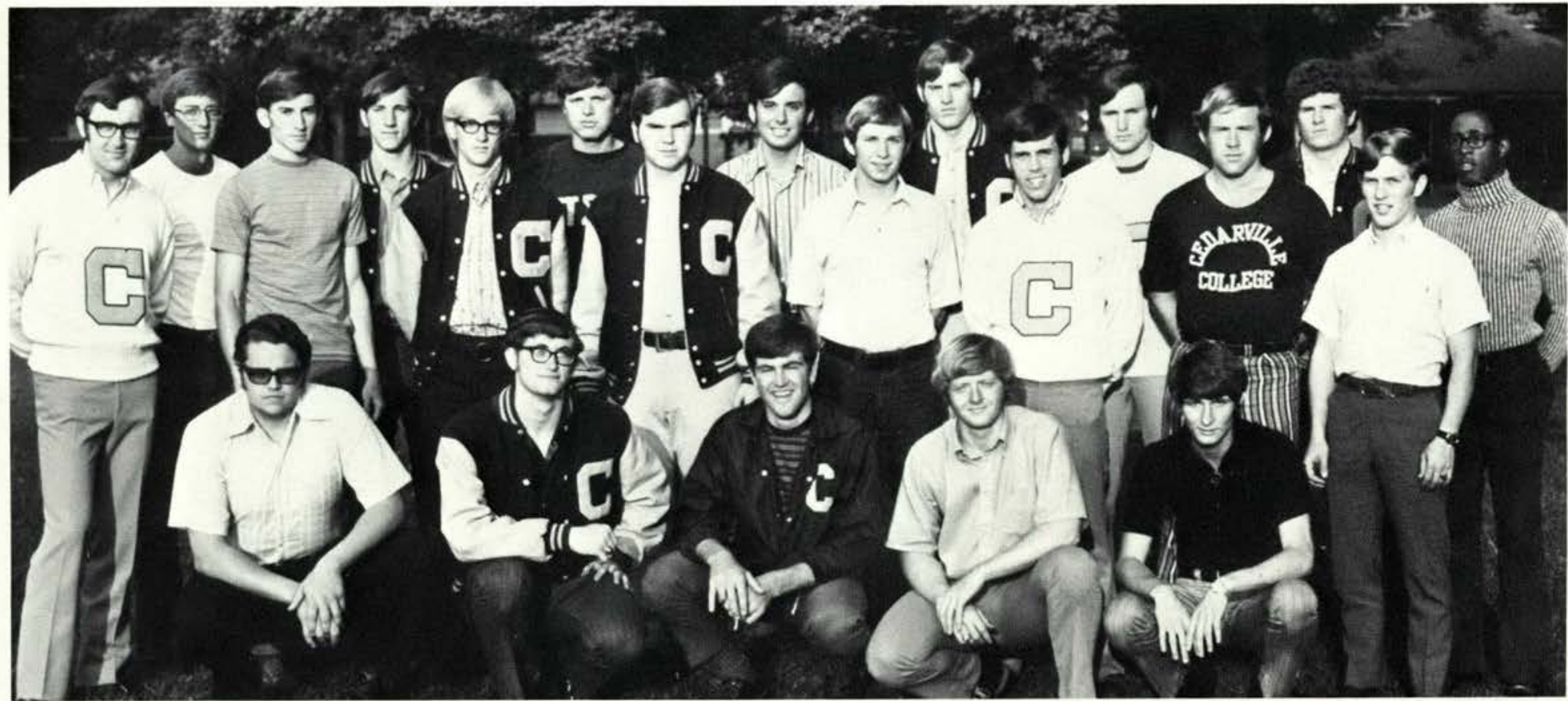

Kneeling: John Harrison, Dave Globig, Dan Inghram, Jeff Woodcock, Ernie Welborn; Row 1: Phil Stine, Tom Farlow, Dave VanDorf, Charles Sheppard, Jim Greening. Steve Gruber, Phil Moon, Jacob Tipton: Row 2: Barrett Luketic, Bill Tobias, Lynn Howard, Dave Jewell, Terry Clapp, Warren Jenkins, Steve Francis, Clarence Parker.

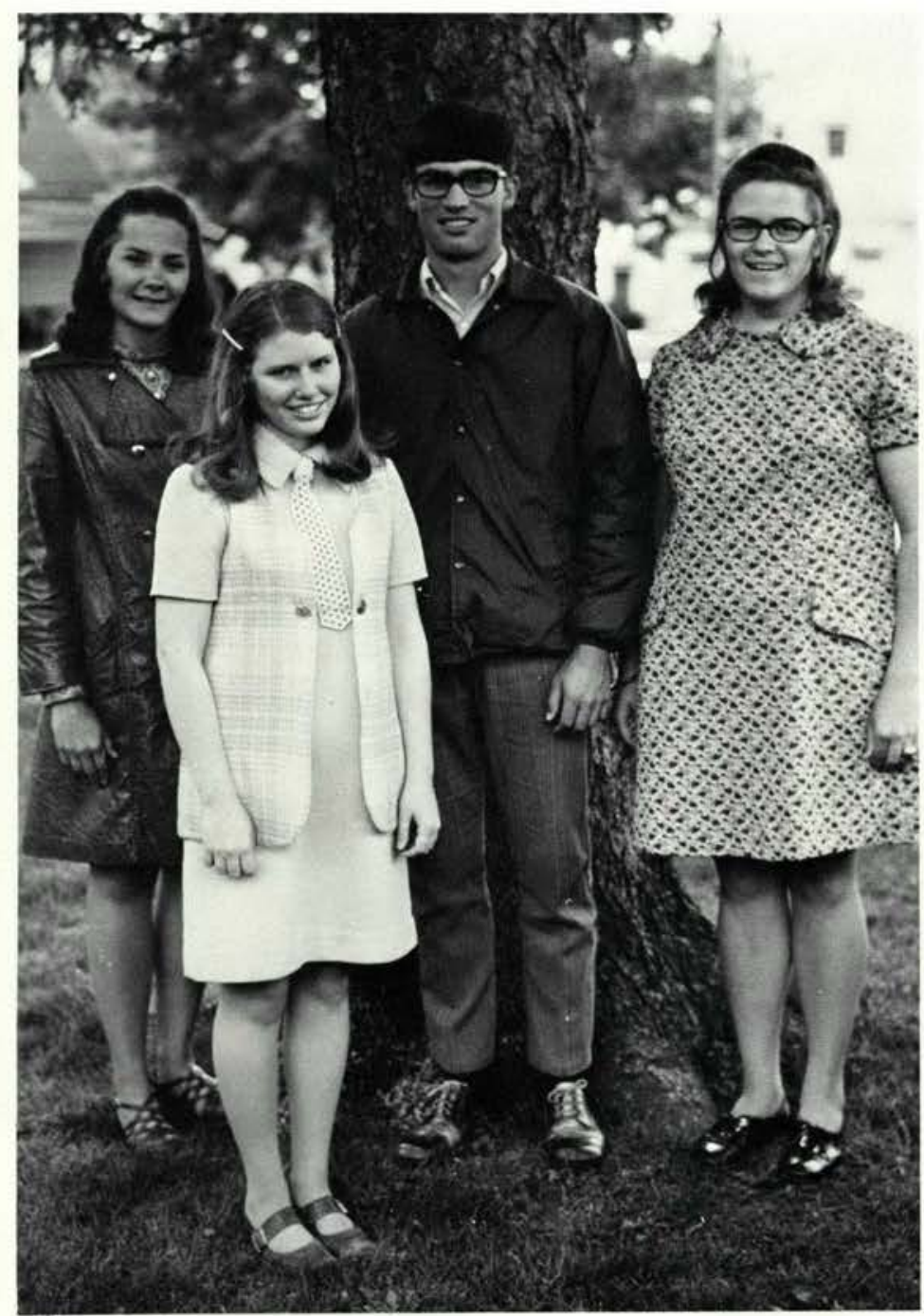

\section{Phi Delta}

\section{Janet Hillery}

Sue Seldon

David Webber

Phyllis Carey

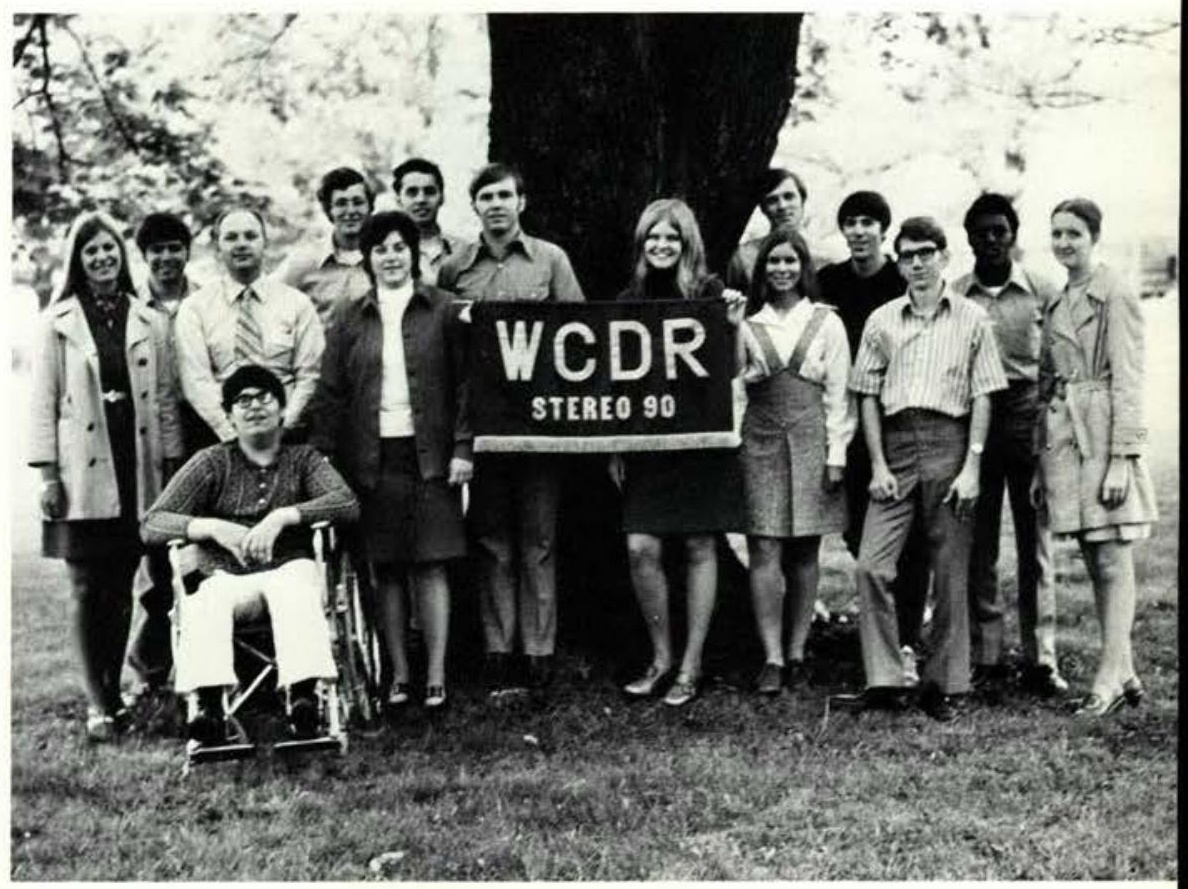

$W C D R$

$\begin{array}{ll}\text { Ruth McCauley } & \text { Molly Rehn } \\ \text { Rick McIntosh } & \text { Mary Glenn } \\ \text { Mr. Paul Gathany } & \text { Ron Clarke } \\ \text { Floyd Fisher } & \text { Don Fleming } \\ \text { Wayne Shepherd } & \text { Jeff St. Clair } \\ \text { Merla Hammack } & \text { Mark Green } \\ \text { Dave True } & \text { Arlene Knight }\end{array}$

Mike Mawhorter 


\section{Personnel Assistants}

Becky Anderson, Rex Rogers, Virginia Heal, Steve Shank, Elaine Kalnbach, Sherilyn Hansen, John Pereira, Jane Emerson, Becky Canine, Pete Lilbach, Raynelle White, John Harrison, Yvonne Cope, Larry Klemm, Brenda Will, Warren Jenkins, Connie Mach, Dan Stemen, Bill Tobias, Laura Jones, Judy Hepworth, Dave Globig, Sue Saunders, Rae Belle Fisher, Terry Clapp, Sharon Neeley, Andy Amos, Sue Sagendorf, Harvey Howdyshell, Valerie Holfield.

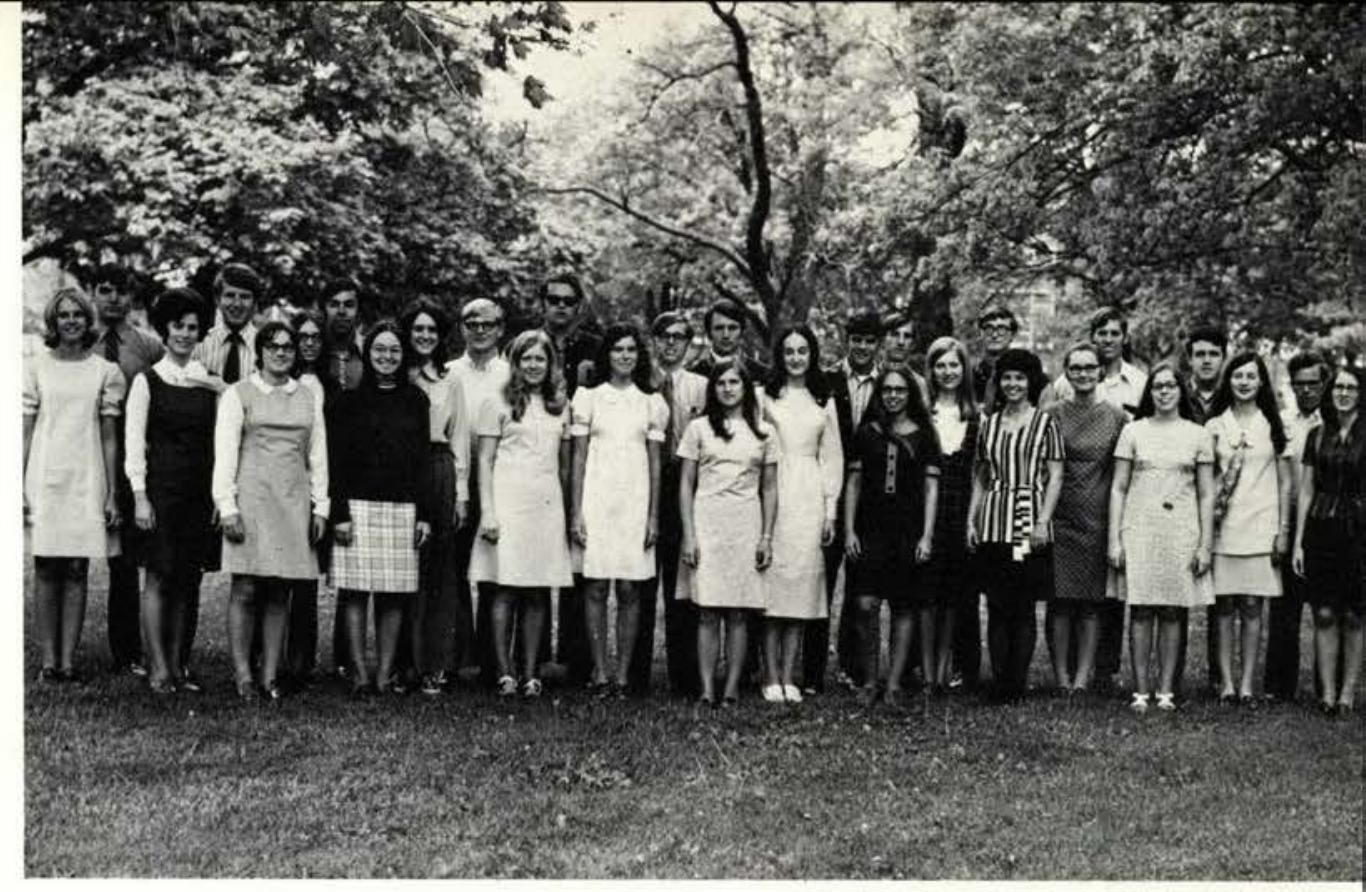

\section{Student Council}

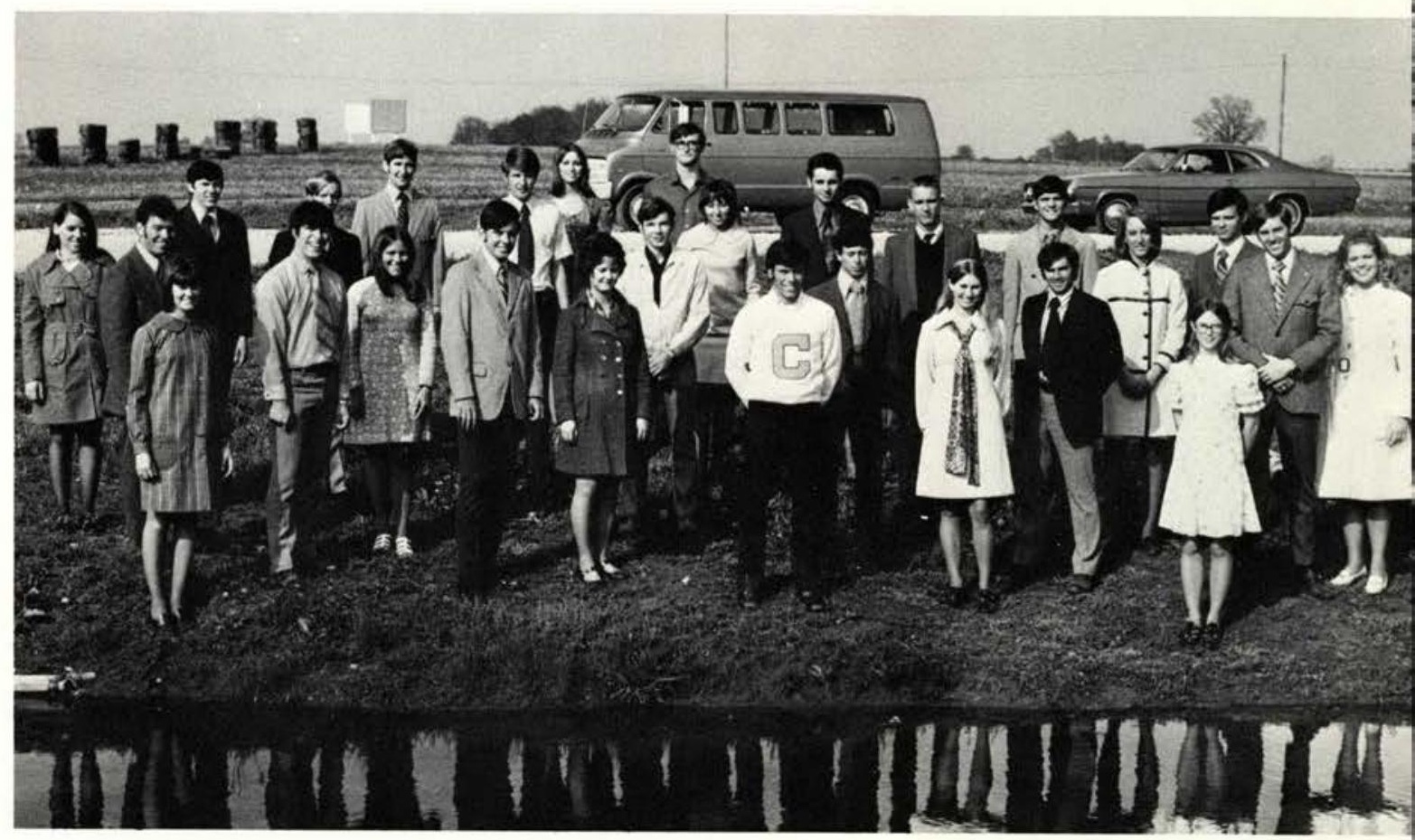

Cheryl Cressman, Mike Wilhite, Sherry Klomparens, John Bratcher, Bob Mahl, Con Cavis, Linda Chute, John Prudence, Dave Jewell, Steve Shank, Georgeanna Axiotis, Bonny Bodenmiller, Dave Price, Dave Globig, Becky Chandis, Steve Gruber, Ralph Perkins, Dave True, Mark Bohland, Sue Scott, John Jenney, Dan Stemen, Julie Jensen, Jeanette Powley, Paul Radcliff, Terry Clapp, Carol Bierbaum.

\section{$M E N C$}

Debbie Holt, Bev Fields, Mary Faust, Darla Stevens, Suzanne Hale, Sharon Reese, Martha Sensensey, Lorraine Bogert, Sheila Rogers.

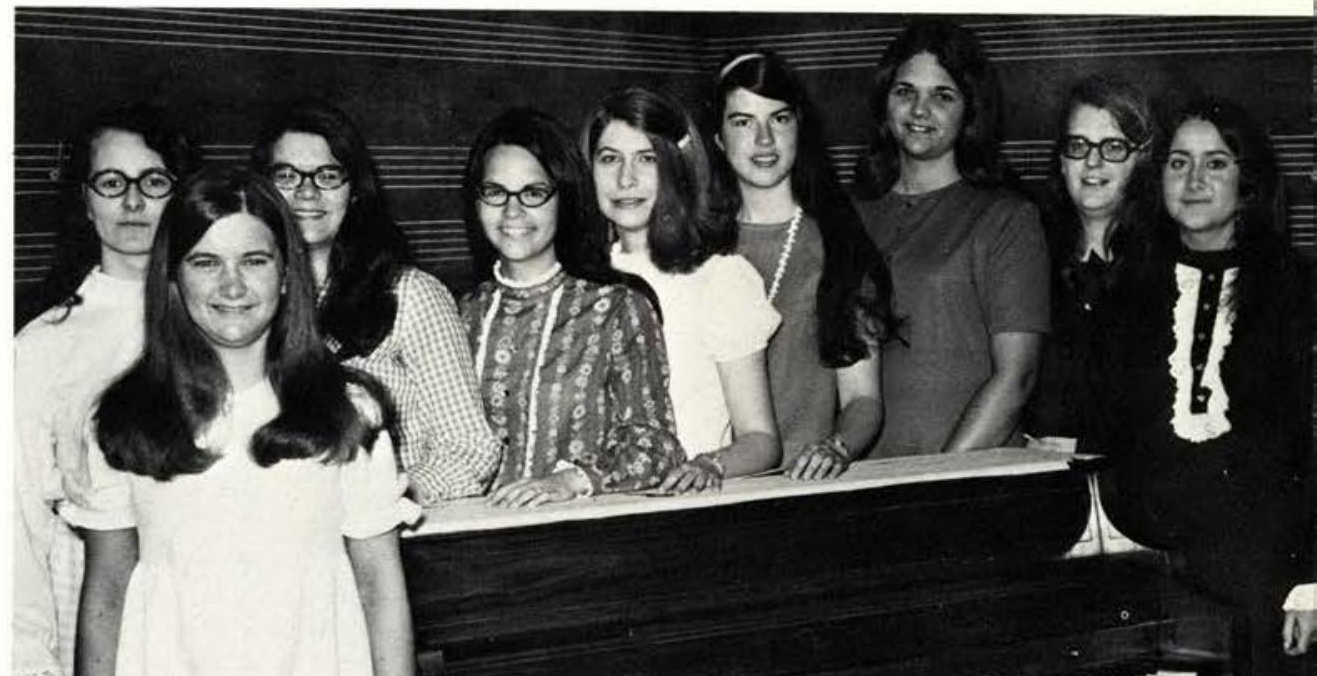




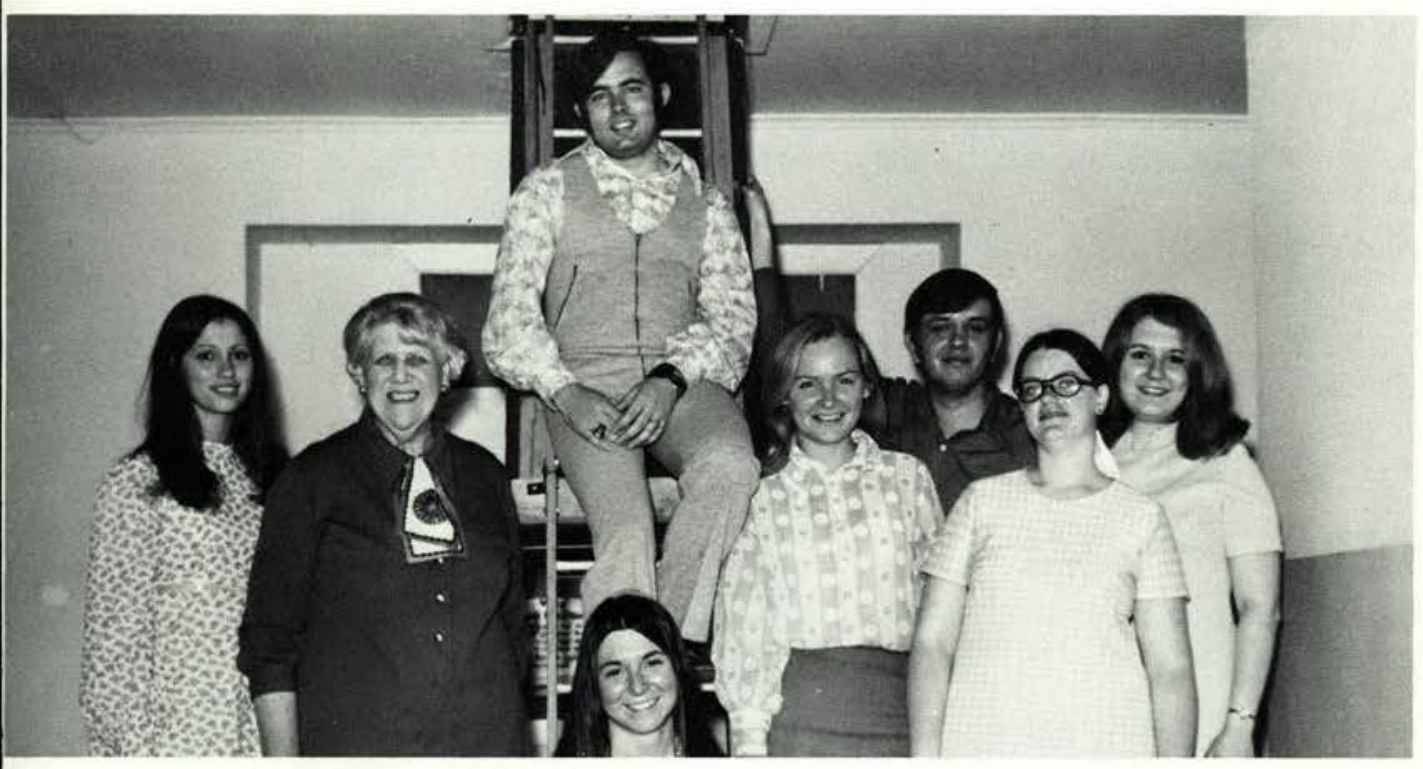

Georgeana Axiotis, Mrs. Maddox, Don Harmon, Laura Lee Grable, Janet Long, Ted Gifford, Judy Johnson, Ruth Coombs.

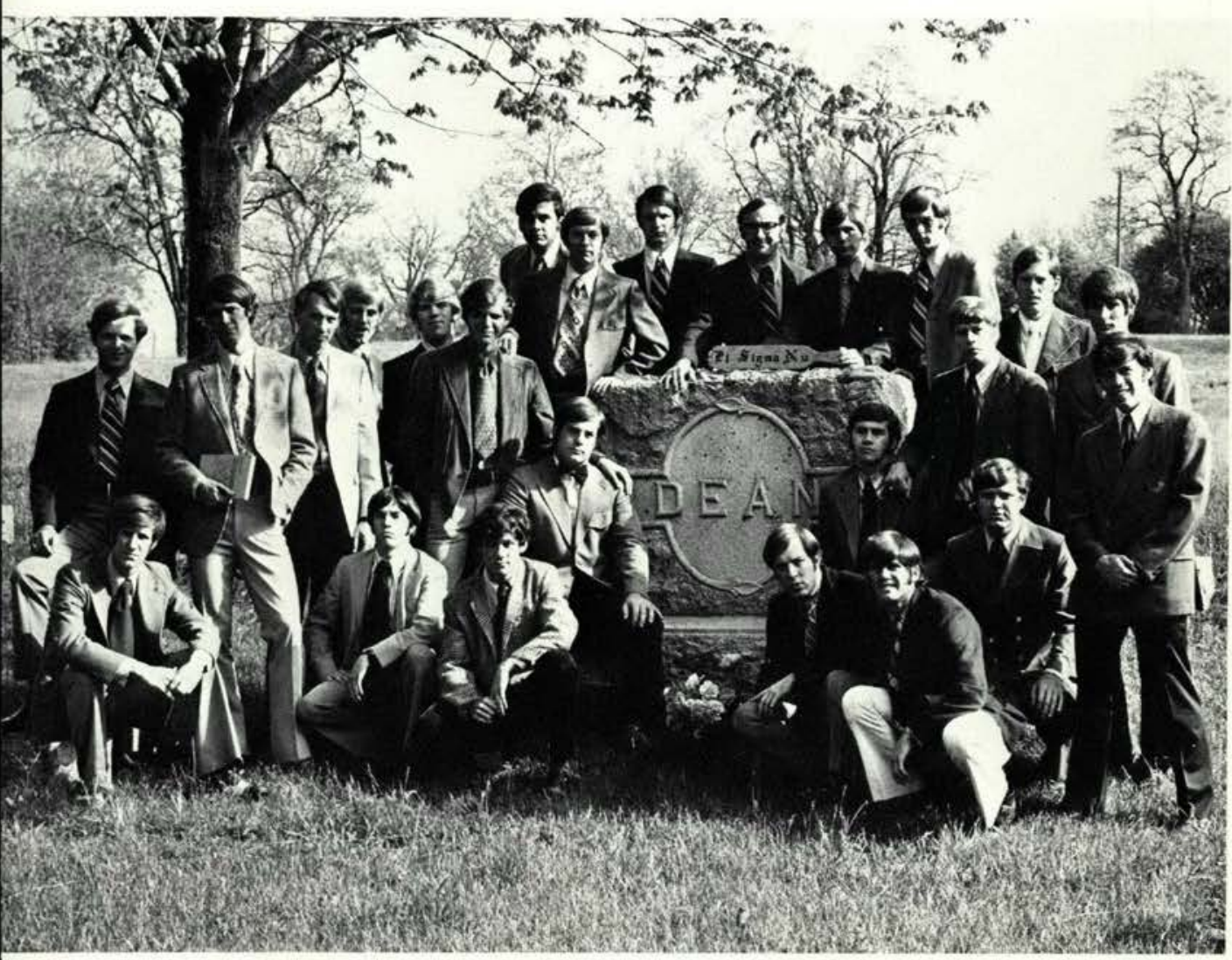

Row 1: Bob Austin, Ron Sumner, Ed Howell, Dennis Bunting, Tim Hegg, Greg Webster, Larry Ballbach, Lyn Howard: Row 2: Doug Hess, Tom Knowles, Randy Erickson, Dan Henson, Bob Ely, Lewis Tewis, Dave Jewell, Jin Greening, Warren Jenkins, Phil Stine, Carl Rogers, Steve Spencer, Buddy McNiece, Terry Clapp, Ernie Welborn, Steve Gruber.

\section{Village Players}

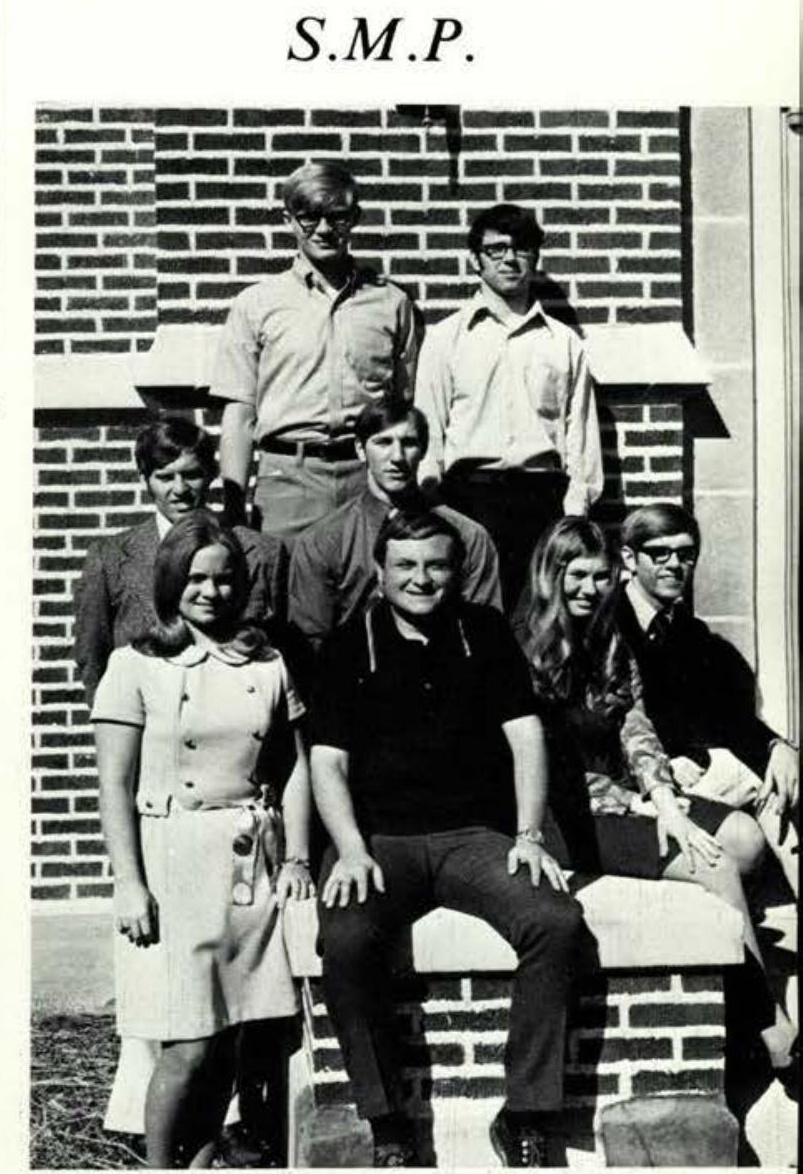

Row 1: Sue Moore, Eric Cuenin, Sue Scott,

Tom Seidler; Row 2: Terry Clapp, Bill To-

bias; Row 3: Pete Lilbach, Doug Schroeder.

\section{Pi Sigma Nu}




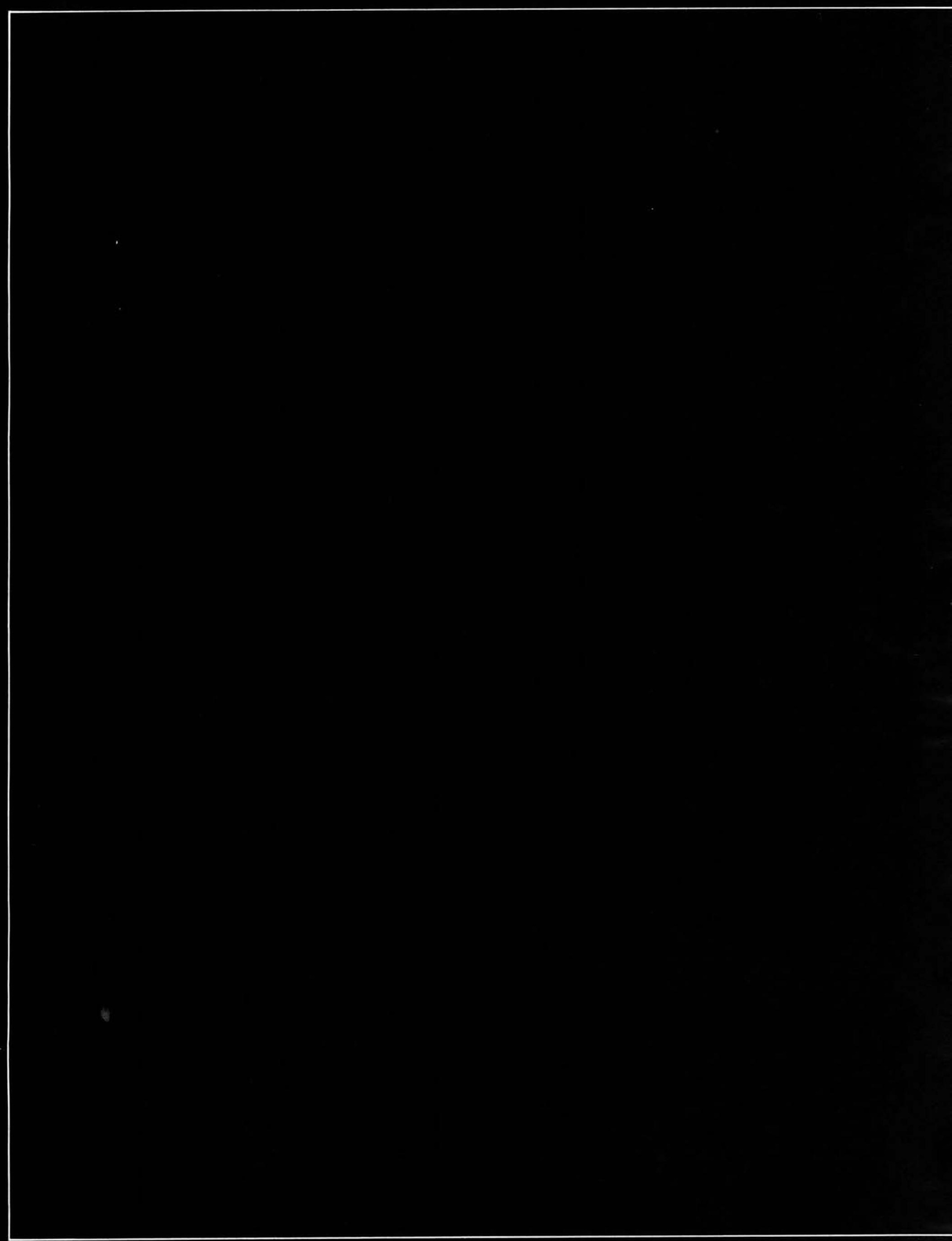


ADVERTISEMENTS 


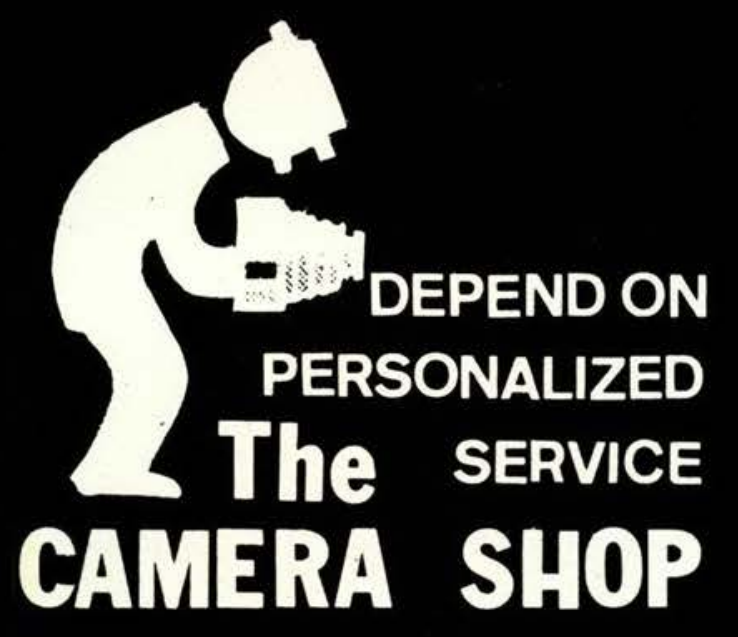

34 W. MAIN XENIA,OHIO

PHONE: 372-1469

\section{PARENT PATRONS}

Lloyd R. Carpenter

Wallace, Indiana

Dr. \& Mrs. Jack H. Cline

Rockbridge, Ohio

Mr. \& Mrs. Emery Cogan

Wauseon, Ohio

Mr. \& Mrs. S. M. Conrad

Akron, Ohio

Rev. \& Mrs. Alfred P. Conant

Iloilo City, Philippines

Mr. \& Mrs. Carl Cooper

Macedonia, Ohio

Mr. \& Mrs. Lester Cressman

Delphos, Ohio

Mr. \& Mrs. Robert P. Cuenin Amherst, Ohio

Rev. \& Mrs. Floyd A. Davis

Shawnee Mission, Kansas

Mr. \& Mrs. Raymond Davis

Chautauqua, New York

Harry Dilcher Sr.

Elba, New York

Richard D. Durham

Cedarville, Ohio

Mr. \& Mrs. Lyle P. Edwards

Bolivar, New York

Mr. \& Mrs. Dilas Edwards

Albian, Iowa

Rev. \& Mrs. Claude Eggleston

Ripley, New York

Fred T. Emerson

Richmond Hts, Ohio

Mr. \& Mrs. Richard Emerson

Carry, Pa.
Mr. \& Mrs. Jack Erickson

Hobart, Indiana

Mr. \& Mrs. James R. Flack

New Carlisle, Ohio

Mr. \& Mrs. W. A. Fleming, Sr. Lancaster, Ohio

Mr. \& Mrs. Byford C. Gibbons Alhambra, Illinois

Mr. \& Mrs. M. Gildan

Elyraia, Ohio

Ronald F. Glazier

Troy, Ohio

Mr. \& Mrs. W. L. Gons

Fostoria, Ohio

Mr. \& Mrs. Edward Greenwood

Cedarville, Ohio

Homer Hale

E. Alton, Illinois

Rev. \& Mrs. Charles Harrison

New Richmond, Ohio

Mr. \& Mrs. Don R. Harold

Cary, North Carolina

Wayne Heal

Bunker Hill, Illinois

James K. Hetrick

Tonawanda, New York

Mr. \& Mrs. Oliver K. Holden

Endicott, New York

Mr. \& Mrs. Arthur W. Holfield, Jr.

Washington, D.C.

Mr. \& Mrs. Thomas Holley

Twinsburg, Ohio

Gladys R. Horn

Lima, Ohio

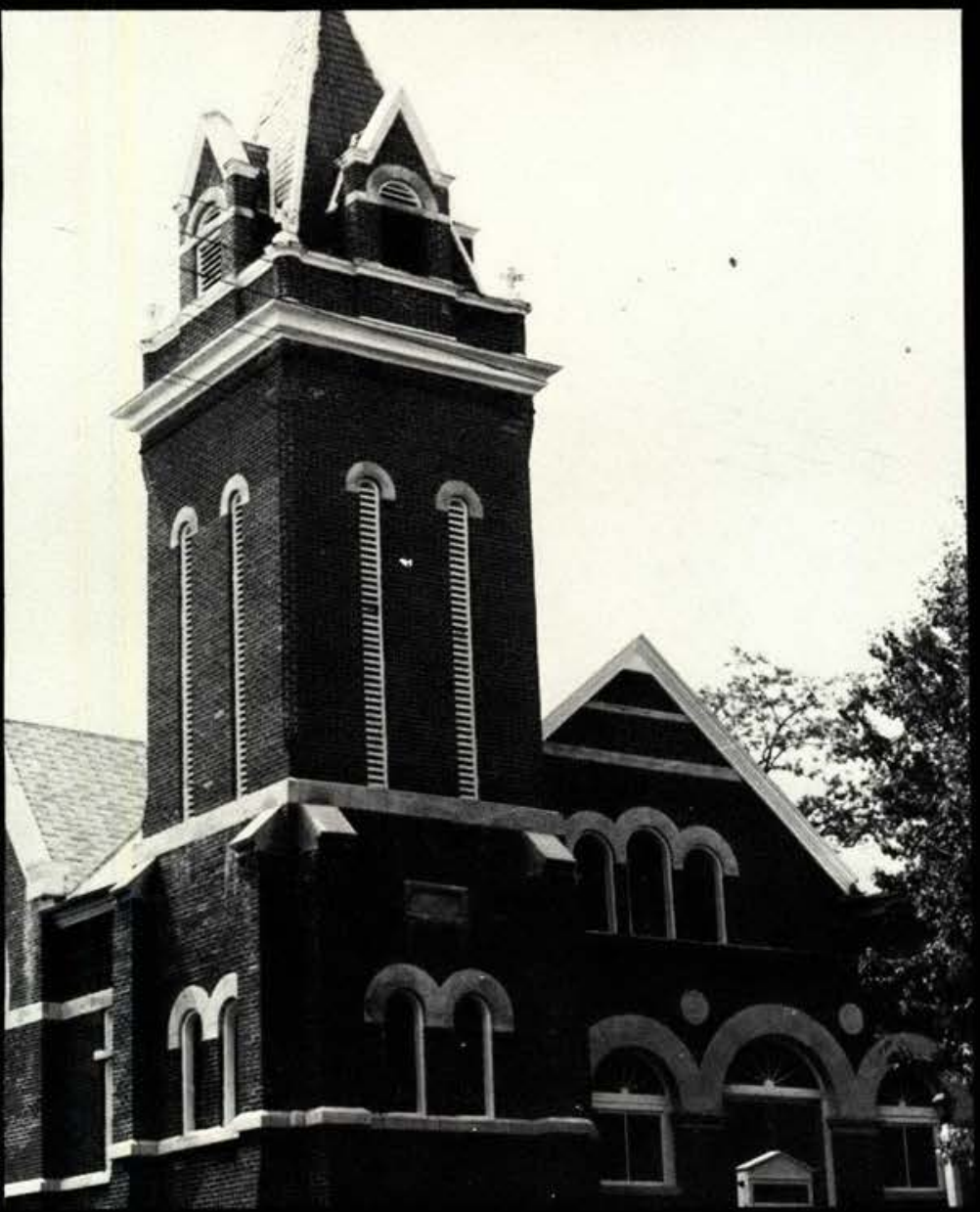

\section{GRACE BAPTIST CHURCH}

Cedarville, Ohio

William Broughton, Pastor

List of students who are members;

Rebecca Bittner

Lillian Burkhart

David Gidley

Janet Green

Tim Greenwood

Sarah Griffeth

Bill Hyatt

John Johnson

Merilee Johnson

Rhea Johnson

Terry L'Hommedieu
Phil McDonald

Richard McIntosh

Susan Moore

Nancy Ritchie

Jeff St. Clair

Michael Smith

Debbie Spencer

Carol Webber

David Webber

Patricia Werner

Linda M. White 


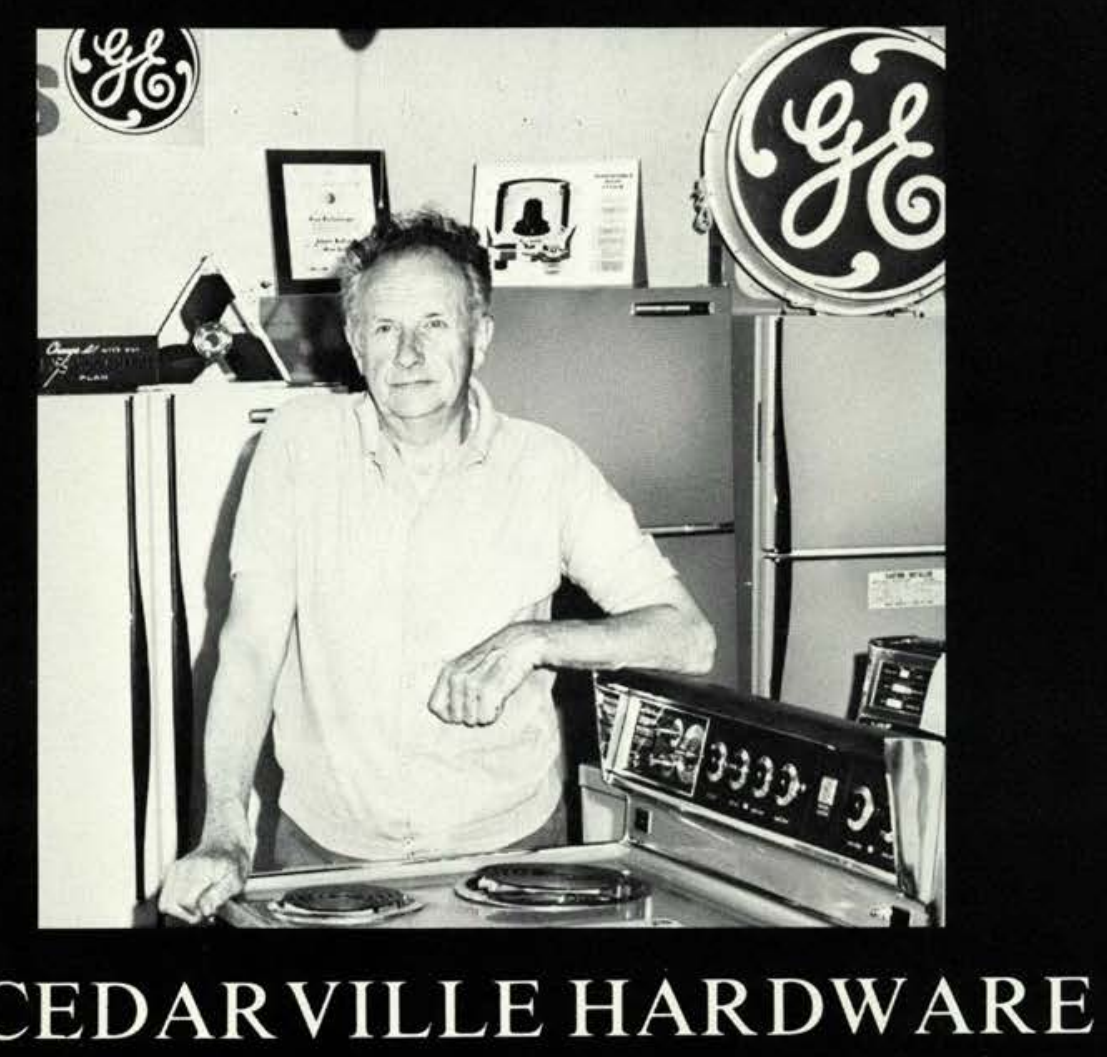

Hardware - Housewares - Gifts - G.E. Appliances

"For More Than A Quarter Century"

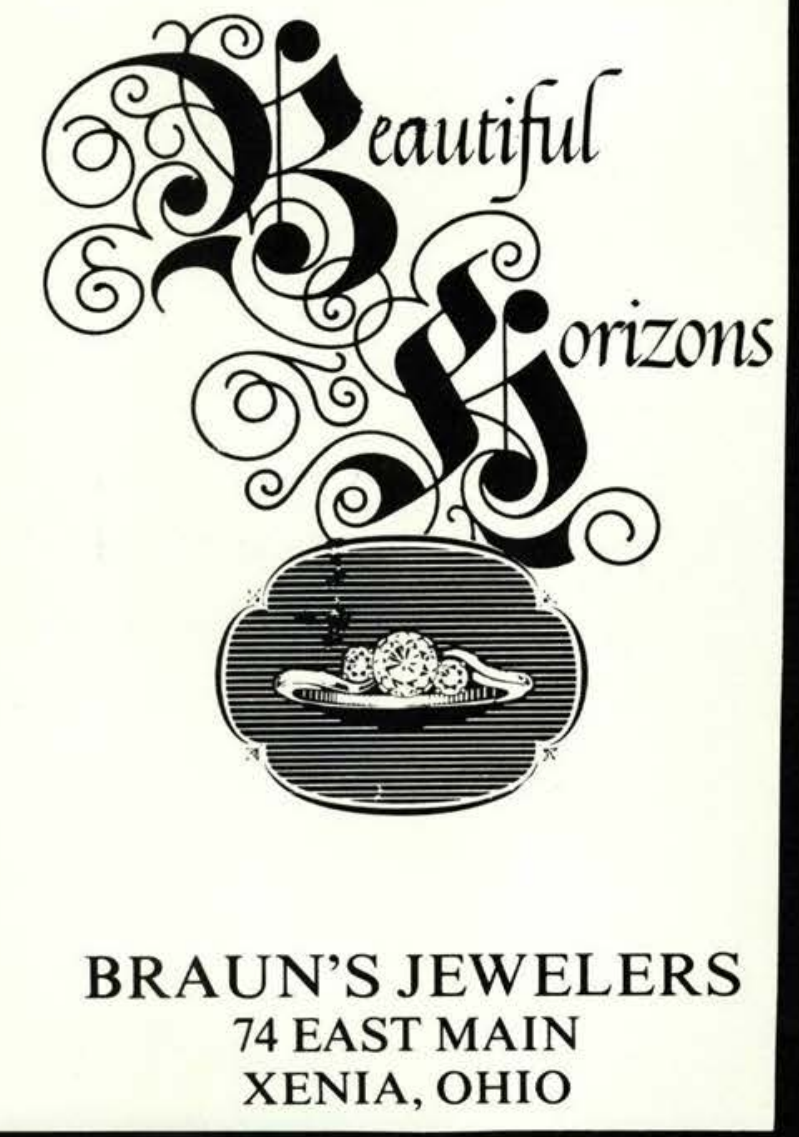

CHAPLIN CLEANERS

LAUNDR Y SER VICE

Cleaning - Shoe Repair

Phone - 766-3781

Cedarville, Ohio

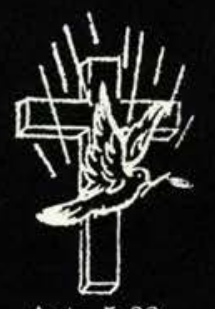

Acts $5: 32$

Rev. Garfield Judkins Pastor

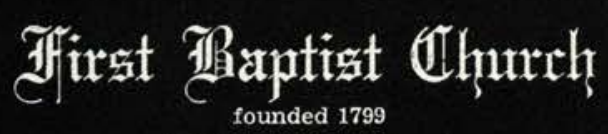
38 North Main Street Centerville, Ohio 45459 


\title{
CLINTONVILLE BAPTIST CHURCH
}

\author{
35 Oakland Park Avenue \\ Columbus, Ohio
}

George W. Hattenfield, Pastor

Founded on

Grounded in

Bounded by

\section{THE WORD OF GOD}

STUDENT AT CEDAR VILLE:

Jackie Cline

\section{GRANDVIEW PARK BAPTIST CHURCH}

1701 East 33rd. St.

Des Moines, Iowa

Harold Scholes, Pastor

CONGRATULATIONS

CLASS OF 1972
Congratulations Class Of 1972

from

FIRST

BAPTIST

CHURCH

Hobart, Indiana Charles R.

Wood,

Pastor

STUDENTS AT

CEDAR VILLE:
Village

Restaurant

"In the

Heart of

Cedarville",

Complete

Food Service

Phone -

766-5318 


\section{HADDON HEIGHTS BAPTIST CHURCH}

3rd And Station Avenues

Haddon Heights, New Jersey

Dr. K. W. Masteller, Pastor

STUDENTS AT CEDAR VILLE:

Jeff Kistler Dave Price Don Schill Charlie Sheppard Linda Walter

FIRST BAPTIST CHURCH

125 Grand Avenue

Wellington, Ohio

Charles W. Rugg, Pastor
BETHEL BAPTIST CHURCH

1704 Springdale Road

Cherry Hill, New Jersey

Dr. Carl E. Elgena, Pastor

"Your soul is our sole business"

\section{WHEELERSBURG BAPTIST CHURCH}

Gallia and South Streets

Wheelersburg, Ohio

Donald Grollimund, Pastor

STUDENTS AT CEDAR VILLE:

Vivian Dials Chrys Martin Bonnie Nolen 


\title{
EUCLID-NOTTINGHAM BAPTIST CHURCH
}

\author{
18901 Lake Shore Blvd. \\ Euclid, Ohio \\ Dr. Wilbur C. Rooke, Pastor \\ STUDENTS AT CEDAR VILLE \\ Pat Emerson Linda Hulsman Gale Richardson John Rooke Adria Soeder
}

\section{GRACE BAPTIST CHURCH}

23096 Center Ridge Rd.

Westlake, Ohio

Ralph O. Burns, Pastor

"Holding forth the Word of

Life ... Holding fast the

Word of Life"

STUDENTS AT CEDAR VILLE

Scott Campbell Alan Dunn

\section{FIRST BAPTIST CHURCH}

221 New Castle St.

Butler, Pa.

Russell R. Camp, Pastor

CONGRATULATIONS

CLASS OF 1972

\section{CRITERION}

Xenia, Ohio

Men's Clothing And

Furnishings

Varsity Town - Arrow McGregor - Palm Beach

\section{FIRST BAPTIST CHURCH} OF HASTINGS

800 Vermillion Street Hastings, Minnesota 


\section{CALVARY BAPTIST CHURCH}

\author{
Box 25
}

St. Charles, Iowa

Best Wishes to the

Class of 1972

\section{PARENT}

PATRONS

Pastor W. E. Abernathy

Columbus, Ohio

B. Dale Addleman

Hillsdale, Michigan

Rev. \& Mrs. Wayne K. Anderson

Monroe, Iowa

Mr. \& Mrs. Robert M. Austin

New Milford, New Jersey

Mr. \& Mrs. Paul R. Avery

Endwell, New York

Mr. \& Mrs. Steve P. Bachely Mansfield, Ohio

Mr. \& Mrs. R oy O. Barker

Rochester, New York

Mr. \& Mrs. Julius Bixel

Lima, Ohio

Rev. \& Mrs. Clinton W. Bonnell

Alton, Illinois

Donald Bradford

Coshocton, Ohio

Mr. \& Mrs. John Branon

Portsmouth, Ohio

Mr. \& Mrs. Duane C. Branning

Binghamton, New York

Mrs. Don C. Briggs

Caldwell, Ohio

Mrs. J. F. Brooks

Glen Burnie, Md.

Roland P. Buccialia

Marlton, New Jersey

Mrs. Opal Buckingham

Greenville, Ohio

Mr. \& Mrs. Carlyle Campbell

Indiana, $\mathrm{Pa}$.
CEDAR VILLE

FEED AND

GRAIN

Grain, Feed, Seed,

Coal, Salt, Fert-

ilizer, Builders'

Supplies

And

Fencing

CEDARVILLE, OHIO

Phone - 766-2021

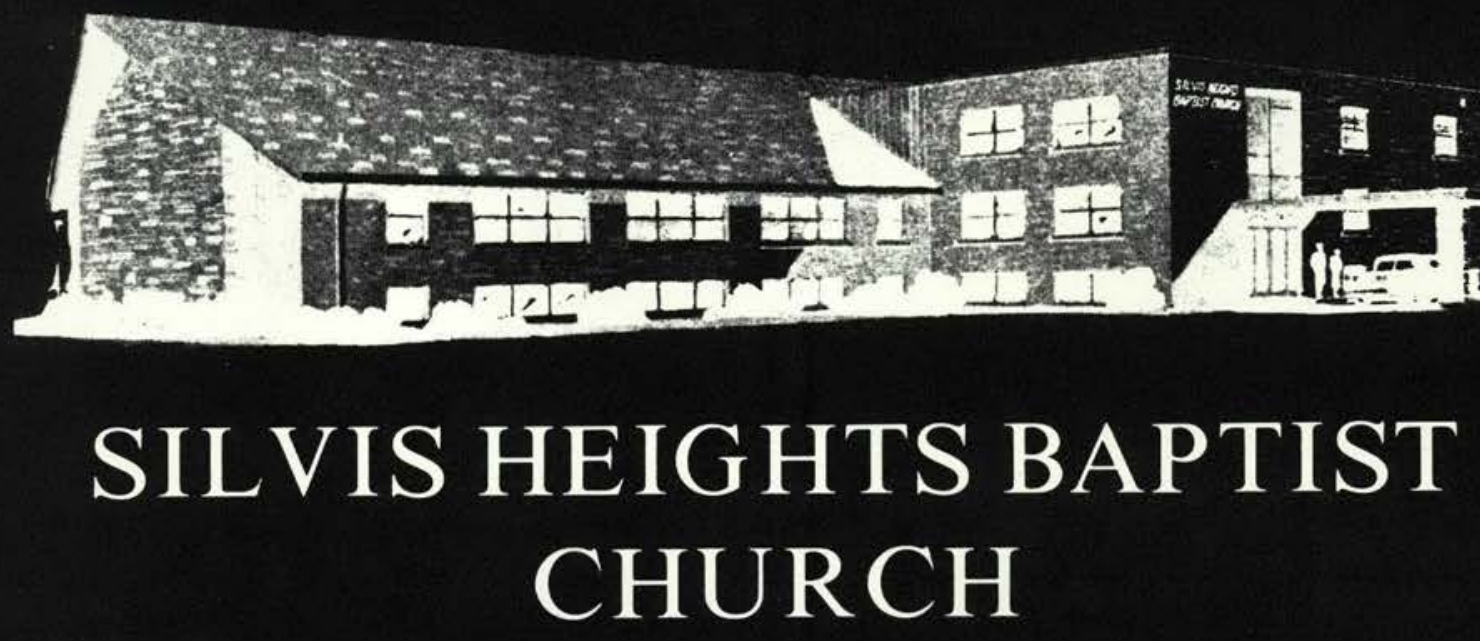

900 Middle Rd.

Silvis, Illinois

Orville W. Terry, Pastor Del Nicholls, Assoc. Pastor

STUDENTS AT CEDAR VILLE:

Becki Chandes
Robert Ewing

Fred "Bud" Laird 


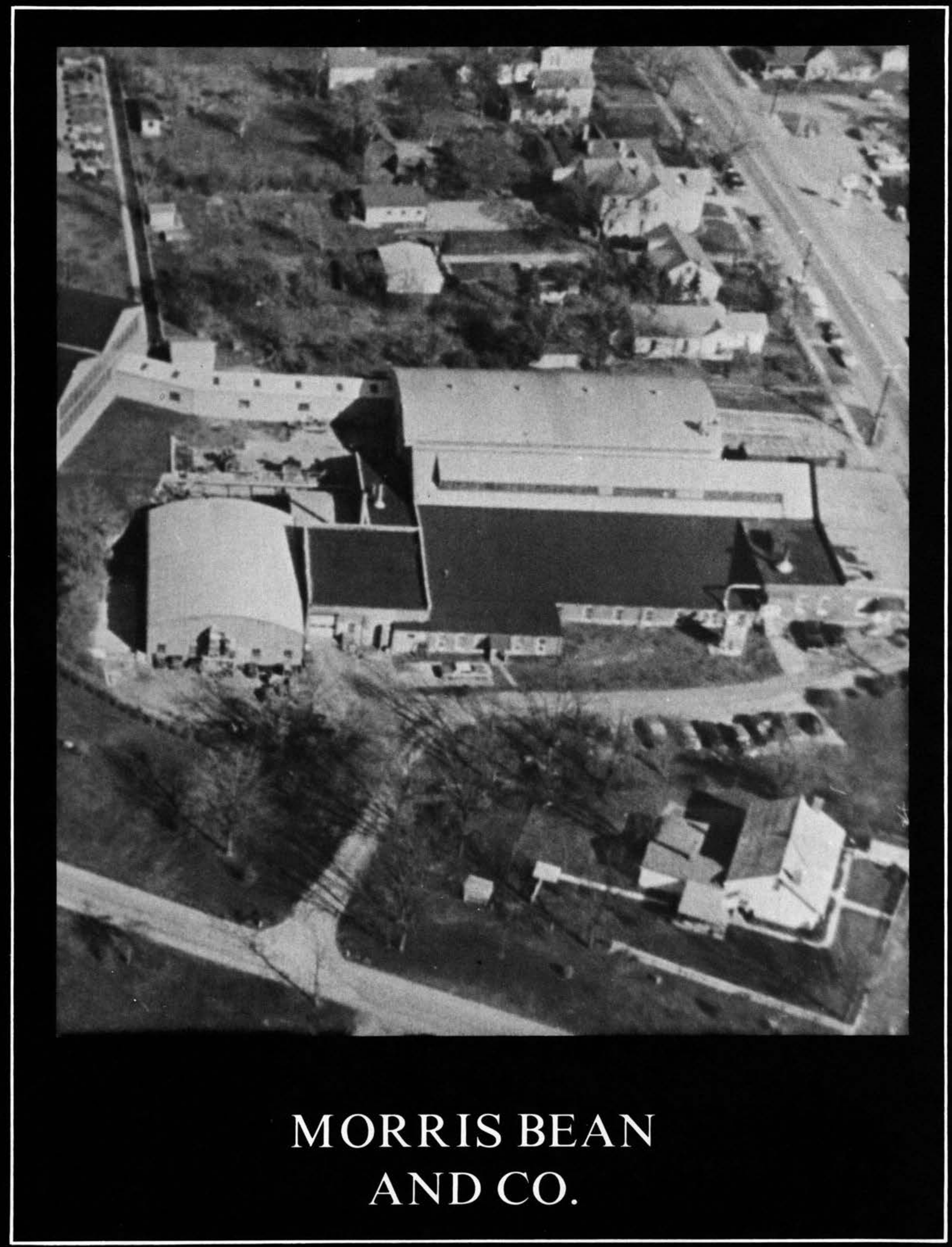




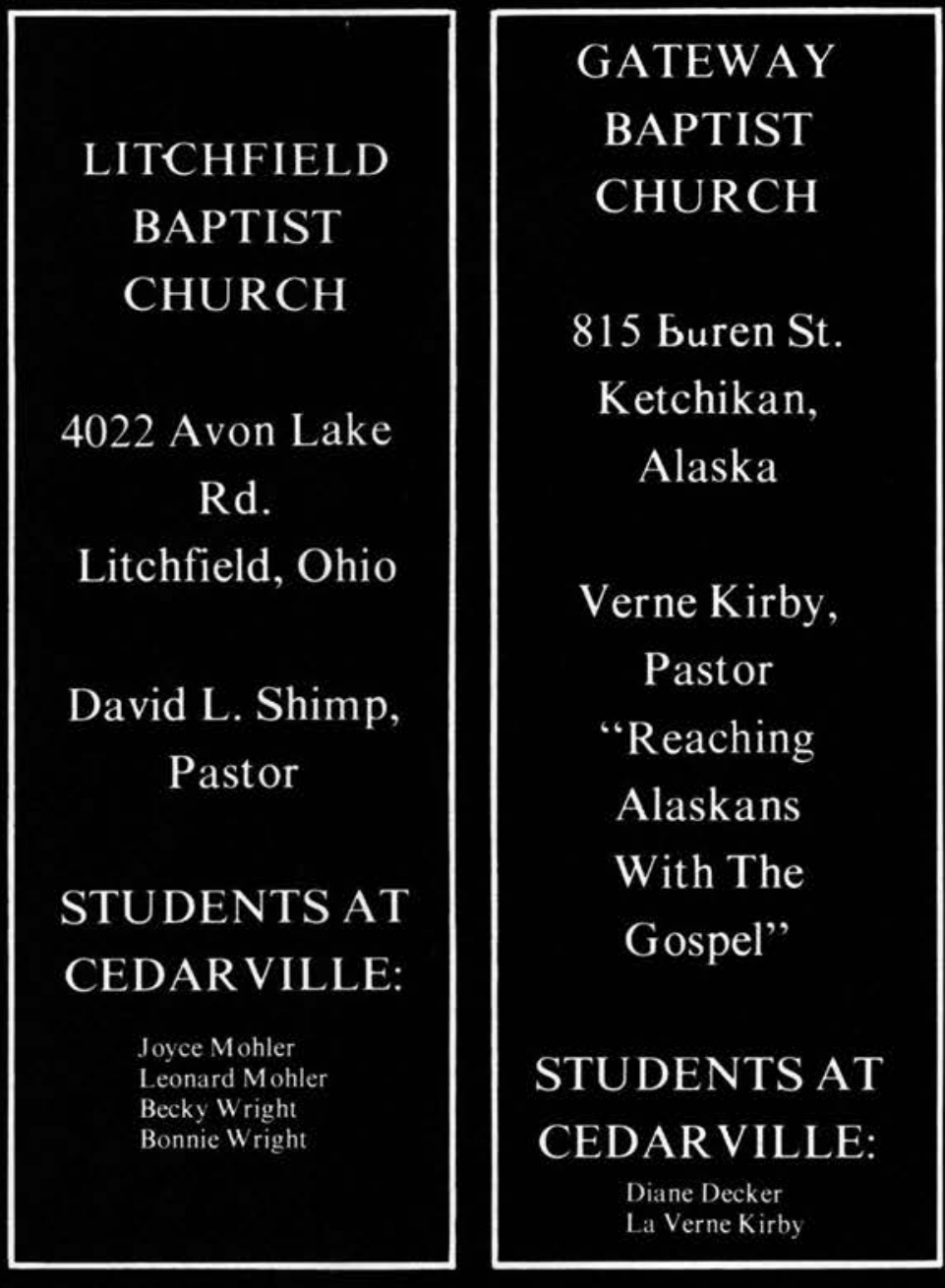

\section{CALVAR Y BAPTIST CHURCH}

South 6th St. at Race Ave.

Byesville, Ohio

H. P. House, Pastor

"Presenting the Unchanging

Word of God to an

Ever-changing World

$$
\text { of Men" }
$$

STUDENTS AT CEDAR VILLE:

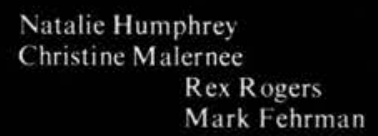

Natalie Humphrey

Christine Malernee

Rex Rogers

Mark Fehrman

SER VICES:

Sunday School. 9:30 A.M.

Worship. 10:30 A.M

Young People. 6:15 P.M.

Evening Service, 7:30 P.M

Bible Study And Prayer

Wednesday Evening. 7:30 P.M 


\section{Congratulations Class of 1972}

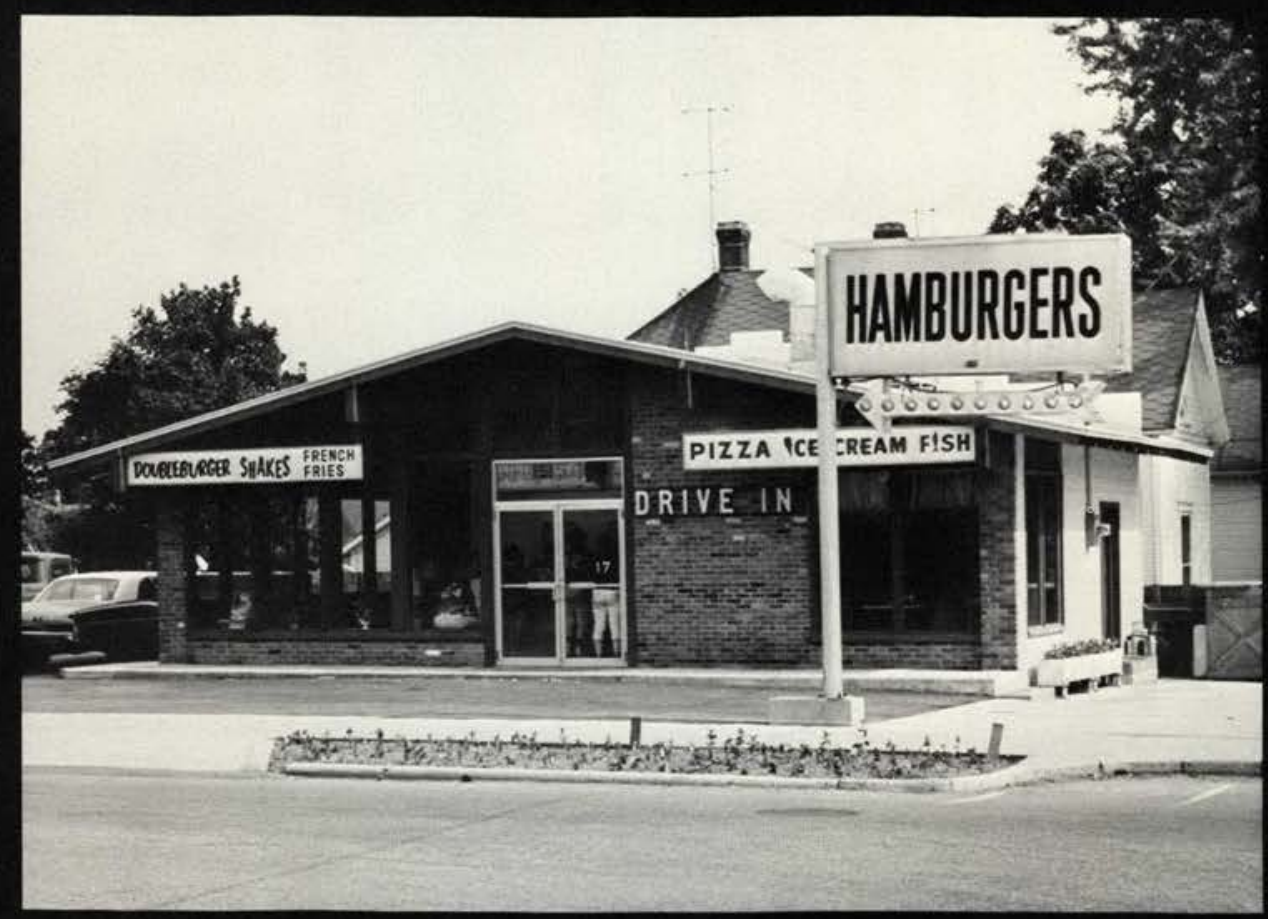

Little Joe's In Cedarville - just for you

\section{PARENT PATRONS}

Charles L. Hunter

Mentone, Indiana

D. D. Humphrey

Byesville, Ohio

Mr. \& Mrs. Sheldon Jackson

Carroll, Ohio

Mr. \& Mrs. Russell W. Jenkins, Jr.

McLean, Virginia

Robert Jeffords

Portage, Indiana

- James Jewell

Elyria, Ohio

Mr. \& Mrs. Robert E. Jones

Wellman, Iowa

Mr. \& Mrs. William E. Jones

Racine, Wisconsin

Dillon Karsian

Hackensack, New Jersey

Myrtle C. Keithlive

Johnson City, New York

Mr. \& Mrs. Neil Kennedy

Camillus, New York

Mr. \& Mrs. Herbert Kemble

Elyria, Ohio

Mr. \& Mrs. William G. Kesler

Olney, Illinois

Mr. \& Mrs. Everett Kern

Waterloo, Iowa

Rev. \& Mrs. Verne Kirby

Ketchikan, Alaska

H. L. Lewright, Jr.

Eagle Grove, lowa

Mr. \& Mrs. James E. Lough

Berea, Ohio
Mr. \& Mrs. Vincent Mahl

La Grange, Ohio

Carlton McCracken

Curwensville, Pa.

Mr. \& Mrs. Emery Moore, Jr.

Elyria, Ohio

Mr. \& Mrs. Russell Moon

Freeport, New York

Wesley R. Moster

Wawatosa, Wisconsin

Mr. \& Mrs. Leonard Muggleworth

John B. Mulder

Columbia, Missouri

Mr. \& Mrs. Richard E. Muntis, Sr. Lima, Ohio

Mr. \& Mrs. Charles McMurtry

Pittsburgh, $\mathrm{Pa}$.

Mr. \& Mrs. Arnold Nauman

Otselic, New York

Mrs. Verta Ness

Mishawaka, Indiana

Mr. \& Mrs. Orville Nolen

Wheelersburg, Ohio

Manuel G. Pereira

Lake Ronkomkoma, New York

Mr. \& Mrs. Hallie Phelps

Lorain, Ohio

Mr. \& Mrs. Andrew Profant Parma, Ohio

Mr. \& Mrs. Frank Railsback

Olmstead Falls, Ohio

Mr. \& Mrs. M. H. Ransbottom

Pittsburgh, Pa.
Willingboro, New Jersey

\section{PARENT PATRONS}

\section{John D. Reese}

Lebanon, Ohic

Mr. \& Mrs. Maurice Reynolds New Philadelphia, Ohio

Ralph Richardson

Euclid, Ohio

Harold Refeuberich

Corry, Pa.

Mr. \& Mrs. Olin B. Rodgers Cuyahoga Falls, Ohio

Mr. \& Mrs. Lad Roderiguez Gary, Indiana

Mr. \& Mrs. Ernest B. Rogers

Byesville, Ohio

Harry H. Russell, Jr.

East Brunswick, New Jersey

Mr. \& Mrs. Herman C. Salomon

Hamburg, New York

Mr. \& Mrs. G. A. Saunders

Port Jervis, New York

Mr. \& Mrs. Lawrence Seigneur

Stryker, Ohio

Richard Selfridge

Elyria, Ohio

Dr. \& Mrs. Jack Scott

Clifton, Ohio

Mr. \& Mrs. W. N. Schill

Haddon Heights, New Jersey

Eric O. Schulz

Milwaukee, Wisconsin

Mr. \& Mrs. Richard Schutte

Quincy, Illinois

Earle B. Severs

Hamilton Square, New Jersey
Mr. \& Mrs. Francis Shank

New Madison, Ohio

Mr. \& Mrs. Lloyd E. Shaw Medina, Ohio

Mr. \& Mrs. William Shaw

Xenia, Ohio

Mr. \& Mrs. Donald Shawver

Lorain, Ohio

Mr. R. Gary Sheppard

Haddon Heights, New Jersey

Mr. \& Mrs. William Sims

Waterloo, Iowa

Mrs. Carl H. Smith

Findlay, Ohio

Mr. \& Mrs. Jewell Smith

Dearborn Heights, Michigan

Mr. \& Mrs. William O. Southwell

Bay City, Michigan

William S. Stephenson

Grundy Center, lowa

Mr. \& Mrs. George Strawn

Maryland Heights, Missouri

Mr. \& Mrs. Thomas Syphers Avon, Ohio

Mr. \& Mrs. Garnett E. Tate

Alton, Illinois

Rev. \& Mrs. C. L. True

La Habra, California

Pastor \& Mrs. Allan Vine

Arcanum, Ohio

Hiram J. Walter

Westmont, New Jersey

Rev. \& Mrs. Walter Warfield

Bloomington, Illinois 


\section{PARENT}

\section{PATRONS}

Raymond Warwick

Hilliard, Ohio

Mr. \& Mrs. Sam Watson

Mishawaka, Indiana

Paul L. Wheeler

Huntington. West Va.

Gail \& Elnora White

Springfield, Ohio

Mr. \& Mrs. Robert White

Harvey, Illinois

Mr. \& Mrs. Melvin Wigand

Marlton, New Jersey

Mr. \& Mrs. Charles W. Williams

Nebraska City, Nebraska

Mr. \& Mrs. H. M. Wineberg

DuBois, Pa.

Gordon Wimer

Cedarville, Ohio

Russell J. Wolfe

Farmingdale, New Jersey

Mr. \& Mrs. R. A. Wolfe

Dublin. Ohio

Mr. \& Mrs. Arthur M. Wood

Kokomo, Indiana

Mr. \& Mrs. Gordon Wood

Curwensville, $\mathrm{Pa}$.

Mrs. Marvel Young

Springfield, Ohio

Mr. \& Mrs. Claude W. Young

Bloomville, Ohio

Cedar-Cliff Beauty Salon

Cedarville Farm Impliment

The 1972 Miracle staff

would like to express their

thanks to Dr. Baumann and

Mr. Charles Miller for all

their patience and assistance.

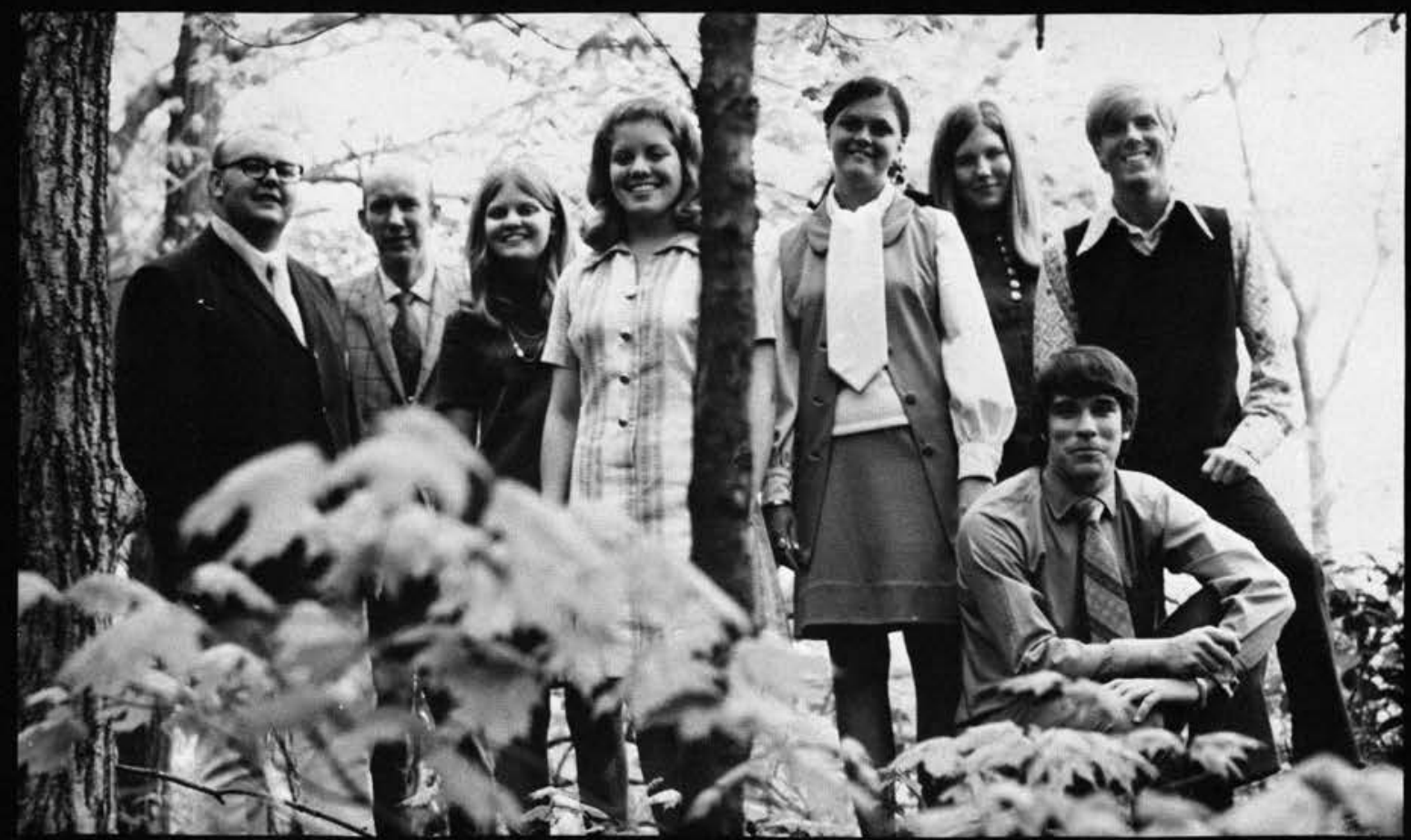




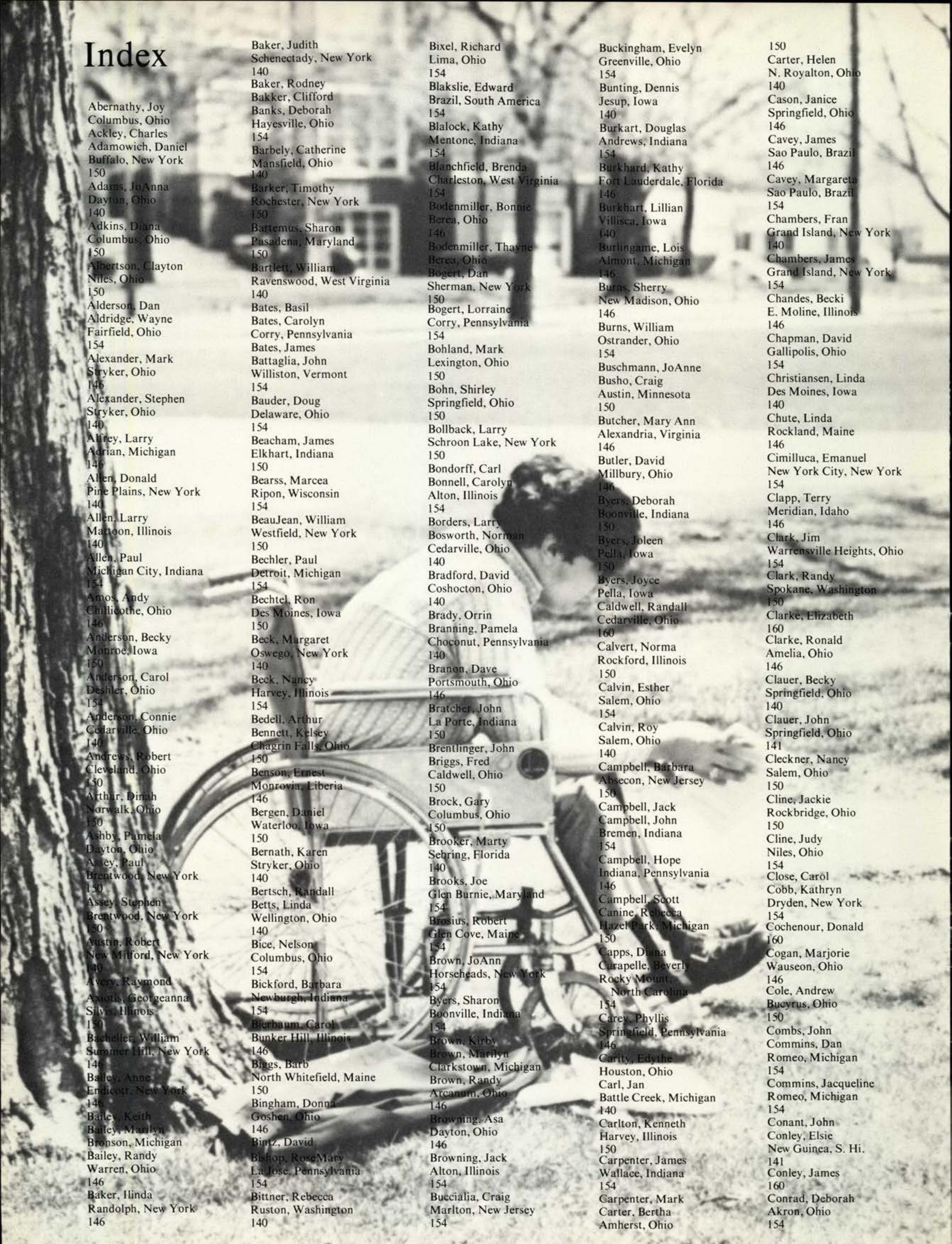




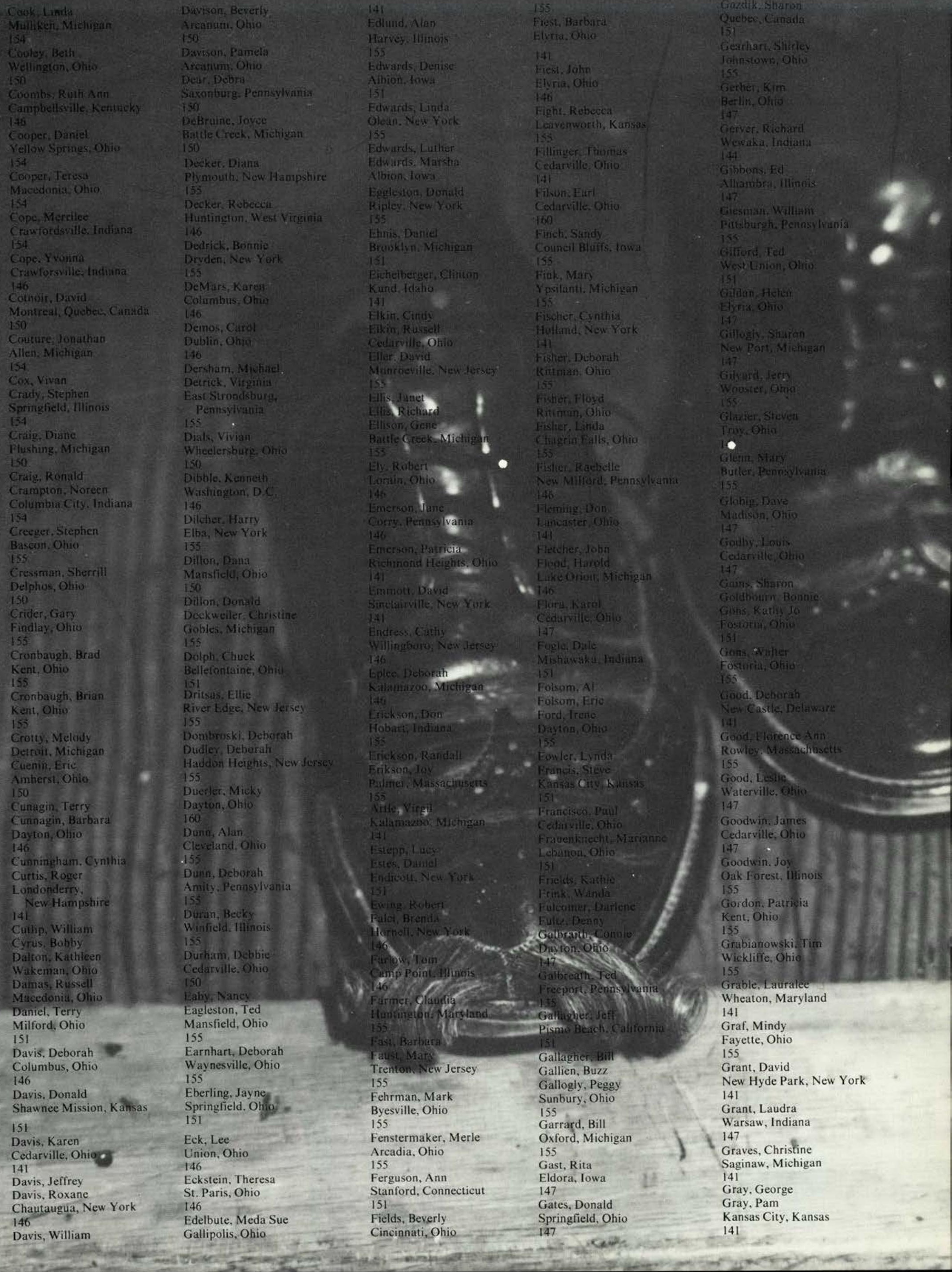




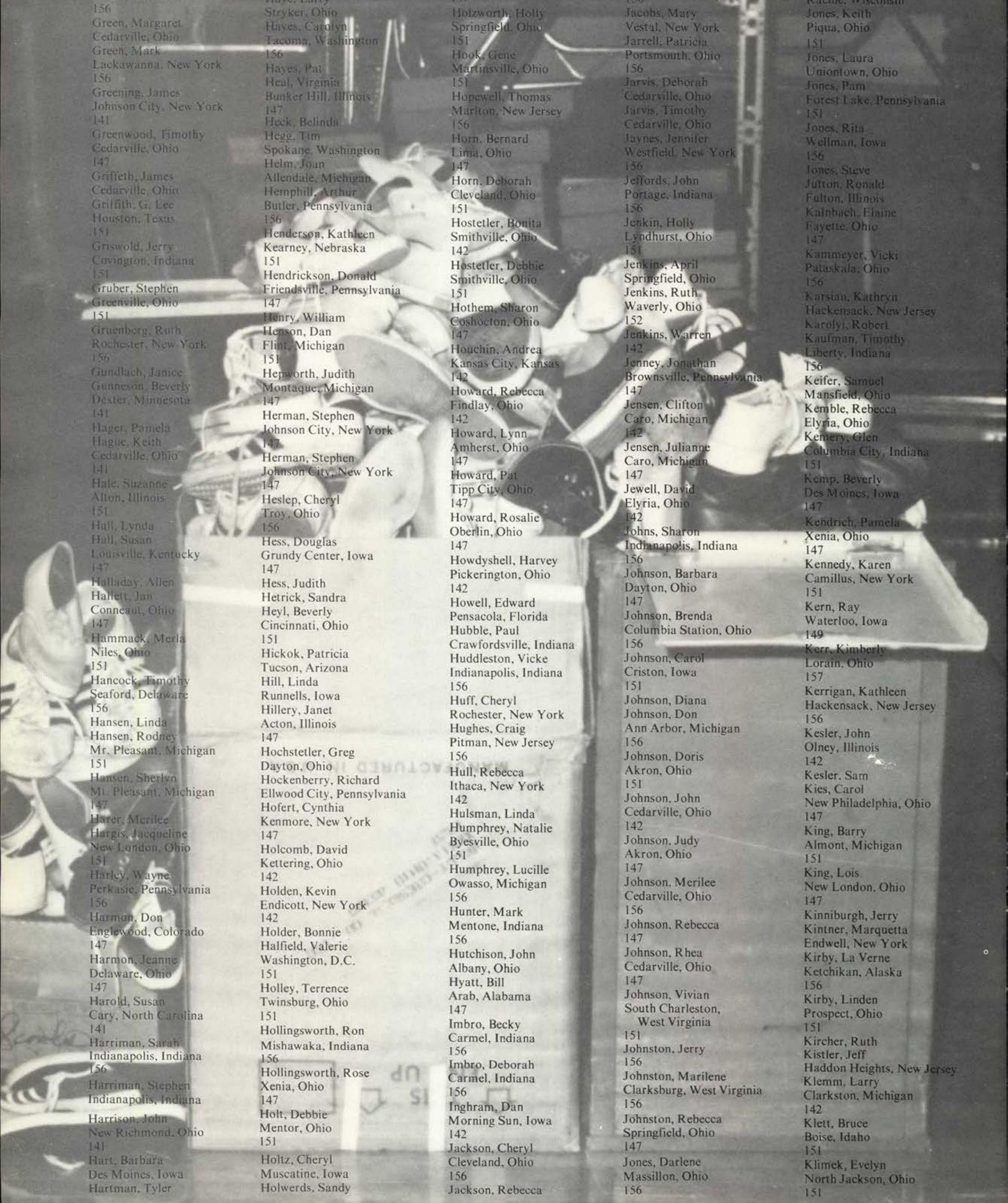


Kline, Janice

Cedarville, Ohio

142

Kline. Tim

Cedarville, Ohio 142

Klomparens, Cheryl

Grand Rapids, Michigan

Klutz, James

Knight, Arlene

Austin, Minnesota

147

Knowles, Tom

Milford, Michigan

Kohns, Marjorie

Fremont, Michigan

156

Konya, Alex

Maple Heights, Ohio

152

Kovacik, Thomas

Johnson City, New York

Kunz, Becky

Dayton, Ohio

156

Krueger, Edwin

Kwak, Thomas

Liang, Emma

Flint, Michigan

156

Laird, Fred

Carbon Cliff, Illinois

142

Lake, Doris

Atlantic City, New York

Lakes, Victor

Cedarville, Ohio

Lamb, Rebecca

Lancaster, Ohio

156

Lambert, Carolyn

Rittman, Ohio

142

Lambert, Steven

Kettering, Ohio

156

Lantz, Steven

Indianapolis, Indiana

156

Lantz, Dawn

Large, Paul

Larrich, Dana

Wilmington, Ohio

Larson, Curtis

Cedarville, Ohio

Larson, Gwen

Grand Rapids, Michigan

156

Larson, Stephen

Allegan, Michigan

156

Lathrop, Susan

Downers Grove, Illinois

142

Layne, Nanci

Gallipolis, Ohio

152

Leapline, Leslie

Dunbar, Pennsylvania

156

Ledger. Bette Jo

Canton, Ohio

Lee, Timothy

Trenton, New Jersey

Le Fever, Linda

Rochester. Michigan

146

Lemaster, Charles

Cedarville, Ohio

152

Lemaster, Sally

Cedarville, Ohio

Leslie, Frank

Meshappen, Pennsylvania

142

Lewis, Darrell

148

Lewis. Jeffrey

Ithaca, New York

157
Lewright, John

Eagle Grove, Iowa

152

Lewright, Nancy

Eagle Grove, lowa

157

Ley, Cheryl

157 Enfield, Connecticut

L'Hommediet, Terry 152

Long Island, New York Mawhorter, Michael

Lillback, Peter Owasso, Michigan

$\begin{array}{ll}\text { Painesville. Ohio } & 152 \\ 152 & \text { Mays, Mike }\end{array}$

Linderman. Lorraine

Ischua, $\mathrm{X}$

148

Linger, Lind

Northfield, Ohic

142

Lippert, M

Lithgow Lind

Milwaukee. Wisconsin

157 -

Logsdon, Su

Beavercreek,

157

Long, Janet

Dayton, Ohio

152

Lonie, Darrell

148

Losier, Richar

Lough, Jeff

Berea, Ohio

142

Love, Diane

Enon, Ohio

143

Love, Joyce

Chillicothe, Ohio

MoCallister, Steve

Columbus, Ohio

McCarty. Diana

Canfield, Ohio

McCauley, Ruth

Milwaukee, W

157

McClish, Luis

Sharon, Pennsyly

McConkey, Charle

McCracken, Kathle

Curwensville, Pennsylvania

McDaniel, Davia

Fairborn, Ohio

McDaniel, R/chard

Athens, Ohio

Athens, Ohio
152
McDenild, R beder

St. Charles, Iowa

143

Miller, Roger

Allegan, Michigan

143

Miller, Marilyn

Miller, Sally

Chesapeake, Ohio

143

Miller, Samue

London, Ohio

Miller, Yontz

St. Charles, Iowa

148

Millikan, Steve

Bothell, Washington

152

Nitchell, Lynn

Marion, Ohio

Mitman, Cynthia

Plainfield, Indiana

Mitman, Lucy

Indianapolis, Indiana

157

Mogle, Anita

Mohler, Joyce

Liechfield, Ohio

Mohler Leonard

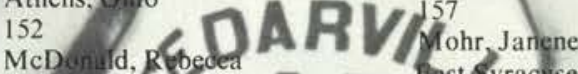

Evansvile, fullan Bast Syracuse, New York

157

McDonald, Phil

Cedartill, Ohio

McDornati, Thomas

Huntington, West Virginia

143

Lorette, Mel

Pensacola, Florida

157

Lowie, Darrell

Union Lake, Michigan

148

Lowstetter, Dennis

Greensburg, Pennsylvania

152

Luce, Donald

Montrose, Pennsylvania

Lucht, Gayle

Middlefield, Ohio

I57

(Lucius, Elizabeth

Luckett, John

Luketic, Barrett

Hammond, Indiana

152

Lutton, Nancy

Delta, Ohio

157

Lutton, Roberta

Delta, Ohio

148

Lysoonan, Boonchuay Bangkok, Thailand

157 143

Mahl, Robert

La Grange, Ohio

152

Mains. Carol

Wesley, lowa

157

Malernee, Christine

Byesville, Ohio

Mallinak, David

Lakewood, Ohio

Mally, Cynthia

157

Margraff, Pau

Zenia. Ohio

Marlowe, Catherine

Oxford, Michigan

143

Martin. Chry

Wheelersburg, Ohio

157
McFarland, Randy

Aberdeen, Ohio

157

McGhee David

McGhes: Richard

Alto

McGinen, Dave Moore, Susin

Bremen, Indiana $\quad 143 \quad 157$

Meln osh, Richard $\quad \begin{array}{ll}\text { Morrow, Beverly } \\ \text { Amherst, Ohio }\end{array}$

Cedur ville, Ohio

MeKanna, Don

ort Jennings, Ohio

âillen, Donna

Hastings, Minnestota

157

Mudder, homas

Hastings Minnestoa

148 .

Mugglewrofh, Dale

Willingsboro, New Jersey

157

Mulder, Karen

Columbia, Mississippi

157

Mummery, Sharon

Muntis, Richard

Lima, Ohio

Murray, Linda

Huntiogton Station,

Long Island, N.Y.

157

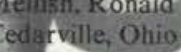

Messenger, Alice

ev field, New Y ork

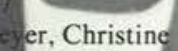

Teyers, Diane

ast Moline, Il

Spyngfield,
Miller, Lyle

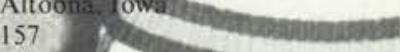

eyer, Christing
in

Nabring, Ranelle

Namy, Marleah

157

Nauman, Susan

Otselic, New York

148

Neeley, Sharon

Burghill, Ohio

148

Nelson, David

Santa Barbara, California

143

Nelson, Heanne

St. Louis, Mississippi

143 
Payne, John

Springfield, Ohio

157

Payne, Paulette

Cedarville, Ohio

Peacock, Susan

Grand Rapids, Michigan

157

Pearson, John

Warren, Indiana

157

Penegor, Bernice

Greenland, Michigan

Perdue, Carol

Pereira, John

Long Island, New York

143

Perkins, Marsha

Denver, Colorado

Perkins, Ralph

Denver, Colorado

Perkins, Roy

Denver, Colorado

Perry, Bruce

Tiffin, Ohio

143

Pestel, Beverly

Ladysmith, Wisconsin

143

Peters, Dave

Peterson, Gene

Cedarville, Ohio

148

Peterson, Janet

Colona, Illinois

148

Peterson, Karyn

Colona, Illinois

143

Phelps, Kathy

Phelps, Linda

Lorain, Ohio

143

Phillips, Harry

Lithopolis, Ohio

Poarch, Rebekah

Middletown, Ohio

148

Poole, Jacque

Crestline, Ohio

157

Portant. Richard

152

Porter, Glend

Springfield, Ohio

148

Porter, Tamara

Oneway, Michigan

143

Post, Rodney

Cedarville, Ohio

Potter, William

Alleghany. New York

152

Powley, Robert

Powley, Jeanette

take Orion, Michigan

Prater, Paula

Washington, D.C.

148

Pressnell, Alex

Price, Carol

Columbus, Ohio

157

Price, David

Haddon Heights, New Jersey

152

Price, Jame

Profant, Richard

Parma, Ohio

Pruden, Grace

Prudenville, Michigan

148

Pruden, John

Prudenville, Michiga

143
Pumpelly, Connie

Newark, Ohio

148

Pycraft, Bob

Avon Lake, Ohio

152

Quelle, Tom

Quick, Lianna

Radcliff, Paul

Caldwell, Ohio

144

Radcliffe, Daniel

Raike, Jody

Harrisburg, Ohio

152

Railsback, David

Cedarville, Ohio

Ransbottom, Ruth

Pittsburgh, Pennsylvania 144

Rathbun, Cynthia

Hamburg, New York

Read, Steve

Monticello, Indiana

148

Reeder, Susan

Youngstown, Ohio

Reeder, Thomas

Youngstown, Ohio

144

Reese, Sharon

Lebanon, Ohio

Rehn, Martha

Orangevale, California

157

Reilly, John

Cedarville, Ohio

Reising, Janet

Winterset, Iowa

158

Reno, Bill

Rentas, Cindy

Dayton, Ohio

Reynolds, Vicki

New Philadelphia, Ohio

148

Richardson, Gale

Euclid, Ohio

148

Richardson, Jame

Rifenberick, Holly

Corry, Pennsylvania

158

Rigg, Lynette

Dayton, Ohio

Riley, Patricia

Newark Valley, New York

Ritchie, Nancy

Cedarville, Ohio

158

Robb, Luann

Sherman, New York

R oberts, Betty

Roberts, Christine

Millersburg, Ohio

158

Roberts, Dennis

Bunkerhill, Illinois

148

Robison, Rodney

Kokomo, Indiana

158

Rocher, Shirley

Amberst, Ohio

144

Rodgers, Carl

Cuyahoga Falls, Ohio

148

Rodman, Lyle

Tower Hill, Illinois

144

avid

Greenlawn, New York

148

Rodriquez, Laura

Gary, Indiana

152

Rogers, Rex
Byesville, Ohio

152

Rogers, Sheila

Jerseyville, Illinois

152

Romaine, David

Gallipolis, Ohio

152

Romanow, Sally

Warren, Michigan

152

Rooke, John

Cedarville, Ohio

Rosa, James

Cedarville, Ohio

Rose, Randy

Eldora, Iowa

158

Rose, Richard

Rost, Jeffery

Oak Lawn, Illinois

158

Rothberg, Jagmes

Johnson City, New Yor

152

Rowe, Glenn

DeRuyter, New York

158

Ruby, Candace

Dayton, Ohio

144

Rufener, Christine

Willard, Ohio

148

Rufener, Ronald

Willard, Ohio

158

Ruffin, Charlotte

Rochester, Michigan

144

Russell, Priscilla

East Brunswick, New Jersey

148

Russell, Stephen

La Vale, Maryland New Madison, Oh

$158 \quad 148$

Ruschau, Madonna

Sagendorf, Sue

Edmore, Michigan

Sagraves, Cecil

Circleville, Ohio

Salomon, Fay

Hamburg. New York

152

Sampson, Robert

Crooked Creek, Perinsylvania

158

Samison, Deboral

Hallstead, Pennsylvania

152

Sarver, Eldon

Rose Hill, Iowa

148

Saunders, Susan

Port Javis, New York

Sawacki, Marsha

Jackson, Michigan

Schaffner, Dianne

Fayette. Ohio

158

Schaner, Cindi

Scharmann. Mario

Schroon Lake, New York

148

Schill, Don

Haddon Heights, New Jersey

Schilling, Dale

Novelty, Ohio

144

Schroeder, Douglas

Royal Oak, Michigan

Schroeder, Ronald

Royal Oak, Michigan

158

Schimkus, Richard

Schlener, Cynthia

Schneider, Anita

Rontoul, Illinois

Schopmeyer, Lloyd

Schultz, Esther

Milwaukee, Wisconsin

Schutte, Steve

Quincy, Illinois

152

Scott, Kathy

Clifton, Ohio

158

Clifton, Ohio

144

Seidler, Thomas

Detroit, Michigan

144

Seigneur, Reneé

Stryker, Ohio

152

Selden, Susan

Huntsburg, Ohio

152

Self, Joyce

Flint, Michigan

153

Selfridge, Marcene

Elyria, Ohio

144

Senseney, Martha 
$2 \frac{1}{2} x^{2}=\cos ^{6}$ 148 Talis Joanne \&

Dayton, $\mathrm{hi}$

158 Stallard

Meadville

Statom, id

Beech Gove

158

Steere, Da

Pontiac, II

158

Steinhoff,

Buffalo, N

158

Stemem $\mathrm{D}$

Fort Wayn

153

Stephens.

Hicksville,

158

Stevens, D

$\therefore$ Lindley, $\mathrm{N}$

153

Steyenson,

Baker, Mo

148 stevenson
Baker. Mi

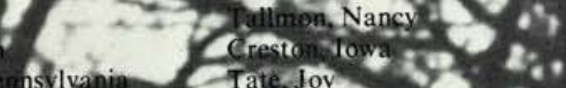
insylvanias - Tate, Joy
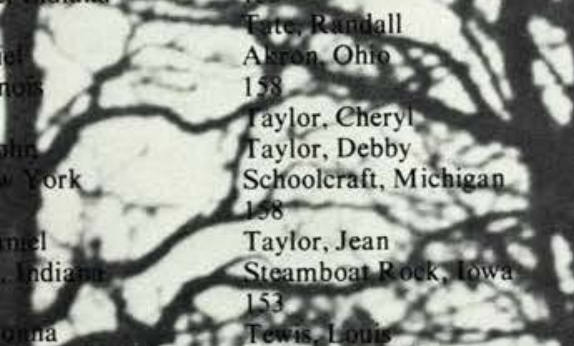

par 12 cedarville, obio

1. 140

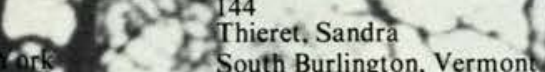

(1) -3158

Thomas, John
Columbus, Ohio
Thomas, Martin

rans 18.25

South Bend, Indiana

448

Sicphenson, Mark
Girundy Center, Iowa
Steward. Debbie

Steward, Debbie Thompson, Majorie

Omaha ${ }_{5}$ Nebraska

lanice
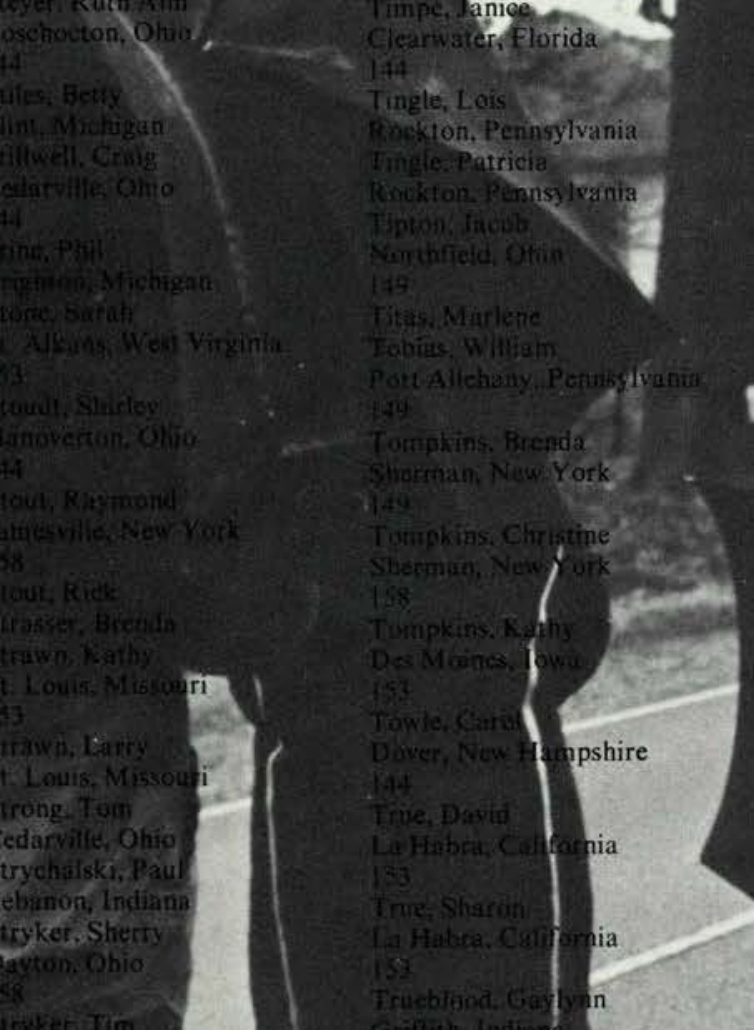

Flus
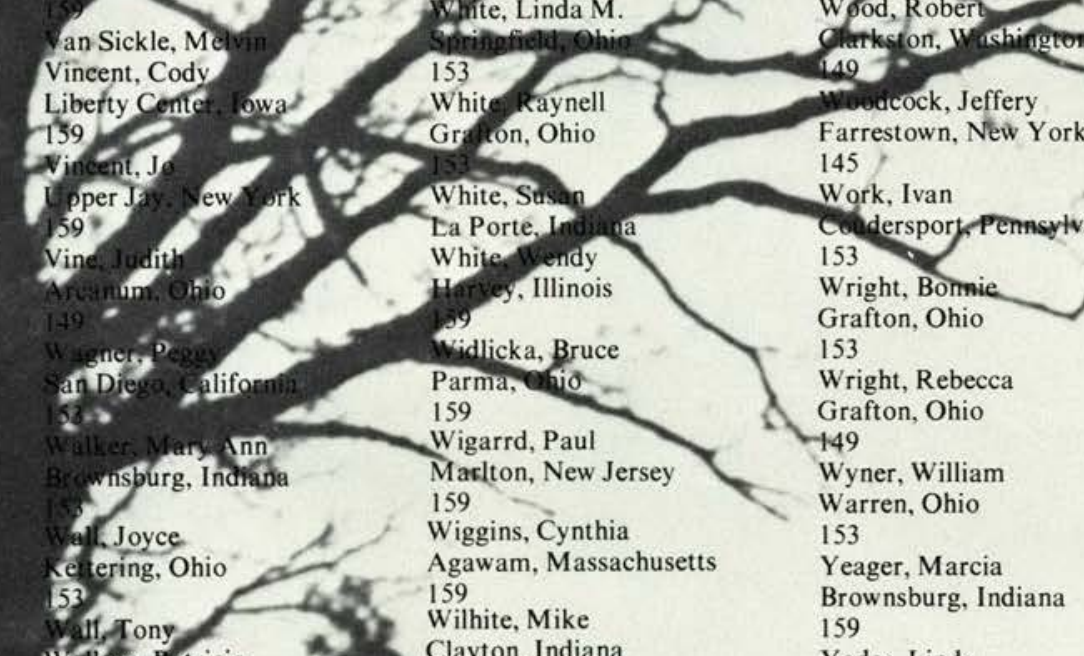
Wallice dentricia Clayton, Indiana Whiner, Rebecca, in 145

Jacksonumberida

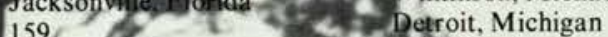

Walls, Elaine

Lima Ohio

Waler, Linda
yestmont, New Jersey

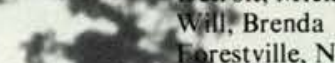

The Will, Brend

49 Nebraka City, Nebraska

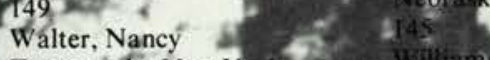

Tonawanda, New York E. Reynokssurg, Ohio

Walters, Randy
Springfield, Ohio

159 Lake Purk. Florida

Ward, Jerrie
East Cleveland, Ohio
Warficleld, Bette Bloonington, Illinois

w9-cyse?

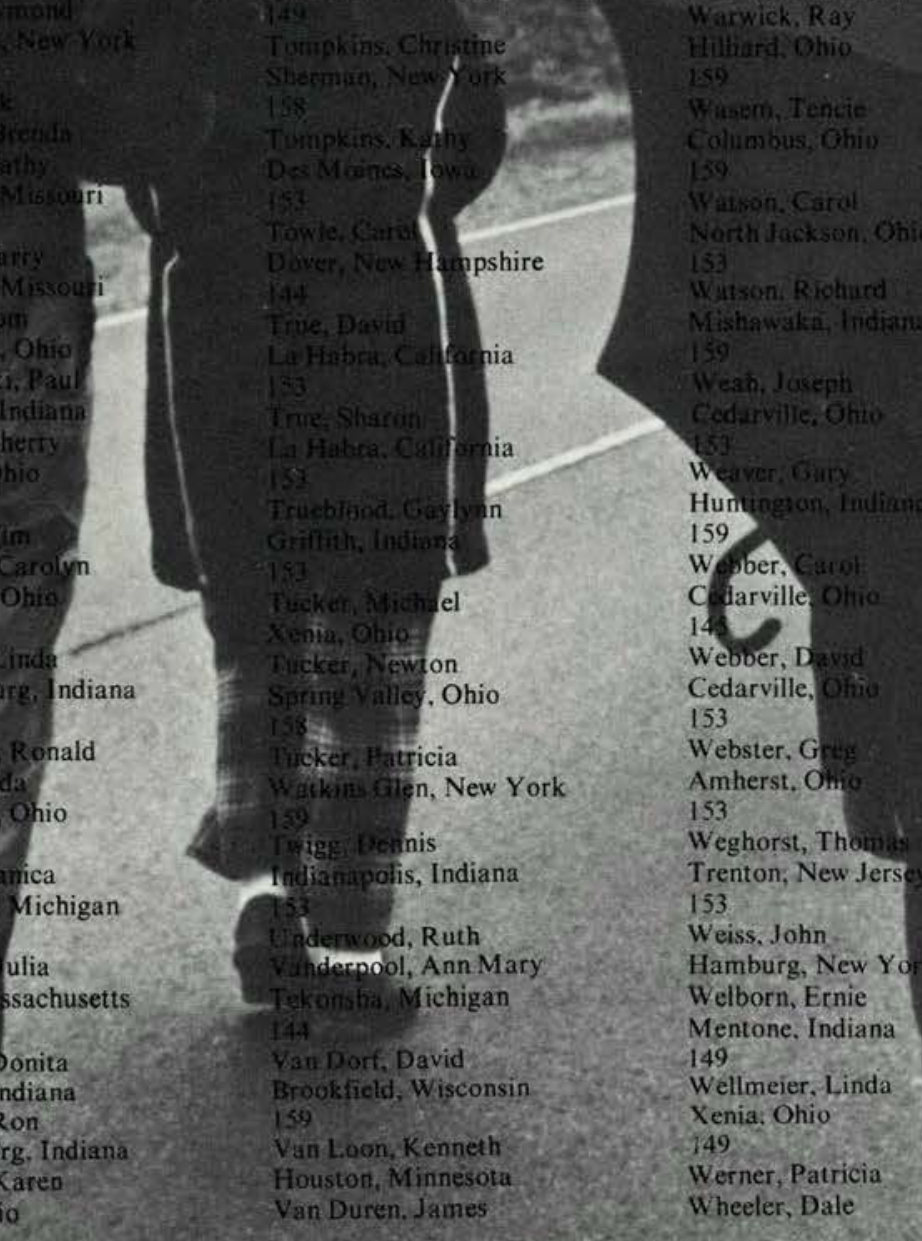

Yoder, Lind

Morgentown, Indiana

159

Young, Ellen

St. Paris, Ohio

Young, Janet

Waterloo, Iowa

153

Young, Karen

Mlbion, Indiana

A 59 ion, Indian

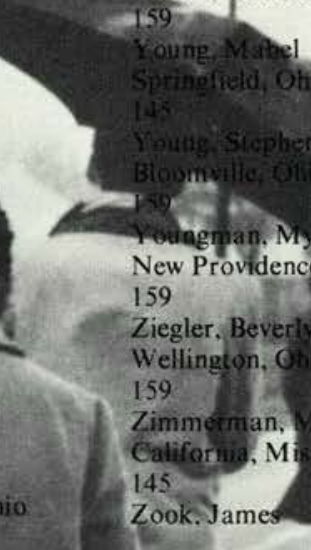



. 

